\title{
A Practical Approach to Semicarbazone and Hydrazone Derivatives via Imino-isocyanates
}

By

Keira Garland

Thesis submitted to the Faculty of Graduate and Postdoctoral Studies In partial fulfillment of the requirements for the

M.Sc. degree in the

Ottawa-Carleton institute

Faculty of Science

University of Ottawa

Candidate

Supervisor

Keira Garland

Dr. André M. Beauchemin

(C) Keira Garland, Ottawa, Canada, 2014 


\section{Abstract}

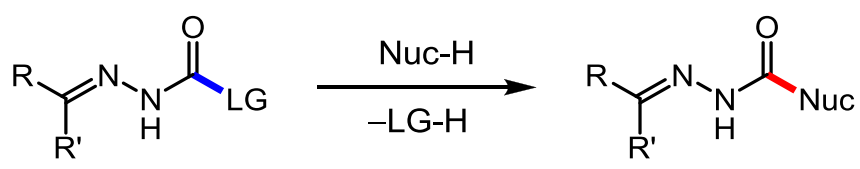

Isocyanates have a broad spectrum of uses and they are used in the production of many products including polyurethane polymers, coatings, adhesives, paints and foams. While isocyanates are widely studied and well represented in the literature, nitrogen substituted isocyanates are quite rare. Amino and imino-isocyanates are examples of nitrogen substituted isocyanates. Previous work within the group studied the reactivity of these intermediates in the alkene aminocarbonylation reaction, and used hydrazones and hydrazides as precursors of nitrogen substituted isocyanates. From there, a second reaction pathway was studied. This involved the reactivity of hydrazones with nucleophiles to develop a simple exchange reaction. In this work, the substitution reactivity involving imino-isocyanates will be presented. This will include the scope of nucleophiles and hydrazones as well as a discussion on the formation of the imino-isocyanates. This reactivity allows for the facile formation of a variety of hydrazones with the flexibility to start from common hydrazone precursors. 


\section{Acknowledgements}

I would like to first thank André Beauchemin for welcoming me into the group. I really appreciate the opportunity to be a part of such a great lab. I have gained so much in these past two years, both academically and personally. Much of this is thanks to your patience, support, advice, and enthusiasm for chemistry. In addition to the wealth of chemistry knowledge gained in this time, the experience has also allowed me to develop many meaningful friendships.

I have been able to work with and learn from so many great individuals. Shubin, Thanks for all the helpful lab tips and discussions, I enjoyed benching next to such a positive spirit. Colin, you never failed to brighten my day, thanks for being an awesome desk mate and sharing the grad school experience with me. Amanda, Thanks for being a great friend and always thinking of me. Our random bike ride for doughnuts, skate on the canal and walks home together were memorable. Sampada, thanks for your friendship, I enjoyed all the conversations and time we spent together, especially the numerous games of pool. Kaitlyn, I really enjoyed our time together as lab mates, your work ethic and kindness are contagious. JF, thanks for your willingness to help, sharing your enthusiasm for chemistry, making study sessions more enjoyable, being a great friend both at work and outside of the lab, and motivating me to work hard (and climb harder!). Frank, thanks for all the conversations we had both about work and the outdoors. Thanks for being a great mentor. Mel, thanks for being so welcoming when I first joined and always willing to help out and answer questions. Chris, thanks for your friendship and enjoyable discussions. Nic Guimond, thanks for helping make the lab a fun and

lively place. Bashir, thanks for being a great lab mate. Tom, thanks for your guidance and just being a great person to chat with. Wei, for answering my questions and helping with my chemistry. Nic Das Neves, our random end of the day discussions were enjoyable and often quite insightful. Lyanne, thanks for the fun conversations and contagious laughter. Didier, thanks for always having the best witty responses and making me feel better about my addition to reddit by comparison to yours. Pouyan, 
thanks for the kindness and friendship, as well as the enjoyable chats by the fume hood. Thanks to all the talented undergraduates that I had the pleasure of working with, Kashif, Charlotte, Valérie, Pat, Nimrat, Brittany, and Kyle.

A final thanks to Darren for the support and encouragement, as well as my parents for always being there to offer support and guidance. 


\section{Table of Contents}

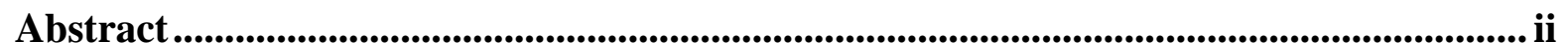

Acknowledgements........................................................................................................................... iii

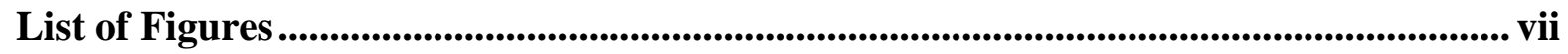

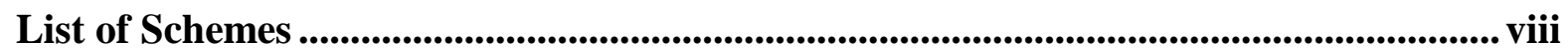

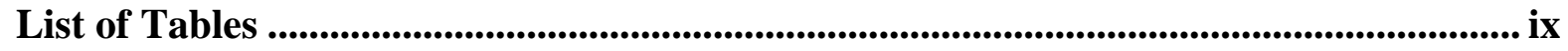

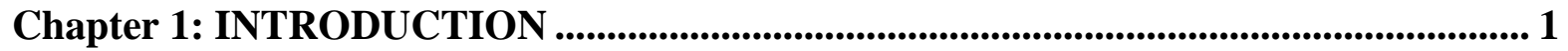

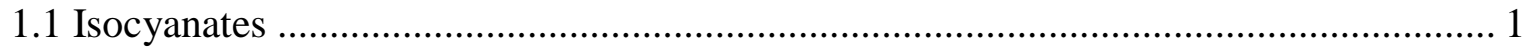

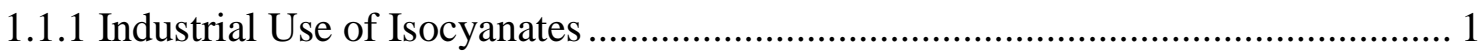

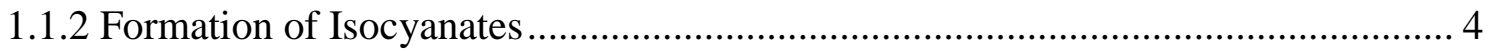

1.1.3 Examples of Isocyanate Reactivity .......................................................... 7

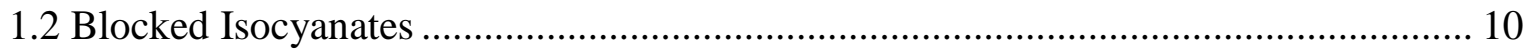

$1.3 \mathrm{~N}$-Substituted Isocyanates: Amino- and Imino-isocyanates .................................... 15

1.3 Leaving Group Exchange Reactivity - Imino-isocyanates ...................................... 21

1.4 Alkene Aminocarbonylation with Hydrazides and Hydrazones ............................... 27

1.5 Project Objectives for the Synthesis of Hydrazone Derivatives ................................ 30

Chapter 2: RESULTS AND DISCUSSION .......................................................................... 32

2.1: Previous work on leaving group exchange reactivity with imino-isocyanates .......... 32

2.2 Studies with tert-butyl 2-(2,4-dimethylpentan-3-ylidene)hydrazinecarboxylate (1a).. 33

2.2.1 Optimization of reaction conditions using thiols .......................................... 34

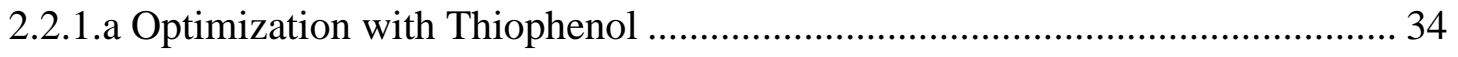

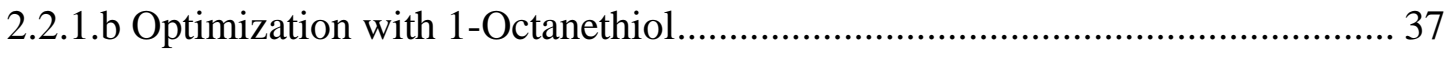

2.2.2 Nucleophile scope with tert-butanol as leaving group .................................... 38

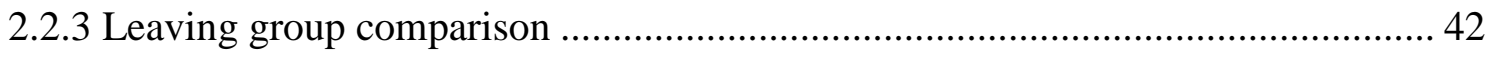

2.3 Mechanism of imino-isocyanate formation ........................................................ 46

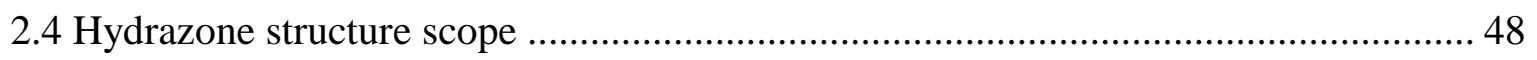

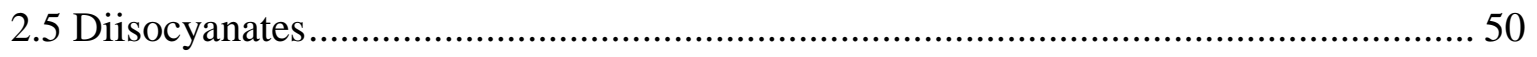

2.6 Other $N$-substituted isocyanates: amido-isocyanates ......................................... 53

2.7 Studies on the Alkylation of hydrazones and imino-isocyanate formation................ 55

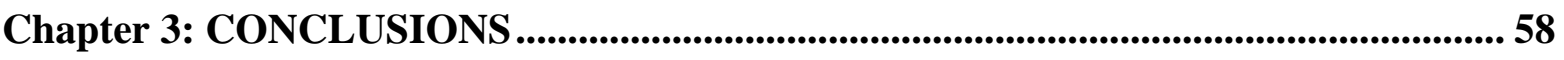

3.1 Project Summary and future work.................................................................. 58 


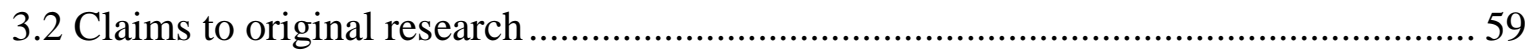

3.3 Publications and presentations from this work.................................................. 59

Chapter 4: EXPERIMENTAL ...................................................................................61

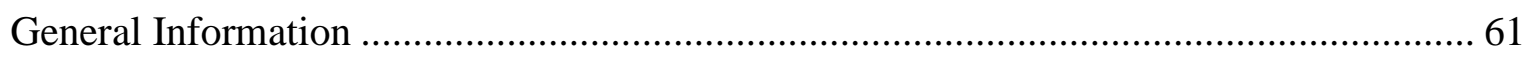

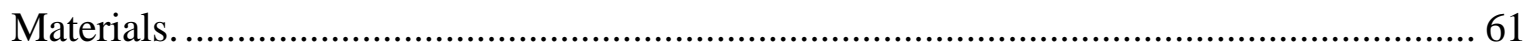

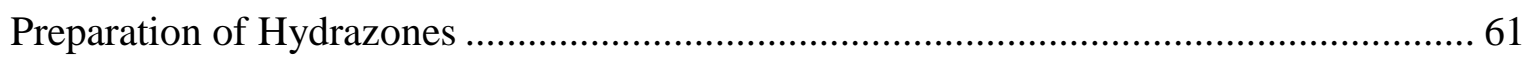

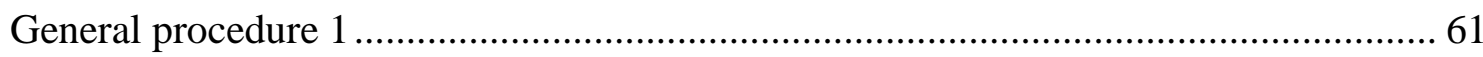

Preparation of Hydrazone Derivatives Using Leaving Group Exchange.......................... 65

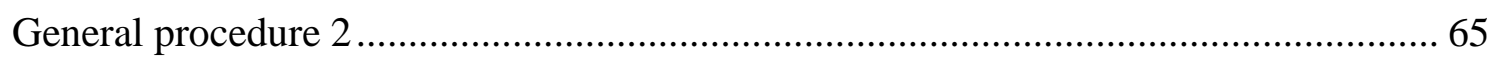

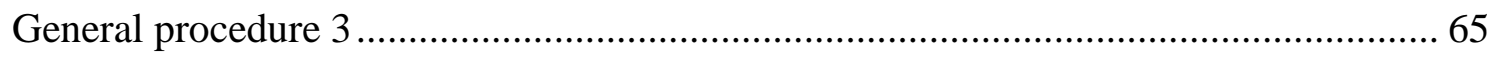

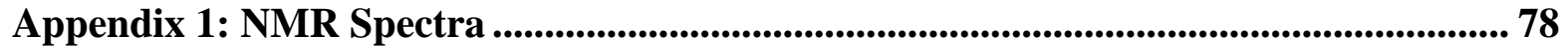




\section{List of Figures}

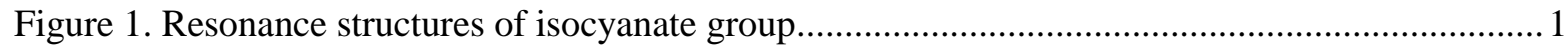

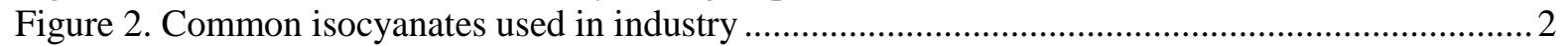

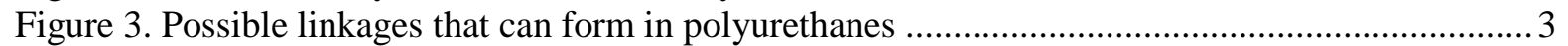

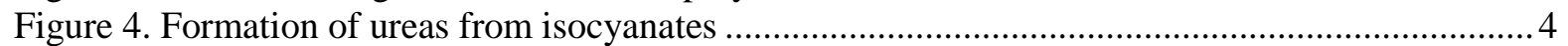

Figure 5. Mechanism for the generation of isocyanates from carbon monoxide using ruthenium

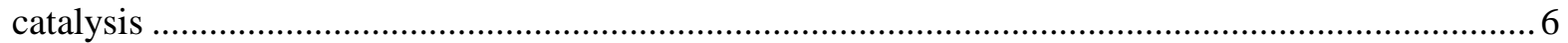

Figure 6. Formation of a blocked isocyanate using and an alcohol as a blocking agent to form a

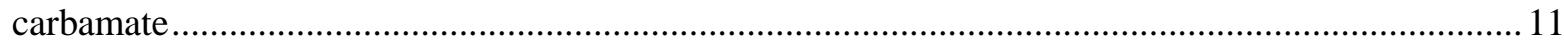

Figure 7: commonly used blocking agents for isocyanates ...................................................... 11

Figure 8: Formation of a blocked diisocyanate using MEKO as a blocking agent and upon heating the

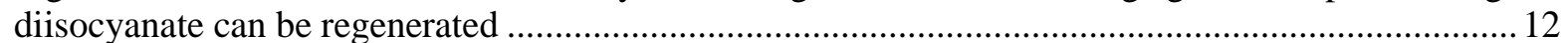

Figure 9: The pyrolysis of diethylmalonate blocked cyclohexylisocyanate ....................................... 13

Figure 10. Dimer, trimer, and polymer structures of isocyanates................................................ 15

Figure 11: Cleavage of cyclic aminimide to generate isocyanate and amino-isocyanate intermediates

Figure 12. Reaction of amino-isocyanate generated from cyclic aminimide with phenylacetylene ... 16 Figure 13: Generation of amino-isocyanate using photolysis and pyrolysis ................................... 19 Figure 14. Byproduct formation of the flash vacuum thermolysis of carbamoyl azide......................20 Figure 15. Generation of iminio-isocyanate through the thermolysis of an oxadiazoline...................20 Figure 16: Impact of nitrogen substitution on hydrolysis of aryl ureas .........................................24 Figure 17. Effect of nitrogen substitution on the methanolysis of aryl ureas .................................. 24 Figure 18. Addition-elimination pathway (top) and elimination-addition pathway with formation of

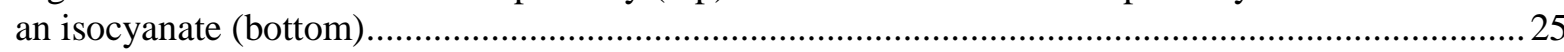
Figure 19: Nucleophilic substitution of various nucleophiles on aryl ureas with hindered disubstituted nitrogen. .25 Figure 20. Leaving group exchange reaction with $p$-bromophenylisocyanate to probe the generation of phenyl isocyanate 26 Figure 21: Comparison of distribution of products when trisubstituted urea and phenylisocyanate are

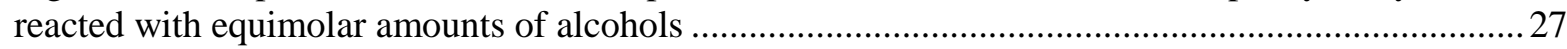

Figure 22. Intermolecular alkene amino-carbonylation using acyl hydrazones ...............................29

Figure 23: Room temperature reactivity with various nucleophiles and hydrazones ........................48

Figure 24. Leaving group exchange reaction using a variety of hydrazones and nucleophiles........... 49 Figure 25. Three common industrial di-isocyanates; toluene di-isocyanate, $m$-xylylene di-isocyanate, hexamethylene di-isocyanate 


\section{List of Schemes}

Scheme 1. Formation of a polyurethane using hexamethylene diisocyanate and ethanediol ............... 2

Scheme 2. Formation of $p$-nitrophenyl isocyanate from phosgene and $p$-nitroaniline ......................... 4

Scheme 3. Formation of isocyanate via nitrenes, using the Hofmann (Eq 3) and Curtius

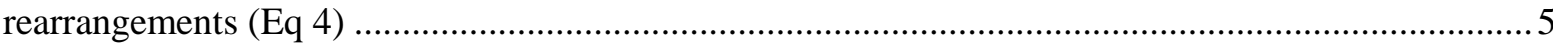

Scheme 4. Lossen rearrangement using hydroxamic acid to form isocyanates..................................6 6

Scheme 5. Formation of hindered amides employing Grignard reagents and isocyanates.................... 7

Scheme 6. Rhodium catalyzed cycloaddition developed by Rovis ................................................. 7

Scheme 7. Formation of vinylogous amides and bicyclic lactams from cycloaddition of isocyanates

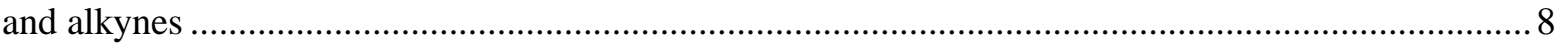

Scheme 8 . Pyrimidinone formation by rhodium catalyzed cyclization of isocyanate and $\alpha, \beta$ -

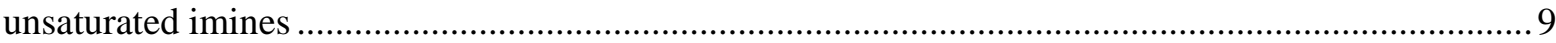

Scheme 9. Palladium coupling with phenyl chloride and sodium cyanate; formation of isocyanates

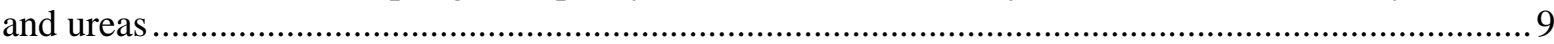

Scheme 10. Use of phenol as additive in formation of ureas coupling aryl chloride and sodium

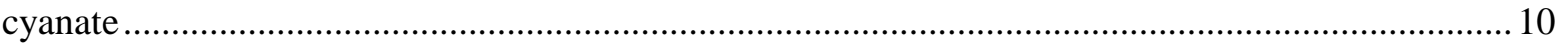

Scheme 11: Methyl isocyanate blocked with malonic ester .......................................................... 12

Scheme 12: Formation of amino-isocyanate using CDI and $N, N$-dimethyl hydrazine and resulting

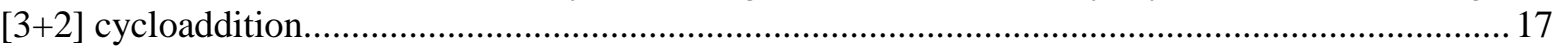

Scheme 13. Formation of amino-isocyanate via Curtius rearrangement ........................................ 18

Scheme 14. Formation of amino-isocyanate dimer from $N, N$-dimethyl ethylcarbazate using

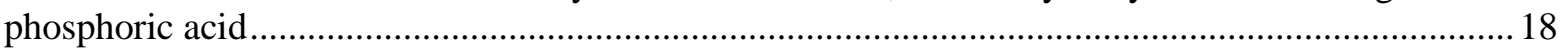

Scheme 15. Cycloaddition of diphenyl imino-isocyanate and phenyl isocyanate ............................. 21

Scheme 16: General reaction scheme for the leaving group (LG) substitution ............................... 21

Scheme 17. Leaving group exchange with aniline as nucleophile and ethanol as leaving group .......22 Scheme 18. Example of a substitution reaction using $p$-nitrophenol as leaving group and amino ester

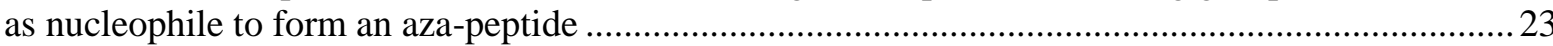

Scheme 19. Two possible pathways for the formation of phenyl isocyanate from hindered urea ......26

Scheme 20. Alkene amino-carbonylation of imino-isocyanate and phenylacetylene ........................28

Scheme 21: Intramolecular alkene amino-carbonylation with hydrazides ......................................28

Scheme 22. Synthesis of $t$-butyl hydrazone by condensation of $t$-butylcarbazate and diisopropyl

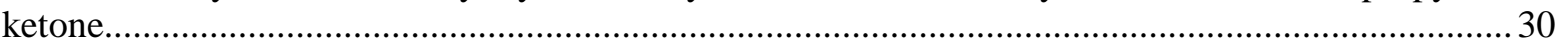

Scheme 23. Solvolysis of tert-butyl hydrazone with (1) diisopropyl amine and (2) thiophenol......... 31

Scheme 24: Formation of the imino-isocyanate via either a concerted (bottom) or step-wise

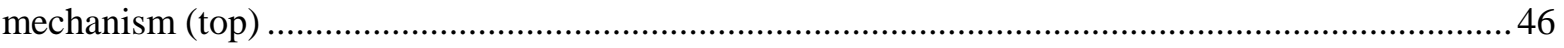

Scheme 25. Decomposition of phenylcarbazate via formation of an amino-isocyanate upon heating 50 


\section{List of Tables}

Table 1: Effect of Leaving Group on Intermolecular Alkene Aminocarbonylation........................... 30

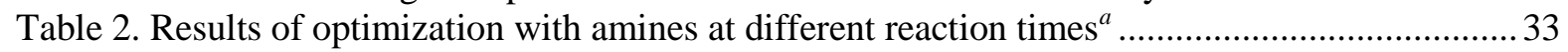

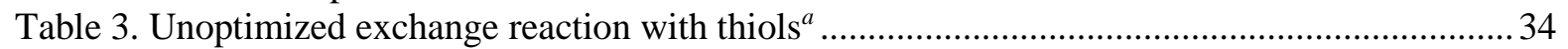

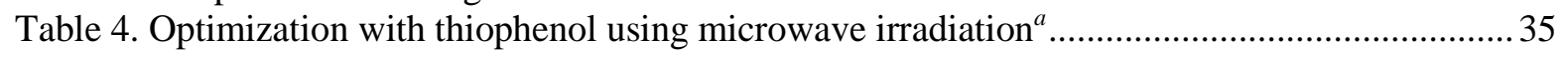

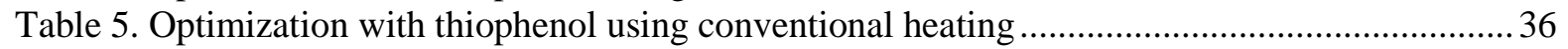

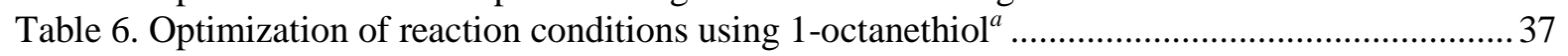

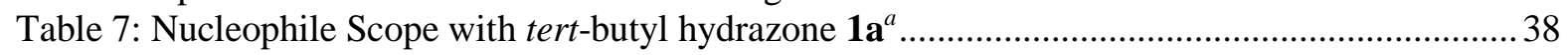

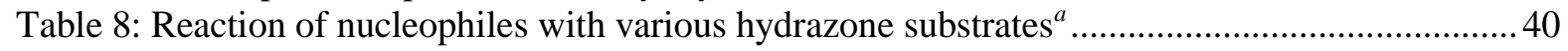

Table 9. Leaving group exchange reaction with various alcohols as nucleophiles ${ }^{a}$........................... 41

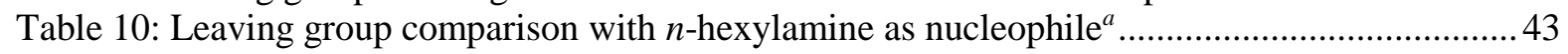

Table 11: Room temperature leaving group exchange with various equivalents of $n$-hexylamine ..... 47

Table 12. leaving group exchange reaction with the acyl substituted imino-isocyanate substrate ${ }^{a} \ldots . .54$

Table 13. Leaving group exchange reaction with methylated hydrazone substrate ...........................57 


\section{Chapter 1: INTRODUCTION}

\subsection{Isocyanates}

The isocyanate functional group has the general structure $\mathrm{R}-\mathrm{N}=\mathrm{C}=\mathrm{O}$, with an electrophilic carbon atom (Figure 1) that reacts readily with nucleophiles. Isocyanates have a broad spectrum of uses that ranges from consumer goods and industrial applications to being useful research and synthetic tools.

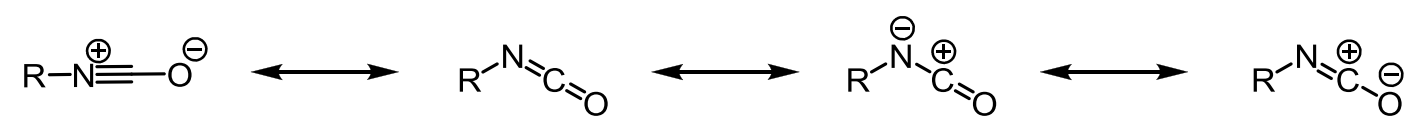

Figure 1. Resonance structures of isocyanate group

\subsubsection{Industrial Use of Isocyanates}

Isocyanates can be used to make many products such as adhesives, coatings, insulations, foams, paints, and sealants. The properties of the final products produced are dependent on the building blocks used. Many commercial products feature diisocyanates and polyisocyanates, as they allow for the formation of polymers. ${ }^{1}$ With just one reactive functional group on a molecule, it is not always possible to form polymers (long segments of repeating monomer units), but with more than one reactive group (isocyanate group for example) this is possible. Figure 2 shows a few examples of the isocyanates commonly used for industrial purposes.

${ }^{1}$ Six, C.; Richter, F. In Ullmann's Encyclopedia of Industrial Chemistry; Wiley-VCH: 2012; Vol. 20, pp 63-82. 

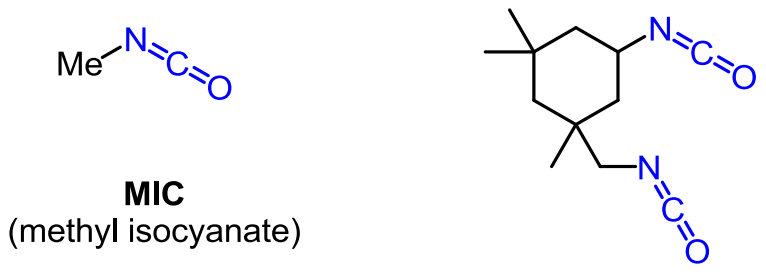

IPDI<smiles>Cc1cc(N=C=O)ccc1N=C=O</smiles>

TDI

(toluene diisocyanate)

(isophorone diisocyanate)

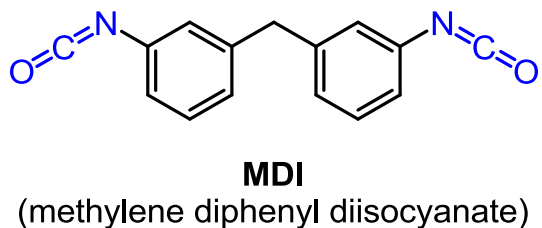

Figure 2. Common isocyanates used in industry

The isocyanate industry is worth billions of dollars and a large portion of the industry involves the production of polyurethane polymers (Scheme 1). Every year, over 400000 tons of polyurethanes are produced worldwide. ${ }^{2}$

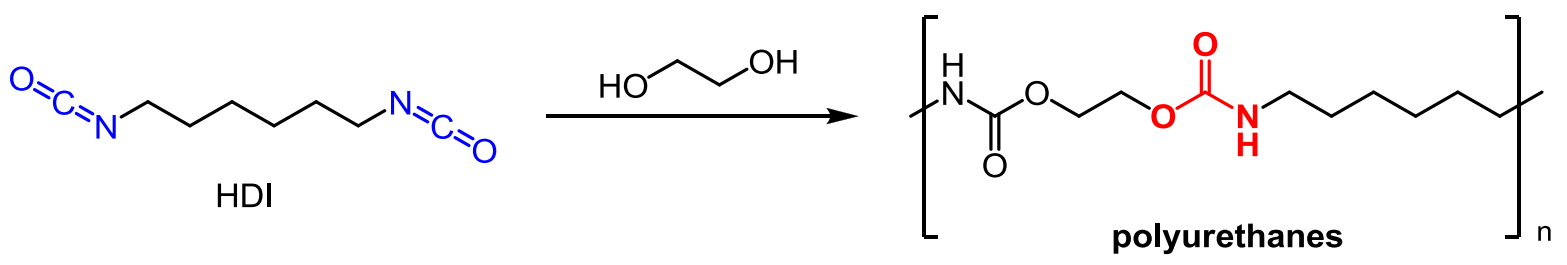

Scheme 1. Formation of a polyurethane using hexamethylene diisocyanate and ethanediol

Polyurethanes are produced from diisocyanates (such as hexamethylene diisocyanate) and diols or polyols. This leads to the formation of carbamate functional groups (shown in red in Scheme 1), also known as urethane group. This addition of alcohols to isocyanates has been known since 1849, when work was published by Wurtz. ${ }^{3}$ Further studies on the reactivity and scope of polyurethane formation was published in $1947 . .^{4}$ This urethane linkage is not the only way that crosslinking occurs in

\footnotetext{
${ }^{2}$ Meier-Westhues, U. Polyurethanes: Coatings, Adhesives and Sealants; Vincentz Network GmbH and Co: Hannover, Germany, 2007; 19-21

${ }^{3}$ Wurtz, A. Compt. Rend. 1848, 27, 242; Wurtz, A. Liebigs. Ann. Chem. 1849, 71, 326

${ }^{4}$ Bayer, O. Angew. Chem. 1947, A59, 257
} 
polyurethanes. It is possible to have urea and trimer groups (see Chapter 1.2 for discussion, Figure 10) as linkages, and even biuret groups from the further reaction of ureas under the heating conditions (Figure 3). ${ }^{5}$ Each of these groups will have an impact on the properties of the final polymer.<smiles>[R]NC(=O)O[R]</smiles>

carbamate<smiles>NC(=O)c1ccccc1</smiles>

urea<smiles>[R]n1c(=O)n([R])c(=O)n([R])c1=O</smiles>

isocyanate trimer<smiles>NC(=O)NC(N)=O</smiles>

biuret

Figure 3. Possible linkages that may form in polyurethanes

The reaction of isocyanates with primary and secondary amines allows for the formation of di- and trisubstituted ureas, respectively (Eq 1, Figure 4). These polyureas find uses in paints and varnishes, and have interesting properties since their melting points are much higher than polyurethanes. ${ }^{6}$ Another method for the formation of polyureas involves reacting isocyanates with water to generate carbamic acids (Eq 2, Figure 4). The carbamic acid undergoes decarboxylation to form an amine which then reacts with excess isocyanate present to form polyureas. ${ }^{6}$

\footnotetext{
${ }^{5}$ Ulrich, H. Kirk-Othmer Encyclopedia of Chemical Technology, Wiley-VCH: 2009, Vol. 25, pp 1-35 ${ }^{6}$ Six, C.; Richter, F. In Ullmann's Encyclopedia of Industrial Chemistry; Wiley-VCH: 2012; Vol. 29, pp 545604
} 


$$
\begin{aligned}
& \mathrm{R}^{-} \mathrm{N}^{\mathrm{C}} \mathrm{C}_{\mathrm{O}}+\mathrm{H}_{2} \mathrm{~N}^{-\mathrm{R}^{\prime} \longrightarrow} \longrightarrow \mathrm{R}_{\mathrm{H}}^{\mathrm{N}}
\end{aligned}
$$

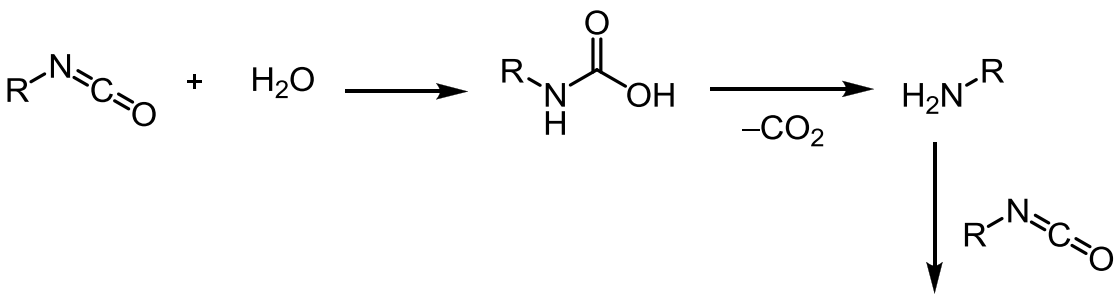

$$
\begin{aligned}
& \mathrm{H}_{\mathrm{H}}^{\mathrm{O}} \stackrel{\mathrm{H}}{\mathrm{H}}^{-\mathrm{R}}
\end{aligned}
$$

Figure 4. Formation of ureas from isocyanates

\subsubsection{Formation of Isocyanates}

There are numerous methods for the formation of isocyanates. One common approach is with the use of phosgene (diphosgene and triphosgene also) and an amine (Scheme 2). ${ }^{7}$ This method is still currently used on large scale to produce many industrial isocyanates and diisocyanates, notably for polyurethane production. ${ }^{8}$<smiles>O=C(Cl)Cl</smiles><smiles>CCOC(=O)CCc1ccc(N)cc1[N+](=O)[O-]</smiles><smiles>O=C(Cl)Nc1ccc([N+](=O)[O-])cc1</smiles>

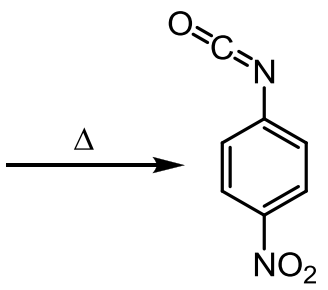

Scheme 2. Formation of $p$-nitrophenyl isocyanate from phosgene and $p$-nitroaniline

Alternatives to the use of phosgene for isocyanate formation are of interest due to the toxicity of phosgene. The Hofmann ${ }^{9}$ (Eq 3, Scheme 3) and Curtius rearrangements (Eq 4, Scheme 3) are

\footnotetext{
${ }^{7}$ Shriner, R. L.; Horne, W. H.; Cox, R. F. B. Org. Synth. 1943, 2, 453

${ }^{8}$ Phosgene and Related Carbonyl Halides. Topics in Inorganic and General Chemistry, Elsevier Ltd: 1996; Vol. 24, pp 3-932

${ }^{9}$ Hofmann, A. W. Chem. Ber. 1881, 14, 2725
} 
additional methods to form isocyanates. The ability to use amides or acyl azides as starting materials can be useful and allow the formation of isocyanates that would be difficult to access through the use of phosgene. ${ }^{10}$
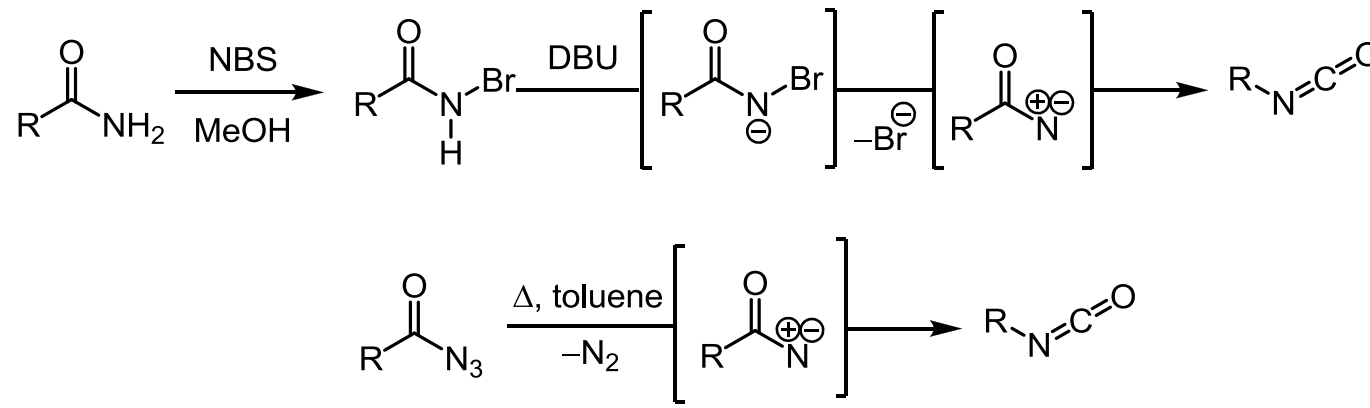

Scheme 3. Formation of isocyanate via nitrenes, using the Hofmann (Eq 3) and Curtius rearrangements (Eq 4)

In Scheme 3, a modified Hofmann rearrangement is shown with the use of NBS and DBU in methanol. ${ }^{11}$ This is an alternative to the use of bromine (original reaction conditions developed by Hofmann), which can be incompatible with certain reactants that may be used. This reactivity can also proceed under non-basic conditions with the use of lead tetraacetate. ${ }^{12}$ An additional non-phosgene approach to isocyanates formation is with the use of carbon monoxide. When combined with an appropriate catalyst and either nitro or amino compounds, the corresponding isocyanate can be generated. A variety of different catalysts work, for example ruthenium based catalysts ${ }^{13}$, rhodium carbonyl chlorides (with pyridine as activator), ${ }^{14}$ and palladium pyridine complexes. ${ }^{15}$ An example is provided in Figure 5.

\footnotetext{
${ }^{10}$ Isocyanates, Organic. Kirk-Othmer Encyclopedia of Chemical Technology, 3rd ed.; Wiley: New York, 1982; Vol. 19, pp 28-62.

${ }^{11}$ Keillor, J. W.; Huang, X. Org. Synth. 2002, 78, 234

${ }^{12}$ Baumgarten, H. E.; Stalkis, A. J. Am. Chem. Soc. 1965, 87, 1141

${ }^{13}$ Basu, A.; Bhaduri, S.; Khwaja, H. J. Organomet. Chem. 1987, 319, C28

${ }^{14}$ Manov-Yuvenskii, V. I.; Smetanin, A. V.; Nefedov, B. K. Russ. Chem. Bull. 1980, 11, 1817

15 Takebayashi, Y.; Sue, K.; Yoda, S.; Furuya, T.; Mae, K. Chem. Eng. J. 2012, 180, 250
} 


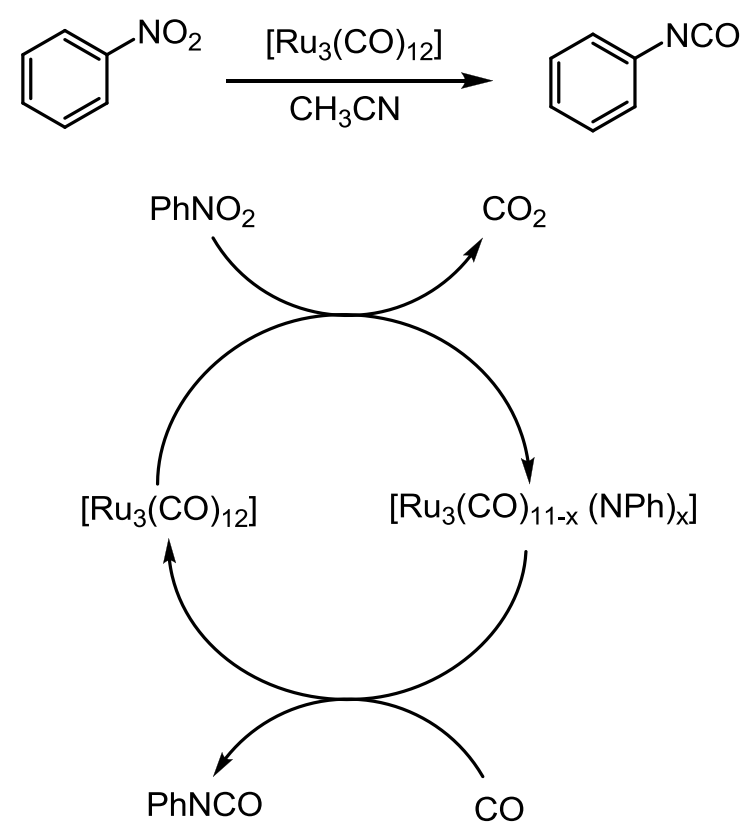

Figure 5. Mechanism for the generation of isocyanates from carbon monoxide using ruthenium catalysis

Carbonyl equivalents such as CDI can also provide useful methods for accessing isocyanates by reaction with hydroxamic acids, for example with the Lossen rearrangement (Scheme 4). ${ }^{16}$ Other acyl equivalents are compatible and work well, including sulfonyl or phosphoryl reagents. ${ }^{17}$<smiles>CCC(=O)Cl</smiles>

hydroxamic acid<smiles>CCC(=O)ONC(=O)c1ccccc1</smiles>

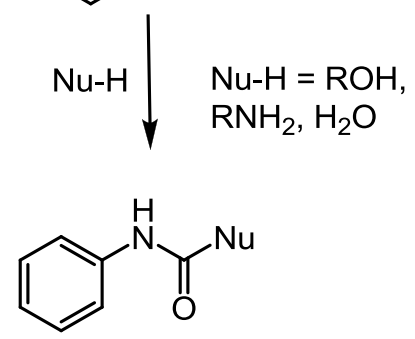

Scheme 4. Lossen rearrangement using hydroxamic acid to form isocyanates

\footnotetext{
${ }^{16}$ Dubé, P.; Nathel, N. F.; Vetelino, M.; Couturier, M.; Larrivée, A.; Pichette, S.; Jorgenson, M. L.; Hardink, M. Org. Lett. 2009, 24, 5622

${ }^{17}$ Wang, Z. Comprehensive Organic Name Reactions and Reagents; Wiley: New York, 2009, 1772-1774
} 


\subsubsection{Examples of Isocyanate Reactivity}

In 2012, Bode published a useful approach to form hindered amides through the use of isocyanates. ${ }^{18}$ By combining isocyanates with Grignard reagents, hindered amides could be easily synthesized (Scheme 5).
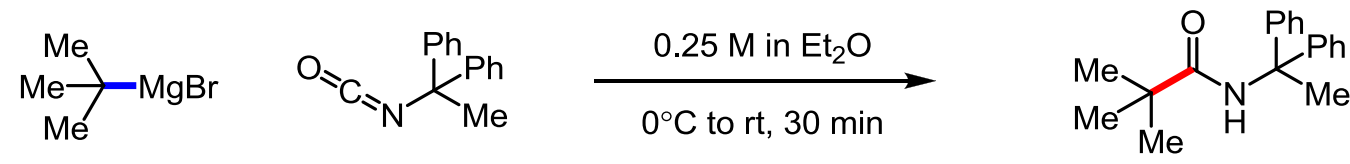

$95 \%$

\section{Scheme 5. Formation of hindered amides employing Grignard reagents and isocyanates}

Other methods used to form amides, such as coupling of amines and carboxylic acids, show limitations when it comes to using electron deficient or sterically hindered amines. This approach developed by Bode addresses this issue, and provides a different way to synthesize amides.

Rovis has developed rhodium catalyzed cycloaddition reactions to access indo- and quinolizidine alkaloid natural products (Scheme 6). Using pentenyl isocyanate and terminal alkynes it is possible to access two different products, vinylogous amides and/or bicyclic lactams. This reactivity has been shown to be regio- and enantioselective under the reaction conditions. ${ }^{19}$
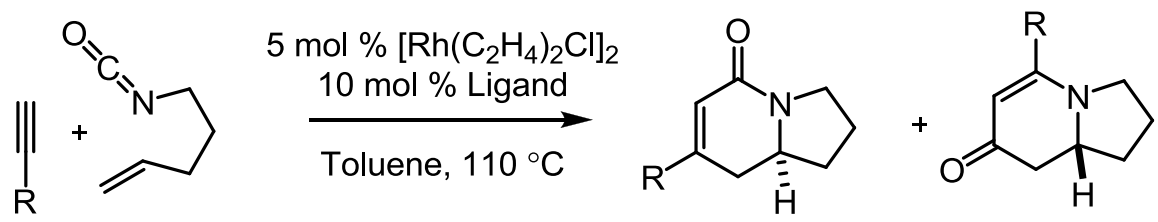

Scheme 6. Rhodium catalyzed cycloaddition developed by Rovis

The substituent present on the alkyne plays a large role in determining the regioselectivity of the reaction. When an aryl alkyne is used (Eq 5, Scheme 7), the vinylogous amide is the major product,

\footnotetext{
${ }^{18}$ Schafer, G.; Matthey, C.; Bode, J. W. Angew. Chem., Int. Ed. 2012, 51, 9173
}

${ }^{19}$ Yu, R. T.; Rovis, T. J. Am. Chem. Soc. 2006, 128, 12370 
versus with aliphatic alkynes the lactam is favoured (Eq 6, Scheme 7). This bias was used to achieve selectivities between the two possible products of greater than 20:1 in many cases. More recent work showed improved selectivities due to better catalyst and ligand, and the use of this reaction in the synthesis of an indolizidine. ${ }^{20}$

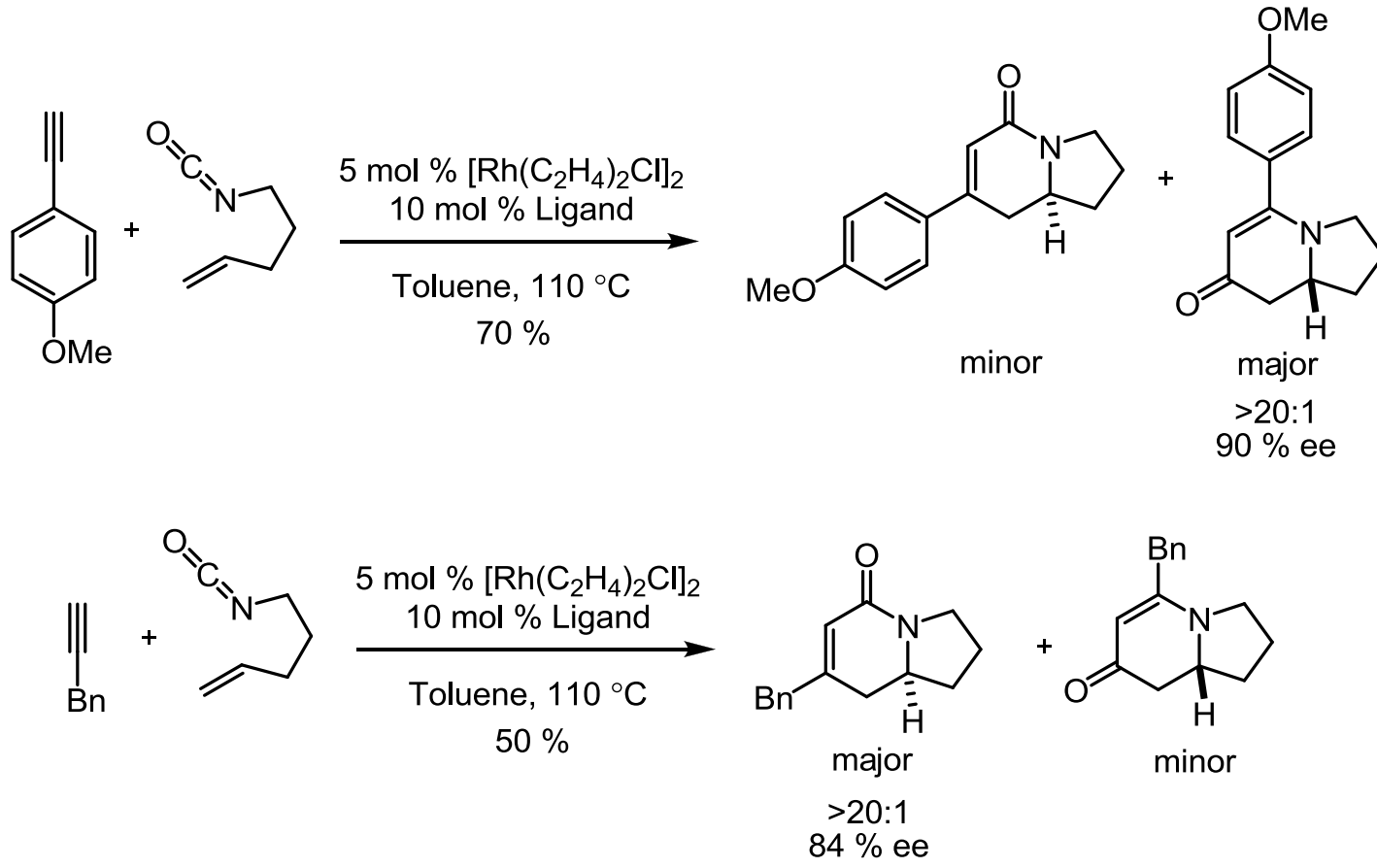

\section{Scheme 7. Formation of vinylogous amides and bicyclic lactams from cycloaddition of isocyanates and alkynes}

As an alternative to the Biginelli reaction (a multicomponent reaction using ureas, aryl aldehydes and acetoacetate), Rovis developed rhodium catalysis conditions for the formation of pyrimidines using isocyanates and $\alpha, \beta$-unsaturated imines (Scheme 8). ${ }^{21}$ These rhodium catalyzed [4+2] cycloadditions can provide desired products in high yields when the substitution at the 4-position is electron deficient. In order to achieve higher enantioselectivities, electron-rich aryl substituents are required but this leads to lower yields.

${ }^{20}$ Yu, R. T.; Lee, E. E.; Malik, G.; Rovis, T. Angew. Chem., Int. Ed. 2009, 48, 2379

${ }^{21}$ Oberg, K. M., Rovis, T. J. Am. Chem. Soc. 2011, 133, 4785 

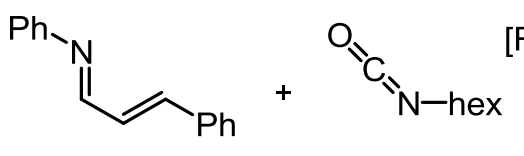

$\left.\mathrm{Rh}\left(\mathrm{C}_{2} \mathrm{H}_{4}\right)_{2} \mathrm{Cl}\right]_{2}(5 \mathrm{~mol} \%)$

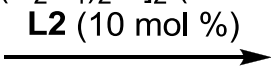

$\mathrm{PhMe}, 110^{\circ} \mathrm{C}$<smiles>O=C(c1ccccc1)N1C(=O)N(c2ccccc2)C=CC1c1ccccc1</smiles><smiles>CC1(C)OC2[C@H](O1)C(c1ccccc1)(c1ccccc1)OP(N1CCCC1)OC2(c1ccccc1)c1ccccc1</smiles>

Scheme 8. Pyrimidinone formation by rhodium catalyzed cyclization of isocyanate and $\alpha, \beta$-unsaturated imines

Similar isocyanate reactivity was published in 1983 by Hoberg and Summermann. ${ }^{22}$ The formation of a nickel metallocycle was reported starting from an isocyanate and an imine. The mechanism proposed by Rovis for the formation of the pyrimidinone is similar, with a 5 then 7 membered rhodium metallocycle proposed..$^{21}$

In 2012, Buchwald published work demonstrating the formation of isocyanates in situ by coupling aryl halides (and triflates) with sodium cyanate using palladium (Scheme 9). ${ }^{23}$

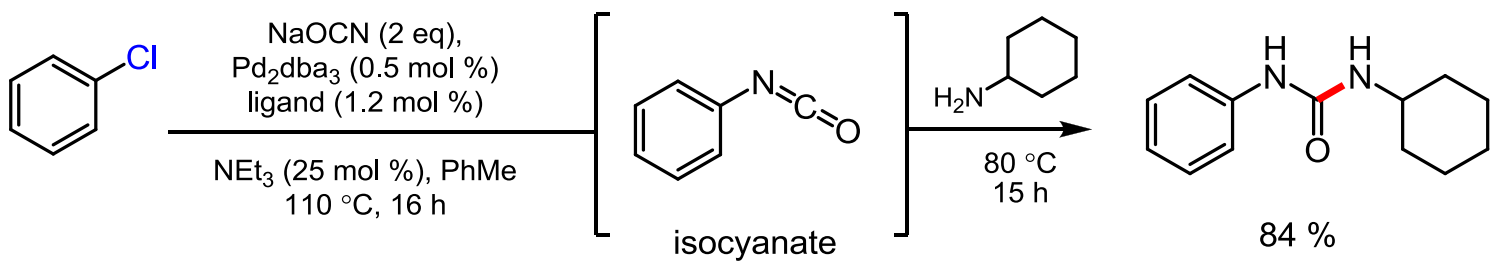

Scheme 9. Palladium coupling with phenyl chloride and sodium cyanate; formation of isocyanates and ureas

The isocyanate generated in situ was then allowed to react with a variety of amines (mainly aryl amines) to form the corresponding urea. Substrates that proved difficult (hindered amines for example)

${ }^{22}$ Hoberg, H.; Summermann, K. J. Organomet. Chem. 1983, 253, 383

${ }^{23}$ Vinogradova, E. V.; Fors, B. P.; Buchwald, S. L. J. Am. Chem. Soc. 2012, 134, 11132 
showed much better yields when phenol was used as an additive in the reaction. Phenol allows for the formation of the corresponding carbamate in situ via the isocyanate intermediate (Scheme 10).

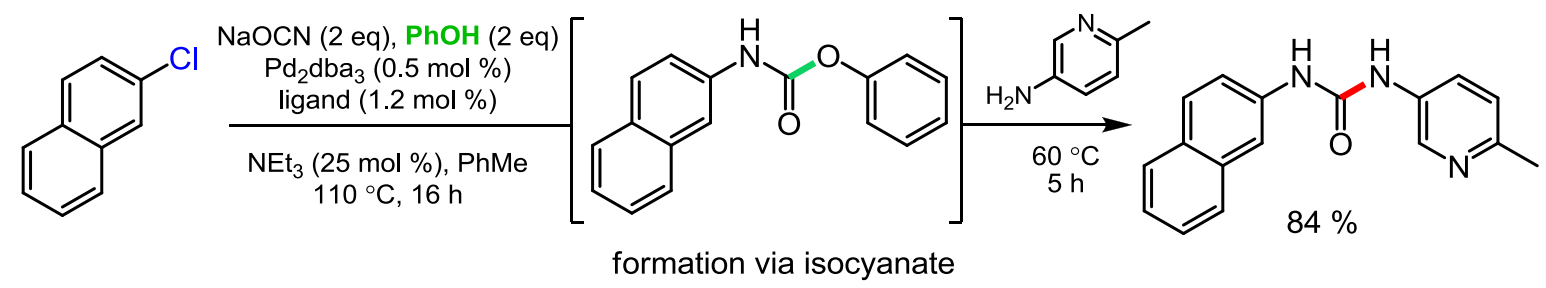

\section{Scheme 10. Use of phenol as additive in formation of ureas coupling aryl chloride and sodium cyanate}

The added phenol acts as a leaving group on the carbamate, essentially making the carbamate a blocked isocyanate (discussed in Chapter 1.2). The phenol leaving group allows the carbamate to then regenerate the isocyanate and react with the desired nucleophile. Overall this approach allows for the formation of a variety of unsymmetrical aryl ureas from relatively simple aryl chlorides and amines.

\subsection{Blocked Isocyanates}

The toxicity of isocyanates can present a serious health risk if they not handled correctly. Many isocyanates are known to cause sensitivity issues to the skin and respiratory tract. Low concentration exposure to isocyanates has been linked to the development of asthma. ${ }^{24}$ Exposure to isocyanates over time leads to workers becoming sensitized and once sensitized, even exposure to very small amounts of isocyanates (as low as $1 \mathrm{ppb}$ ) can result in an allergic reaction. ${ }^{25}$ In Sweden, diisocyanate 2,4-TDI has been labeled a carcinogen, and a workplace concentration of $2.5 \mathrm{ppm}$ or more is considered “immediately dangerous to life and health". ${ }^{26}$ Development of blocked isocyanates has been one way

\footnotetext{
${ }^{24}$ Meredith, S.K.; Bugler, J.; Clarke, R. L. Isocyanate exposure and occupational asthma: a case reference study.

Occupational Environment Medicine 2000; 57:830-836

${ }^{25}$ Roberge, B.; Gravel, R.; Drolet, D. 4,4'-Diphenylmethane diisocyanate (MDI): safety practices and concentration during polyurethane foam spraying. IRSST: Quebec, 2009.

${ }^{26}$ AFS Occupational exposure limit values. Arbetarskyddsstyrelsens Foorfattningssamling . AFS 200:3, Liber: Stockholm,Sweden (in Swedish), 2000
} 
to reduce exposure of workers to isocyanates. Since the introduction of blocked isocyanates, certain applications have embraced their use, for example isocyanate based coatings. ${ }^{27}$

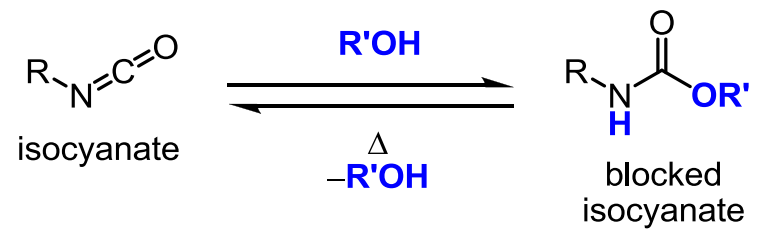

Figure 6. Formation of a blocked isocyanate using and an alcohol as a blocking agent to form a carbamate ester

Blocked isocyanates contain a leaving group that allows for the formation of an isocyanate under specific conditions but otherwise keeps the reactive isocyanate in a much less reactive form. Figure 6 shows the formation of a blocked isocyanate when an alcohol is reacted with the isocyanate.
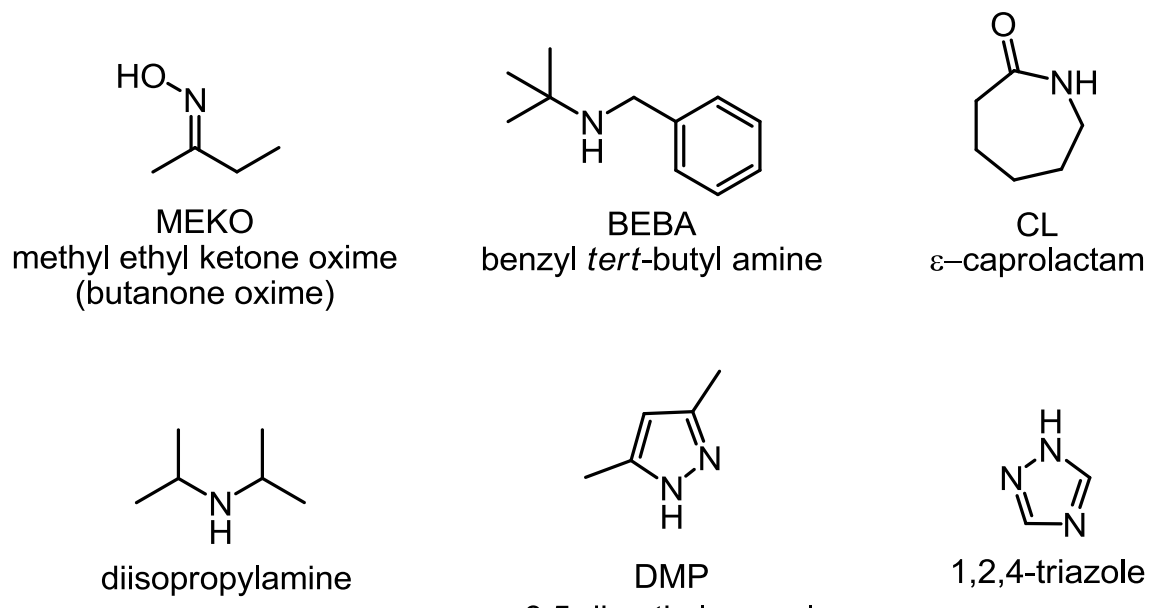

dilisopropylamine

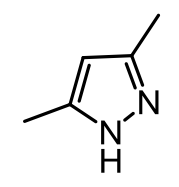

DMP

\section{3,5-dimethylpyrazole}<smiles>c1nc[nH]n1</smiles>

1,2,4-triazole

Figure 7: commonly used blocking agents for isocyanates

There are different methods for producing blocked isocyanates, mainly involving the use of a nucleophile containing an active proton (acidic proton). Compounds with active protons includes alcohols, thiols, and amines. Ideally, a weak nucleophile will need to react with the isocyanate, since a strong nucleophile would make regeneration of the isocyanate difficult. Commonly used blocking agents are shown in Figure 7. MEKO (methyl ethyl ketone oxime) is a blocking agent used in industry

\footnotetext{
${ }^{27}$ Wicks, D. A.; Wicks, Z. W. Jr. Prog. Org. Coat. 1999, 36, 148
} 
and is considered a low temperature deblocking agent (still requires heating, but less in comparison to other blocking agents) (Figure 8). ${ }^{28}$

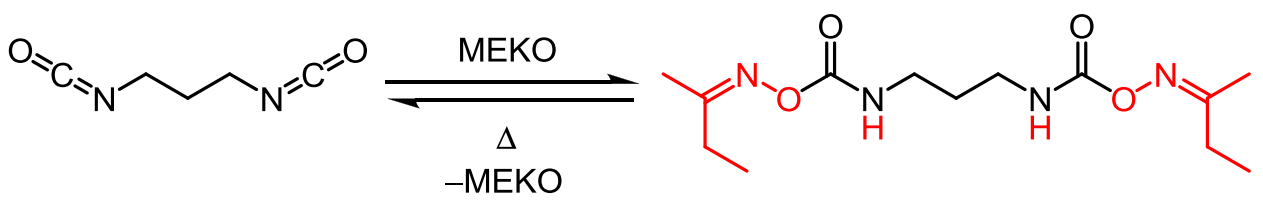

Figure 8: Formation of a blocked diisocyanate using MEKO as a blocking agent and upon heating the diisocyanate can be regenerated

Isocyanates blocked with MEKO will not be as stable as substrates containing alcohol based blocking agents (which require higher temperature to be removed). For example, MEKO blocked MDI emulsions are only known to be stable in storage at room temperature for 3 months. ${ }^{29}$ Compare this to 1,2.4-tiazole blocked isocyanates, which are generally stable up to temperatures of $130-140{ }^{\circ} \mathrm{C} .1,2,4-$ triazole is a commonly used blocking agent and is often used in combination with diisopropylamine since both have a relatively low cross linking temperature of around $139{ }^{\circ} \mathrm{C}$ (based on use with 1,6 hexane derived polyisocyanates). ${ }^{30}$

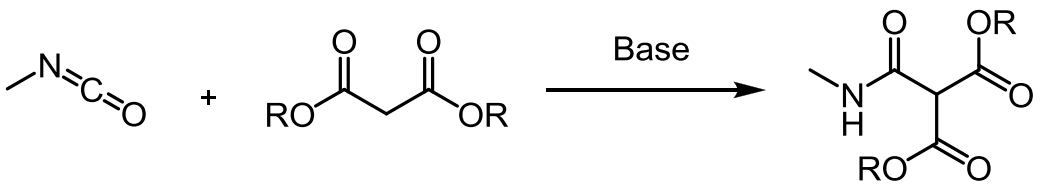

Scheme 11: Methyl isocyanate blocked with malonic ester

Malonic esters (Scheme 11) are another option for making blocked isocyanates. ${ }^{27}$ The use of $\beta$ dicarbonyl compounds as blocking agents allows for the regeneration of isocyanates at relatively low temperatures. $^{31}$ For example, isocyanates can be detected upon heating TDI blocked with diethyl malonate at temperatures as low as $79{ }^{\circ} \mathrm{C} .{ }^{32}$ Isocyanates blocked with malonic esters do not regenerate the isocyanate in the same way other blocking agents do and many different products may result.

\footnotetext{
${ }^{28}$ Wicks, D. A.; Wicks, Z. W. Jr Prog. Org. Coat. 2001, 41, 1

${ }^{29}$ K. Sato, K. Ishihara, M. Matsumura, M. Komori, Ger. Offen., DE, 1988, 3,807,555

${ }^{30}$ Karl Fink, J. High Performance Polymers; William Andrew Inc: 2008; pp 301-327

${ }^{31}$ Wicks, Z. W. Jr. Prog. Org. Coat. 1975, 3, 73

${ }^{32}$ Griffin, G. R.; Willwerth, L. J. Ind. Eng. Chem. Prod. Res. Develop., 1962, 1, 265
} 
<smiles>CCOC(=O)C(C(=O)NNC(=O)C1CCCCC1)C(=O)OCC</smiles>

I<smiles>CCOC(=O)C(C(=O)OCC)C(=O)OCC</smiles>

II<smiles>CCOC(=O)C(C(=O)NC1CCCCC1)C(=O)NC1CCCCC1</smiles>

III<smiles>O=C(NC1CCCCC1)C(C(=O)NC1CCCCC1)C(=O)NC1CCCCC1</smiles>

IV<smiles>O=C=N[GeH3]</smiles>

v<smiles>O=C(NC1CCCCC1)NC1CCCCC1</smiles>

VI

Figure 9: The pyrolysis of diethylmalonate blocked cyclohexylisocyanate

Typically the isocyanate is not regenerated in large amounts and instead the ester functional group reacts with the nucleophile to create the cross linkages. ${ }^{27}$ Figure 9 presents the products formed during the pyrolysis of an isocyanate blocked with diethylmalonate. ${ }^{33}$ The major products observed were starting material (I), ethanol, and compounds II and III. Small amounts of compounds IV, V, and VI were also observed. This demonstrates that in fact only small amounts of isocyanate were generated from the blocked isocyanate, and instead the major products were variations of the malonate and blocked isocyanate. One disadvantage to the use of malonic ester as a blocking agent is that it has been shown to yellow during the stoving process when used for coating applications. ${ }^{34}$ As well, it tends to crystallize during handling, which can make it difficult to manipulate.

\footnotetext{
${ }^{33}$ Kostyk, B. W.; Wicks, Z. W. Jr. J. Polym. Sci. A. Polym. Chem. 1979, 17, 2423

${ }^{34}$ Potter, T. A.; Seneker, S. D. Coating compositions based on blocked polyisocyanates and sterically hindered aromatic polyamines. US Patent, 6583216, June 24, 2003
} 
Interestingly benzyl tert-butyl amine (BEBA) and 3,5-dimethylpyrazole (DMP) are two blocking agents that pass the over-baking test (to look for yellowing) which makes them good choices as blocking agents for use in coatings for automotive purposes since they can withstand high temperatures. ${ }^{35}$ The blocking agent chosen for a particular compound can be very important and in many cases affect the properties of the final product. It is possible to have the blocking agent removed during the curing process (by evaporation) to avoid influencing the properties of the final product, although in many cases a non-volatile blocking agent is preferred, for example with powder coating. ${ }^{36}$ Powder coatings are made up of solid polyols and solid blocked polyisocyanates (hence the name powder coating). Common blocking agents chosen for powder coating purposes includes $\varepsilon$ caprolactam, ${ }^{37}$ and $1,2,4$-triazole..$^{30}$

It is possible to produce self-blocked isocyanates by allowing the isocyanate to dimerize and polymerize with itself. The self-blocked isocyanate will regenerate the isocyanate when heated, ${ }^{38}$ with no unwanted blocking agents present in the reaction mixture. Examples of the different compounds that can result from reaction of isocyanates with themselves are shown in Figure 10. ${ }^{39}$

\footnotetext{
${ }^{35}$ Meier-Westhues, U. Polyurethanes: Coatings, Adhesives and Sealants; Vincentz Network GmbH \& Co; 2007; pp 25-52

${ }^{36}$ Wicks, Z. W. Jr.; Jones, F. N.; Pappas, S. P.; Wicks, D. A. Organic Coatings: Science and Technology; Wiley-VCH: 2007, pp 231-245

${ }^{37}$ Six, C.; Richter, F. In Ullmann's Encyclopedia of Industrial Chemistry; Wiley-VCH: 2012; Vol. 29, pp 545604

${ }^{38}$ Lockley, W. J. S.; Lwowski, W. Tetrahedron Lett. 1974, 48, 4263

${ }^{39}$ Caraculacu, A.A.; Coseri, S. Prog. Polym. Sci. 2001, 26, 799
} 


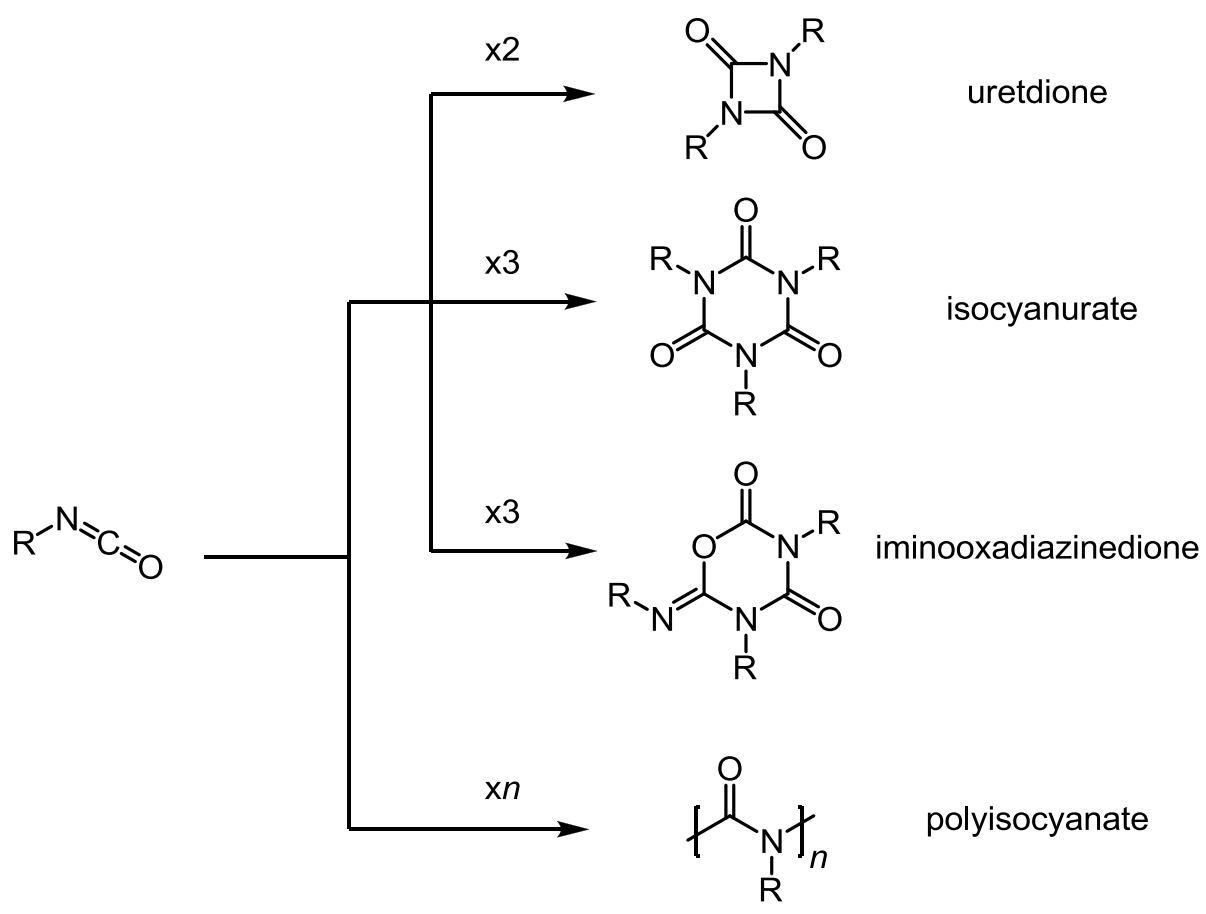

Figure 10. Dimer, trimer, and polymer structures of isocyanates

Polymerization of isocyanates is also possible and leads to the formation of polyisocyanates. The way in which an isocyanate will react with itself depends on its structure. ${ }^{5}$ Aliphatic side chains will favour formation of trimers (to yield isocyanurates) over dimers. Aromatic structures such as methylene bisphenyl diisocyanate (MDI) will prefer to form dimers since when crystalline, since the packing of the molecules on top of one another places the isocyanate groups in close proximity and allows for facile dimerization.

\subsection{N-Substituted Isocyanates: Amino- and Imino-isocyanates}

Lwowski has published work outlining how nitrogen substituted isocyanates (specifically aminoisocyanates) react with themselves and other isocyanates. ${ }^{38}$ The publication describes how cyclic aminimides (compound A, Figure 11) can generate isocyanates and amino-isocyanates upon heating. ${ }^{40}$

\footnotetext{
${ }^{40}$ Lockley, W. J. S.; Ramakrishnan, V. T.; Lwowski, W. Tetrahedron Lett. 1974, 30, 2621
} 
In Figure 11 the aminimide is heated to produce tert-butyl isocyanate and $N, N$-dimethyl aminoisocyanate. Under the reaction conditions, tert-butyl amine evaporates and the remaining aminoisocyanate dimerizes to form a new cyclic aminimide.

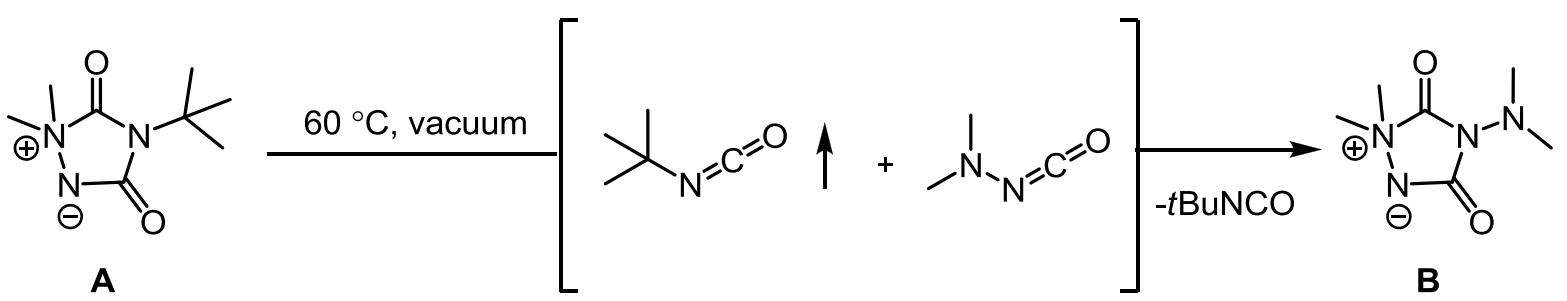

Figure 11: Cleavage of cyclic aminimide to generate isocyanate and amino-isocyanate intermediates

When the aminimide $\mathbf{A}$ is heated in the presence of phenylacetylene, the amino-isocyanate generated reacts with styrene to give the cyclic aminimide $\mathbf{C}$ shown in Figure $12 .{ }^{38}$ Both tert-butyl isocyanate and $\mathrm{N}, \mathrm{N}$-dimethylamino-isocyanate are produced in the reaction, however the tert-butyl isocyanate is removed under the reaction conditions allowing for only the amino-isocyanate to react with phenylacetylene.

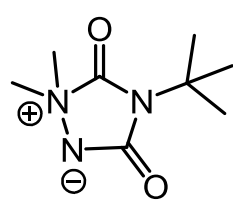

A
$\Delta$
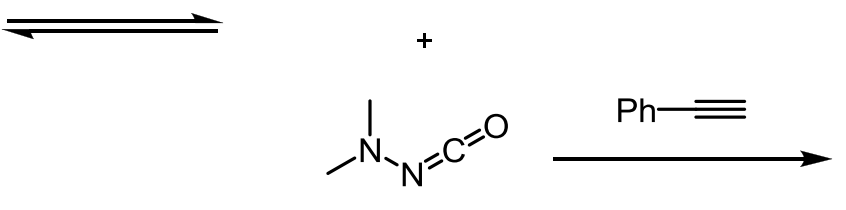

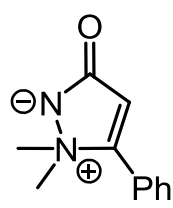

C

Figure 12. Reaction of amino-isocyanate generated from cyclic aminimide with phenylacetylene

Formation of amino-isocyanates is possible from disubstituted hydrazine and CDI (Scheme 12). For example, dimethyl hydrazine will react with CDI and displace one of the imidazole groups. The isocyanate can then be formed after the departure of the second imidazole group. When placed in 
protic solvents, the amino-isocyanate can be trapped as the corresponding carbamate. Aprotic solvents, on the other hand will help favour the formation of amino-isocyanate dimers. ${ }^{41}$

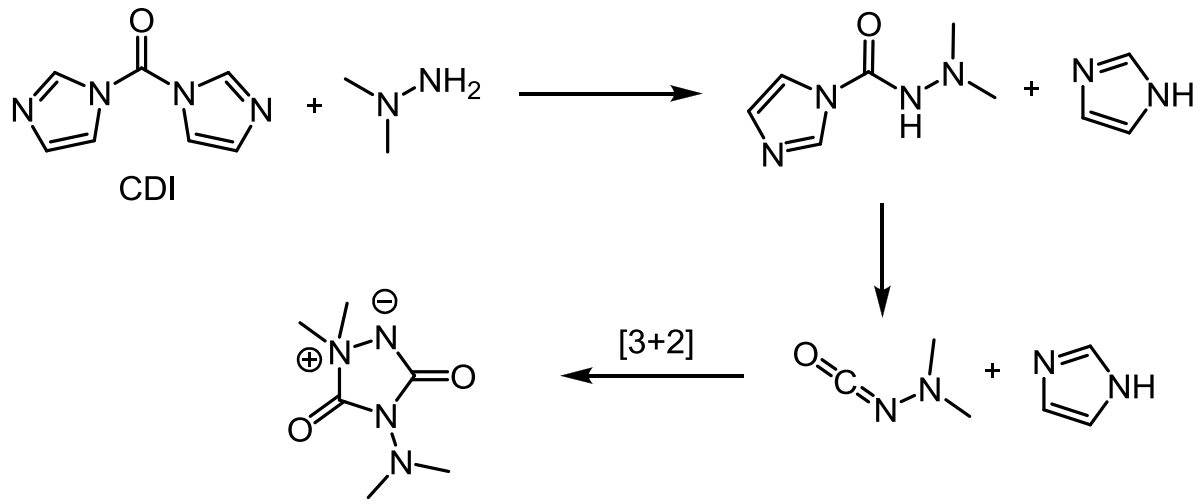

\section{Scheme 12: Formation of amino-isocyanate using CDI and $N, N$-dimethyl hydrazine and resulting [3+2] cycloaddition}

The Curtius rearrangement can be used to generate amino-isocyanates in addition to isocyanates. The starting compound is the carbamoyl azide which upon heating rearranges to give the amino-isocyanate. The mechanism is thought to be concerted and not proceed through a nitrene intermediate like the mechanism for the formation of isocyanates from azides. ${ }^{42}$ For the example shown in Scheme 13, the intermediate is able to cyclize and produce an indazolone. ${ }^{41}$

\footnotetext{
${ }^{41}$ Reichen, W. Chem. Rev. 1978, 78, 569

42 a) Koga, N.; Koga, G.; Anselme, J.-P. Tetrahedron 1972, 28, 4515; b) Reichen, W. Helv. Chim. Acta 1976, 59,2601
} 


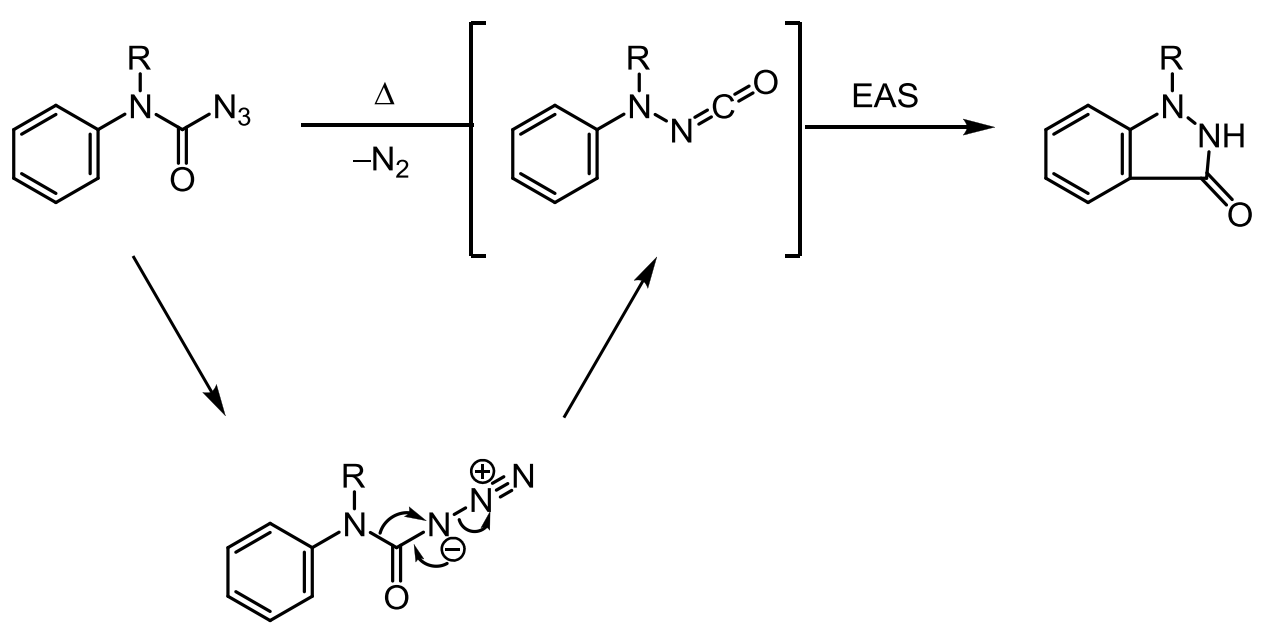

Scheme 13. Formation of amino-isocyanate via Curtius rearrangement

In a publication by Horner and Wadsworth in 1967, it was shown how $N, N$-dimethylamino isocyanate can be generated starting from the corresponding ethyl carbamate. ${ }^{43}$ The amino-isocyanate can be generated in situ with heating and the use of phosphoric acid (Scheme 14). The intermediate dimerizes to form a dipolar cyclic triazole and a subsequent 1,2-methyl migration leads to the neutral dimer product in $49 \%$ yield.

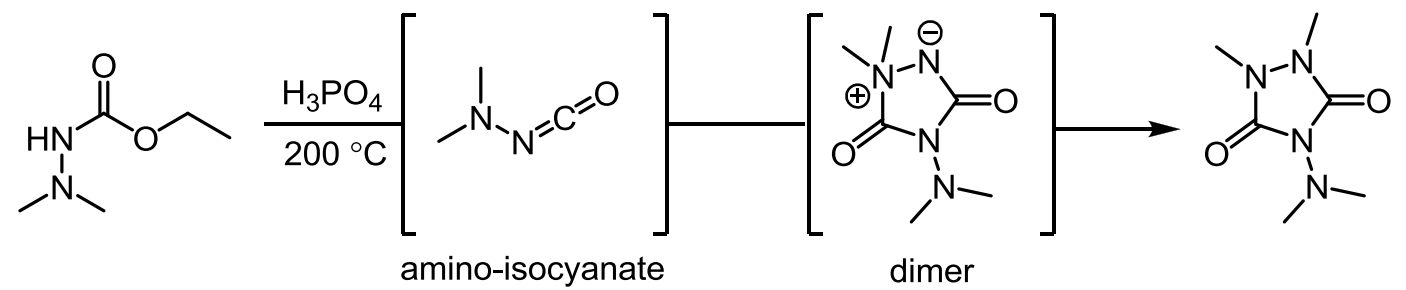

Scheme 14. Formation of amino-isocyanate dimer from $N, N$-dimethyl ethylcarbazate using phosphoric acid

Work published in 1989 by Tele and Maier outlines various ways to generate amino-isocyanates (Figure 13). ${ }^{44}$ First, it is possible to generate the amino-isocyanate through pyrolysis of carbamoyl azides (mechanistically similar to the previously mentioned Curtius rearrangement). Next, methyl

\footnotetext{
${ }^{43}$ Wadsworth, W. S.; Emmons, W. D. J. Org. Chem. 1967, 32, 1279

${ }^{44}$ Maier, G.; Teles, H. Chem. Ber. 1989, 122, 745; for review on amino-isocyanate see Wentrup, C.; Finnerty, J. J.; Koch, R. Curr. Org. Chem 2011, 15, 1745.
} 
carbazate can be used in the generation of the amino isocyanate. The pyrolysis of methyl carbazate at $500{ }^{\circ} \mathrm{C}$ leads to the loss of methanol and the generation of amino-isocyanate with only small amounts of isocyanic acid as by-product. Pyrolysis of 3,4-diaminofurazan will lead to formation of aminoisocyanates as well, but produces large amounts of unwanted by-products in the process. In all three cases, the amino-isocyanate was isolated in an argon matrix at $10 \mathrm{~K}$, which allowed for characterization by FT-IR. ${ }^{44}$

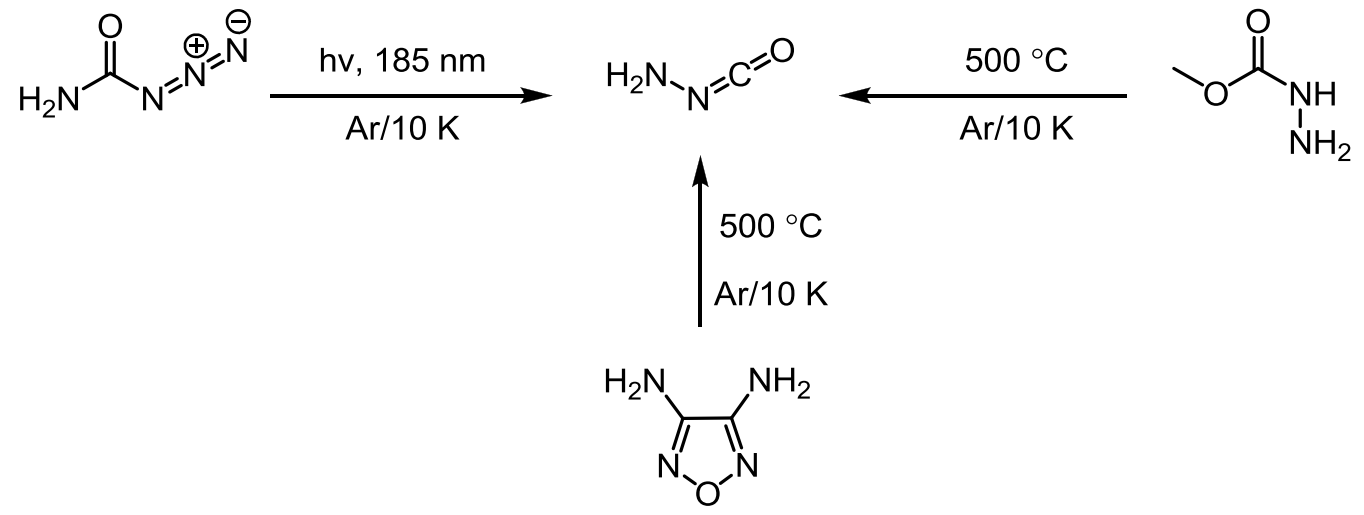

Figure 13: Generation of amino-isocyanate using photolysis and pyrolysis

Interestingly, the amino-isocyanate generated by Tele and Maier was found to be stable when exposed to light at a wavelength of $182 \mathrm{~nm}$, or greater than $366 \mathrm{~nm}$. However, when light at $254 \mathrm{~nm}$ was used, the amino-isocyanate was unstable and this lead to the formation of an amino nitrene and carbon monoxide. Previous work by Dervan on the photolysis of carbamoyl azide also supports the formation of these amino nitrenes. ${ }^{45}$ Another decomposition pathway of the amino-isocyanate was observed with $N, N$-dimethyl amino-isocyanate.

When flash vacuum thermolysis is performed on dimethyl carbamoyl azide, the loss of $\mathrm{N}_{2}$ generated the amino-isocyanate shown in Figure 14. Through a pericyclic reaction involving one of the protons of the methyl group, the amino-isocyanate converted to $N$-methylenemethylamine and cyanic acid. ${ }^{46}$

\footnotetext{
${ }^{45}$ Sylwester, A. P.; Dervan, P. B. J. Am. Chem. Soc. 1984, 106, 4648
}

${ }^{46}$ Wentrup, C.; Finnerty, J. J.; Koch, R. J. Org. Chem. 2011, 76, 6024 


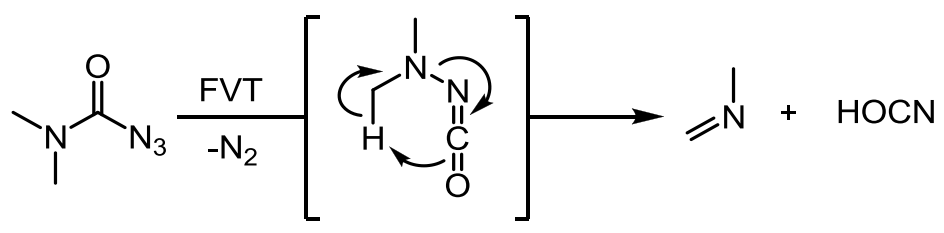

Figure 14. By-product formation of the flash vacuum thermolysis of carbamoyl azide

An imino-isocyanate differs from an amino-isocyanate by the hybridization of the distal nitrogen, $\mathrm{sp}^{3}$ in amino-isocyanates and $\mathrm{sp}^{2}$ in imino-isocyanates. There are fewer reports of imino-isocyanates in the literature than reports on amino-isocyanates. One publication studying imino-isocyanates is from 1976 by Warkentin. ${ }^{47}$ It describes the thermolysis of 2-hydrazono- $\Delta^{3}-1,3,4$-oxadiazolines and one of the products observed was an imino-isocyanate (Figure 15).
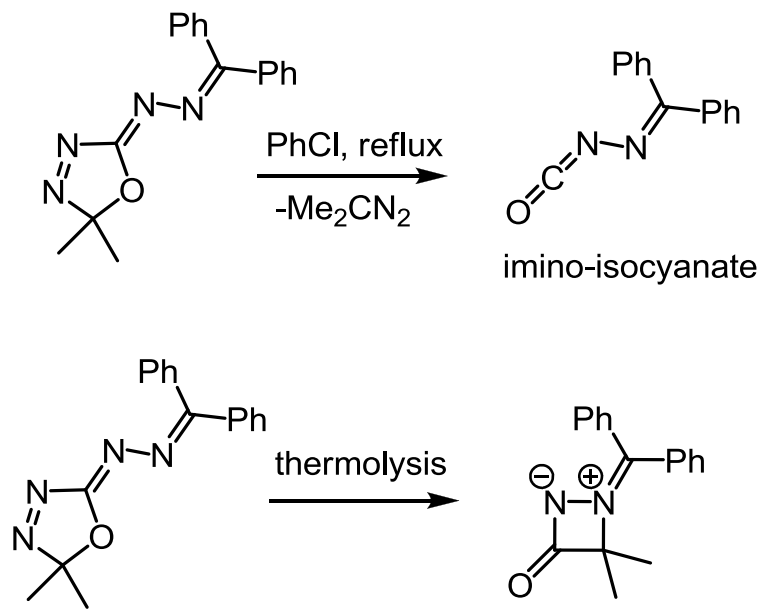

$35 \%$

Figure 15. Generation of iminio-isocyanate through the thermolysis of an oxadiazoline

Earlier reports of the thermolysis reaction (with no added trapping agents) found that the reaction gave a diazetedinone as the major product (Eq 8, Figure 15). ${ }^{48}$ The proposed mechanism to reach this product and one of the suggested pathways included an imino-isocyanate intermediate.

\footnotetext{
${ }^{47}$ Ramakrishnan, K.; Fulton, J.B.; Warkentin, J. Tetrahedron 1976, 32, 2685
}

${ }^{48}$ Ip, P.C.; Ramakrishnan, K.; Warkentin, J. Can. J. Chem. 1968, 33, 2089 
A later publication by Warkentin describes this thermolysis reaction with the addition of trapping agents, in hopes of determining if one of the intermediates is in fact an imino-isocyanate. ${ }^{47}$ When phenylisocyanate was used as an additive, a product other than the previously observed diazetinone was formed. This new cyclic product was found to be generated from two consecutive 1,3-dipolar cycloadditions. The first is between the phenylisocyanate additive and the imino-isocyanate intermediate, the second cycloaddition occurs between the new dipolar product and a second equivalent of phenylisocyanate (Scheme 15). The formation of this 1,3-dipolar cycloaddition product provided evidence to suggest that the imino-isocyanate is in fact an intermediate in the reaction.

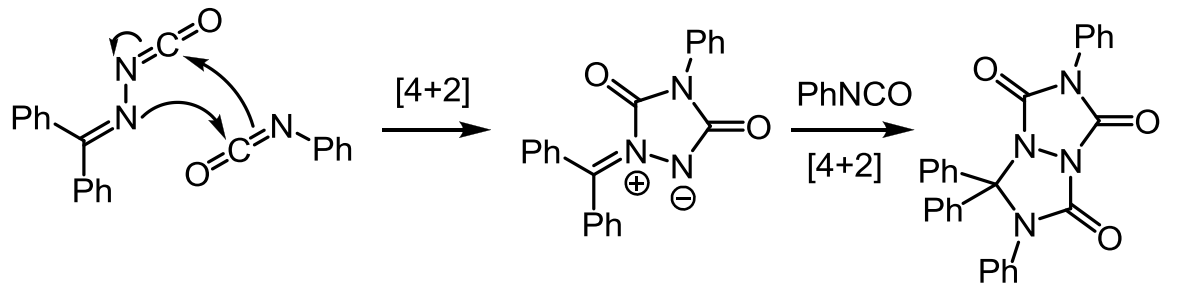

Scheme 15. Cycloaddition of diphenyl imino-isocyanate and phenyl isocyanate

\subsection{Leaving Group Exchange Reactivity - Imino-isocyanates}

In addition to cycloadditions, amino- and imino-isocyanates can also react with a variety of nucleophiles in the same way isocyanates do. The use of blocked imino-isocyanates in this type of reaction had not been thoroughly studied in the literature. The imino-isocyanate can be generated in situ, and trapped with a nucleophile to yield a new blocked isocyanate (Scheme 16).

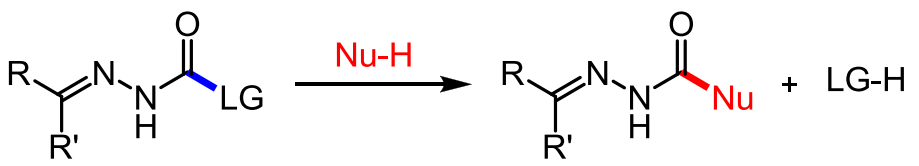

Scheme 16: General reaction scheme for the leaving group (LG) substitution 
One of the earliest accounts of this type of reactivity was in 1905 when Borsche published the exchange of an -OEt for an -NHPh on an acyl hydrazone (Scheme 17). ${ }^{49}$ The paper also included the solvolysis of the acyl hydrazone with $\mathrm{NH}_{3}$ as a leaving group and aniline as a nucleophile.

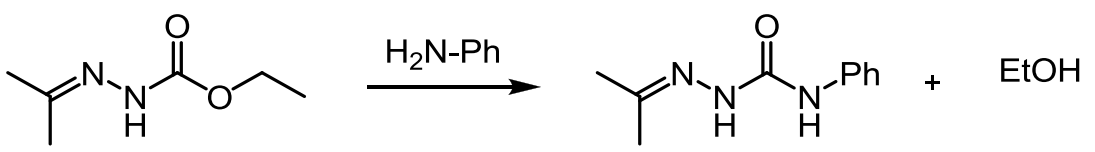

\section{Scheme 17. Leaving group exchange with aniline as nucleophile and ethanol as leaving group}

Work by Lubell ${ }^{50}$ provides additional examples of this type of reactivity with acyl hydrazones, specifically with the use of $p$-nitrophenol as a leaving group (Scheme 18). This reactivity has been used to form aza-peptides, with the acyl hydrazones being used as peptide building blocks. The approach used by Lubell starts from the $p$-nitrophenyl chloroformate. A hydrazone is reacted with the chloroformate at $0{ }^{\circ} \mathrm{C}$ to form the desired acyl hydrazone, then the amine of choice can be incorporated at room temperature using diisopropylethylamine (DIPEA) as catalyst. ${ }^{51}$ This has been shown to work for a variety of amines such as amino acids, amino esters and peptide sequences. ${ }^{52}$

${ }^{49}$ Borsch, W. Ber. Dtsch. Chem. Ges. 1905, 38, 831

${ }^{50}$ a) Proulx, C.; Lubell, W. D. J. Org. Chem, 2010, 75, 5385; b) Proulx, C.; Lubell, W. D. Org Lett. 2010, 12 , 2916; c) Sabatino, D.; Proulx, C.; Pohankova, P.; Ong, H.; Lubell, W. D. J. Am. Chem. Soc. 2011, 133, 12493; d) Bourguet, C. B.; Proulx, C.; Klocek, S.; Sabatino, D.; Lubell, W.D. J. Pept. Sci. 2010 16, 284

${ }^{51}$ Sabatino, D.; Proulx, C.; Klocek, S.; Bourguet, C. B.; Boeglin, D.; Ong, H.; Lubell, W. D. Org. Lett. 2009, 11,3650

${ }^{52}$ Bourguet, C. B.; Proulx, C.; Klocek, S.; Sabatino, D.; Lubell, W.D. J. Pept. Sci. 2010 16, 284 

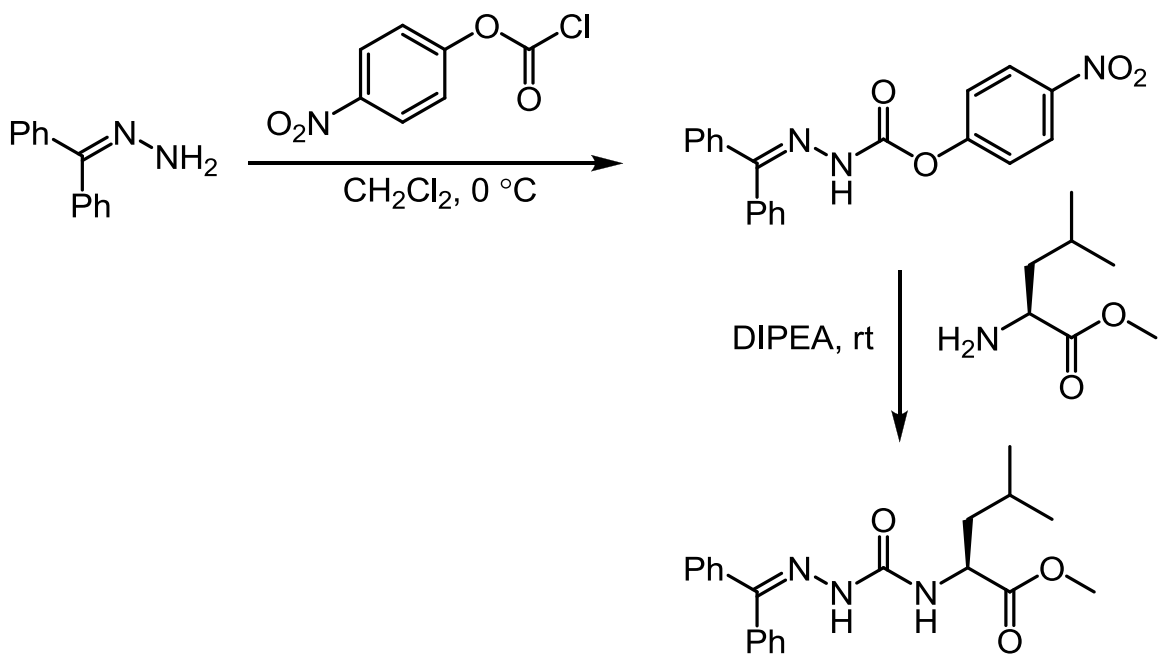

$62 \%$

aza-peptide

\section{Scheme 18. Example of a substitution reaction using $p$-nitrophenol as leaving group and amino ester as nucleophile to form an aza-peptide}

The author explains that this reaction is believed to proceed through an addition-elimination type pathway in which the $p$-nitrophenyl group is activating the carbonyl. ${ }^{53}$ However, it may be possible that this reaction is proceeding through an imino-isocyanate intermediate due to the mild reaction conditions, although this topic is not discussed by the author.

In a 2009 publication on the ortho-carbonylation of aniline derivatives, Lloyd-Jones and BookerMilburn presented results illustrating that an aryl urea could undergo hydrolysis to give the corresponding aniline under mild conditions. ${ }^{54}$ Interestingly, this was only possible with one of the three ureas investigated. The $N, N$-diisopropyl urea provided the corresponding aniline when exposed to water under reflux conditions. The $N, N$-diethyl and $N, N$-dimethyl substrates showed no reactivity under these same conditions (Figure 16).

\footnotetext{
${ }^{53}$ Garcia-Ramos, Y.; Proulx, C.; Lubell, W. D. Can. J. Chem. 2012, 90, 985

${ }^{54}$ Hutchby, M., Houlden, C. E., Gair Ford, J., Tyler, S. N. G., Gagné, M. R., Lloyd-Jones, G. C., BookerMilburn, K. I. Angew. Chem., Int. Ed. 2009,48,1830
} 


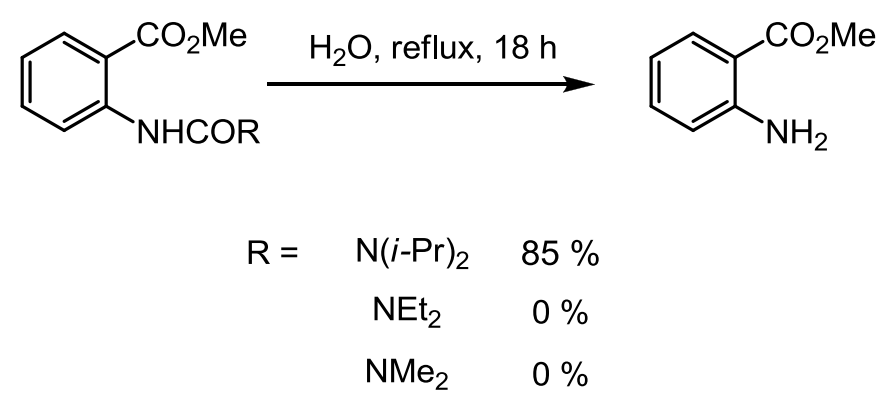

Figure 16: Impact of nitrogen substitution on hydrolysis of aryl ureas

Later in 2009, Lloyd-Jones and Booker-Milburn published work providing further studies into why the diisopropyl substrate displays this interesting reactivity. ${ }^{55}$ The solvolysis of various aniline-based ureas in methanol were compared and some were found to undergo methanolysis at temperatures as low as $20^{\circ} \mathrm{C}$ (Figure 17).

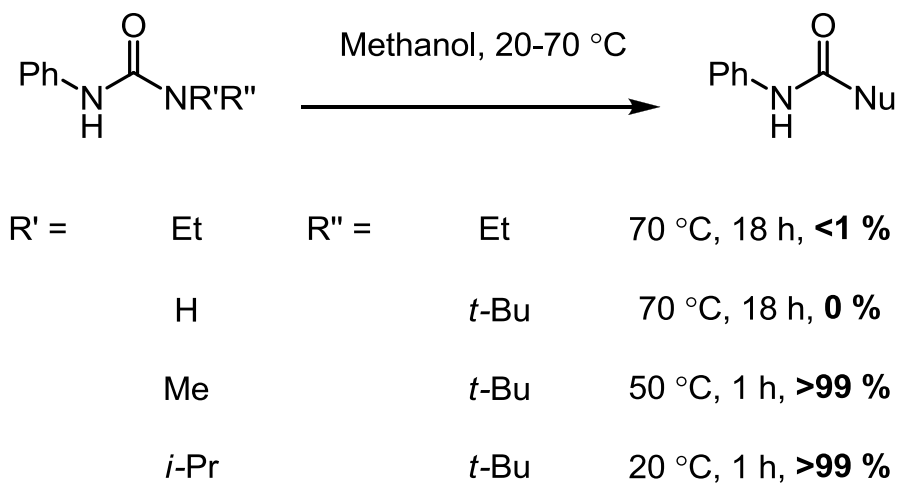

Figure 17. Effect of nitrogen substitution on the methanolysis of aryl ureas

Substrates containing a more hindered nitrogen underwent methanolysis more readily than ureas derived from less hindered amines. Bulky amines such as diisopropyl and tert-butylisopropylamine provided the best yields under mild reaction conditions $\left(20^{\circ} \mathrm{C}\right.$, methanol, $\left.1 \mathrm{~h}\right)$. This reactivity is thought to proceed through either an addition-elimination or elimination-addition pathway (Figure 18). ${ }^{56}$ The latter would generate a reactive isocyanate intermediate.

\footnotetext{
${ }^{55}$ Hutchby, M., Houlden, C. E., Gair Ford, J., Tyler, S. N. G., Gagné, M. R., Lloyd-Jones, G. C., BookerMilburn, K. I. Angew. Chem., Int. Ed. 2009, 48, 8721

${ }^{56}$ Hutchby, M.; Houlden, C. E.; Haddow, M. F.; Tyler, S. N. G.; Lloyd-Jones, G. C.; Booker-Milburn, K. I. Angew. Chem., Int. Ed. 2012, 51, 548
} 


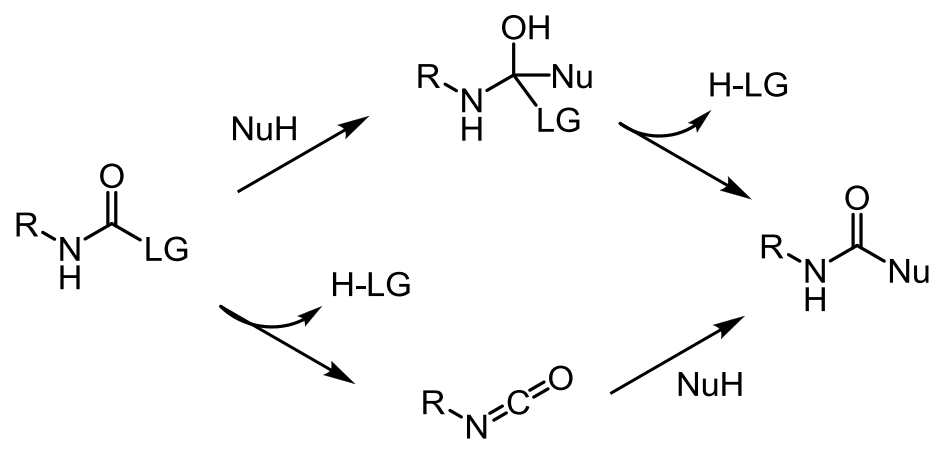

Figure 18. Addition-elimination pathway (top) and elimination-addition pathway with formation of an isocyanate (bottom)

Evaluating the trends seen with different amines as leaving groups, supports the latter reaction pathway. If addition of the nucleophile was the first step, it would not be logical that more hindered amines lead to higher yields (which is the trend observed). Also, the results showing that weaker nucleophiles (thiophenol and phenol) react readily (Figure 19), helps provide support for the generation of a reactive isocyanate intermediate (present in the elimination-addition reaction mechanism).

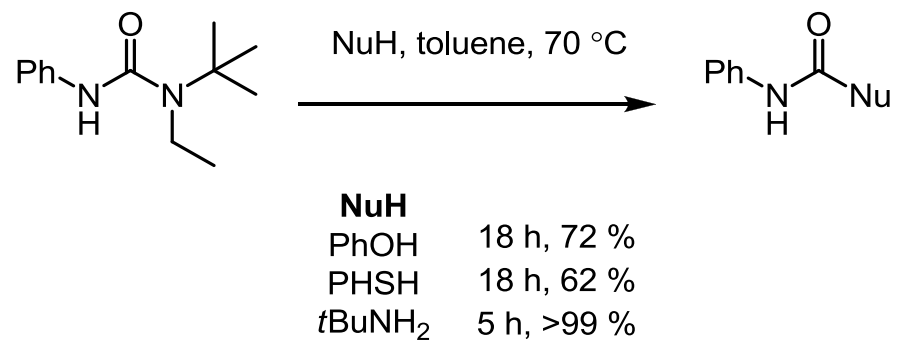

Figure 19: Nucleophilic substitution of various nucleophiles on aryl ureas with hindered disubstituted

The authors are not certain in which way the isocyanate intermediate is generated but they have postulated two ways. Both involve methanol to help facilitate a proton transfer from the $\mathrm{PhNH}$ to the disubstituted nitrogen of the urea (leaving group). What is not certain is if the isocyanate is generated directly from this structure or if it goes through a zwitterionic intermediate first (Scheme 19). 


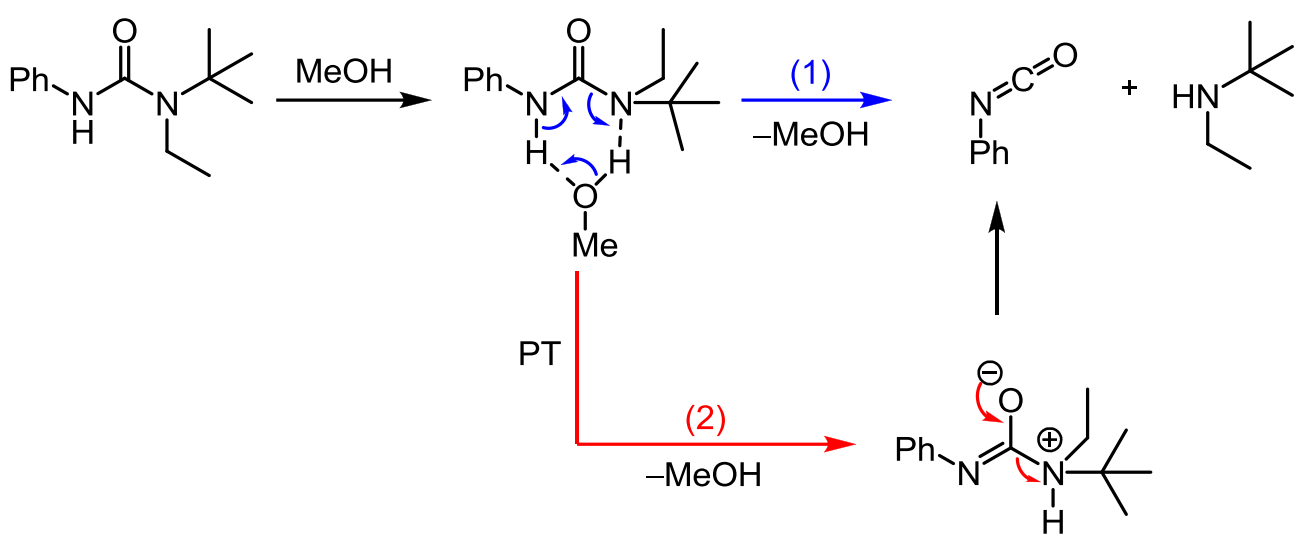

Scheme 19. Two possible pathways for the formation of phenyl isocyanate from hindered urea

To probe the mechanism for isocyanate generation, the trisubstituted phenyl diisopropyl urea was combined with $p$-bromophenylisocyanate in toluene. The products observed are shown in Figure 20, and in fact phenylisocyanate was generated under these conditions with the rate of equilibrium calculated to be faster than that of the initial methanolysis reaction at $35^{\circ} \mathrm{C}$. It was concluded that the $p$-bromophenylisocyanate must facilitate the necessary proton transfer to allow formation of phenylisocyanate and this may account for the faster rate.

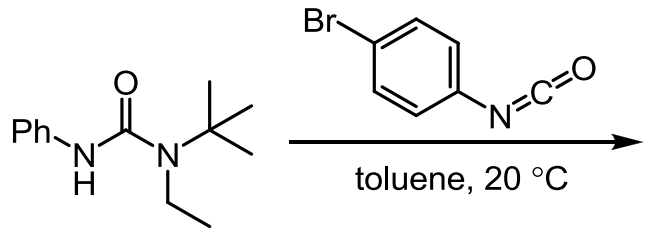<smiles>CCN(C(=O)Nc1ccc(Br)cc1)C(C)(C)C</smiles><smiles>O=C=Nc1ccccc1</smiles>

A

$$
A: B=3: 2
$$<smiles>CCN(C(=O)Nc1ccccc1)C(C)(C)C</smiles><smiles>O=C=Nc1ccc(Br)cc1</smiles>

B

Figure 20. Leaving group exchange reaction with $p$-bromophenylisocyanate to probe the generation of phenyl isocyanate

Finally, the reaction of phenylisocyanate and the trisubstituted urea was examined. Both substrates were combined with equimolar amounts of methanol, ethanol, and $n$-propanol in toluene at $35{ }^{\circ} \mathrm{C}$ (Figure 21). The three products of each reaction had the same distribution in both cases, indicating 
that each reaction is proceeding through an isocyanate. If there had been differences in the product distribution then this could suggest that the trisubstituted urea may be reacting in a different way, but this was not the case.

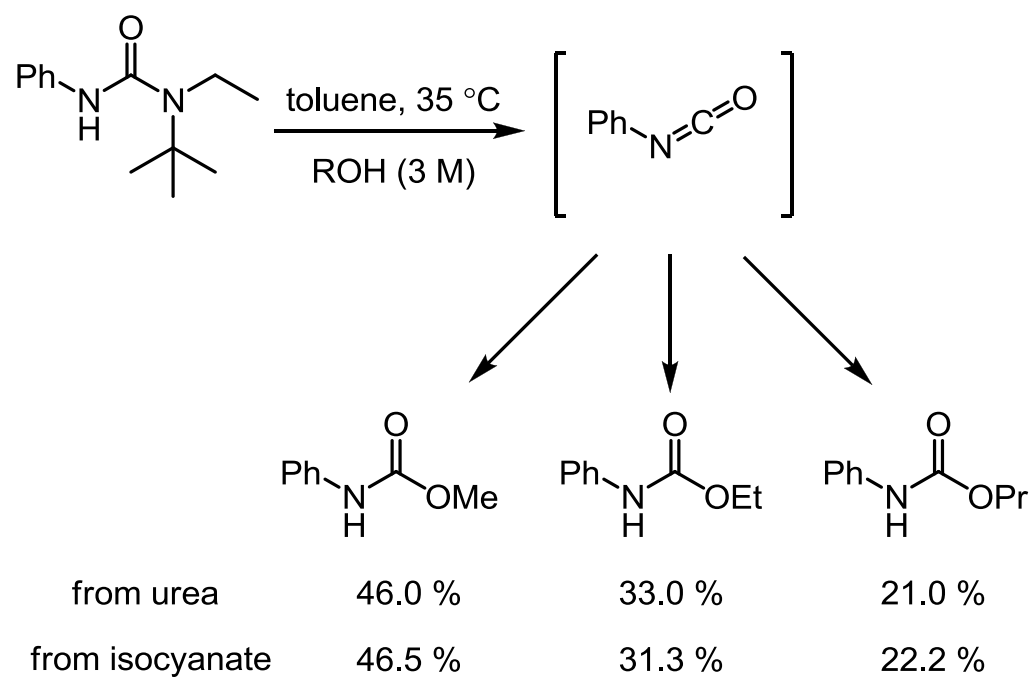

Figure 21: Comparison of distribution of products when trisubstituted urea and phenylisocyanate are reacted with equimolar amounts of alcohols

Lloyd-Jones and Booker-Milburn's study provided insight on the reaction mechanism of the solvolysis of ureas. Much of this knowledge can also be applied to the reactivity of semicarbazones, as they can undergo solvolysis via an imino-isocyanate.

\subsection{Alkene Aminocarbonylation with Hydrazides and Hydrazones}

Early work by Jones provided another example of imino-isocyanate reactivity. ${ }^{57}$ A dipolar triazolidinone derivative was generated from 1,3-dimesitylbenzofuran and 4-phenyltriazoline-3,5dione (Scheme 20). This then able to release phenylisocyanate upon heating to generate an iminoisocyanate. When phenylacetylene is added to the reaction, it undergoes a cycloaddition with the imino-isocyanate to yield an azomethine imine (Scheme 20).

${ }^{57}$ Jones, D. W. J. Chem. Soc., Chem. Commun. 1982, 766 


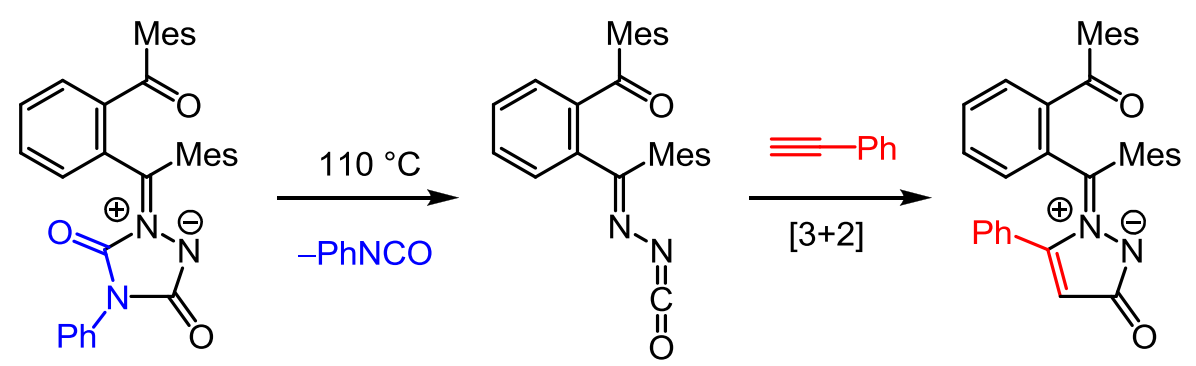

Scheme 20. Alkene amino-carbonylation of imino-isocyanate and phenylacetylene

Within the Beauchemin group, alkene aminocarbonylation has been of great interest. Early work on the intramolecular reactivity gave good yields and demonstrated reactivity with various hydrazides. ${ }^{58}$<smiles>[Y]C(=O)NNC([R])C([R])([R2])CC=C([R])[R]</smiles>

\section{Scheme 21: Intramolecular alkene amino-carbonylation with hydrazides}

The transformation proceeds through an amino-isocyanate intermediate, which is formed upon heating when the leaving group departs. Evidence for a concerted reaction provides support the formation of a reactive amino-isocyanate intermediate. The intermolecular alkene aminocarbonylation with hydrazones was later developed, which involved the formation of an imino-isocyanate intermediate (Figure 22). Milder reaction temperatures were now possible, as well as a broader substrate scope.

${ }^{58}$ Roveda, J.-G.; Clavette, C.; Hunt, A. D.; Whipp, C. J.; Gorelsky, S. I.; Beauchemin, A. M. J. Am. Chem. Soc. 2009, 131, 8740 


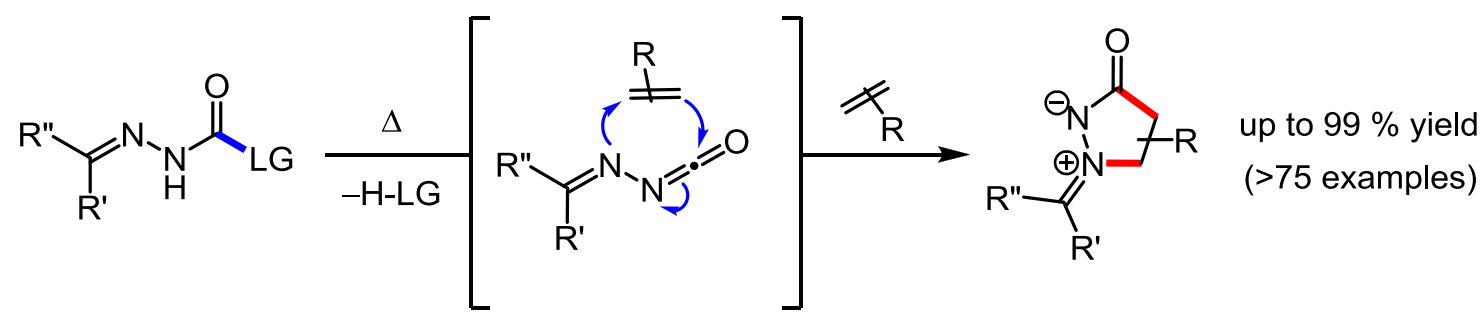

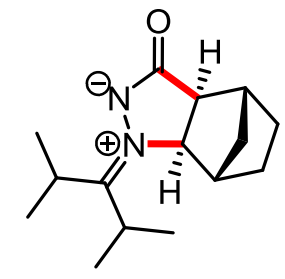

$100{ }^{\circ} \mathrm{C}, 3 \mathrm{~h}, 84 \%$

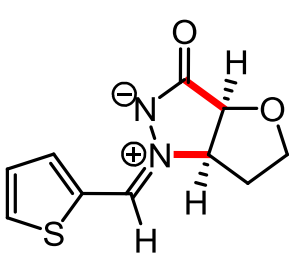

$130{ }^{\circ} \mathrm{C}, 1.5 \mathrm{~h}, 90 \%$

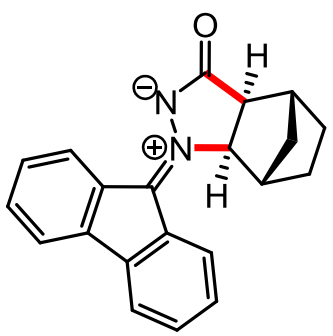

$100{ }^{\circ} \mathrm{C}, 3 \mathrm{~h}, 99 \%$

Figure 22. Intermolecular alkene amino-carbonylation using acyl hydrazones

This was due to the reactivity of the imino-isocyanate (found to be more reactive than the aminoisocyanate).$^{59}$ Temperatures were lowered to $80^{\circ} \mathrm{C}$ in some cases, but this was dependent on the iminoisocyanate and alkene used. It was found that more electron rich and/or strained alkenes gave better yields. Also, more sterically hindered ketones provided better yields, as this minimized the formation of by-products from unwanted side reactions (includes a second [3+2] cycloaddition reaction and imino-isocyanate dimerization).

The built-in leaving group was also found to play a role in how well the reaction worked. It was shown to have an impact on the yield of the reaction (Table 1) as well as the stereocontrol with unsymmetrical hydrazones. ${ }^{59}$ In order to probe this reactivity, new hydrazones needed to be synthesized with various leaving groups.

${ }^{59}$ a) Clavette, C.; Gan, W.; Bongers, A.; Markiewicz, T.; Toderian, A.; Gorelsky, S. I.; Beauchemin, A. M. J. Am. Chem. Soc. 2012, 134, 16111; b) Gan, W.; Moon, P. J.; Clavette, C.; Das Neves, N.; Markiewicz, T.; Toderian, A. B.; Beauchemin, A. M. Org. Lett. 2013, 15, 1890 
Table 1: Effect of Leaving Group on Intermolecular Alkene Aminocarbonylation

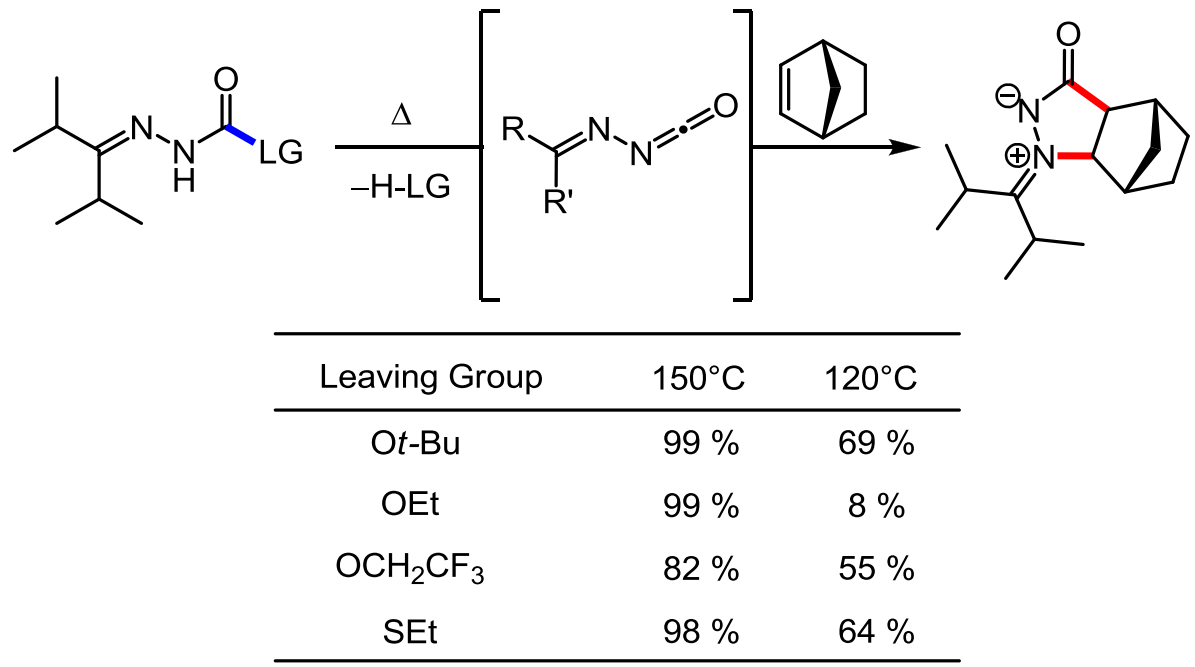

\subsection{Project Objectives for the Synthesis of Hydrazone Derivatives}

The synthesis of hydrazones with various leaving groups proved to be challenging and a more reliable method was needed. Initially, compounds were synthesized by forming the carbazate or semicarbazide, followed by condensation onto a ketone or aldehyde. For sterically hindered ketones, this condensation reaction was low yielding. Furthermore, forming the necessary carbazates and semicarbazides proved challenging, and most were not commercially available.

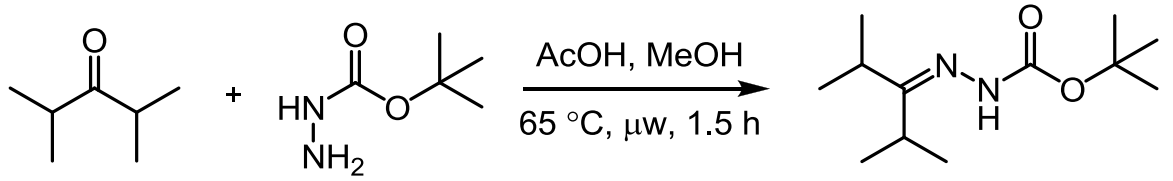

Scheme 22. Synthesis of $t$-butyl hydrazone by condensation of $t$-butylcarbazate and diisopropyl ketone

A solution to this issue was to synthesize these desired hydrazones directly from a common hydrazone precursor, $t$-butylhydrazone is one example (shown in Scheme 22). By simply exchanging one leaving group for another, new hydrazones can be easily synthesized from the same substrate. These first examples of this reactivity within the Beauchemin group used diisopropylamine and thiophenol as nucleophiles (Scheme 23). 

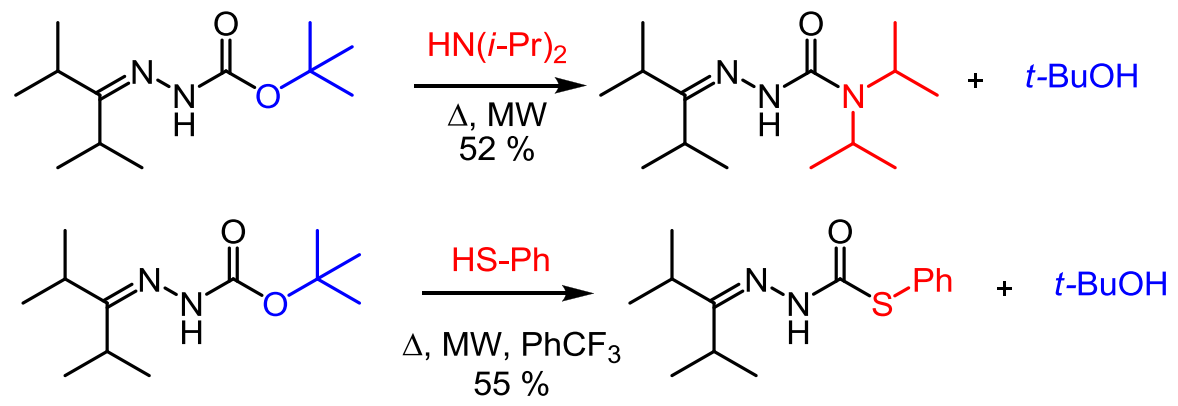

Scheme 23. Solvolysis of tert-butyl hydrazone with (1) diisopropyl amine and (2) thiophenol

Further exploration of this reactivity was performed, including optimization and scope of the reaction. A discussion of these results follows in Chapter 2. In addition to providing a more reliable way to synthesize hydrazone substrates, this new reactivity provided an opportunity to study the formation of imino-isocyanates. Strategically, this proved important due to our alkene aminocarbonylation efforts. In addition, few publications describe the reactivity of imino-isocyanates and given the high impact of recent work on similar systems with isocyanates, ${ }^{23,56}$ there is a need for more information on these interesting reaction intermediates. 


\section{Chapter 2: RESULTS AND DISCUSSION}

\section{1: Previous work on leaving group exchange reactivity with imino-isocyanates}

As noted in Section 1.5 of Chapter 1, the exchange reaction was first performed with thiophenol and $N, N$-diisopropylamine as nucleophiles (Scheme 23). The reaction with $N, N$-diisopropylamine was run neat with excess nucleophile (14 equiv) and required heating using microwave irradiation for 3 minutes at $150{ }^{\circ} \mathrm{C}$. Similarly the reaction with thiophenol was run at $150{ }^{\circ} \mathrm{C}$ in the microwave, although only 5 equiv. of thiophenol was required. Optimization of conditions was later carried out.

Amines were used as nucleophiles in the reaction, and worked well. Optimization of reaction conditions with various amines was carried out by Charlotte Depatie-Sicard. This included the following amines; $n$-hexylamine, tert-butylamine, morpholine, and aniline. The number of equivalents of nucleophile was reduced to 2 equiv. for each of the amines, with a temperature of $120{ }^{\circ} \mathrm{C}$ using microwave irradiation. Longer reaction times generally led to higher isolated yields (Entry 1, 2; Table 2) with the exception of morpholine (Entry 3; Table 2) which showed a slight decrease in yield. 
Table 2. Results of optimization with amines at different reaction times ${ }^{a}$

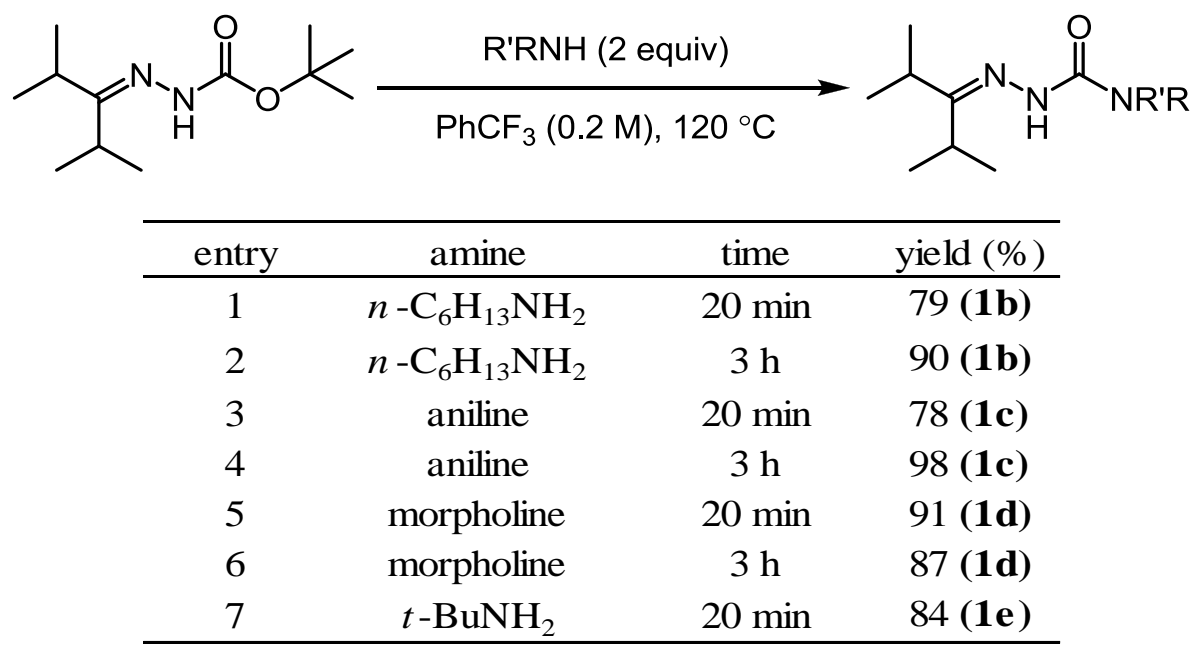

${ }^{a}$ Conditions: hydrazone (1.0 equiv), nucleophile (2 equiv) in $\mathrm{PhCF}_{3}(0.5 \mathrm{M})$, microwave irradiation, time and temperature stated above.

\subsection{Studies with tert-butyl 2-(2,4-dimethylpentan-3-ylidene)hydrazinecarboxylate (1a)}

Most of the studies on the leaving group exchange reaction were carried out using the 2,5dimethylpentan-3-one derived hydrazone with tert-butanol as leaving group (hydrazone 1a). This hydrazone proved to be a great substrate to use for the initial studies as it was easy and inexpensive to synthesize (see Scheme 22). The starting materials were commercially available, and purification was simple, employing recrystallization. This substrate was used for the optimization of the exchange reaction as well as the nucleophile scope. 


\subsubsection{Optimization of reaction conditions using thiols}

Earlier efforts towards the leaving group exchange reaction by Dr. Wei Gan ${ }^{59}$ demonstrated that two thiols (thiophenol and ethanethiol) worked as nucleophiles in the reaction. Thiophenol only worked

in moderate yield (Entry 1; Table 3) while ethanethiol was high yielding (Entry 2; Table 3) due to its higher nucleophilicity.

Table 3. Unoptimized exchange reaction with thiols ${ }^{a}$

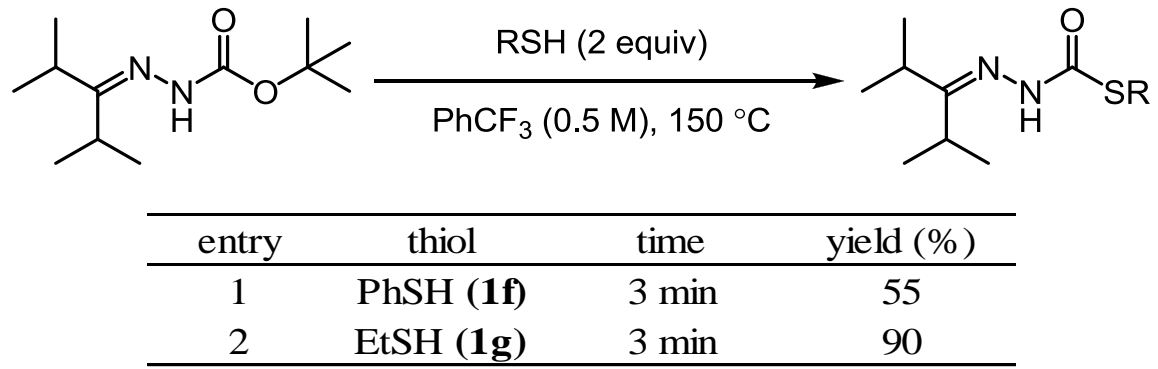

${ }^{a}$ Conditions: hydrazone (1.0 equiv), nucleophile (2 equiv) in $\mathrm{PhCF}_{3}(0.5 \mathrm{M})$, microwave irradiation, time and temperature stated above.

For the optimization of the thiols, ethanethiol was replaced with 1-octanethiol, which is less volatile. Optimization with thiophenol and 1-octanethiol was carried out.

\subsection{1.a Optimization with Thiophenol}

Optimization with thiophenol demonstrated that higher yields could be achieved with microwave irradiation by lowering the temperature (from $150{ }^{\circ} \mathrm{C}$ to $120{ }^{\circ} \mathrm{C}$ ) and lengthening the reaction time (from 3 minutes to 3 hours). Much of the optimization employed the use of an internal standard to provide an NMR yield for the reactions. It was difficult to get an accurate NMR yield due to the lack of unique proton peaks in the product. Two different peaks were used in the determination of the NMR yields, the hydrogen of the phenol ring $\left(\mathrm{H}_{1}\right)$ and the proton on the nitrogen $\left(\mathrm{H}_{2}\right)$. Isolated yields were obtained for results that seemed promising by NMR analysis. 
Decomposition of the hydrazone is thought to occur as reaction times are increased at higher temperatures, most likely occurring through the formation of the imino-isocyanate species. More experiments would need to be conducted to determine exactly how long the reaction times need to be for this decomposition to be observed. Subsequent leaving group comparison studies (Section 2.2.3 of Chapter 2) support the likelihood of facile imino-isocyanate formation under the reaction conditions.

Table 4. Optimization with thiophenol using microwave irradiation ${ }^{a}$

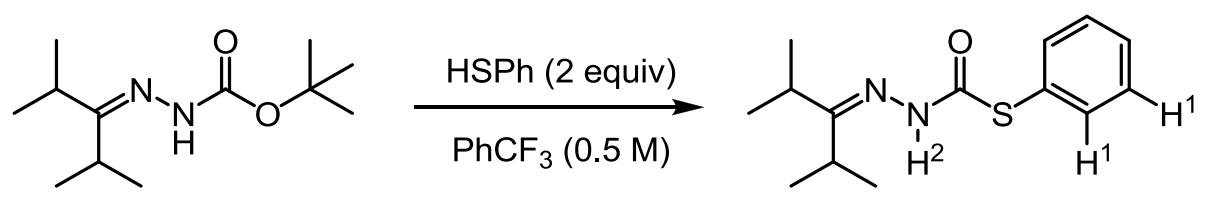

\begin{tabular}{|c|c|c|c|c|c|}
\hline \multirow[t]{2}{*}{ Entry } & \multirow{2}{*}{$\begin{array}{c}\text { Temperature } \\
\left({ }^{\circ} \mathrm{C}\right)\end{array}$} & \multirow[t]{2}{*}{ Time (h) } & \multicolumn{2}{|c|}{ NMR Yield (\%) } & \multirow{2}{*}{$\begin{array}{c}\text { Isolated } \\
(\%)\end{array}$} \\
\hline & & & $\mathrm{H}_{1}$ & $\mathrm{H}_{2}$ & \\
\hline 1 & 150 & 0.05 & 52 & 47 & 51 \\
\hline 2 & 150 & 0.5 & 58 & 49 & \\
\hline 3 & 150 & 1 & 78 & 66 & \\
\hline 4 & 150 & 2 & 75 & 67 & \\
\hline 5 & 150 & 3 & 77 & 72 & 47 \\
\hline 6 & 150 & 4 & 67 & 62 & \\
\hline 7 & 130 & 2 & 65 & 60 & \\
\hline 8 & 120 & 1 & 67 & 62 & 70 \\
\hline 9 & 120 & 2 & / & / & 73 \\
\hline 10 & 120 & 3 & 103 & 65 & 62 \\
\hline 11 & 120 & 4 & 40 & 22 & 62 \\
\hline 12 & 110 & 2 & 58 & 54 & \\
\hline 13 & 100 & 2 & 59 & 54 & 62 \\
\hline
\end{tabular}

${ }^{a}$ Conditions: hydrazone ( 1 equiv), thiophenol (2 equiv) in $\mathrm{PhCF}_{3}(0.5 \mathrm{M})$, microwave irradiation, time and temperature as stated above.

The equivalent of nucleophile was lowered from 5 to 2 equivalents. At $120{ }^{\circ} \mathrm{C}$, a reaction time of 2 hours worked best, to give a yield of $73 \%$ (Entry 9; Table 4).

Interestingly, when this reaction was performed in an oil bath at $100{ }^{\circ} \mathrm{C}$ it was possible to increase the reaction times and observe increased yields, which may be due to the lower heating efficiency 
associated with oil bath heating compared to microwave irradiation. ${ }^{60}$ The actual bulk temperature of the reaction when in the oil bath is most likely less than $100{ }^{\circ} \mathrm{C}$, whereas the temperature of the reaction under microwave irradiation may be higher or equal to $100{ }^{\circ} \mathrm{C}$ (as the temperature is only measured at the surface of the reaction vessel). The results of optimization using conventional heating are presented in Table 5.

Table 5. Optimization with thiophenol using conventional heating<smiles>CC(C)/C(=N/NC(=O)Sc1ccccc1)C(C)C(C)CC(=O)OC(C)(C)C</smiles>

\begin{tabular}{|c|c|c|c|c|}
\hline \multirow[t]{2}{*}{ Entry } & \multirow[t]{2}{*}{ Time (h) } & \multicolumn{2}{|c|}{ NMR Yield $^{b}(\%)$} & \multirow{2}{*}{$\begin{array}{c}\text { Isolated } \\
(\%)\end{array}$} \\
\hline & & $\mathrm{H}_{1}$ & $\mathrm{H}_{2}$ & \\
\hline 1 & 2 & 73 & 51 & \\
\hline 2 & 3 & 78 & 68 & 75 \\
\hline 3 & 4 & 91 & 85 & 70 \\
\hline 4 & 6 & 88 & 80 & 90 \\
\hline 5 & 12 & 95 & 87 & 97 \\
\hline
\end{tabular}

${ }^{a}$ Conditions: hydrazone (1 equiv), thiophenol (2 equiv) in $\mathrm{PhCF}_{3}(0.2 \mathrm{M})$, time and temperature as stated above. ${ }^{b} \mathrm{NMR}$ yield obtained using an internal standard and either $\mathrm{H}_{1}\left(\mathrm{CH}\right.$ of phenyl) or $\mathrm{H}_{2}(\mathrm{~N}-\mathrm{H})$

Using the oil bath, a reaction time of 12 hours led to an isolated yield of $97 \%$ (Entry 5; Table 5). Even after 6 hours at $100{ }^{\circ} \mathrm{C}$, it was possible to obtain a $90 \%$ yield (Entry 4; Table 5). These reaction conditions provided a convenient approach to execute the reaction on larger scale.

\footnotetext{
${ }^{60}$ Kappe, C. O. Angew. Chem., Int. Ed. 2004, 43, 6250
} 


\subsection{1.b Optimization with 1-Octanethiol}

Performing similar reaction using 1-octanethiol as the desired nucleophile lead to a yield of $81 \%$ after 3 hours at $120{ }^{\circ} \mathrm{C}$ (microwave irradiation). Time and temperature studies are summarized in Table 6.

Table 6. Optimization of reaction conditions using 1-octanethiol ${ }^{a}$

\begin{tabular}{ccccc} 
& & & \\
\hline
\end{tabular}

${ }^{a}$ Conditions: hydrazone (1 equiv), 1 -octanethiol (2 equiv) in $\mathrm{PhCF}_{3}(0.2 \mathrm{M})$, microwave irradiation, time and temperature as stated above.

NMR yields were calculated using an internal standard and the distinctive peak from the protons of the methylene carbon adjacent to the sulfur atom. In general, it was observed that the decomposition was minimized in comparison to the thiophenol containing adducts. This is likely due to the higher thermal stability of 1-octanethiol adducts in comparison to the thiophenol substrate (hydrazone 1f). Indeed, thiophenol is a better leaving group, which likely leads to formation of the imino-isocyanate at a lower temperature and subsequent side-reactions (see Section 2.2.3 of Chapter 2). It is also possible that the position of the equilibrium between the imino-isocyanate and the thiol could be different for the two substrates. 


\subsubsection{Nucleophile scope with tert-butanol as leaving group}

Initially, the nucleophile scope consisted of amines ( $t$-butylamine, $n$-hexylamine, morpholine, and aniline), and thiols (ethanethiol, thiophenol, and 1-octanethiol). In order to broaden this scope, new amines were added (isopropylamine and $N, N$-diisopropylamine) as well as alcohols (benzylalcohol and phenol). The table below (Table 7) outlines the results obtained with various nucleophiles.

Table 7: Nucleophile Scope with tert-butyl hydrazone $\mathbf{1 a}^{a}$

\begin{tabular}{|c|c|c|c|c|}
\hline entry & Nuc-H & temp $\left({ }^{\circ} \mathrm{C}\right)$ & time & yield $^{b}(\%)$ \\
\hline 1 & $n-\mathrm{C}_{6} \mathrm{H}_{13} \mathrm{NH}_{2}$ & 120 & $20 \mathrm{~min}$ & 79 (1b) \\
\hline 2 & $i-\mathrm{PrNH}_{2}$ & 120 & $20 \min$ & 83 (1i) \\
\hline $3^{c}$ & $t-\mathrm{BuNH}_{2}$ & 120 & $20 \min$ & 83 (1e) \\
\hline $4^{c}$ & $\mathrm{PhNH}_{2}$ & 120 & $20 \mathrm{~min}$ & 78 (1c) \\
\hline $5^{d}$ & $i-\mathrm{Pr}_{2} \mathrm{NH}$ & 150 & $3 \mathrm{~min}$ & 68(99) (1j) \\
\hline 6 & morpholine & 120 & $20 \mathrm{~min}$ & 91 (1d) \\
\hline 7 & $n-\mathrm{C}_{8} \mathrm{H}_{17} \mathrm{SH}$ & 120 & $3 \mathrm{~h}$ & 82 (1h) \\
\hline 8 & PhSH & 120 & $2 \mathrm{~h}$ & 73 (1f) \\
\hline $9^{e}$ & $\mathrm{BnOH}$ & 150 & $3 \mathrm{~min}$ & 85 (1k) \\
\hline 10 & $\mathrm{PhOH}$ & 150 & $3 \mathrm{~min}$ & 27 (11) \\
\hline
\end{tabular}

${ }^{a}$ Conditions: hydrazone (1.0 equiv), nucleophile (2 equiv), in $\mathrm{PhCF}_{3}(0.2 \mathrm{M})$, microwave irradiation, time and temperature as stated above. ${ }^{b}$ Isolated yields, NMR yield in parentheses. ${ }^{c} \mathrm{PhCF}_{3}(0.5 \mathrm{M}) .{ }^{d} 1.0$ equiv of hydrazone, 14 equiv of nucleophile, neat. ${ }^{e} 5.0$ equiv of nucleophile

A variety of amines worked well, and only required heating to $120{ }^{\circ} \mathrm{C}$ using microwave irradiation (with the exception of $N, N$-diisopropylamine - see discussion in Section 2.2.3). Primary (1hexylamine, isopropylamine, tert-butylamine), secondary (morpholine, $N, N$-diisopropylamine) and aryl amines (aniline) were used. $N, N$-Diisopropylamine only gave a moderate isolated yield compared 
to other amines. This could be due to the steric destabilization of the adduct formed. Any free tertbutanol generated from the starting material could add back to the isocyanate intermediate instead, regenerating starting material. More on hydrazone $\mathbf{1} \mathbf{j}$ ( $N, N$-diisopropylamine) is included in section.

The two thiols included were thiophenol and 1-octanethiol, as mentioned in the previous section. In addition to amines and thiols, the use of alcohols as a nucleophile was also probed. Phenol proved to be a poor nucleophile for the exchange reaction, only giving a yield of $27 \%$ (Entry 10; Table 7). This was not surprising since we already knew that it worked well as a leaving group. ${ }^{59}$ Although, this could have provided a convenient way to synthesize the OPh hydrazone $\mathbf{1 l}$ (used in many alkene aminocarbonylation reaction performed in the lab) had it worked in better yield. Benzylalcohol was a much better nucleophile, and provided a yield of $85 \%$ (Entry 9; Table 7). The ability to swap a tertbutyl group for a benzyl group is also potentially very useful. The overall reaction occurring is the exchange of a Boc protecting group for a Cbz group. Lloyd-Jones and Booker-Milburn have shown a similar transformation with isocyanates..$^{55}$

Overall the alcohols required higher temperatures than the amines, which is not surprising since they are weaker nucleophiles under the reaction conditions. This provided calibration on the exchange reaction and demonstrated that stronger, less hindered nucleophiles provide higher yields.

The nucleophile scope was tested on other hydrazones as well, while keeping the leaving group constant (tert-butanol). Examples of this reactivity with various hydrazones are shown below in Table 8. 
Table 8: Reaction of nucleophiles with various hydrazone substrates ${ }^{a}$

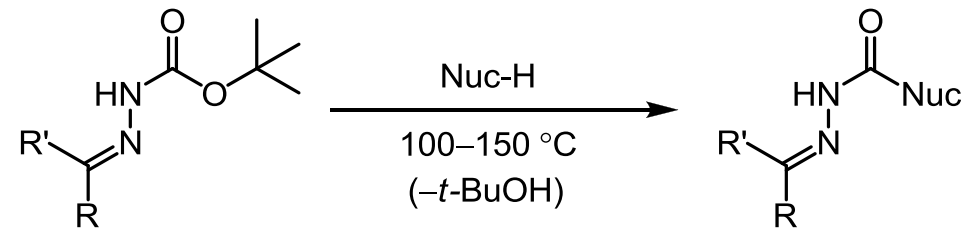

\begin{tabular}{cccccc}
\hline entry & starting material & Nuc-H & temp $\left({ }^{\circ} \mathrm{C}\right)$ & time & yield $^{b}(\%)$ \\
\hline 1 & $i-\mathrm{PrNH}_{2}$ & 100 & $20 \mathrm{~min}$ & $66(\mathbf{2 b})$ \\
2 & & $t-\mathrm{BuNH}_{2}$ & 150 & $30 \mathrm{~min}$ & $75(\mathbf{2 c})$ \\
3 & & $\mathrm{PhNH}_{2}$ & 150 & $30 \mathrm{~min}$ & $72(\mathbf{2 d})$ \\
4 & & $\mathrm{PhOH}$ & 150 & $2 \mathrm{~h}$ & 0 \\
5 & & $\mathrm{PhSH}$ & 150 & $2 \mathrm{~h}$ & $77(\mathbf{2 e})$ \\
\hline 6 & & $n-\mathrm{C}_{6} \mathrm{H}_{13} \mathrm{NH}_{2}$ & 120 & $20 \mathrm{~min}$ & $64(\mathbf{2 g})$ \\
7 & & $n-\mathrm{C}_{6} \mathrm{H}_{13} \mathrm{NH}_{2}$ & 120 & $20 \mathrm{~min}$ & $79(\mathbf{2 i})$ \\
8 & & $\mathrm{PhOH}_{2}$ & 150 & $5 \mathrm{~min}$ & $18(\mathbf{2 j})$ \\
\hline
\end{tabular}

${ }^{a}$ Conditions: hydrazone (1.0 equiv), nucleophile ( 2 equiv), in $\mathrm{PhCF}_{3}(0.2 \mathrm{M})$, microwave irradiation, time and temperature as stated above. ${ }^{b}$ Isolated yields, NMR yield in parentheses.

The entries with the hydrazone with the terminal alkene (Entries 1-5; Table 8) were performed by Dr. Wei Gan and helped show the broad scope of this reactivity. Benzaldehyde (Entry 6; Table 8) and fluorenone (Entry 7; Table 8) derived hydrazones further demonstrated that the exchange reaction works with other hydrazones. The fluorenone hydrazone (2f) showed similar reactivity to hydrazone 1a when $n$-hexylamine was used as nucleophile, with product formation observed at $120{ }^{\circ} \mathrm{C}$. Hydrazones derived from aldehydes, such as benzaldehyde, generally led to lower yields with $n$ hexylamine (only $64 \%$ at $120{ }^{\circ} \mathrm{C}$ compared to $79 \%$ for the fluorenone hydrazone). A similar trend was also observed for the alkene aminocarbonylation reaction with these hydrazones. ${ }^{59}$ Hydrazones derived from bulkier ketones led to higher yields than aldehyde derived hydrazones. This was attributed to the increased difficulty of imino-isocyanate dimerization (see Section 1.3 of Chapter 1) 
when using bulkier ketone derived hydrazones. When less dimerization occurs, higher yields of desired product can be obtained.

The use of alcohols as nucleophiles was briefly touched on earlier when discussing Table 7, where phenol and benzylalcohol were used. Additional alcohols that were studied include $n$-butanol, tertbutanol and 1,3-propanediol, and are displayed in Table 9.

Table 9. Leaving group exchange reaction with various alcohols as nucleophiles ${ }^{a}$

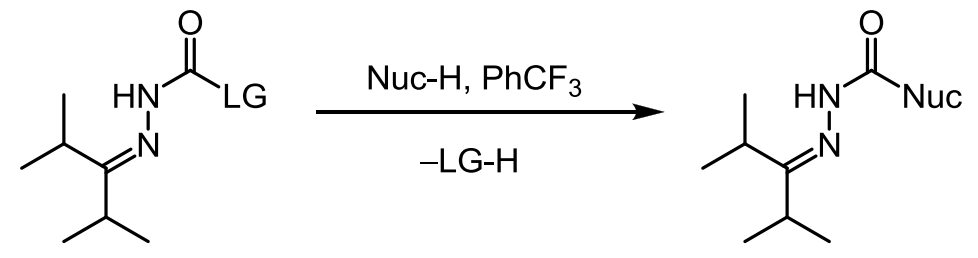

\begin{tabular}{cccccc}
\hline entry & leaving group & nucleophile & temp $\left({ }^{\circ} \mathrm{C}\right)$ & time & $\%$ yield $^{b}$ \\
\hline 1 & $t-\mathrm{BuOH}$ & $\mathrm{BnOH}$ & 150 & $3 \mathrm{~min}$ & $85(\mathbf{1 k})$ \\
2 & $\mathrm{BnOH}$ & $t-\mathrm{BuOH}$ & 150 & $3 \mathrm{~min}$ & $80(\mathbf{1 a})$ \\
3 & $i-\mathrm{Pr}_{2} \mathrm{NH}$ & $n-\mathrm{BuOH}$ & 60 & $3 \mathrm{~h}$ & $65(\mathbf{1 m})$ \\
$4^{c}$ & $i-\mathrm{Pr}_{2} \mathrm{NH}$ & $n-\mathrm{BuOH}$ & 80 & $16 \mathrm{~h}$ & $95(\mathbf{1 m})$ \\
$5^{c}$ & $i-\mathrm{Pr}_{2} \mathrm{NH}$ & $n-\mathrm{BuOH}$ & 80 & $5 \mathrm{~h}$ & $56(\mathbf{1 m})$ \\
$6^{d}$ & $i-\mathrm{Pr}_{2} \mathrm{NH}$ & $1,3-$ propanediol & 80 & $4.5 \mathrm{~h}$ & $62(28)(\mathbf{1 n})$ \\
\hline
\end{tabular}

${ }^{a}$ Conditions: hydrazone (1.0 equiv), alcohol (2 equiv), in $\mathrm{PhCF}_{3}(0.2 \mathrm{M})$, microwave irradiation. ${ }^{b}$ isolated yields ${ }^{c} 5$ equiv alcohol ${ }^{d}$ hydrazone ( 3 equiv), alcohol ( 1 equiv), MeCN $(0.5 \mathrm{M})$, oil bath, isolated yield in

Entry 1 of Table 9 was included in the earlier study on nucleophile scope and complements entry 2 of Table 9. These two entries (1 and 2) demonstrate how it is possible to transform a Boc protecting group into a Cbz protecting group, and vice versa. Entries 3-5 of Table 9 involve $n$-butanol as a nucleophile with $N, N$-diisopropylamine as the leaving group. This combination allowed for reactivity to be observed at a lower temperature $\left(60^{\circ} \mathrm{C}\right)$ than reactions performed with other alcohols. The steric destabilization present in the hydrazone substrate (1j) likely helped to make this possible. This suggests that the imino-isocyanate is reversibly formed under mild reaction conditions, and it is likely that the addition of the alcohol is irreversible at $60{ }^{\circ} \mathrm{C}$. If tert-butanol was used as the leaving group 
then it would be competing with $n$-butanol as the nucleophile. Not surprisingly, as the reaction times were lengthened and heating increased, the yield for the reaction with $n$-butanol was also increased (entry 4 vs entries 3 and 5).

The last entry in Table 9 demonstrated a double substitution reaction. The diol is able to react with two separate hydrazones and essentially link them together. At first only monoaddition was observed, leaving one end of the diol free. This was the case when the reaction was run with hydrazone 11 (-OPh as leaving group). By increasing the temperature and changing to a better leaving group ( $N, N$ diisopropylamine), the double addition product was formed. The leaving group used for this reaction proved very important, since when hydrazone $\mathbf{1 l}(-\mathrm{OPh})$ was used, little desired product and mainly monoaddition was observed. However the use of hydrazone $\mathbf{1 j}$ ( $N, N$-diisopropylamine) lead to formation of the desired product as the major product.. For this reason, and many others, it was very important to study the various leaving groups and see how they compared to one another.

\subsubsection{Leaving group comparison}

In the process of studying the scope of nucleophiles, calibration on the generation of the iminoisocyanate from the tert-butyl leaving group was achieved. It seemed that temperatures of $120-150^{\circ}$ $\mathrm{C}$ were needed in order to form the desired products. Now that there were a number of hydrazones available from the previous study of nucleophiles, it was possible to take a look at the temperatures needed for imino-isocyanate generation for a variety of leaving groups. The nucleophile chosen for this study was $n$-hexylamine, since it is easy to work with, lead to a product with unique peaks in the ${ }^{1} \mathrm{H}$ NMR spectrum to allow for analysis using internal standard, and it provided good yields during the nucleophile scope. Table 10 shows the results from this investigation. 
Table 10: Leaving group comparison with $n$-hexylamine as nucleophile ${ }^{a}$
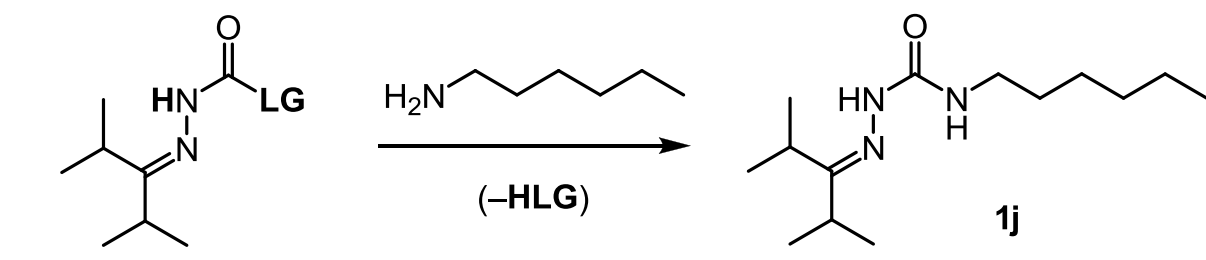

\begin{tabular}{|c|c|c|c|c|}
\hline Entry & Leaving Group & Temp $\left({ }^{\circ} \mathrm{C}\right)$ & Time & Yield $^{b}(\%)$ \\
\hline 1 & $n-\mathrm{C}_{8} \mathrm{H}_{17} \mathrm{SH}$ (1a) & 150 & $20 \mathrm{~min}$ & 98 \\
\hline 2 & $n-\mathrm{C}_{8} \mathrm{H}_{17} \mathrm{SH}$ (1a) & 120 & $20 \mathrm{~min}$ & 98 \\
\hline 3 & $n-\mathrm{C}_{8} \mathrm{H}_{17} \mathrm{SH}$ (1a) & 100 & $20 \mathrm{~min}$ & 51 \\
\hline 4 & $\mathrm{PhSH}$ (1b) & 50 & $20 \mathrm{~min}$ & 95 \\
\hline 5 & $\mathrm{PhSH}$ (1 b) & $\mathrm{rt}$ & $20 \mathrm{~min}$ & 64 \\
\hline 6 & $\mathrm{PhSH}$ (1 b) & $\mathrm{rt}$ & $1 \mathrm{~h}$ & 82 \\
\hline 7 & $\mathrm{PhSH}$ (1b) & $\mathrm{rt}$ & $2 \mathrm{~h}$ & 93 \\
\hline 8 & $\mathrm{PhSH}$ (1 b) & $\mathrm{rt}$ & $4 \mathrm{~h}$ & 99 (99) \\
\hline 9 & $t-\mathrm{BuNH}_{2}(\mathbf{1 c})$ & 100 & $20 \mathrm{~min}$ & 45 \\
\hline 10 & $t-\mathrm{BuNH}_{2}(\mathbf{1 c})$ & 120 & $20 \mathrm{~min}$ & 92 \\
\hline 11 & $\mathrm{PhNH}_{2}$ (1d) & 100 & $30 \mathrm{~min}$ & 41 \\
\hline 12 & $\mathrm{PhNH}_{2}$ (1d) & 100 & $1 \mathrm{~h}$ & 62 \\
\hline 13 & $\mathrm{PhNH}_{2}$ (1d) & 100 & $2 \mathrm{~h}$ & 87 \\
\hline 14 & $\mathrm{PhNH}_{2}$ (1d) & 100 & $3 \mathrm{~h}$ & 91 \\
\hline 15 & morpholine (1e) & 100 & $1 \mathrm{~h}$ & 99 \\
\hline 16 & $i-\mathrm{Pr}_{2} \mathrm{NH}(\mathbf{1 f})$ & 40 & $20 \mathrm{~min}$ & 89 \\
\hline 17 & $i-\operatorname{Pr}_{2} \mathrm{NH}(\mathbf{1 f})$ & $\mathrm{rt}$ & $20 \mathrm{~min}$ & 52 \\
\hline 18 & $i-\mathrm{Pr}_{2} \mathrm{NH}(\mathbf{1 f})$ & $\mathrm{rt}$ & $2 \mathrm{~h}$ & $84(84)$ \\
\hline 19 & $i-\mathrm{Pr}_{2} \mathrm{NH}(\mathbf{1 f})$ & $\mathrm{rt}$ & $4 \mathrm{~h}$ & 91 \\
\hline 20 & $\mathrm{BnOH}(\mathbf{1 g})$ & 150 & $20 \mathrm{~min}$ & 94 \\
\hline 21 & $\mathrm{BnOH}(\mathbf{1 g})$ & 120 & $20 \mathrm{~min}$ & 38 \\
\hline 22 & $t-\mathrm{BuOH}(\mathbf{1 h})$ & 120 & $20 \mathrm{~min}$ & 95 \\
\hline 23 & $t-\mathrm{BuOH}(\mathbf{1 h})$ & 100 & $20 \mathrm{~min}$ & 40 \\
\hline 24 & $\mathrm{PhOH}(\mathbf{1 i})$ & $\mathrm{rt}$ & $20 \mathrm{~min}$ & $91(99)$ \\
\hline
\end{tabular}

${ }^{a}$ Conditions: hydrazone (1 equiv), $n-\mathrm{C}_{6} \mathrm{H}_{13} \mathrm{NH}_{2}$ (2 equiv), $\mathrm{PhCF}_{3}(0.2 \mathrm{M}$ ), for reactions requiring heat, microwave irradiation was used. ${ }^{b} \mathrm{NMR}$ yields using internal standard, isolated yields in parentheses

In order to compare the leaving groups, all hydrazones were reacted with the same nucleophile, $n$ hexylamine. By using the same nucleophile in every reaction and comparing the temperatures required 
for product formation, a relative ranking of the leaving groups could be achieved. In general, hydrazones that were low yielding in their formation during the previous study (nucleophile scope) were able to generate the imino-isocyanate under milder conditions (Entries 4-8, 17-19, 24, Table 10). The better nucleophiles (generally amines), proved to be poor leaving groups (with exceptions) since they required higher temperatures to form the imino-isocyanate.

Interesting results were discovered during this investigation. Hydrazone $\mathbf{1 l}$ (-OPh, Entry 24, Table 10) was found to react with $n$-hexylamine at room temperature. This was a ground breaking result, and it complemented the previous results observed with phenol as a nucleophile. Since phenol was found to be such a great leaving group, it should therefore not work well as a nucleophile (which was the case as a yield of only $27 \%$ was obtained - see Table 7, Entry 10). Hydrazone $\mathbf{1 b}$ (thiophenol as leaving group) proved to be a very substrate as well, with the exchange reaction occurring at room temperature also (Entries 5-8; Table 10). The reaction times were slightly longer than those needed when using phenol as leaving group. After 1 hour, a yield of $82 \%$ was obtained (Entry 6; Table 10) and after 4 hour the reaction was quantitative (Entry 8; Table 10) when using thiophenol as the leaving group. Another leaving group that demonstrated room temperature reactivity was $N, N$-diisopropylamine (Entries 15-18; Table 10). It proved to have a similar reactivity to the thiophenol-derived hydrazone, being able to yield $93 \%$ of product after 4 hours (Entry 18; Table 10). This result with $N, N$ diisopropylamine is in agreement with the results of Lloyd-Jones and Booker-Milburn's study on the methanolysis of hindered ureas, ${ }^{55}$ which found that sterically hindered secondary amines work well as leaving groups allowing for mild reaction conditions to be used for the hydrolysis. The substrates studied were ureas that were able to generate isocyanates, upon departure of a leaving group. $N, N$ Diisopropylamine was one of the leaving groups used in the study and it was shown to work well but required slight heating. More hindered amines lead to isocyanate generation at $20^{\circ} \mathrm{C}$ (such as isopropyl tert-butylamine). In a 2011 publication, Lloyd-Jones and Booker-Milburn discussed this concept of hindered secondary amines as leaving groups in more depth, ${ }^{56}$ although this work focused on the use 
of amides (instead of ureas) that generate ketenes upon leaving group departure. The results shown above show that the extension of this approach is possible for semicarbazones and help explain why $\mathrm{N}, \mathrm{N}$-diisopropylamine is a good leaving group. The reasoning involves the orientation of the amine and its lone pairs in relation to the adjacent carbonyl (see below). Normally, the conformation is locked and rotation restricted due to lone pair participation in resonance with the carbonyl.

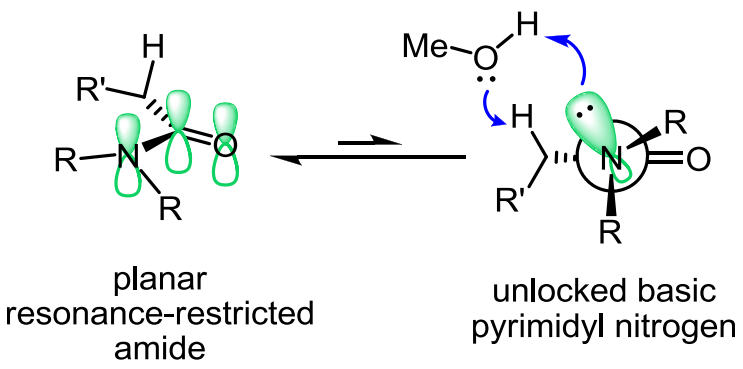

This makes the amine relatively planar and prevents rotation around the $\mathrm{N}-\mathrm{CO}$ bond. As the substitution on the nitrogen increases in steric bulk, the nitrogen begins to become pyramidal and this allows for increased rotation around the $\mathrm{N}-\mathrm{CO}$ bond, since participation of the lone pair in resonance with the carbonyl becomes more difficult. At the same time, the basicity of the nitrogen increases the likelyhood of proton transfer steps, as illustrated with $\mathrm{MeOH}$ in Equations 11 and 12. The secondary amine can then depart as a neutral molecule and allow for the formation of the reactive heterocumulene intermediate (ketenes from hindered amides, isocyanates in the case of ureas and imino-isocyanates in the case of semicarbazones).
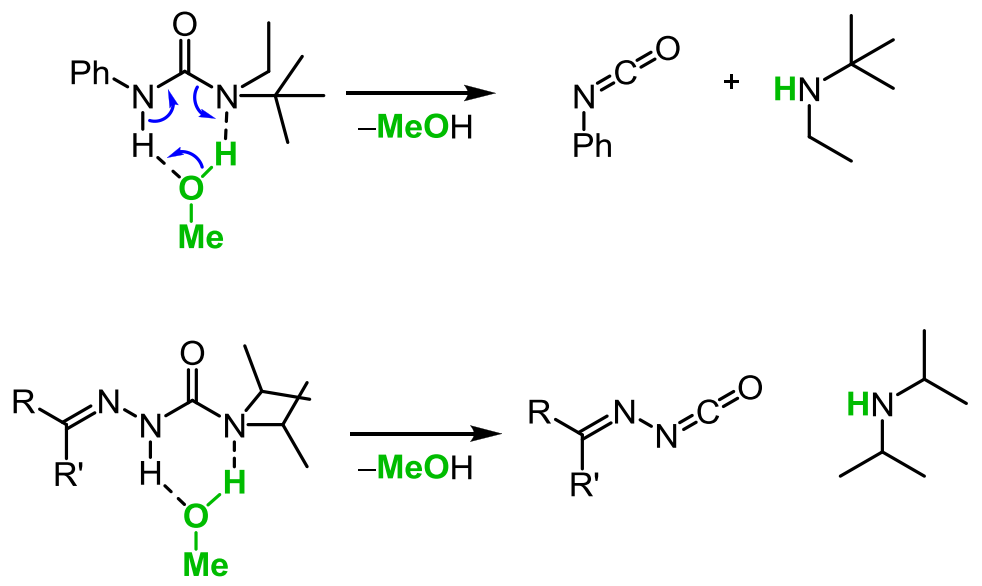
Overall the factors helping to drive this reaction are the decreased rotational barrier, and the steric decompression with the departure of leaving group.

\subsection{Mechanism of imino-isocyanate formation}

It is important to note that the mechanism for the formation of the imino-isocyanate is not fully understood. Although, previous studies on the effects of the addition of nitrogen bases to the alkene aminocarbonylation reaction helped to provide some insight. ${ }^{61}$ A study in the group by Kaitlyn Lavergne looked at the effects of a variety of nitrogen-containing bases and found that tertiary bases such as triethylamine, DABCO, and DBU had a significant effect on the yield of the alkene aminocarbonylation reaction. It was hypothesized that the base helped mediate the proton transfer between the N-H adjacent to the carbonyl and the heteroatom of the leaving group. It is suggested by Lloyd-Jones and Booker-Milburn, that this could proceed through a concerted or stepwise mechanism. ${ }^{54}$

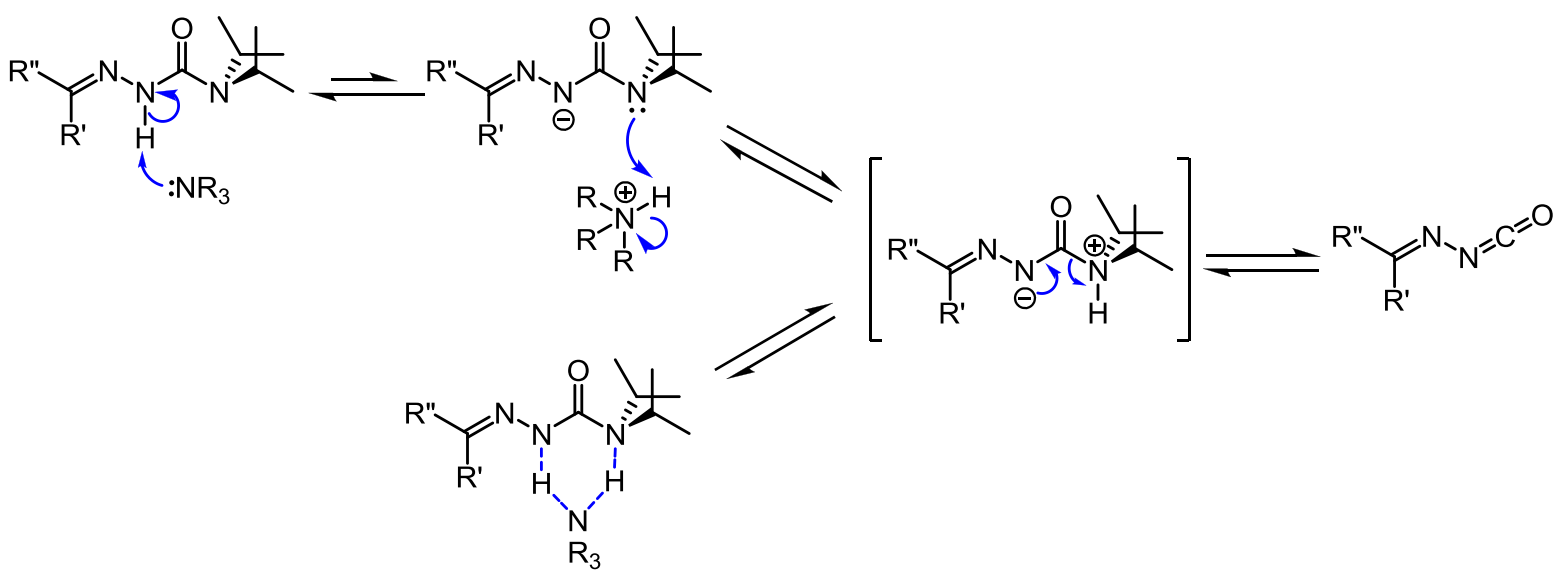

Scheme 24: Formation of the imino-isocyanate via either a concerted (bottom) or step-wise mechanism (top)

\footnotetext{
${ }^{61}$ Lavergne, K. Investigation into Catalytic Intermolecular Aminocarbonylation of Alkenes with Iminoisocyanates. Honours Thesis, University of Ottawa, 2012.
} 
Studying the leaving group exchange reaction with amines (in particular $n$-hexylamine) under room temperature conditions indicated that an excess of amine is necessary. When 2 equivalents of $n$ hexylamine is combined with a hydrazone containing the - OPh leaving group (such as hydrazone 1i) the reaction is complete in 20 minutes with all of the starting material consumed (Entry 1, Table 11). As the number of equivalents of amine drops, the reaction time needs to be extended and even then, the yields are not as high as when 2 equivalents of amine is used (Entries 2-4, Table 11).

Table 11: Room temperature leaving group exchange with various equivalents of $n$-hexylamine

\begin{tabular}{ccccc} 
Entry & Equiv & Solvent & Time & \% yield NMR \\
\hline 1 & 2 & $\mathrm{PhCF}_{3}(0.2 \mathrm{M})$ & $20 \mathrm{~min}$ & 98 \\
2 & 1.1 & $\mathrm{DCM}_{(0.2 \mathrm{M})}$ & $20 \mathrm{~min}$ & 66 \\
3 & 1 & $\mathrm{PhCF}_{3}(0.2 \mathrm{M})$ & $1.5 \mathrm{~h}$ & 74 \\
4 & 1 & $\mathrm{PhCF}_{3}(0.5 \mathrm{M})$ & $1.5 \mathrm{~h}$ & 77
\end{tabular}

${ }^{a}$ Conditions: hydrazone (1 equiv), $n-\mathrm{C}_{6} \mathrm{H}_{13} \mathrm{NH}_{2}$ (2 equiv), solvent as stated. ${ }^{b} \mathrm{NMR}$ yields using internal standard

This reaction was also carried out with excess hydrazone to see how this would affect the yield (Eq 13). Using $n$-hexylamine as the limiting reagent, a yield of $78 \%$ was obtained. This is comparable to the yields previously obtained when using less than 2 equiv. of amine (Entries 2-4, Table 11)

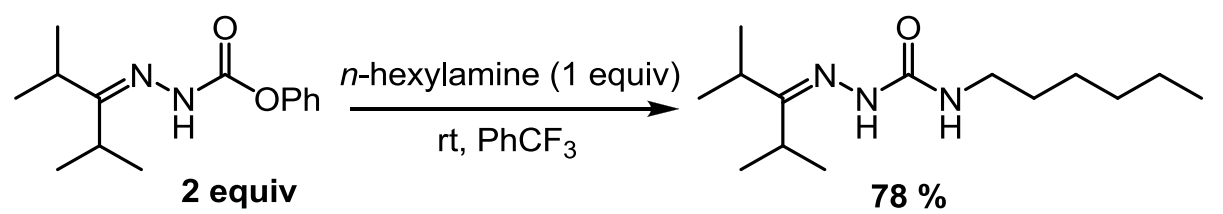

It would be interesting to see how the yields of the reaction would be affected when the reaction times are longer than 1.5 hour, although unfortunately this was not further studied. 


\subsection{Hydrazone structure scope}

With the knowledge of which leaving groups react with $n$-hexylamine at room temperature it was possible to explore this reactivity with new nucleophiles and new hydrazones. Other primary and secondary amines were used as nucleophiles at room temperature (with phenol as leaving group). The reactivity proved to be general enough to allow the use of a variety of ketone and aldehyde derived hydrazones (Figure 23).

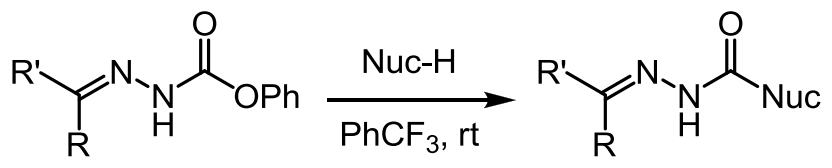<smiles>C=CCC/C(C)=N/NC(=O)Nc1ccccc1</smiles>

$20 \mathrm{~min}, 83 \%(4 \mathrm{a})$

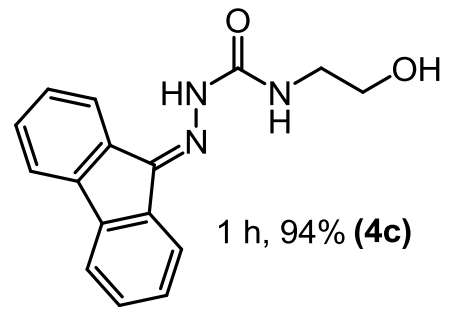<smiles>CCN(CC)C(=O)NN=C(C(C)C)C(C)C</smiles>

$1 \mathrm{~h}, 58 \%(4 \mathrm{~b})$<smiles>O=C(N/N=C/c1ccc(C(F)(F)F)cc1)N1CCC(c2ccccc2)CC1</smiles><smiles>CCCCCCNC(=O)N/N=C/c1ccccc1</smiles>

Figure 23: Room temperature reactivity with various nucleophiles and hydrazones

Hydrazone 4a demonstrates the compatibility with alkenes, and compounds $\mathbf{4 d}$ and $\mathbf{2 e}$ show room temperature reactivity works with aldehyde-derived hydrazones. Additional secondary amines not included in the initial scope were diethylamine and 4-phenylpiperidine and were found to react with 
the hydrazones at room temperature. The use of ethanolamine as nucleophile demonstrated the preference for reaction with amines at room temperature over alcohols.

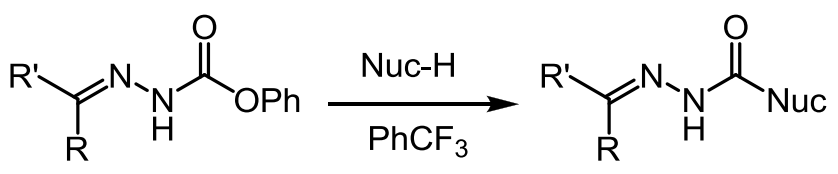

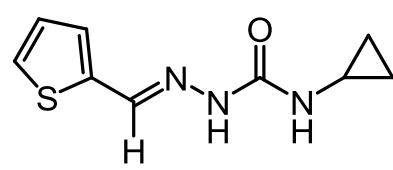

$4 \mathrm{~h}, 80^{\circ} \mathrm{C}, 99 \%^{\mathrm{e}}(\mathbf{4 e})$

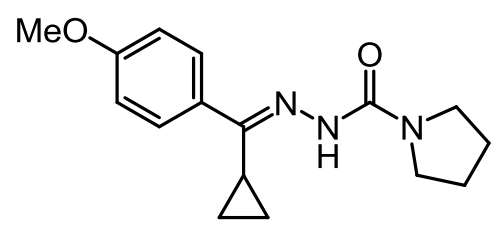

$30 \min , 120^{\circ} \mathrm{C}, 99 \%(4 f)$

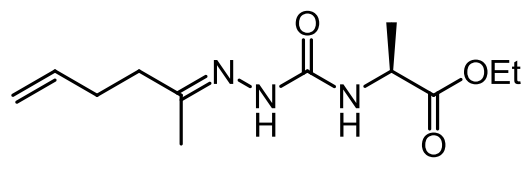

$30 \min , 100{ }^{\circ} \mathrm{C}, 71 \%^{\mathrm{C}} \mathbf{( 4 g )}$

Figure 24. Leaving group exchange reaction using a variety of hydrazones and nucleophiles

Additional examples of the possible hydrazone structures are shown in Figure 24. Compound $\mathbf{4 e}$ was derived from 2-thiophene aldehyde and the reaction with cyclopropylamine proved to be challenging at first. The synthesis of the starting material worked smoothly, with the condensation of phenylcarbazate and 2-thiophene aldehyde proceeding at room temperature with no acid catalysis. The exchange reaction with cyclopropylamine was attempted at room temperature but provided no reactivity. After switching to heated conditions the reaction proceeded quantitatively. Compound $\mathbf{4 f}$ also required heating although this was due to the use of tert-butanol as leaving group. The reason for this choice of leaving group was due to difficulty when using phenyl carbazate to synthesize the hydrazone. Switching to the use of tert-butyl carbazate allowed for an increase in isolated yield from $5 \%$ (phenyl carbazate) to $40 \%$ (tert-butyl carbazate). The condensation reaction is higher yielding in 
some cases when using tert-butyl carbazate since it is not as sensitive to heating. When using phenylcarbazate it is possible to generate the imino-isocyanate once the acyl hydrazone is formed. Even heating to $65^{\circ} \mathrm{C}$ is enough for a small amount of phenol to be generated. Once this happens, the free phenol may not add back to the isocyanate therefore leaving the isocyanate available to react with water or other iminio-isocyanate molecules. It is also possible for the carbazate itself to decompose under heating by generating an amino-isocyanate (Scheme 25). Indeed, when condensation reactions are run with phenylcarbazate, phenol is commonly seen as a byproduct in the reaction.

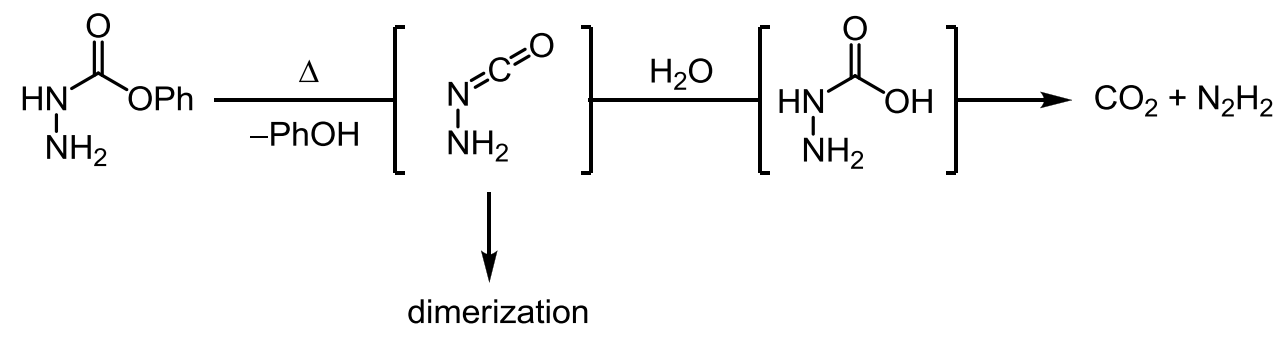

Scheme 25. Decomposition of phenylcarbazate via formation of an amino-isocyanate upon heating

Compound $\mathbf{4 g}$ (Figure 24) provides an example of an aminoester as a nucleophile, in this case L-alanine ethylester. Since working from the hydrochloride salt, added base was needed. Normally the reaction conditions do not require the addition of base. Surprisingly, room temperature reactivity was not observed and the reaction required heating.

\subsection{Diisocyanates}

With the high number of diisocyanates used in industry, ${ }^{1}$ it was a logical step to look into the iminoisocyanate variants. Having two reactive imino-isocyanate groups on one molecule opens up the possibility for double addition of nucleophiles and even for the formation of novel polyurethanes. 
Prevalent diisocyanates were used as inspiration for the synthesis of the di-imino-isocyanates. Toluenediisocyanate (TDI) and hexamethylenediisocyanate (HDI) are two of the most used diisocyanates. ${ }^{1,10}$ 1,3-bis(Isocyanatomethyl)benzene (XDI) resembles the second substrate more closely than TDI, with the methylene carbon replaced by a nitrogen.<smiles>Cc1ccc(N=C=O)cc1N=C=O</smiles>

TDI<smiles>O=C=NCc1cccc(CN=C=O)c1</smiles>

XDI<smiles>O=C=NCCCCCCCN=C=O</smiles>

HDI

Figure 25. Three common industrial di-isocyanates; toluene di-isocyanate, $m$-xylylene di-isocyanate, hexamethylene di-isocyanate

The approach to the synthesis of the di-imino-isocyanates is the same as with most other acyl hydrazones used. Starting from the appropriate ketone or aldehyde, condensation of either tert-butyl carbazate or phenyl carbazate generates blocked di-imino-isocyanates. For the substrate similar to HDI, 2,5-hexanedione was used. The aliphatic di-isocyanates both share a six carbon backbone, but the di-imino-isocyanate groups are positioned on different carbons along the chain (carbons 2 and 5)

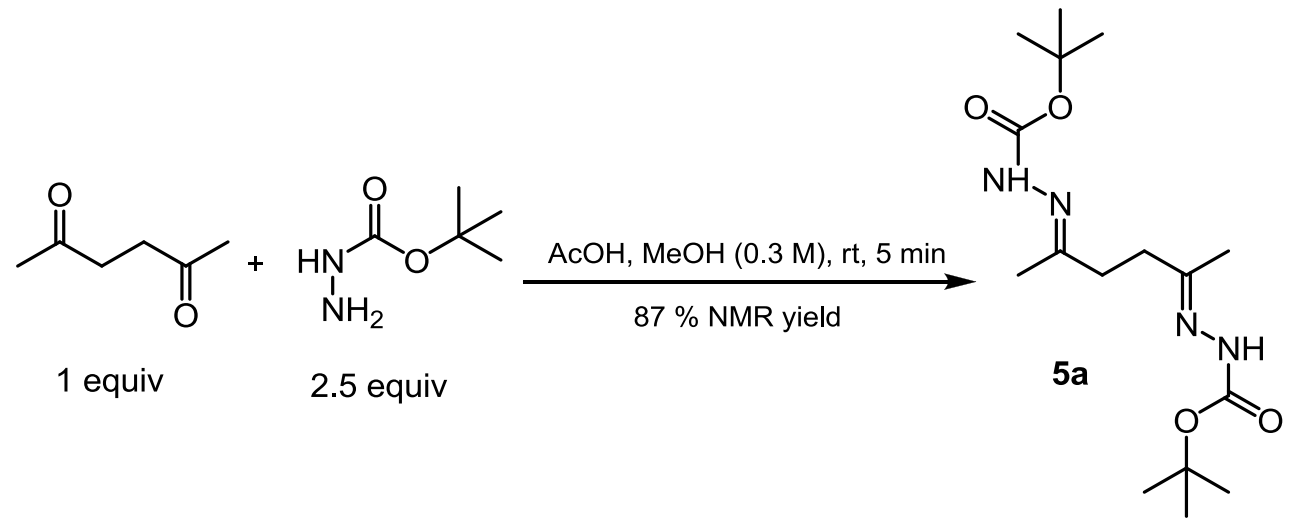

The condensation reaction was first completed with tert-butylcarbazate. The reaction was found to proceed at room temperature. As the diketone was added to the reaction flask containing the carbazate 
in methanol, a white solid began to slowly precipitate. As acetic acid was added the whole contents of the flask appeared to solidify. The condensation occurred almost immediately at room temperature, and filtration of the crude mixture easily afforded the desired product. The dihydrazone generated is essentially a blocked di-imino-isocyanate.

The stability of this dihydrazone is questionable in certain solvents. The addition of deuterated chloroform produced a distinct colour change from clear, colourless solution to a clear, orange solution. This colour change was paired with a messy ${ }^{1} \mathrm{H}$ NMR spectrum which most likely contained decomposition products of the dihydrazone. The compound is believed to be acid sensitive since chloroform with added potassium carbonate did not lead to a change in colour, even after storing for a few hours at room temperature. Benzene- $d_{6}$ and DMSO- $d_{6}$ are compatible NMR solvents and did not lead to any decomposition.

The next dihydrazone was synthesized using phenylcarbazate with the hopes of probing the room temperature reactivity $(\mathrm{Eq} 15)$.<smiles>CC(=O)CCC(C)=O</smiles>

1 equiv<smiles>NNC(=O)Oc1ccccc1</smiles>

2.5 equiv

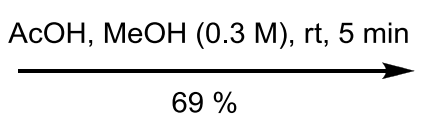

$69 \%$

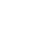

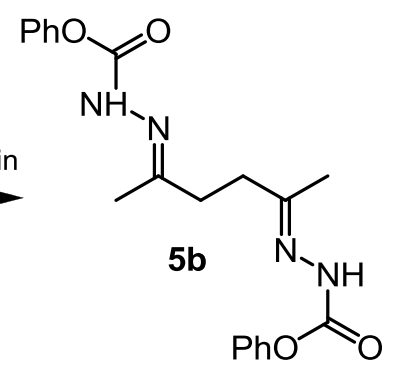

The condensation proceeded similarly to the previous one, with product crashing out at room temperature. Solubility was poor, and NMR analysis was performed in DMSO- $d_{6}$.

The exchange reaction was carried out on dihydrazone $\mathbf{5 b}$ with $n$-hexylamine as nucleophile (Eq 16). This reaction gave a yield of $96 \%$ for the disubstituted product (shown in Eq 16), mono-substitution was not observed. A colour change was noticed as soon as $n$-hexylamine was added, similar to the 
reaction run with hydrazone $\mathbf{1 l}(\mathrm{OPh}$ leaving group). Dichloromethane was used as solvent for this reaction as solubility of the starting material was higher than in trifluorotoluene, the usual solvent of choice.

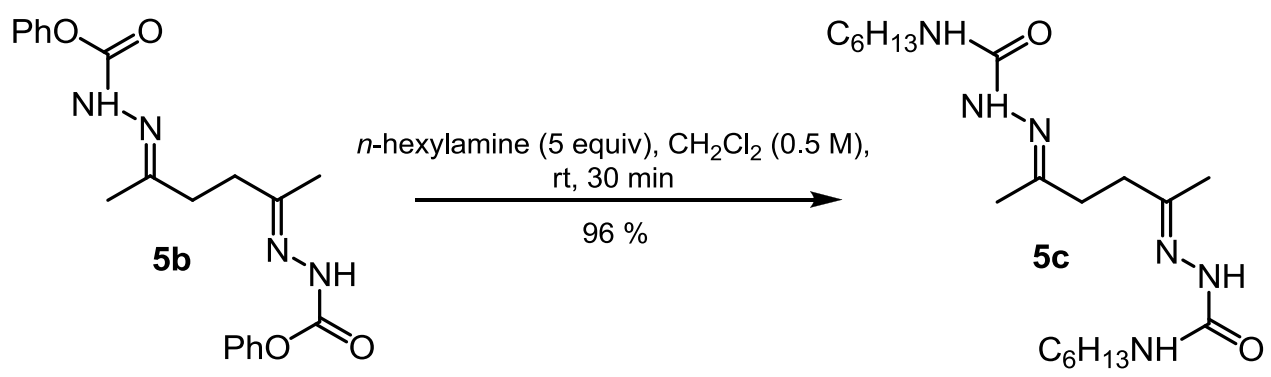

After the success of $n$-hexylamine as nucleophile, the use of a diamine was investigated. Hexamethylenediamine was combined with the dihydrazone $\mathbf{5 b}$ at room temperature. This produced a noticeable colour change after the addition of the diamine and generated a sticky oil after stirring for 1 hour. Starting material had been consumed according to TLC analysis, and a new spot had appeared. The oil produced was difficult to manipulate (was thought to be the polymerization product) and purification was not completed.

\subsection{Other $N$-substituted isocyanates: amido-isocyanates}

Other nitrogen substituted isocyanate precursors were briefly studied. By reaction either phenyl carbazate or tert-butylcarbazate with benzoylchloride, a new substrate (6a) for the leaving group exchange reaction was generated. This hydrazide has the potential to generate acyl-substituted aminoisocyanates (amido-isocyanates). Both the tert-butyl and OPh (hydrazide 6a) derivatives were synthesized. Working with the $\mathrm{OPh}$ derivative allowed for the room temperature reactivity to be probed. When $n$-hexylamine was used as a nucleophile and combined with hydrazide $6 \mathbf{a}$ at room temperature, limited reactivity was observed (Entry 1, Table 12). 
Table 12. leaving group exchange reaction with the acyl substituted imino-isocyanate substrate ${ }^{a}$

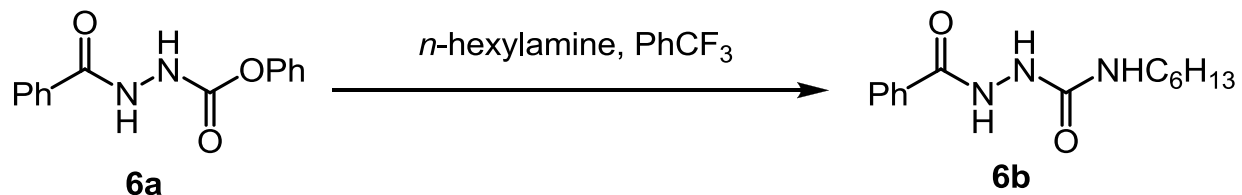

\begin{tabular}{cccccc}
\hline entry & equivalents of nuc & temp $\left({ }^{\circ} \mathrm{C}\right)$ & time & additive & $\%$ yield \\
\hline 1 & 2 & $\mathrm{rt}$ & $4 \mathrm{~d}$ & none & 23 \\
2 & 2 & 60 & $1 \mathrm{~h}$ & none & 23 \\
3 & 2 & 60 & $1 \mathrm{~h}$ & DMAP $(0.3 \mathrm{eq})$ & 38 \\
4 & 2 & 80 & $1 \mathrm{~h}$ & none & 63 \\
5 & 5 & 80 & $1 \mathrm{~h}$ & none & 94 \\
6 & 2 & 100 & $1 \mathrm{~h}$ & none & 96 \\
\hline
\end{tabular}

${ }^{a}$ Conditions: hydrazone (1 equiv), $n-\mathrm{C}_{6} \mathrm{H}_{13} \mathrm{NH}_{2}$ (equiv stated), $\mathrm{PhCF}_{3}(0.2 \mathrm{M}$ ), for reactions requiring heat, microwave irradiation was used. ${ }^{b}$ NMR yields using internal standard.

Some product formation was seen but it was $<5 \%$ after 1 hour at room temperature. If the reaction was left for 4 days at room temperature, the yield increased to 23\% (Entry 1, Table 12). By increasing the reaction temperature to $80{ }^{\circ} \mathrm{C}$ and utilizing microwave irradiation, a yield of $63 \%$ was obtained (Entry 4, Table 12). Further increase in temperature to $100{ }^{\circ} \mathrm{C}$ lead to a yield of $96 \%$ (Entry 6, Table 12). If the number of equivalents of $n$-hexylamine was increased to five instead of two, when heating to $80{ }^{\circ} \mathrm{C}$, a much higher yield of $94 \%$ could be obtained (Entry 5, Table 12). In addition to using $n$ hexylamine, diethylamine was also tested in this reaction (Eq 17).<smiles>CCN(CC)C(=O)NNC(=O)Nc1ccccc1</smiles>

By irradiating hydrazide $\mathbf{6 a}$ at $100{ }^{\circ} \mathrm{C}$ for 1 hour with diethylamine (2 equiv.), an isolated yield of 86 $\%$ was obtained (Eq 17). In order to see reactivity with the tert-butyl leaving group higher temperatures would be necessary, and therefore this substrate was not studied further. 


\subsection{Studies on the Alkylation of hydrazones and imino-isocyanate formation}

Studies with the methylated hydrazones provide support for the imino-isocyanate intermediate. In order to further investigate the mechanism for the exchange reaction and more specifically the formation of the imino-isocyanate, these new hydrazones were synthesized. The goal was to alkylate the $-\mathrm{NH}$ in hopes that it would prevent imino-isocyanate formation and therefore hinder the leaving group exchange reaction. By using this substituted hydrazone and subjecting it to exchange reaction conditions with $n$-hexylamine, it was possible to gain support for the formation of the proposed iminoisocyanate intermediate. Substitution should prevent the formation of the imino-isocyanate (since the nitrogen would need to become positively charged) and therefore no reactivity should be observed. If on the other hand, reactivity is still observed, then this would suggest an addition-elimination pathway (see Figure 18) where formation of an imino-isocyanate is not required.

A semicarbazone with -OPh as leaving group was chosen for the test so that it could be conducted at room temperature. First attempt at methylation involved the use of $n$-butyl lithium and iodomethane. A colour change was observed as soon as the $n$-BuLi was added. Examination of the crude ${ }^{1} \mathrm{H}$ NMR and TLC showed multiple products and as well as phenol. The deprotonation of the nitrogen of the hydrazone likely caused the formation of the imino-isocyanate since the hydrazone that was used had $-\mathrm{OPh}$ as leaving group. New conditions were investigated for the methylation of the hydrazones. Literature precedence for the methylation of the hydrazone with tert-butanol as leaving group was uncovered. Lubell had shown the successful alkylation of the hydrazone shown in Eq 18. ${ }^{53}$
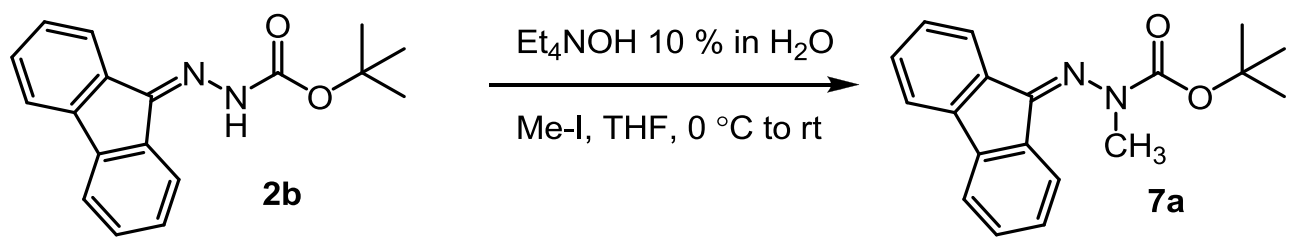
The alkylation worked well: the results were repeated and a quantitative yield was obtained. The next step was to transfer these reaction conditions to hydrazone $\mathbf{3 g}(-\mathrm{OPh})$. The fluorenone version was used in order to compare results with the tert-butyl hydrazone. The methylation of hydrazone $\mathbf{3 g}$ under the same conditions used for hydrazone $\mathbf{2 b}$, led to the formation of $\mathbf{7 b}$ in $40 \%$ yield.

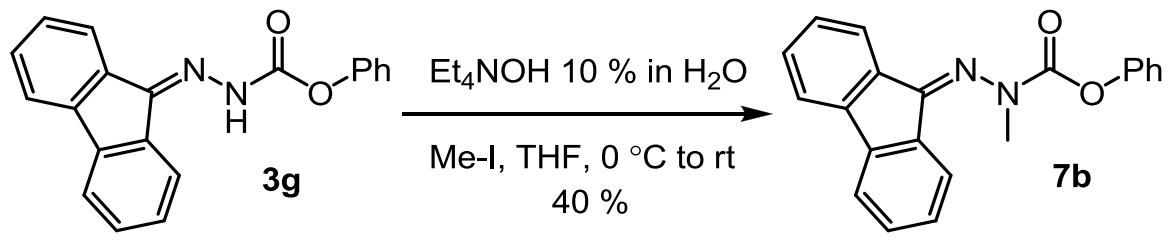

Experimentation with different sources of $\mathrm{Et}_{4} \mathrm{NOH}$ was carried out. Initially, the pentahydrate was utilized and provided great results with the fluorenone hydrazone. In an attempt to move away from water (in hopes of increasing the yield with the $-\mathrm{OPh}$ substrate) a solution of $\mathrm{Et}_{4} \mathrm{NOH}$ in methanol was used. This reagent lead to the generation of an unwanted product. The methanol reacted with the hydrazone, likely through the iminio-isocyanate intermediate generated under the basic reaction conditions. This produced hydrazone 1k, with methanol as a leaving group and no alkylation observed (Eq 20).

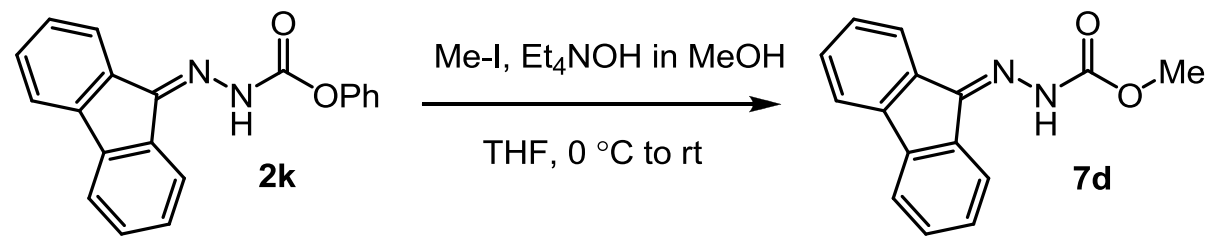

The next source of $\mathrm{Et}_{4} \mathrm{NOH}$ was a $25 \%$ solution in water. This source worked as well as the pentahydrate and was chosen for the alkylation of fluorenone hydrazone with bromoacetamide. Hydrazone 3g was combined with $\mathrm{Et}_{4} \mathrm{NOH}$ and bromoacetamide (Eq 21). The desired alkylated product was obtained (after flash chromatography) in $62 \%$ yield. This demonstrated that less active electrophiles also worked as reagents for this reaction. 
<smiles>CC(C)(C)OC(=O)NN=C1c2ccccc2-c2ccccc21</smiles>

$2 \mathrm{~h}$

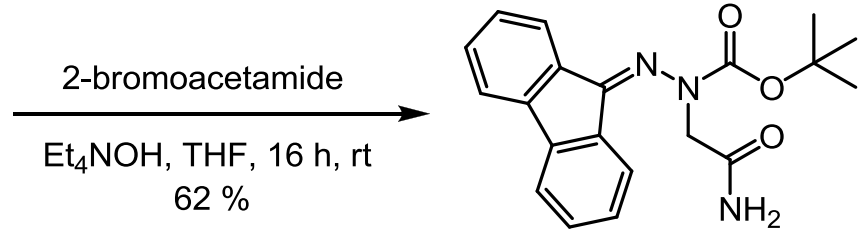

7c

With methylated hydrazones in hand, it was possible to test out the leaving group exchange reaction with the hydrazones (Table 13, Eq 22). First, hydrazone $\mathbf{7 b}$ was combined with $n$-hexylamine at room temperature. After 20 min no reaction had occurred and starting material remained unreacted. In an attempt to push the reaction forward, the reaction was carried out at $100{ }^{\circ} \mathrm{C}$ using microwave irradiation. The starting material was recovered in $84 \%$ yield along with very little product $(1.7 \%$ isolated). Heating the reaction to $200{ }^{\circ} \mathrm{C}$ resulted in mainly decomposition. A messy crude ${ }^{1} \mathrm{H}$ NMR led to an attempt to isolate starting material and product, and only lead to isolation of phenol.

Table 13. Leaving group exchange reaction with methylated hydrazone substrate

\begin{tabular}{|c|c|c|c|c|}
\hline Entry & Time & Temperature $\left({ }^{\circ} \mathrm{C}\right)$ & Product yield (\%) & Comments \\
\hline 1 & $30 \mathrm{~min}$ & rt & 0 & crude ${ }^{1} \mathrm{H}$ NMR $0 \%$ conversion of SM \\
\hline 2 & $30 \mathrm{~min}$ & 100 & 1.7 & recovered $84 \%$ starting material \\
\hline 3 & $30 \mathrm{~min}$ & 200 & ---- & crude ${ }^{1} \mathrm{H}$ NMR mostly decomposition, isolated phenol \\
\hline
\end{tabular}

Next, hydrazone 7a was combined with $n$-hexylamine at $120^{\circ} \mathrm{C}(\mathrm{Eq} 22)$. No product was observed by NMR after leaving the reaction for 20 minutes. It was possible to recover $78 \%$ of the starting material for the reaction. 


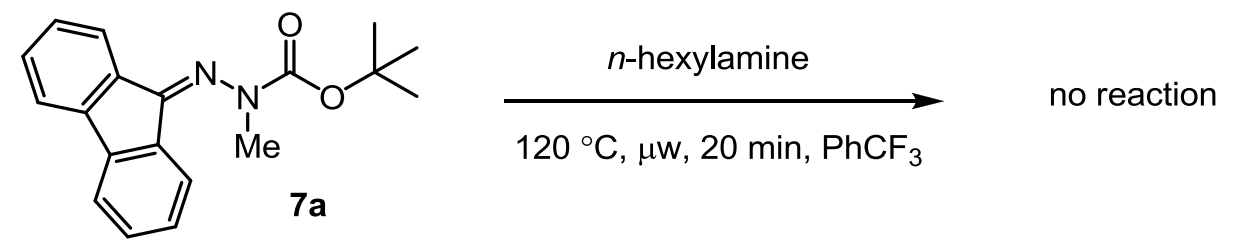

Finally, one last reaction was run with the methylated hydrazones. Hydrazone $\mathbf{7 b}$ was combined with norbornene and heated under microwave irradiation at $120^{\circ} \mathrm{C}$ for 2 hours (Eq 23). No conversion of starting material to product was observed, only starting material and reagents was present in the crude NMR.
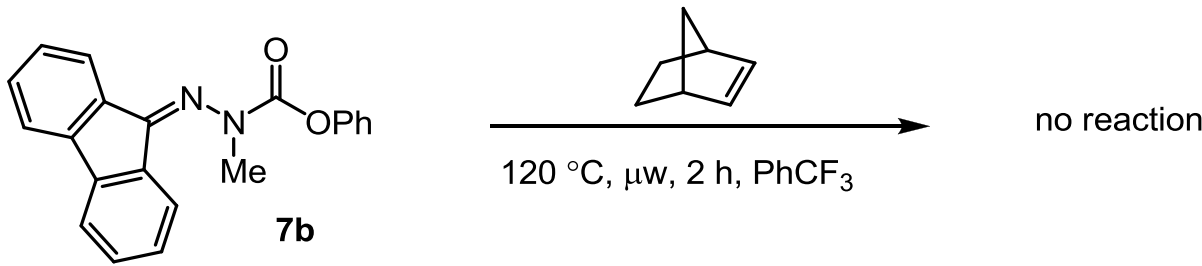

$120^{\circ} \mathrm{C}, \mu \mathrm{w}, 2 \mathrm{~h}, \mathrm{PhCF}_{3}$

These results were very important and helped provide support for the formation of the imino-isocyanate intermediate. Although this is not direct evidence for imino-isocyanate formation, it does suggest that an addition-elimination pathway is difficult and that mild exchange reaction conditions may require formation of the imino-isocyanate in order to proceed. There is still much that can be done with the alkylated hydrazones. The results obtained thus far are positive and help support the formation of the imino-isocyanate as a reactive intermediate in the leaving group exchange reaction.

\section{Chapter 3: CONCLUSIONS}

\subsection{Project Summary and future work}

A simple yet useful exchange reaction has been developed that allows for the synthesis of various hydrazones starting from simpler precursors. The nucleophile scope is broad and included amines 
(primary and secondary), thiols, and alcohols. A variety of hydrazone structures are compatible with the reactivity including hydrazones derived from aldehydes and ketone that are aromatic or aliphatic. The expansion of this reactivity to include di-hydrazones, opens up the possibility for development of substrates for industrial applications in the isocyanate industry.

Continuing studies on the mechanism for the formation of the reactive imino-isocyanate intermediate may help determine the exact pathway. Many findings, such as the results with the methylated hydrazones, support the formation of the proposed imino-isocyanate and their importance for achieving this reactivity under mild reaction conditions. Further studies with various alkylating agents could provide very interesting new structures and help shed light on the formation of the imino-isocyanate. This could be accomplished by pushing the reaction with the alkylated hydrazone and $n$-hexylamine to see at what point product formation is observed.

In the future, it will be possible to look into applications that could benefit from the ability to access varied hydrazone structures easily from simple precursors, due to the ease at which leaving groups can be exchanged.

\subsection{Claims to original research}

1) Development of exchange reaction involving imino-isocyanate intermediate to allow for the derivatization of hydrazones

2) Development of nitrogen analogues of blocked isocyanates.

\subsection{Publications and presentations from this work}

1) Garland, K.; Gan, W.; Depatie-Sicard, C.; Beauchemin, A. M. Org. Lett. 2013, 15, 4074 
2) Garland, K.; Gan, W.; Depatie-Sicard, C.; Clavette, C.; Beauchemin, A. M. $96^{\text {th }}$ Canadian Chemistry Conference and Exhibition - Quebec City, May 29, 2013. Poster presentation

3) Garland, K.; Gan, W.; Depatie-Sicard, C.; Clavette, C.; Beauchemin, A. M. Ottawa Carleton Chemistry Institute Day (OCCI Day) - Ottawa, May 16, 2013. Oral presentation

4) Garland, K.; Gan, W.; Depatie-Sicard, C.; Clavette, C.; Beauchemin, A. M. Synthesis Day University of Ottawa, Ottawa, June 7, 2012. Poster presentation

5) Garland, K.; Gan, W.; Depatie-Sicard, C.; Clavette, C.; Beauchemin, A. M. Ottawa Carleton Chemistry Institute Day (OCCI Day) - May 18, 2012. Poster presentation 


\section{Chapter 4: EXPERIMENTAL}

General Information. Purification of reaction products was carried out by flash column chromatography using silica gel $(40-63 \mu \mathrm{m})$, unless otherwise noted. Analytical thin layer chromatography (TLC) was performed on aluminum or glass, cut to size. Visualization was accomplished with UV light followed by staining with a potassium permanganate solution or cerium molybdate solution, and heating.

${ }^{1} \mathrm{H}$ NMR and ${ }^{13} \mathrm{C}$ NMR spectra were recorded on Bruker AVANCE $300 \mathrm{MHz}$ and $400 \mathrm{MHz}$ spectrometers at ambient temperature, unless otherwise indicated. Spectral data was reported in ppm using solvent as the reference $\left(\mathrm{CDCl}_{3}\right.$ at $7.27 \mathrm{ppm}, \mathrm{C}_{6} \mathrm{D}_{6}$ at $7.15 \mathrm{ppm}$ or DMSO-d $\mathrm{d}_{6}$ at $2.50 \mathrm{ppm}$ for ${ }^{1} \mathrm{H} \mathrm{NMR}$ and $\mathrm{CDCl}_{3}$ at 77.0 ppm, $\mathrm{C}_{6} \mathrm{D}_{6}$ at 128.39 or DMSO- $\mathrm{d}_{6}$ at 39.43 for ${ }^{13} \mathrm{C}$ NMR). ${ }^{1} \mathrm{H}$ NMR data was reported as: multiplicity (ap $=$ apparent, $\mathrm{br}=$ broad, $\mathrm{s}=$ singlet, $\mathrm{d}=$ doublet, $\mathrm{t}=$ triplet, $\mathrm{q}=$ quartet, quint $=$ quintet, $\mathrm{sext}=$ sextuplet, sept $=$ septuplet, $\mathrm{m}=$ multiplet $)$, integration and coupling constant(s) in $\mathrm{Hz}$.

Infrared (IR) spectra were obtained with neat thin films on a sodium chloride disk and were recorded on a Bomem Michelson 100 Fourier transform infrared spectrometer (FTIR). High-resolution mass spectroscopy (HRMS) was performed on a Kratos Concept-11A mass spectrometer with an electron beam of $70 \mathrm{ev}$ at the Ottawa-Carleton Mass Spectrometry Centre.

Microwave reactions were performed using a Biotage Initiator Eight microwave reactor and Biotage microwave vials.

Materials. Unless otherwise noted, all commercially available materials were purchased from commercial sources and used without further purification.

\section{Preparation of Hydrazones}

\section{General procedure 1}

Procedure taken from Leighton and coworkers. ${ }^{62}$ To a round bottom flask charged with stirrer were added the carbazate, followed by methanol, the carbonyl compound, and acetic acid. The reaction was refluxed for the time specified, cooled to room temperature, and concentrated under reduced pressure. Purification by flash chromatography or recrystallization gave the corresponding hydrazone.

tert-Butyl 2-(2,4-dimethylpentan-3-ylidene)hydrazinecarboxylate, ${ }^{63}$ phenyl 2-(2,4-dimethylpentan-3ylidene)hydrazinecarboxylate, ${ }^{63}$ tert-butyl 2 -benzylidenehydrazinecarboxylate, ${ }^{64}$ phenyl 2benzylidenehydrazinecarboxylate, ${ }^{65}$ tert-butyl-2-(9H-fluoren-9-ylidene)hydrazinecarboxylate, ${ }^{66}$ and phenyl-2-(9H-fluoren-9-ylidene)hydrazinecarboxylate63 were prepared according to literature procedures.

${ }^{62}$. Berger, R.; Duff, K.; Leighton, J. L. J. Am. Chem. Soc. 2004, 126, 5686

${ }^{63}$. Clavette, C.; Gan, W.; Bongers, A., Markiewicz, T.; Toderian, A.; Gorelsky, S.; Beauchemin, A. M. J. Am. Chem. Soc. 2012, 134, 16111

${ }^{64}$. (a) Melendez, R. E.; Lubell, W. D. J. Am. Chem. Soc. 2004, 126, 6759. (b) Nun, P.; Martin, C.; Martinez, J.; Lamaty, F. Tetrahedron 2011, 67, 8187

${ }^{65}$. Gan, W.; Moon, P. J.; Clavette, C.; Das Neves, N.; Markiewicz, T.; Toderian, A. B.; Beauchemin, A. M. Org. Lett. 2013, 15, 1890

${ }^{66}$. Garcia-Ramos, Y.; Proulx, C.; Lubell, W. D. Can. J. Chem. 2012, 90, 985 


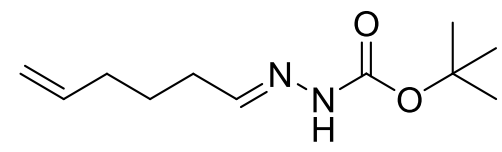

tert-Butyl 2-(hex-5-enylidene)hydrazinecarboxylate ( $2 a$ - substrate for Table 8 )

Hexen-1-ol was oxidized to hex-5-enal according to a procedure previously reported by the Mukai group. ${ }^{67}$ Title compound was then synthesized according to general procedure 1 using tert-butyl carbazate (1.02 $\mathrm{g}$, $7.68 \mathrm{mmol})$ and crude mixture of hex-5-enal $(0.979 \mathrm{~g}, 9.98 \mathrm{mmol})$. Observed a mixture of $E$ and $Z$ isomers in 3.6:1 ratio, respectively. This mixture was purified by flash chromatography (30\% ethyl acetate/hexanes) and isolated as a white solid (1.38 g, $65 \%$ yield). $\mathrm{R}_{f} 0.36$ (30\% ethyl acetate/hexanes); ${ }^{1} \mathrm{H}$ NMR (400 MHz, $\left.\mathrm{CDCl}_{3}\right) *$ denotes minor isomer $\delta \mathrm{ppm} 7.69(\mathrm{~s}, 1 \mathrm{H}), 7.14(\mathrm{t}, J=5.2 \mathrm{~Hz}, 1 \mathrm{H}), * 6.61(\mathrm{t}, J=5.2 \mathrm{~Hz}, 1 \mathrm{H}), 5.77$ (tdd, $J=6.8 \mathrm{~Hz}, 13.2 \mathrm{~Hz}, 12.1 \mathrm{~Hz}, 1 \mathrm{H}), 5.04-4.92(\mathrm{~m}, 2 \mathrm{H}), 2.29(\mathrm{td}, J=5.8,1.5 \mathrm{~Hz}, 2 \mathrm{H}), 2.09-2.03(\mathrm{~m}$, $2 \mathrm{H}), * 1.66(\mathrm{~m}, J=7.2 \mathrm{~Hz}, 2 \mathrm{H}), 1.59(\mathrm{~m}, J=8.0 \mathrm{~Hz}, 2 \mathrm{H}), * 1.51(\mathrm{~s}, 9 \mathrm{H}), 1.48(\mathrm{~s}, 9 \mathrm{H}) ;{ }^{13} \mathrm{C} \mathrm{NMR}(100 \mathrm{MHz}$, $\left.\mathrm{CDCl}_{3}\right) \delta \mathrm{ppm} 152.9(\mathrm{C}), 147.0(\mathrm{C}), * 146.0(\mathrm{C}), 137.9(\mathrm{CH}), * 137.3(\mathrm{CH}), * 115.9\left(\mathrm{CH}_{2}\right), 115.1\left(\mathrm{CH}_{2}\right), 81.0$ $(\mathrm{CH}), 33.2\left(\mathrm{CH}_{2}\right)$, *33.0 $\left(\mathrm{CH}_{2}\right), 31.6\left(\mathrm{CH}_{2}\right), 28.2\left(\mathrm{CH}_{3}\right), 25.9\left(\mathrm{CH}_{2}\right), * 25.5\left(\mathrm{CH}_{2}\right), * 25.0\left(\mathrm{CH}_{2}\right)$; IR (film) 3241, 3078, 2983, 2934, 2865, 1710, 1641, 1539, 1360, 1254, 1166, 1048, 1017, 904, 866, $763 \mathrm{~cm}^{-1}$; LRMS $\mathrm{m} / \mathrm{z}$ (relative intensity) 57.0715 (100\%), 41.0384 (23.9\%), 29.0399 (17.7\%), 58.0534 (12.7\%), 39.0233 $(9.2 \%)$.<smiles>C=CCC/C(C)=N/NC(=O)Oc1ccccc1</smiles>

Phenyl 2-(hex-5-en-2-ylidene)hydrazinecarboxylate (4h - substrate for Figure 23)

Synthesized according to general procedure 1 using 5-hexen-2-one $(0.589 \mathrm{~g}, 6.00 \mathrm{mmol})$, phenyl carbazate $(0.761 \mathrm{~g}, 5.00 \mathrm{mmol})$, acetic acid $(10 \mathrm{drops})$, methanol $(12.5 \mathrm{~mL}), 16 \mathrm{~h}$, reflux. Purification by flash chromatography (20\% ethyl acetate/petroleum ether) afforded the desired product $(0.445 \mathrm{~g}, 40 \%)$, clear, colourless oil, as a mixture of isomers (1:3.8). $\mathrm{R}_{f} 0.25$ (30\% ethyl acetate/petroleum ether); ${ }^{1} \mathrm{H}$ NMR (300 $\left.\mathrm{MHz}, \mathrm{C}_{6} \mathrm{D}_{6}\right) \delta \mathrm{ppm} 7.89(\mathrm{br} \mathrm{s}, 1 \mathrm{H}), 7.37-7.32(\mathrm{~m}, 2 \mathrm{H}), 7.22-7.15(\mathrm{~m}, 3 \mathrm{H})$, 5.86-5.74 (m, 1H), 5.12-4.96 (m, $1 \mathrm{H}), 2.46-2.40(\mathrm{~m}, 2 \mathrm{H}), 2.34-2.26(\mathrm{~m}, 2 \mathrm{H}), 1.83(\mathrm{~s}, 3 \mathrm{H})$; minor isomer peaks: $8.04(\mathrm{br} \mathrm{s}), 2.05(\mathrm{~s}) ;{ }^{13} \mathrm{C} \mathrm{NMR}$ $\left(75 \mathrm{MHz}, \mathrm{CDCl}_{3}\right) \delta \mathrm{ppm} \mathrm{153.4,} \mathrm{151.6,} \mathrm{137.7,} \mathrm{136.9,} \mathrm{129.3,} \mathrm{125.3,} \mathrm{121.9,} \mathrm{115.0,} \mathrm{38.0,} \mathrm{30.5,} \mathrm{14.5;} \mathrm{visible}$ minor isomer peak: 22.7; IR (film): 3259, 2927, 1722, 1523, 1490, 1195, $1026 \mathrm{~cm}^{-1}$; HRMS (EI): Exact mass calcd for $\mathrm{C}_{13} \mathrm{H}_{16} \mathrm{~N}_{2} \mathrm{O}_{2}[\mathrm{M}]+:$ 232.1212. Found: 232.11896 .<smiles>O=C(N/N=C/c1ccc(C(F)(F)F)cc1)Oc1ccccc1</smiles>

Phenyl 2-(4-(trifluoromethyl)benzylidene)hydrazinecarboxylate (4i - substrate for Figure 23)

Synthesized according to general procedure 1 using phenyl carbazate $(0.608 \mathrm{~g}, 4.00 \mathrm{mmol})$, 4(trifluoromethyl)benzaldehyde $(0.546 \mathrm{~g}, 4.00 \mathrm{mmol})$, acetic acid $(0.046 \mathrm{~mL}, 0.80 \mathrm{mmol})$, methanol $(10$ $\mathrm{mL}$ ), room temperature, $16 \mathrm{~h}$. Solvent was evaporated and $15 \mathrm{~mL} \mathrm{CH} \mathrm{Cl}_{2}$ was added. The organic layer was washed with dilute aqueous $\mathrm{NaHCO}_{3}$ twice, dried with $\mathrm{Na}_{2} \mathrm{SO}_{4}$, and filtered. Evaporation of solvent gave the desired product $(1.21 \mathrm{~g}, 98 \%)$ as a white solid. $\mathrm{R}_{f} 0.4\left(100 \% \mathrm{CH}_{2} \mathrm{Cl}_{2}\right) ;{ }^{1} \mathrm{H} \mathrm{NMR}\left(300 \mathrm{MHz}, \mathrm{CDCl}_{3}\right)$ $\delta$ ppm 8.40 (br s, 1H), 8.08 (br s, 1H), $7.81(\mathrm{~d}, J=7.8 \mathrm{~Hz}, 2 \mathrm{H}), 7.63(\mathrm{~d}, J=8.4 \mathrm{~Hz}, 2 \mathrm{H}), 7.39(\mathrm{t}, J=7.8 \mathrm{~Hz}$, $2 \mathrm{H}), 7.22(\mathrm{t}, J=8.4 \mathrm{~Hz}, 3 \mathrm{H}) ;{ }^{13} \mathrm{C} \mathrm{NMR}\left(75 \mathrm{MHz}, \mathrm{CDCl}_{3}\right) \delta \mathrm{ppm} 152.6,150.7,144.9,138.2,130.4,130.1$,

67. Mukai, C.; Nomura, I.; Katagaki, S. J. Org. Chem. 2003, 68, 1376 
127.9, 126.3, 126.1 (m), 125.8 (t, $J=272 \mathrm{~Hz}), 122.1$; IR (film): 3265, 1735, 1490, 1333, 1204, 1108, 926, 838, 794, 733, $681 \mathrm{~cm}^{-1}$; HRMS (EI): Exact mass calcd for $\mathrm{C}_{15} \mathrm{H}_{11} \mathrm{~N}_{2} \mathrm{O}_{2} \mathrm{~F}_{3}[\mathrm{M}]^{+}:$308.0773. Found: 308.0755 .<smiles>O=C(N/N=C/c1cccs1)Oc1ccccc1</smiles>

\section{Phenyl 2-(thiophen-2-ylmethylene)hydrazinecarboxylate $(4 \mathbf{j}$ - substrate for Figure 24$)$}

Synthesized according to literature ${ }^{65}$ with minor modifications. Phenyl carbazate $(0.304 \mathrm{~g}, 2.00 \mathrm{mmol})$, thiophene-2-carbaldehyde $(0.224 \mathrm{~g}, 2.00 \mathrm{mmol})$, acetic acid $(0.04 \mathrm{~mL})$ and methanol $(5 \mathrm{~mL})$ were combined and left to stir for $1 \mathrm{~h}$ at room temperature. After solvent was evaporated, hot methanol was added and an insoluble brown solid was filtered off. Recrystallization in methanol afforded the desired product $(0.343$ $\mathrm{g}, 70 \%)$ as a dark orange solid. Characterization data matches that reported in the literature. ${ }^{65}$<smiles>COc1ccc(/C(=N/NC(=O)OC(C)(C)C)C2CC2)cc1</smiles>

tert-Butyl 2-(cyclopropyl(4-methoxyphenyl)methylene)hydrazinecarboxylate $(4 \mathrm{k}$ - substrate for Figure 24)

Synthesized according to general procedure 1 using tert-butylcarbazate $(0.457 \mathrm{~g}, 3.00 \mathrm{mmol})$, cyclopropyl(4-methoxyphenyl)methanone $(0.352 \mathrm{~g}, 2.0 \mathrm{mmol})$, acetic acid $(0.04 \mathrm{~mL})$, methanol $(5 \mathrm{~mL})$. Purification by flash chromatography (30\% ethyl acetate/petroleum ether) afforded the desired product $(0.234 \mathrm{~g}, 40 \%)$, a white solid, as a mix of isomers in a 5:1 ratio. $\mathrm{R}_{f} 0.6$ (30\% ethyl acetate/petroleum ether); ${ }^{1} \mathrm{H}$ NMR $\left(300 \mathrm{MHz}, \mathrm{CDCl}_{3}\right) \delta \mathrm{ppm} 8.52$ (br s, $\left.1 \mathrm{H}\right), 7.76(\mathrm{~d}, J=8.9 \mathrm{~Hz}, 1 \mathrm{H}), 6.84(\mathrm{~d}, J=8.9 \mathrm{~Hz}, 1 \mathrm{H}), 3.80$ $(\mathrm{s}, 3 \mathrm{H}), 1.55(\mathrm{~s}, 9 \mathrm{H}), 1.15-1.09(\mathrm{~m}, 2 \mathrm{H}), 0.79-0.68(\mathrm{~m}, 1 \mathrm{H}), 0.65-0.60(\mathrm{~m}, 2 \mathrm{H})$; minor isomer peaks: *7.42 (br s, $1 \mathrm{H}), * 7.10(\mathrm{~d}, J=8.7 \mathrm{~Hz}, 1 \mathrm{H}), * 6.97(\mathrm{~d}, J=8.9 \mathrm{~Hz}, 1 \mathrm{H}), * 3.83(\mathrm{~s}, 3 \mathrm{H}), * 1.45(\mathrm{~s}, 9 \mathrm{H}) ;{ }^{13} \mathrm{C}$ NMR $(75$ $\left.\mathrm{MHz}, \mathrm{C}_{6} \mathrm{D}_{6}\right) \delta \mathrm{ppm} 160.9,130.7,129.3,128.7,128.4$ (overlaps with solvent peak), 114.1, 80.7, 55.1, 28.8, 7.5, 6.4; IR (film): 3224, 2991, 1719, 1607, 1502, 1361, 1232, 1136, 1063, $818 \mathrm{~cm}^{-1}$; HRMS (EI): Exact mass calcd for $\mathrm{C}_{16} \mathrm{H}_{22} \mathrm{~N}_{2} \mathrm{O}_{3}[\mathrm{M}]^{+}: 290.1630$. Found: 290.16346 .<smiles>C/C(CC/C(C)=N/NC(=O)OC(C)(C)C)=N\NC(=O)OC(C)(C)C</smiles>

tert-Butyl 2,2'-(hexane-2,5-diylidene)bis(hydrazinecarboxylate) (5a - Eq 14)

To a round bottom flask charged with magnetic stirrer was added hexan-2,5-dione $(0.35 \mathrm{~mL}, 3.0 \mathrm{mmol})$, tert-butylcarbazate $(1.22 \mathrm{~g}, 9.20 \mathrm{mmol})$, and methanol $(8 \mathrm{~mL})$. As acetic acid was added, a white solid crashed out of solution. The white solid was collected by filtration and washed with methanol. This afforded the desired product $(0.886 \mathrm{~g}, 87 \%)$ as a white solid. ${ }^{1} \mathrm{H}$ NMR $\left(300 \mathrm{MHz}, \mathrm{DMSO}-d_{6}\right) \delta \mathrm{ppm}$ (major isomer peaks) 7.38 (brs, 2H), $2.61(\mathrm{~s}, 4 \mathrm{H}), 1.84(\mathrm{~s}, 6 \mathrm{H}), 1.52(\mathrm{~s}, 18 \mathrm{H})$, (minor isomer peaks) 2.53, 2.01; ${ }^{13} \mathrm{C}$ NMR (75 MHz, DMSO- $d_{6}$ ) $\delta$ ppm (missing quaternary carbon), 151.3, 80.9, 35.2, 28.3, 15.2; IR (film): 
3390, 1721, 1680, 1536, 1487, 1174; HRMS (EI): Exact mass calcd for C16H30O4N4 [M]+: 342.2267. Found: 342. 2278.

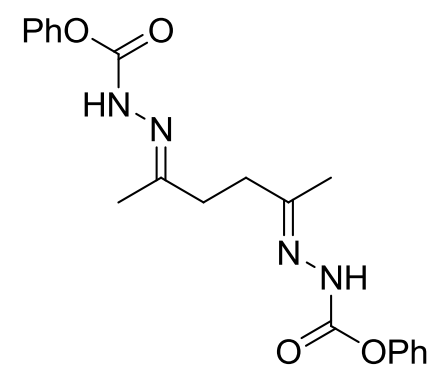

\section{Diphenyl 2,2'-(hexane-2,5-diylidene)bis(hydrazinecarboxylate) (5b - Eq 15)}

To a round bottom flask charged with magnetic stirrer was added hexan-2,5-dione $(0.176 \mathrm{~mL}, 1.50 \mathrm{mmol})$, phenyl carbazate $(0.569 \mathrm{~g}, 3.70 \mathrm{mmol})$, and methanol $(5 \mathrm{~mL})$. As acetic acid was added dropwise, a white solid crashed out of solution. The white solid was filtered and washed with methanol. This afforded the desired product $(0.292 \mathrm{~g}, 50 \%)$ as a white solid. ${ }^{1} \mathrm{H}$ NMR $\left(300 \mathrm{MHz}, \mathrm{DMSO}-d_{6}\right) \delta \mathrm{ppm} 10.27$ (br s, 2H), 7.40-7.35 (m, 4H), 7.23-7.18 (m, 2H), 7.15-7.12 (m, 4H), $2.43(\mathrm{~s}, 4 \mathrm{H}), 1.88(\mathrm{~s}, 6 \mathrm{H}) ;{ }^{13} \mathrm{C} \mathrm{NMR}(75 \mathrm{MHz}$, DMSO- $\left.d_{6}\right) \delta$ ppm 151.1, 129.8, 125.7, 122.3, 35.5, 16.9; IR (film) 3450, 1715, 1747, 1491, $1243 \mathrm{~cm}^{-1}$; HRMS (EI): Exact mass calcd for $\mathrm{C}_{20} \mathrm{H}_{22} \mathrm{~N}_{4} \mathrm{O}_{4}[\mathrm{M}]^{+}: 382.1641$. Found: 382.16523 


\section{Preparation of Hydrazone Derivatives Using Leaving Group Exchange}

\section{General procedure 2}

To a flame-dried round bottom flask charged with a magnetic stirrer were added hydrazone (1 equiv.), dry $\mathrm{PhCF}_{3}$, followed by the nucleophile (2- 5 equiv). The flask was sealed, purged with argon and left to stir for the time and temperature specified. Purification was performed by flash chromatography or recrystallization.

\section{General procedure 3}

To a flame-dried microwave vial charged with a magnetic stirrer were added hydrazone (1 equiv), dry $\mathrm{PhCF}_{3}$, followed by the nucleophile (2-5 equiv.). The vial was sealed with a microwave cap, purged with argon and irradiated for the time and temperature specified. Purification was performed by flash chromatography or recrystallization.<smiles>CCCCCCNC(=O)NN=C(C(C)C)C(C)C</smiles>

\section{2-(2,4-Dimethylpentan-3-ylidene)- $N$-hexylhydrazinecarboxamide (1b)}

Synthesized according to general procedure $\mathbf{2}$ using tert-butyl 2-(2,4-dimethylpentan-3ylidene)hydrazinecarboxylate $(0.248 \mathrm{~g}, 1.00 \mathrm{mmol}), n$-hexylamine $(0.38 \mathrm{~mL}, 2.0 \mathrm{mmol}), \mathrm{PhCF}_{3}(5.0 \mathrm{~mL})$, $120{ }^{\circ} \mathrm{C}, 20 \mathrm{~min}$. Purification by flash chromatography (10\% ethyl acetate/dichloromethane) afforded the desired product $\left(0.202 \mathrm{~g}, 79 \%\right.$ yield) as a yellow oil. $\mathrm{R}_{f} 0.59$ (3\% methanol/dichloromethane); ${ }^{1} \mathrm{H}$ NMR $\left(300 \mathrm{MHz}, \mathrm{CDCl}_{3}\right) \delta \mathrm{ppm} 8.35(\mathrm{~s}, 1 \mathrm{H}), 6.14(\mathrm{~s}, 1 \mathrm{H}), 3.21(\mathrm{q}, J=7.0 \mathrm{~Hz}, 2 \mathrm{H}), 2.84(\mathrm{sept}, J=7.0 \mathrm{~Hz}, 1 \mathrm{H})$, 2.52 (sept, $J=6.7 \mathrm{~Hz}, 1 \mathrm{H}$ ), 1.47 (quin, $J=7.0,6.8,7.2,7.4 \mathrm{~Hz}, 2 \mathrm{H}$ ), $1.24(\mathrm{~m}, 6 \mathrm{H}), 1.03$ (dd, $J=7.6,7.0$ $\mathrm{Hz}, 12 \mathrm{H}), 0.81(\mathrm{t}, J=6.6,6.7 \mathrm{~Hz}, 3 \mathrm{H}) ;{ }^{13} \mathrm{C} \mathrm{NMR}\left(75 \mathrm{MHz}, \mathrm{CDCl}_{3}\right) \delta \mathrm{ppm} 160.2,157.0,39.5,31.5,30.1$, 30.1, 27.9, 26.5, 22.5, 21.9, 18.8, 13.9; IR (film); 3420, 3207, 2960, 2929, 2857, 1679, 1538, $1066 \mathrm{~cm}^{-1}$; HRMS (EI): Exact mass calcd for $\mathrm{C}_{14} \mathrm{H}_{29} \mathrm{~N}_{3} \mathrm{O}$ [M]+: 255.3996. Found: 255.2319.<smiles>CC(C)C(=NNC(=O)Nc1ccccc1)C(C)C</smiles>

\section{2-(2,4-Dimethylpentan-3-ylidene)- $N$-phenylhydrazinecarboxamide (1c)}

Synthesized according to general procedure $\mathbf{3}$ with tert-butyl 2-(2,4-dimethylpentan-3ylidene)hydrazinecarboxylate $(0.228 \mathrm{~g}, 1.00 \mathrm{mmol})$, aniline $(0.186 \mathrm{~mL}, 2.00 \mathrm{mmol}), \mathrm{PhCF}_{3}(2 \mathrm{~mL}), 120$ ${ }^{\circ} \mathrm{C}, 20$ min. Purification by flash chromatography (12\% ethyl acetate/hexanes) afforded the desired product $(0.193 \mathrm{~g}, 78 \%)$ as a yellow oil. $\mathrm{R}_{f} 0.65$ (30\% ethyl acetate/hexanes); ${ }^{1} \mathrm{H}$ NMR $\left(300 \mathrm{MHz}, \mathrm{CDCl}_{3}\right) \delta \mathrm{ppm}$ $8.73(\mathrm{~s}, 1 \mathrm{H}), 8.30(\mathrm{~s}, 1 \mathrm{H}), 7.52(\mathrm{~d}, J=1.2 \mathrm{~Hz}, 1 \mathrm{H}), 7.49(\mathrm{~d}, J=0.9 \mathrm{~Hz}, 1 \mathrm{H}), 7.29(\mathrm{~m}, 2 \mathrm{H}), 7.03(\mathrm{~m}, 1 \mathrm{H})$, 2.99 (sept, $J=6.9 \mathrm{~Hz}, 1 \mathrm{H}), 2.65$ (sept, $J=6.7 \mathrm{~Hz}, 1 \mathrm{H}), 1.14(\mathrm{dd}, J=6.9,1.6 \mathrm{~Hz}, 12 \mathrm{H}) ;{ }^{13} \mathrm{C} \mathrm{NMR}(75 \mathrm{MHz}$, $\left.\mathrm{CDCl}_{3}\right) \delta \mathrm{ppm} 161.1(\mathrm{C}), 154.3(\mathrm{C}), 138.4(\mathrm{C}), 128.2(2 \mathrm{CH}), 122.9(\mathrm{CH}), 119.2(\mathrm{CH}), 30.3(\mathrm{CH}), 28.3$ 
(CH), $22.0\left(2 \mathrm{CH}_{3}\right), 18.9\left(2 \mathrm{CH}_{3}\right)$; IR (film); 2967, 2933, 2872, 1683, 1590, 1538, 1443, $1033 \mathrm{~cm}^{-1}$; HRMS (EI): Exact mass calcd for $\mathrm{C}_{14} \mathrm{H}_{21} \mathrm{~N}_{3} \mathrm{O}[\mathrm{M}]+:$ 247.1685. Found: 247.1679.<smiles>CC(C)C(=NNC(=O)N1CCOCC1)C(C)C</smiles>

\section{$N^{\prime}$-(2,4-Dimethylpentan-3-ylidene)morpholine-4-carbohydrazide (1d)}

Synthesized according to general procedure $\mathbf{3}$ using tert-butyl 2-(2,4-dimethylpentan-3ylidene)hydrazinecarboxylate $(0.228 \mathrm{~g}, 1.00 \mathrm{mmol})$, morpholine $(0.172 \mathrm{~mL}, 2.00 \mathrm{mmol}), \mathrm{PhCF}_{3}(5.0 \mathrm{~mL})$, $120{ }^{\circ} \mathrm{C}, 20 \mathrm{~min}$. Purification by column chromatography ( $2 \%$ methanol/dichloromethane) afforded the desired product $(0.218 \mathrm{~g}, 91 \%)$ as a white solid. $\mathrm{R}_{f} 0.41$ (3\% methanol/dichloromethane); ${ }^{1} \mathrm{H}$ NMR (400 $\left.\mathrm{MHz}, \mathrm{CDCl}_{3}\right) \delta=7.66(\mathrm{~s}, 1 \mathrm{H}), 3.61(\mathrm{t}, J=4.3,5.0 \mathrm{~Hz}, 4 \mathrm{H}), 3.51(\mathrm{t}, J=5.0,4.3 \mathrm{~Hz}, 4 \mathrm{H}), 2.80(\mathrm{sept}, J=$ $13.8,6.9 \mathrm{~Hz}, 1 \mathrm{H}), 2.51(\mathrm{sept}, J=13.4,6.7 \mathrm{~Hz}, 1 \mathrm{H}), 1.02(\mathrm{~d}, J=7.0 \mathrm{~Hz}, 6 \mathrm{H}), 0.97(\mathrm{~d}, J=6.8 \mathrm{~Hz}, 6 \mathrm{H}) ;{ }^{13} \mathrm{C}$ NMR (75 MHz, $\left.\mathrm{CDCl}_{3}\right) \delta 162.2,158.3,68.8,46.1,30.5,27.3,21.9,18.7$; IR (film) 1645, 1534, 1250, 1109 , $1044 \mathrm{~cm}^{-1}$; LRMS m/z (relative intensity): 198.1226 (100\%), 70.0291 (35.3\%).<smiles>CC(C)C(=NNC(=O)NC(C)(C)C)C(C)C</smiles>

\section{N-tert-Butyl-2-(2,4-dimethylpentan-3-ylidene)hydrazinecarboxamide (1e)}

Synthesized according to general procedure $\mathbf{3}$ using tert-butyl 2-(2,4-dimethylpentan-3ylidene)hydrazinecarboxylate $(0.228 \mathrm{~g}, 1.00 \mathrm{mmol})$, tert-butylamine $(0.236 \mathrm{~mL}, 2.00 \mathrm{mmol}), \mathrm{PhCF}_{3}(5$ $\mathrm{mL}), 120{ }^{\circ} \mathrm{C}$ for $20 \mathrm{~min}$. Purification by flash chromatography ( $1 \%$ methanol/ dichloromethane) afforded the desired product $(0.190 \mathrm{~g}, 83 \%)$ as a white solid. $\mathrm{R}_{f} 0.57$ (3\% methanol/ dichloromethane); ${ }^{1} \mathrm{H}$ NMR $\left(\mathrm{CDCl}_{3}, 300 \mathrm{MHz}\right) \delta \mathrm{ppm} 8.88(\mathrm{~s}, 1 \mathrm{H}), 6.16(\mathrm{~s}, 1 \mathrm{H}), 3.00$ (sept, $\left.J=6.9 \mathrm{~Hz}, 1 \mathrm{H}\right), 2.53$ (sept, $J=6.7 \mathrm{~Hz}$, $1 \mathrm{H}), 1.33(\mathrm{~s}, 9 \mathrm{H}), 1.04(\mathrm{t}, J=6.9 \mathrm{~Hz}, 9 \mathrm{H}) ;{ }^{13} \mathrm{C} \mathrm{NMR}\left(\mathrm{CDCl}_{3}, 75 \mathrm{MHz}\right) \delta \mathrm{ppm} 159.3(\mathrm{C}), 155.8(\mathrm{C}), 49.8$ (C), $30.4(\mathrm{CH}), 29.3\left(3 \mathrm{CH}_{3}\right), 27.9(\mathrm{CH}), 21.8\left(2 \mathrm{CH}_{3}\right), 18.8\left(2 \mathrm{CH}_{3}\right)$; IR (film); 3397, 2963, 1679, 1531, 1143 $\mathrm{cm}^{-1}$; LRMS m/z (relative intensity): 85.0769 (100\%), 100.0990 (62.4\%), 184.1438 (61.8\%), 128.1308 (42.7\%), 128.0819 (24.4\%), 113.1097 (23.5\%).<smiles>CC(C)C(=NNC(=O)Sc1ccccc1)C(C)C</smiles>

\section{S-Phenyl 2-(2,4-dimethylpentan-3-ylidene)hydrazinecarbothioate (1f)}

Synthesized according to general procedure $\mathbf{3}$ using tert-butyl 2-(2,4-dimethylpentan-3ylidene)hydrazinecarboxylate $(0.228 \mathrm{~g}, 1.00 \mathrm{mmol})$, thiophenol $(0.236 \mathrm{~mL}, 2.00 \mathrm{mmol}), \mathrm{PhCF}_{3}(2 \mathrm{~mL})$, $120{ }^{\circ} \mathrm{C}$ for $2 \mathrm{~h}$. Purification by flash chromatography ( $10 \%$ hexanes/dichloromethane) afforded the desired product $(0.224 \mathrm{~g}, 75 \%)$ as a white solid. $\mathrm{R}_{f} 0.3\left(10 \%\right.$ hexanes/dichloromethane); m.p.: $170-172{ }^{\circ} \mathrm{C} ;{ }^{1} \mathrm{H}$ NMR (400 MHz, $\left.\mathrm{CDCl}_{3}\right) \delta 9.90(\mathrm{~s}, 1 \mathrm{H}), 7.56-7.47(\mathrm{~m}, 2 \mathrm{H}), 7.39-7.32(\mathrm{~m}, 3 \mathrm{H}), 2.72$ (sept., $J=6.86 \mathrm{~Hz}$, $1 \mathrm{H}), 2.60$ (sept, $J=6.74 \mathrm{~Hz}, 1 \mathrm{H}), 1.14(\mathrm{~d}, J=6.75 \mathrm{~Hz}, 6 \mathrm{H}), 0.92(\mathrm{~d}, J=6.92 \mathrm{~Hz}, 6 \mathrm{H}) ;{ }^{13} \mathrm{C}$ NMR $(100$ $\left.\mathrm{MHz}, \mathrm{CDCl}_{3}\right) \delta 172.0,164.9,135.8,129.5,128.8,128.6,30.5,28.3,22.0,18.8$. IR (film) 2971, 2931, 2868, 1654, 1406, 1303, 1266, 1217, $1064 \mathrm{~cm}^{-1}$; HRMS (EI): Exact mass calcd for $\mathrm{C}_{14} \mathrm{H}_{20} \mathrm{~N}_{2} \mathrm{OS}[\mathrm{M}]^{+}: 264.1291$. Found: 264.1295. 
<smiles>CCCCCCCCSC(=O)NN=C(C(C)C)C(C)C</smiles>

\section{S-Octyl 2-(2,4-dimethylpentan-3-ylidene)hydrazinecarbothioate (1h)}

Synthesized according to general procedure $\mathbf{3}$ using tert-butyl 2-(2,4-dimethylpentan-3ylidene)hydrazinecarboxylate $(0.228 \mathrm{~g}, 1.00 \mathrm{mmol})$, octanethiol $(0.347 \mathrm{~mL}, 2.00 \mathrm{mmol}), \mathrm{PhCF}_{3}(2 \mathrm{~mL})$, $120^{\circ} \mathrm{C}, 3 \mathrm{~h}$. Purification by column chromatography (10\% hexanes/dichloromethane) afforded the desired product $(0.245 \mathrm{~g}, 82 \%)$ as a white solid. $\mathrm{R}_{f} 0.33$ (10\% hexanes/dichloromethane); ${ }^{1} \mathrm{H}$ NMR (300 MHz, $\left.\mathrm{CDCl}_{3}\right) \delta \mathrm{ppm} 9.51(\mathrm{~s}, 1 \mathrm{H}), 2.94-2.88(\mathrm{~m}, 1 \mathrm{H}), 2.83(\mathrm{t}, J=7.5 \mathrm{~Hz}, 2 \mathrm{H}), 2.63(\mathrm{sept}, \mathrm{J}=6.8 \mathrm{~Hz}, 1 \mathrm{H}), 1.67-$ $1.60(\mathrm{~m}, 2 \mathrm{H}), 1.43-1.36(\mathrm{~m}, 2 \mathrm{H}), 1.32-1.24(\mathrm{~m}, 8 \mathrm{H}), 1.15-1.12(\mathrm{~m}, 12 \mathrm{H}), 0.89-0.86(\mathrm{~m}, 3 \mathrm{H}) ;{ }^{13} \mathrm{C}$ NMR $(75$ $\left.\mathrm{MHz}, \mathrm{CDCl}_{3}\right) \delta \mathrm{ppm} 173.4,163.9,31.8,30.6,30.1,29.2,29.1,28.8,28.2,22.6,22.0,18.9,14.0$; IR (film) 3186, 3062, 2963, 2927, 2855, 1652, 1464, 1371, 1308, 1270, 1131, 1065, $1009 \mathrm{~cm}^{-1}$; HRMS (EI): Exact mass calcd for $\mathrm{C}_{16} \mathrm{H}_{32} \mathrm{~N}_{2} \mathrm{OS}$ [M]+: 300.2235. Found: 300.2238 .<smiles>CC(C)NC(=O)NN=C(C(C)C)C(C)C</smiles>

\section{2-(2,4-Dimethylpentan-3-ylidene)- $N$-isopropylhydrazinecarboxamide (1i)}

Synthesized according to general procedure $\mathbf{3}$ using tert-butyl 2-(2,4-dimethylpentan-3ylidene hydrazinecarboxylate $(0.124 \mathrm{~g}, 0.500 \mathrm{mmol})$, isopropylamine $(0.082 \mathrm{~g}, 1.0 \mathrm{mmol}), \mathrm{PhCF}_{3}(2.5 \mathrm{~mL})$, $100{ }^{\circ} \mathrm{C}, 20 \mathrm{~min}$. Purification by flash chromatography (40\% ethyl acetate/hexanes) afforded the desired product $(0.088 \mathrm{~g}, 83 \%)$ as a white solid. $\mathrm{R}_{f} 0.15$ (40\% ethyl acetate/ hexanes); ${ }^{1} \mathrm{H} \mathrm{NMR}\left(300 \mathrm{MHz}, \mathrm{CDCl}_{3}\right)$ $\delta$ ppm 9.16 (br s, 1H), 6.23 (br s, 1H), 4.24-4.13 (m, 1H), 2.73 (sept, $J=6.9 \mathrm{~Hz}, 1 \mathrm{H}$ ), 2.31 (sept. $J=6.9$ $\mathrm{Hz}, 1 \mathrm{H}), 1.05(\mathrm{dd}, J=14.0,6.6 \mathrm{~Hz}, 12 \mathrm{H}), 0.82(\mathrm{~d}, J=6.9 \mathrm{~Hz}, 6 \mathrm{H}) ;{ }^{13} \mathrm{C} \mathrm{NMR}\left(100 \mathrm{MHz}, \mathrm{C}_{6} \mathrm{D}_{6}\right) \delta 159.9(\mathrm{C})$, $157.4(\mathrm{C}), 42.4(\mathrm{CH}), 30.8(\mathrm{CH}), 28.5(\mathrm{CH}), 23.9\left(2 \mathrm{CH}_{3}\right), 22.9\left(2 \mathrm{CH}_{3}\right), 19.4\left(2 \mathrm{CH}_{3}\right)$; IR (film) 3405, 3188, 3084, 2966, 2872, 1668, 1526, 1466, 1365, 1325, $761 \mathrm{~cm}^{-1}$; HRMS (EI): Exact mass calcd for $\mathrm{C}_{11} \mathrm{H}_{23} \mathrm{~N}_{3} \mathrm{O}$ $[\mathrm{M}]^{+}:$213.1841. Found 213.1831.<smiles>CC(C)C(=NNC(=O)N(C(C)C)C(C)C)C(C)C</smiles>

\section{2-(2,4-Dimethylpentan-3-ylidene)- $N, N$-diisopropylhydrazinecarboxamide (1j)}

tert-Butyl 2-(2,4-dimethylpentan-3-ylidene)hydrazinecarboxylate $\quad\left(\begin{array}{llll}1.142 & \mathrm{~g}, & 5.00 \mathrm{mmol}) & \text { and }\end{array}\right.$ diisopropylamine $(10 \mathrm{~mL}, 70 \mathrm{mmol})$ were combined in a $10-20 \mathrm{~mL}$ flame dried microwave vial charged with a magnetic stir bar. The vial was heated for $3 \mathrm{~min}$ at $150{ }^{\circ} \mathrm{C}$. After evaporation of the diisopropylamine, recrystallization in hexanes afforded the desired product $(0.808 \mathrm{~g}, 63 \%)$ as a white solid. $\mathrm{R}_{f} 0.49$ (20\% ethyl acetate/hexanes); ${ }^{1} \mathrm{H}$ NMR (300 MHz, $\left.\mathrm{CDCl}_{3}\right) \delta \mathrm{ppm} 7.12$ (s, 1H), 3.88 (sept, $J=6.7$ $\mathrm{Hz}, 2 \mathrm{H}), 2.73$ (sept, $J=6.2 \mathrm{~Hz}, 1 \mathrm{H}), 2.57$ (sept, $J=6.8 \mathrm{~Hz}, 1 \mathrm{H}), 1.25(\mathrm{~d}, J=6.8 \mathrm{~Hz}, 12 \mathrm{H}), 1.10$ (d, $J=7.1$ $\mathrm{Hz}, 6 \mathrm{H}), 1.06(\mathrm{~d}, J=6.8 \mathrm{~Hz}, 6 \mathrm{H})$. Spectral data matched those reported in the literature. ${ }^{63}$ 
<smiles>CC(C)C(=NNC(=O)OCc1ccccc1)C(C)C</smiles>

\section{Benzyl 2-(2,4-dimethylpentan-3-ylidene)hydrazinecarboxylate (1k)}

Synthesized according to general procedure $\mathbf{3}$ using tert-butyl 2-(2,4-dimethylpentan-3ylidene)hydrazinecarboxylate $(0.228 \mathrm{~g}, 1.00 \mathrm{mmol})$, benzyl alcohol $(0.54 \mathrm{~mL}, 5.0 \mathrm{mmol}), \mathrm{PhCF}_{3}(2 \mathrm{~mL})$, $150{ }^{\circ} \mathrm{C}, 3 \mathrm{~min}$. Purification by chromatography (10\% ethyl acetate/toluene) afforded the desired product $(0.230 \mathrm{~g}, 85 \%)$ as a white solid. $\mathrm{R}_{f} 0.48$ (10\% ethyl acetate/toluene); ${ }^{1} \mathrm{H}$ NMR $\left(300 \mathrm{MHz}, \mathrm{CDCl}_{3}\right) \delta \mathrm{ppm}$ $7.80(\mathrm{~s}, 1 \mathrm{H}), 7.43-7.35(\mathrm{~m}, 5 \mathrm{H}), 5.23(\mathrm{~s}, 2 \mathrm{H}), 2.81-2.71(\mathrm{~m}, 1 \mathrm{H}), 2.70-2.61(\mathrm{~m}, 1 \mathrm{H}), 1.15(\mathrm{~d}, 12 \mathrm{H}) ;{ }^{13} \mathrm{C}$ NMR $\left(75 \mathrm{MHz}, \mathrm{CD}_{3} \mathrm{OD}\right) \delta \mathrm{ppm} 169.0,157.1,138.1,129.6,129.3,128.4,67.967,30.9,29.4,22.8,19.4$; IR (film) 3208, 3043, 2959, 1703, 1538, 1252, $1039 \mathrm{~cm}^{-1}$; HRMS (EI): Exact mass calcd for $\mathrm{C}_{15} \mathrm{H}_{22} \mathrm{~N}_{2} \mathrm{O}_{2}[\mathrm{M}]+$ : 262.1676. Found: 262.1687.<smiles>CC(C)C(=NNC(=O)OC(C)(C)C)C(C)C</smiles>

tert-Butyl 2-(2,4-dimethylpentan-3-ylidene)hydrazinecarboxylate (1a)

Synthesized according to general procedure 3 using benzyl 2-(2,4-dimethylpentan-3ylidene)hydrazinecarboxylate $(0.262 \mathrm{~g}, 1.00 \mathrm{mmol})$, tert-butanol $(0.48 \mathrm{~mL}, 5.0 \mathrm{mmol}), \mathrm{PhCF}_{3}(2.0 \mathrm{~mL})$, $150{ }^{\circ} \mathrm{C}, 3 \mathrm{~min}$. Purification by flash chromatography (10\% ethyl acetate/toluene) afforded the desired product $(0.182 \mathrm{~g}, 80 \%)$ as a white solid. ${ }^{1} \mathrm{H}$ NMR $\left(400 \mathrm{MHz}, \mathrm{CDCl}_{3}\right) \delta 7.60$ (br. s., $\left.1 \mathrm{H}\right), 2.73$ (sept, $J=$ $7.04 \mathrm{~Hz}, 1 \mathrm{H}), 2.59$ (sept, $J=6.81 \mathrm{~Hz}, 1 \mathrm{H}), 1.47(\mathrm{~s}, 9 \mathrm{H}), 1.12(\mathrm{~d}, J=7.03 \mathrm{~Hz}, 6 \mathrm{H}), 1.10(\mathrm{~d}, J=6.08 \mathrm{~Hz}$, $6 \mathrm{H}) .{ }^{13} \mathrm{C}$ NMR $\left(\mathrm{CDCl}_{3}, 100 \mathrm{MHz}\right) \delta 163.4(\mathrm{C}), 153.0(\mathrm{C}), 80.7(\mathrm{C}), 31.6(\mathrm{CH}), 28.4\left(\mathrm{CH}_{3}\right), 27.8$

$(\mathrm{CH}), 21.5\left(\mathrm{CH}_{3}\right), 19.0\left(\mathrm{CH}_{3}\right)$. Spectral data was found to be in agreement with literature data. ${ }^{63}$<smiles>CC(C)C(=NNC(=O)Oc1ccccc1)C(C)C</smiles>

\section{Phenyl 2-(2,4-dimethylpentan-3-ylidene)hydrazinecarboxylate (11)}

Synthesized according to general procedure $\mathbf{2}$ using tert-butyl 2-(2,4-dimethylpentan-3ylidene)hydrazinecarboxylate $(0.228 \mathrm{~g}, 1.00 \mathrm{mmol})$, phenol $(0.940 \mathrm{~g}, 10.0 \mathrm{mmol})$, PhCF3 $(2.0 \mathrm{~mL}), 150$ ${ }^{\circ} \mathrm{C}, 3 \mathrm{~min}$. Purification by flash chromatography (20\% ethyl acetate/hexanes) afforded the desired product $(0.065 \mathrm{~g}, 27 \%)$ as a white solid. $\mathrm{R}_{f} 0.45$ (20\% ethyl acetate/hexanes); ${ }^{1} \mathrm{H}$ NMR $(400 \mathrm{MHz}, \mathrm{CDCl} 3) \delta 8.08$ (br. s., $1 \mathrm{H}$ ), 7.38-7.31 (m, 2H), 7.22-7.15 (m, 3H), 2.82 (sept., $J=7.02 \mathrm{~Hz}, 1 \mathrm{H}$ ), 2.65 (sept., $J=6.75 \mathrm{~Hz}$, 1H), 1.19-1.12 (m, 9H). 13C NMR (75 MHz, CDCl3) $\delta 166.2(\mathrm{C}), 156.3(\mathrm{C}), 150.8(\mathrm{C}), 129.3(\mathrm{CH}), 125.5$ $(\mathrm{CH}), 121.5(\mathrm{CH}), 31.6(\mathrm{CH}), 27.9(\mathrm{CH}), 21.5(\mathrm{CH} 3), 18.9(\mathrm{CH} 3)$; IR 3214, 3028, 2963, 2930, 2872, 1723 , 1529, 1492, 1246, 1038, 1000, 737, 704, $683 \mathrm{~cm}^{-1}$; HRMS(EI): Exact mass calcd for $\mathrm{C}_{14} \mathrm{H}_{20} \mathrm{~N}_{2} \mathrm{O}_{2}$ [M]+: 248.1519. Found: 248.1495 
<smiles>CCCCOC(=O)NN=C(C(C)C)C(C)C</smiles>

\section{Butyl-2-(2,4-dimethylpentan-3-ylidene)hydrazinecarboxylate (1m)}

Synthesized according to general procedure 2 using 2-(2,4-dimethylpentan-3-ylidene)- $N, N$ diisopropylhydrazinecarboxamide $(0.064 \mathrm{~g}, 0.25 \mathrm{mmol}), n$-butanol $(0.23 \mathrm{~mL}, 2.5 \mathrm{mmol})$, and $\mathrm{PhCF}_{3}(0.5$ $\mathrm{mL}), 80^{\circ} \mathrm{C}, 16 \mathrm{~h}$. Evaporation of solvent under reduced pressure afforded the desired product $(0.054 \mathrm{~g}, 95$ $\%$ ) as a white solid. $\mathrm{R}_{f} 0.63$ (30\% ethyl acetate/ petroleum ether); ${ }^{1} \mathrm{H}$ NMR $\left(300 \mathrm{MHz}, \mathrm{CDCl}_{3}\right) \delta \mathrm{ppm} 7.77$ (br s, $1 \mathrm{H}$ ), $4.16(\mathrm{t}, J=6.6 \mathrm{~Hz}, 2 \mathrm{H}$ ), 2.77 (quin, $J=6.9 \mathrm{~Hz}, 1 \mathrm{H}$ ), 2.62 (quin, $J=6.9 \mathrm{~Hz}, 1 \mathrm{H}$ ), 1.64 (quin, $J=$ $6.9 \mathrm{~Hz}, 2 \mathrm{H}), 1.38(\mathrm{q}, J=7.5 \mathrm{~Hz}, 2 \mathrm{H}), 1.16-1.10(\mathrm{~m}, 12 \mathrm{H}), 0.92(\mathrm{t}, J=7.5 \mathrm{~Hz}, 3 \mathrm{H}) ;{ }^{13} \mathrm{C}$ NMR $(75 \mathrm{MHz}$, $\left.\mathrm{CDCl}_{3}\right) \delta \mathrm{ppm} 164.1,154.3,65.4,31.6,30.9,28.3,27.6,21.4,19.0,18.8,13.7$; IR (film): 3215, 2958, 1736, 1699, 1539, 1247, 1226, $1045 \mathrm{~cm}^{-1}$; HRMS (EI): Exact mass calcd for $\mathrm{C}_{12} \mathrm{H}_{24} \mathrm{~N}_{2} \mathrm{O}_{2}[\mathrm{M}]+:$ 228.1838. Found: 228.1832.<smiles>CC(C)C(=NNC(=O)OCCCOC(=O)NN=C(C(C)C)C(C)C)C(C)C</smiles>

Propane-1,3-diyl bis(2-(2,4-dimethylpentan-3-ylidene)hydrazinecarboxylate) (1n)

Synthesized according to general procedure $\mathbf{2}$ using 2-(2,4-dimethylpentan-3-ylidene)- $N, N$ diisopropylhydrazinecarboxamide $(1.50 \mathrm{mmol}, 0.383 \mathrm{~g}), 1,3$-propandiol $(0.50 \mathrm{mmol}, 0.038 \mathrm{~g}), \mathrm{MeCN}(1$ $\mathrm{mL}), 80{ }^{\circ} \mathrm{C}, 6 \mathrm{~h}$. Purification by flash chromatography (60\% ethyl acetate/petroleum ether) afforded the desired product $(0.054 \mathrm{~g}, 28 \%)$ as a white solid. ${ }^{1} \mathrm{H}$ NMR $\left(300 \mathrm{MHz}, \mathrm{CDCl}_{3}\right) \delta \mathrm{ppm} 7.66$ (brs, $\left.2 \mathrm{H}\right), 4.26$ $(\mathrm{t}, J=6.3 \mathrm{~Hz}, 4 \mathrm{H}), 2.28(\mathrm{ddd}, J=6.9,6.7,6.7 \mathrm{~Hz}, 2 \mathrm{H}), 2.10-2.01(\mathrm{~m}, 2 \mathrm{H}), 1.87-1.79(\mathrm{~m}, 2 \mathrm{H}), 1.11(\mathrm{~d}, J=$

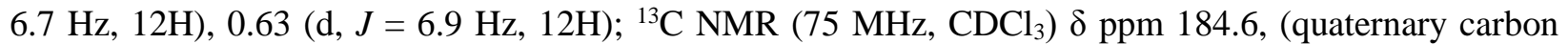
missing), 61.6, 30.3, 29.8, 28.7, 27.8, 26.9, 21.8, 18.2; IR (film): 2972, 2966, 1699, 1514, 1471, 1228, 1151, $734 \mathrm{~cm}^{-1}$; HRMS (EI): Exact mass calcd for $\mathrm{C}_{19} \mathrm{H}_{36} \mathrm{~N}_{4} \mathrm{O}_{4}[\mathrm{M}]+:$ 384.2737. Found: 384.2708.<smiles>C=CCCC/C=N/NC(=O)NC(C)C</smiles>

\section{2-(Hex-5-enylidene)- $N$-isopropylhydrazinecarboxamide (3a)}

Synthesized according to general procedure 3 using tert-butyl 2-(hex-5-enylidene)hydrazinecarboxylate $(0.212 \mathrm{~g}, 1.00 \mathrm{mmol})$, isopropylamine $(0.090 \mathrm{~mL}, 1.1 \mathrm{mmol}), \mathrm{PhCF}_{3}(2 \mathrm{~mL}), 150{ }^{\circ} \mathrm{C}, 30 \mathrm{~min}$. Purification by flash chromatography (40\% ethyl acetate/hexanes) afforded the desired product $(0.13 \mathrm{~g}, 66 \%)$ as a white solid. $\mathrm{R}_{f} 0.15$ (40\% ethyl acetate/hexanes); ${ }^{1} \mathrm{H} \mathrm{NMR}\left(300 \mathrm{MHz}, \mathrm{CDCl}_{3}\right) \delta \mathrm{ppm} 9.64$ (br s, $\left.1 \mathrm{H}\right), 7.11$ $(\mathrm{t}, J=3.9,1 \mathrm{H}), 5.83-5.75(\mathrm{~m}, 1 \mathrm{H}), 5.03-4.95(\mathrm{~m}, 2 \mathrm{H}), 4.03-3.96(\mathrm{~m}, 1 \mathrm{H}), 2.25-2.20(\mathrm{~m}, 2 \mathrm{H}), 2.11-2.05(\mathrm{~m}$, $2 \mathrm{H}), 1.63-1.55(\mathrm{~m}, 2 \mathrm{H}), 1.18(\mathrm{~d}, J=4.8 \mathrm{~Hz}, 6 \mathrm{H}) ;{ }^{13} \mathrm{C} \mathrm{NMR}\left(75 \mathrm{MHz}, \mathrm{CDCl}_{3}\right) \delta \mathrm{ppm} 156.3,144.2,138.1$, 115.1, 41.5, 33.2, 31.7, 25.8, 23.4; IR (film): 2927, 1674, 1535, 1280, 1122, 945, 759, $688 \mathrm{~cm}^{-1}$; HRMS (EI): Exact mass calcd for $\mathrm{C}_{10} \mathrm{H}_{19} \mathrm{~N}_{3} \mathrm{O}_{1}[\mathrm{M}]^{+}:$197.1528. Found: 197.1524. 
<smiles>C=CCCC/C=N/NC(=O)NC(C)(C)C</smiles>

$N$-tert-Butyl-2-(hex-5-enylidene)hydrazinecarboxamide (3b)

Synthesized according to general procedure 3 using tert-butyl 2-(hex-5-enylidene)hydrazinecarboxylate $(0.212 \mathrm{~g}, 1 \mathrm{mmol})$, tert-butylamine $(0.315 \mathrm{~mL}, 3 \mathrm{mmol}), \mathrm{PhCF}_{3}(2 \mathrm{~mL}), 150{ }^{\circ} \mathrm{C}$ for $30 \mathrm{~min}$. Purification by chromatography (30\% ethyl acetate/hexanes) afforded the desired product, white solid, $(0.161 \mathrm{~g}, 75 \%)$ as a mixture of E/Z isomers (7:3). $\mathrm{R}_{f} 0.14$ (30\% ethyl acetate/hexanes); ${ }^{1} \mathrm{H}$ NMR $\left(300 \mathrm{MHz}, \mathrm{CDCl}_{3}\right) \delta \mathrm{ppm}$ $8.33(\mathrm{~s}, 1 \mathrm{H}), 7.01(\mathrm{t}, J=5.4 \mathrm{~Hz}, 1 \mathrm{H}), 5.91(\mathrm{br} \mathrm{s}, 1 \mathrm{H}), 5.85-5.76(\mathrm{~m}, 1 \mathrm{H}), 5.07-4.98(\mathrm{~m}, 2 \mathrm{H}), 2.27-2.19(\mathrm{~m}$, $2 \mathrm{H}), 2.17-2.05(\mathrm{~m}, 2 \mathrm{H}), 1.70-1.56(\mathrm{~m}, 2 \mathrm{H}), 1.39(\mathrm{~s}, 9 \mathrm{H})$; Minor isomer peaks *8.14 $(\mathrm{s}, 1 \mathrm{H}), * 6.38(\mathrm{t}, J=$ $5.4 \mathrm{H}, 3 \mathrm{H}), * 6.09(\mathrm{br} \mathrm{s}, 1 \mathrm{H}) ;{ }^{13} \mathrm{C} \mathrm{NMR}\left(75 \mathrm{MHz}, \mathrm{CDCl}_{3}\right) \delta \mathrm{ppm} 155.9(\mathrm{C}), 143.4(\mathrm{CH}), 138.0(\mathrm{CH}), 115.0$ $\left(\mathrm{CH}_{2}\right), 50.11(\mathrm{C}), 33.1\left(\mathrm{CH}_{2}\right), 31.6\left(\mathrm{CH}_{2}\right), 29.3\left(\mathrm{CH}_{3}\right), 25.8\left(\mathrm{CH}_{2}\right)$, Minor isomer peaks *156.0 $(\mathrm{C})$, *143.2 $(\mathrm{CH}), * 137.7(\mathrm{CH}), * 115.3\left(\mathrm{CH}_{2}\right), * 50.14(\mathrm{C}), * 33.2\left(\mathrm{CH}_{2}\right), * 29.27\left(\mathrm{CH}_{3}\right), * 26.4\left(\mathrm{CH}_{2}\right), * 25.5\left(\mathrm{CH}_{2}\right)$; IR (film): 2970, 2923, 1670, 1527, 1365, 1184, 1130, 910, $759 \mathrm{~cm}^{-1}$; HRMS (EI): Exact mass calcd for $\mathrm{C}_{11} \mathrm{H}_{21} \mathrm{~N}_{3} \mathrm{O}[\mathrm{M}]+:$ 211.1685. Found: 211.1683.<smiles>C=CCCC/C=N/NC(=O)Nc1ccccc1</smiles>

\section{2-(Hex-5-enylidene)- $N$-phenylhydrazinecarboxamide (3c)}

Synthesized according to general procedure 3 using tert-butyl 2-(hex-5-enylidene)hydrazinecarboxylate $(0.212 \mathrm{~g}, 1 \mathrm{mmol})$, aniline $(0.315 \mathrm{~mL}, 2.20 \mathrm{mmol}), \mathrm{PhCF}_{3}(2 \mathrm{~mL}), 150{ }^{\circ} \mathrm{C}, 30 \mathrm{~min}$. The precipitate was filtered and purification by chromatography (30\% ethyl acetate/hexanes) afforded the desired product $(0.334 \mathrm{~g}, 72 \%)$ as a white solid. $\mathrm{R}_{f} 0.5$ (30\% ethyl acetate/hexanes); ${ }^{1} \mathrm{H}$ NMR $\left(300 \mathrm{MHz}, \mathrm{CDCl}_{3}\right) \delta \mathrm{ppm}$ $9.16(\mathrm{~s}, 1 \mathrm{H}), 8.23(\mathrm{~s}, 1 \mathrm{H}), 7.52(\mathrm{~d}, 2 \mathrm{H}), 7.32-7.26(\mathrm{~m}, 2 \mathrm{H}), 7.06(\mathrm{t}, 1 \mathrm{H}), 6.52(\mathrm{t}, 1 \mathrm{H}), 5.83-5.77(\mathrm{~m}, 1 \mathrm{H})$, 5.06-4.99 (m, 2H), 2.35-2.30 (m, 2H), $2.15(\mathrm{q}, J=5.4 \mathrm{~Hz}, 2 \mathrm{H}), 1.72$ (quin, $J=5.7 \mathrm{~Hz}, 2 \mathrm{H}) ;{ }^{13} \mathrm{C}$ NMR $(75$ $\left.\mathrm{MHz}, \mathrm{CDCl}_{3}\right) \delta$ ppm $153.9(\mathrm{C}), 144.6(\mathrm{CH}), 138.1(\mathrm{C}), 137.4(\mathrm{CH}), 128.9(\mathrm{CH}), 123.1(\mathrm{CH}), 119.3(\mathrm{CH})$, 115.6 $\left(\mathrm{CH}_{2}\right), 33.2\left(\mathrm{CH}_{2}\right), 26.5\left(\mathrm{CH}_{2}\right), 25.3\left(\mathrm{CH}_{2}\right)$; IR (film): 2964, 1674, 1525, 1454, 1390, 1361, 1139, 908 , $759 \mathrm{~cm}^{-1}$; HRMS (EI): Exact mass calcd for $\mathrm{C}_{13} \mathrm{H}_{17} \mathrm{~N}_{3} \mathrm{O}_{1}[\mathrm{M}]^{+}:$231.1372. Found: 231.1363.<smiles>C=CCCC/C=N/NC(=O)Sc1ccccc1</smiles>

\section{$S$-Phenyl 2-(hex-5-enylidene)hydrazinecarbothioate (3d)}

Synthesized according to general procedure 3 using tert-butyl 2-(hex-5-enylidene)hydrazinecarboxylate $(0.212 \mathrm{~g}, 1.00 \mathrm{mmol})$, thiophenol $(0.51 \mathrm{~mL}, 5.0 \mathrm{mmol}), \mathrm{PhCF}_{3}(2 \mathrm{~mL}), 150{ }^{\circ} \mathrm{C}, 2 \mathrm{~h}$. Purification by flash chromatography (10\% ethyl acetate/dichloromethane) afforded the desired product $(0.191 \mathrm{~g}, 77 \%)$ a white solid, as a mixture of isomers. $\mathrm{R}_{f} 0.6$ (10\% ethyl acetate/dichloromethane); ${ }^{1} \mathrm{H}$ NMR $\left(300 \mathrm{MHz}, \mathrm{CDCl}_{3}\right) \delta$ ppm 9.11 (br s, 1H), 7.54-7.51 (m, 1H), 7.43-7.36 (m, 2H), 7.27-7.23 (m, 1H), 7.21-7.12 (m, 1H), 5.83$5.70(\mathrm{~m}, 1 \mathrm{H}), 5.06-4.94(\mathrm{~m}, 2 \mathrm{H}), 2.41-2.27(\mathrm{~m}, 2 \mathrm{H}), 2.15-2.06(\mathrm{~m}, 2 \mathrm{H}), 1.70-1.58(\mathrm{~m}, 2 \mathrm{H}) ;{ }^{13} \mathrm{C} \mathrm{NMR}(75$ $\left.\mathrm{MHz}, \mathrm{CDCl}_{3}\right) \delta \mathrm{ppm} 152.5,147.0,137.9,136.7,129.0,128.8,125.8,115.1,33.2,31.6,25.9$; minor isomer peaks: 146.0, 135.6, 127.5, 127.1, 115.9, 33.4, 32.1, 26.2; IR (film): 2927, 1706, 1365, 1247, 1155, 732, $688 \mathrm{~cm}^{-1}$; HRMS(EI): Exact mass calcd for $\mathrm{C}_{13} \mathrm{H}_{16} \mathrm{~N}_{2} \mathrm{OS}[\mathrm{M}]^{+}:$248.0983. Found: 248.0894. 


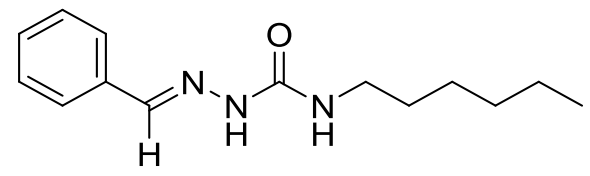

\section{2-Benzylidene- $N$-hexylhydrazinecarboxamide (3e)}

Synthesized according to general procedure $\mathbf{2}$ using tert-butyl 2-benzylidenehydrazinecarboxylate $(0.110$ g, $0.5 \mathrm{mmol}), n$-hexylamine $(0.19 \mathrm{~mL}, 1.0 \mathrm{mmol}), \mathrm{PhCF}_{3}(2.5 \mathrm{~mL}), 120{ }^{\circ} \mathrm{C}, 20 \mathrm{~min}$. Purification by recrystallization in methanol afforded the desired product $(0.078 \mathrm{~g}, 64 \%)$ as a white solid. $\mathrm{R}_{f} 0.19(30 \%$ ethyl acetate/petroleum ether); ${ }^{1} \mathrm{H}$ NMR $\left(300 \mathrm{MHz}, \mathrm{CDCl}_{3}\right) \delta \mathrm{ppm} 9.97(\mathrm{~s}, 1 \mathrm{H}), 7.80(\mathrm{~s}, 1 \mathrm{H}), 7.62-7.59(\mathrm{~m}$, $2 \mathrm{H}), 7.40-7.31(\mathrm{~m}, 3 \mathrm{H}), 6.19(\mathrm{t}, J=5.6 \mathrm{~Hz}, 1 \mathrm{H}), 3.35(\mathrm{dd}, J=6.9,6.2 \mathrm{~Hz}, 2 \mathrm{H}), 1.63-1.56(\mathrm{~m}, 2 \mathrm{H}), 1.40-$ $1.24(\mathrm{~m}, 6 \mathrm{H}), 0.88(\mathrm{t}, J=6.9 \mathrm{~Hz}, 3 \mathrm{H}) ;{ }^{13} \mathrm{C} \mathrm{NMR}\left(75 \mathrm{MHz}, \mathrm{CDCl}_{3}\right) \delta \mathrm{ppm} 156.8,141.0,134.3,129.5,128.6$, 126.7, 39.8, 31.5, 30.2, 26.6, 22.6, 14.0. IR (film): 2927, 1674, 1535, 1280, 1122, 945, 759, $688 \mathrm{~cm}^{-1}$; HRMS (EI): Exact mass calcd for $\mathrm{C}_{14} \mathrm{H}_{21} \mathrm{~N}_{3} \mathrm{O}$ [M]+: 247.1685. Found: 247.16941 .

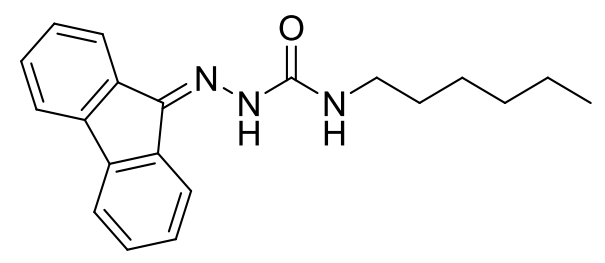

\section{2-(9H-Fluoren-9-ylidene)- $N$-hexylhydrazinecarboxamide (3f)}

Synthesized according to general procedure $\mathbf{2}$ using tert-butyl 2-(9H-fluoren-9-ylidene) hydrazinecarboxylate $(0.142 \mathrm{~g}, 0.500 \mathrm{mmol}), n$-hexylamine $(0.19 \mathrm{~mL}, 1.0 \mathrm{mmol}), \mathrm{PhCF}_{3}(2.5 \mathrm{~mL}), 120^{\circ} \mathrm{C}$, $20 \mathrm{~min}$. After solvent was evaporated under reduced pressure, methanol was added. The solid was collected by vacuum filtration to afford the desired product $(0.128 \mathrm{~g}, 79 \%)$ as a yellow solid. $\mathrm{R}_{f} 0.45$ (30\% ethyl acetate/petroleum ether); ${ }^{1} \mathrm{H}$ NMR $\left(300 \mathrm{MHz}, \mathrm{CDCl}_{3}\right) \delta \mathrm{ppm} 8.73$ (br s, $\left.1 \mathrm{H}\right), 7.90(\mathrm{~d}, 1 \mathrm{H}), 7.75(\mathrm{t}, 2 \mathrm{H})$, $7.64(\mathrm{~d}, 1 \mathrm{H}), 7.48(\mathrm{t}, 1 \mathrm{H}), 7.41-7.30(\mathrm{~m}, 3 \mathrm{H}), 6.54(\mathrm{br} \mathrm{s}, 1 \mathrm{H}), 3.43(\mathrm{q}, J=5.1 \mathrm{~Hz}, 2 \mathrm{H}), 1.66$ (quin, $J=5.4$ $\mathrm{Hz}, 2 \mathrm{H}), 1.45-1.34(\mathrm{~m}, 6 \mathrm{H}), 0.92(\mathrm{t}, J=5.4 \mathrm{~Hz}, 3 \mathrm{H}) ;{ }^{13} \mathrm{C}$ NMR $\left(75 \mathrm{MHz}, \mathrm{CDCl}_{3}\right) \delta \mathrm{ppm} 155.7,143.1$, 142.0, 139.2, 136.8, 130.9, 129.8, 129.6, 128.1, 128.0, 125.4, 121.2, 120.8, 119.8, 40.0, 31.5, 30.1, 26.6, 22.6, 14.0; IR (film): 3226, 2931, 1687, 1514, $1176 \mathrm{~cm}^{-1}$; HRMS (EI): Exact mass calcd for $\mathrm{C}_{20} \mathrm{H}_{23} \mathrm{~N}_{3} \mathrm{O}$ [M]+: 321.1836. Found: 321.1853 .

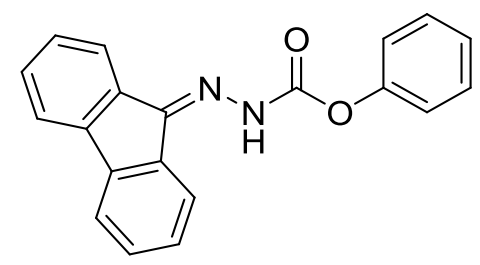

\section{Phenyl 2-(9H-fluoren-9-ylidene)hydrazinecarboxylate (3g)}

Synthesized according to general procedure $\mathbf{3}$ using tert-butyl 2-(9H-fluoren-9-ylidene) hydrazinecarboxylate $(0.147 \mathrm{~g}, 0.500 \mathrm{mmol})$, phenol $(0.471 \mathrm{~g}, 5.00 \mathrm{mmol}), \mathrm{PhCF}_{3}(2.5 \mathrm{~mL}), 150^{\circ} \mathrm{C}, 5 \mathrm{~min}$. Purification by flash chromatography (20\% ethyl acetate/petroleum ether) afforded to desired product $(0.024 \mathrm{~g}, 15 \%)$ as a yellow solid. $\mathrm{R}_{f} 0.31$ (20\% ethyl acetate/hexanes); ${ }^{1} \mathrm{H} \mathrm{NMR}\left(400 \mathrm{MHz}, \mathrm{CDCl}_{3}\right) \delta 9.18$ (s, 1H), $7.91(\mathrm{~d}, J=7.48 \mathrm{~Hz}, 1 \mathrm{H}), 7.82(\mathrm{~d}, J=7.63 \mathrm{~Hz}, 1 \mathrm{H}), 7.66(\mathrm{~d}, J=7.51 \mathrm{~Hz}, 1 \mathrm{H}), 7.56(\mathrm{~d}, J=7.43$ $\mathrm{Hz}, 1 \mathrm{H}), 7.47-7.21(\mathrm{~m}, 9 \mathrm{H}) .{ }^{13} \mathrm{C} \mathrm{NMR}\left(100 \mathrm{MHz}, \mathrm{CDCl}_{3}\right) \delta 152.1(\mathrm{C}), 150.6(\mathrm{C}), 142.6(\mathrm{C}), 139.5$ (C), $136.8(\mathrm{C}), 131.4(\mathrm{CH}), 130.3(\mathrm{CH}), 129.7(\mathrm{C}), 129.6(\mathrm{CH}), 128.4(\mathrm{CH}), 128.1(\mathrm{CH}), 126.0(\mathrm{CH}), 125.6$ $(\mathrm{CH}), 122.6(\mathrm{CH}), 121.5(\mathrm{CH}), 121.0(\mathrm{CH}), 119.7(\mathrm{CH})$. Spectral data matches those reported in the literature. ${ }^{63}$ 
<smiles>C=CCC/C(C)=N/NC(=O)NCCCCCC</smiles>

\section{2-(Hex-5-enylidene)- $N$-hexylhydrazinecarboxamide (4a)}

Synthesized according to general procedure 2 using phenyl 2-(hex-5-enylidene)hydrazinecarboxylate $(0.058 \mathrm{~g}, 0.50 \mathrm{mmol}), n$-hexylamine $(0.095 \mathrm{~mL}, 1.0 \mathrm{mmol}), \mathrm{PhCF}_{3}(1.25 \mathrm{~mL})$, room temperature, $30 \mathrm{~min}$. Purification by flash chromatography (30\% ethyl acetate/petroleum ether) afforded the desired product $(0.049 \mathrm{~g}, 83 \%)$, a clear, colorless oil, as a mixture of isomers (1:4). $\mathrm{R}_{f} 0.22$ (30\% ethyl acetate/petroleum ether); ${ }^{1} \mathrm{H}$ NMR $\left(300 \mathrm{MHz}, \mathrm{C}_{6} \mathrm{D}_{6}\right) \delta \mathrm{ppm} 10.07(\mathrm{~s}, 1 \mathrm{H}), 6.35(\mathrm{t}, J=5.9 \mathrm{~Hz}, 1 \mathrm{H}), 5.75-5.64(\mathrm{~m}, 1 \mathrm{H}), 5.01-$ $4.92(\mathrm{~m}, 2 \mathrm{H}), 3.31-3.22(\mathrm{~m}, 2 \mathrm{H}), 2.12-2.04(\mathrm{~m}, 4 \mathrm{H}), 1.72(\mathrm{~s}, 3 \mathrm{H}), 1.39-1.32(\mathrm{~m}, 2 \mathrm{H})$; minor isomer peaks: 10.4 (s), 5.98-5.84 (m), 2.45-2.38 (m), $1.71(\mathrm{~s}) ;{ }^{13} \mathrm{C}$ NMR (75 MHz, $\left.\mathrm{C}_{6} \mathrm{D}_{6}\right) \delta$ ppm 158.4, 149.1, 138.5, 115.3, 40.2, 38.6, 32.2, 31.1, 30.2, 27.3, 23.3, 16.2, 14.6; IR (film): 2939, 1681, 1539, 908, $729 \mathrm{~cm}^{-1}$; HRMS (EI): Exact mass calcd for $\mathrm{C}_{13} \mathrm{H}_{25} \mathrm{~N}_{3} \mathrm{O}$ [M]+: 239.1998. Found: 239.19957.<smiles>CCN(CC)C(=O)NN=C(C(C)C)C(C)C</smiles>

\section{2-(2,4-Dimethylpentan-3-ylidene)- $N, N$-diethylhydrazinecarboxamide (4b)}

Synthesized according to general procedure $\mathbf{2}$ using phenyl 2-(2,4-dimethylpentan-3-ylidene) hydrazinecarboxylate $(0.062 \mathrm{~g}, 0.25 \mathrm{mmol})$, diethylamine $(0.228 \mathrm{~mL}, 1.25 \mathrm{mmol}), \mathrm{PhCF}_{3}(1.25 \mathrm{~mL})$, room temperature, 20 min. Purification by flash chromatography (50\% ethyl acetate/petroleum ether) afforded the desired product $(0.033 \mathrm{~g}, 58 \%)$ as a white solid. $\mathrm{R}_{f} 0.45$ (50\% ethyl acetate/petroleum ether); ${ }^{1} \mathrm{H}$ NMR (300 MHz, $\left.\mathrm{C}_{6} \mathrm{D}_{6}\right) \delta \mathrm{ppm} 7.12$ (NH peak overlaps with solvent peak), 3.27 (q, $\left.J=6.9 \mathrm{~Hz}, 4 \mathrm{H}\right), 2.26(\mathrm{~m}, 2 \mathrm{H})$, $1.08-0.98(\mathrm{~m}, 12 \mathrm{H}), 0.65(\mathrm{~d}, J=6.9 \mathrm{~Hz}, 6 \mathrm{H}) ;{ }^{13} \mathrm{C} \mathrm{NMR}\left(75 \mathrm{MHz}, \mathrm{CDCl}_{3}\right) \delta \mathrm{ppm} 161.8,156.6,41.9,31.4$, 27.4, 21.6, 18.7, 13.8; IR (film) 3218, 3066, 2962, 2930, 2869, 1635, 1493, 1436, 1375, 1321, 1301, 1220, 1075, 1043, 794, $745 \mathrm{~cm}^{-1}$; HRMS (EI): Exact mass calcd for $\mathrm{C}_{12} \mathrm{H}_{25} \mathrm{~N}_{3} \mathrm{O}$ [M]+: 227.1992. Found: 227.1973.<smiles>O=C(NCCO)NN=C1c2ccccc2-c2ccccc21</smiles>

\section{2-(9H-Fluoren-9-ylidene)- $N$-(2-hydroxyethyl)hydrazinecarboxamide (4c)}

Synthesized according to general procedure 2 using 2 -(9H-fluoren-9-ylidene) hydrazinecarboxylate (0.079 $\mathrm{g}, 0.25 \mathrm{mmol})$, ethanolamine $(0.030 \mathrm{~mL}, 0.50 \mathrm{mmol}), \mathrm{PhCF}_{3}(1.25 \mathrm{~mL})$, room temperature, $1 \mathrm{~h}$. Purification by flash chromatography (10\% ethyl acetate/dichloromethane) gave the desired product $(0.066 \mathrm{~g}, 94 \%)$ as a yellow oil. $\mathrm{R}_{f} 0.3$ (100\% dichloromethane); ${ }^{1} \mathrm{H} \mathrm{NMR}\left(300 \mathrm{MHz}, \mathrm{CDCl}_{3}\right) \delta \mathrm{ppm} 8.76(\mathrm{br} \mathrm{s}, 1 \mathrm{H}), 7.86(\mathrm{~d}$, $J=7.6 \mathrm{~Hz}, 1 \mathrm{H}), 7.76-7.69(\mathrm{~m}, 2 \mathrm{H}), 7.63-7.59(\mathrm{~m}, 1 \mathrm{H}), 7.49-7.43(\mathrm{dt}, J=7.5,1.0 \mathrm{~Hz}, 1 \mathrm{H}), 7.40-7.29(\mathrm{~m}$, $3 \mathrm{H}), 6.90$ (br s, 1H), $3.88(\mathrm{t}, J=4.7 \mathrm{~Hz}, 2 \mathrm{H}), 3.62(\mathrm{dd}, J=5.6,4.7 \mathrm{~Hz}), 2.27$ (br s, $1 \mathrm{H}) ;{ }^{13} \mathrm{C} \mathrm{NMR}(75 \mathrm{MHz}$, $\left.\mathrm{CDCl}_{3}\right) \delta$ ppm 156.7, 143.7, 142.1, 139.2, 136.6, 131.0, 129.8, 129.7, 128.1, 128.0, 125.4, 121.3, 120.8, 119.8, 62.8, 42.8; IR (film): 3377, 1643, 1519, 1180, 1068, $717 \mathrm{~cm}^{-1}$; LRMS m/z (relative intensity): 220.0637 (14.0\%), $179.0735(9.8 \%)$. 
<smiles>O=C(N/N=C/c1ccc(C(F)(F)F)cc1)N1CCC(c2ccccc2)CC1</smiles>

\section{4-Phenyl- $N^{\prime}$-(4-(trifluoromethyl)benzylidene)piperidine-1-carbohydrazide (4d)}

Synthesized according to general procedure 2 using phenyl 2-(4(trifluoromethyl)benzylidene)hydrazinecarboxylate $(0.077 \mathrm{~g}, 0.025 \mathrm{mmol})$, 4-phenylpiperidine $(0.202 \mathrm{~g}$, $1.25 \mathrm{mmol}), \mathrm{PhCF}_{3}(1.25 \mathrm{~mL})$, room temperature, $16 \mathrm{~h}$. Purification by flash chromatography (10\% ethyl acetate/dichloromethane) afforded the desired product $(0.087 \mathrm{~g}, 93 \%)$ as a white solid. $\mathrm{R}_{f} 0.15$ (10\% ethyl acetate/dichloromethane); ${ }^{1} \mathrm{H}$ NMR $\left(300 \mathrm{MHz}, \mathrm{CDCl}_{3}\right) \delta \mathrm{ppm} 8.32(\mathrm{br} \mathrm{s}, 1 \mathrm{H}), 7.89$ (br s, $\left.1 \mathrm{H}\right), 7.75(\mathrm{~d}, J=$ $8.1 \mathrm{~Hz}, 2 \mathrm{H}), 7.63(\mathrm{~d}, J=8.1 \mathrm{~Hz}, 2 \mathrm{H}), 7.37-7.32(\mathrm{~m}, 2 \mathrm{H}), 7.26-7.21(\mathrm{~m}, 3 \mathrm{H}), 4.44(\mathrm{~d}, J=13.2 \mathrm{~Hz}, 2 \mathrm{H}), 3.05$ (td, $J=12.6,2.4 \mathrm{~Hz}, 2 \mathrm{H}), 2.84-2.73(\mathrm{~m}, 1 \mathrm{H}), 1.98-1.73(\mathrm{~m}, 6 \mathrm{H}) ;{ }^{13} \mathrm{C} \mathrm{NMR}\left(75 \mathrm{MHz}, \mathrm{CDCl}_{3}\right) \delta \mathrm{ppm} 156.0$, $145.3,140.8,137.8,131.0(\mathrm{q}, J=32.6 \mathrm{~Hz}), 128.6,127.0,126.8,126.5,125.6(\mathrm{q}, J=3.7 \mathrm{~Hz}), 125.6(\mathrm{t}, J=$ $272.5 \mathrm{~Hz}$ ), 46.1, 42.8, 33.3; IR (film): 3442, 3225, 3060, 2936, 2853, 1644, 1556, 1410, 1324, 1278, 1237 , 1166, 1093, 841, $739 \mathrm{~cm}^{-1}$; HRMS (EI): Exact mass calcd for $\mathrm{C}_{20} \mathrm{H}_{20} \mathrm{~N}_{3} \mathrm{OF}_{3}[\mathrm{M}]^{+}: 375.1558$. Found: 375.1556.<smiles>CCCCCCNC(=O)N/N=C/c1ccccc1</smiles>

\section{2-Benzylidene- $N$-hexylhydrazinecarboxamide (2e)}

Synthesized according to general procedure 2 using phenyl 2-benzylidenehydrazinecarboxylate $(0.060 \mathrm{~g}$, $0.25 \mathrm{mmol}), n$-hexylamine $(0.096 \mathrm{~mL}, 0.50 \mathrm{mmol}), \mathrm{PhCF}_{3}(1.25 \mathrm{~mL})$, room temperature, $1 \mathrm{~h}$. Purification by flash chromatography (30\% ethyl acetate/petroleum ether) afforded the desired product $(0.061 \mathrm{~g}, 99 \%)$ as a white solid. $\mathrm{R}_{f} 0.19$ (30\% ethyl acetate/petroleum ether). Characterization data matches that reported for the same compound, synthesized via alternate route (see Table 2, entry 16).<smiles>O=C(N/N=C/c1cccs1)NC1CC1</smiles>

\section{$\mathrm{N}$-Cyclopropyl-2-(thiophen-2-ylmethylene)hydrazinecarboxamide (4e)}

Synthesized according to general procedure $\mathbf{2}$ using phenyl-2-(thiophen-2-ylmethylene) hydrazinecarboxylate $(0.061 \mathrm{~g}, 0.25 \mathrm{mmol})$, cyclopropylamine $(0.087 \mathrm{~mL}, 1.3 \mathrm{mmol})$, triethylamine $(0.039$ $\mathrm{mL}, 0.28 \mathrm{mmol}), \mathrm{PhCF}_{3}(1.25 \mathrm{~mL}), 80{ }^{\circ} \mathrm{C}$ for $4 \mathrm{~h}$. Purification by flash chromatography $(50 \%$ ethyl acetate/petroleum ether) afforded the desired product $(0.052 \mathrm{~g}, 99 \%)$ as a white solid. $\mathrm{R}_{f} 0.15$ (50 \% ethyl acetate/pet ether); ${ }^{1} \mathrm{H}$ NMR $\left(300 \mathrm{MHz}, \mathrm{CDCl}_{3}\right) \delta \mathrm{ppm} 10.13(\mathrm{~s}, 1 \mathrm{H}), 8.00(\mathrm{~s}, 1 \mathrm{H}), 7.31(\mathrm{dt}, J=5.1,0.9 \mathrm{~Hz}$, $1 \mathrm{H}), 7.02(\mathrm{dd}, J=3.6,1.2 \mathrm{~Hz}, 1 \mathrm{H}), 6.24(\mathrm{~s}, 1 \mathrm{H}), 2.76-2.70(\mathrm{~m}, 1 \mathrm{H}), 0.84-0.75(\mathrm{~m}, 2 \mathrm{H}), 0.64-0.62(\mathrm{~m}, 2 \mathrm{H})$; ${ }^{13} \mathrm{C}$ NMR $\left(75 \mathrm{MHz}, \mathrm{CDCl}_{3}\right) \delta \mathrm{ppm} 158.2(\mathrm{C}), 139.7(\mathrm{C}), 136.3(\mathrm{C}), 128.8(\mathrm{CH}), 127.2(\mathrm{CH}), 126.6(\mathrm{CH})$, $22.6(\mathrm{CH}), 6.8\left(2 \mathrm{CH}_{2}\right)$; IR (film) 3212, 3112, 3015, 2963, 1663, 1538, 1425, 1376, 1327, 1291, 1220, 1142, 927, $697 \mathrm{~cm}^{-1}$; HRMS (EI): Exact mass calcd for $\mathrm{C}_{9} \mathrm{H}_{11} \mathrm{~N}_{3} \mathrm{OS}$ [M] $]^{+}: 209.0623$. Found: 209.0619. 
<smiles>COc1ccc(/C(=N/NC(=O)N2CCCC2)C2CC2)cc1</smiles>

\section{$N^{\prime}$-(Cyclopropyl(4-methoxyphenyl)methylene)pyrrolidine-1-carbohydrazide (4f)}

Synthesized according to general procedure $\mathbf{3}$ using tert-butyl 2-(cyclopropyl(4methoxyphenyl)methylene)hydrazinecarboxylate $(0.10 \mathrm{mmol}, 0.029 \mathrm{~g})$, pyrrolidine $(0.50 \mathrm{mmol}, 0.041$ $\mathrm{mL}), \mathrm{PhCF}_{3}(1.0 \mathrm{~mL}), 150{ }^{\circ} \mathrm{C}, 1.5 \mathrm{~h}$. Purification by flash chromatography $(50 \%$ ethyl acetate/ dichloromethane) afforded the desired product $(0.028 \mathrm{~g}, 99 \%)$, a white solid as a mixture of isomers (1:1.6). ${ }^{1} \mathrm{H}$ NMR $\left(300 \mathrm{MHz}, \mathrm{CDCl}_{3}\right) \delta \mathrm{ppm} 8.40(\mathrm{~s}, 1 \mathrm{H}), 7.74(\mathrm{~d}, J=9.0 \mathrm{~Hz}, 2 \mathrm{H}), 6.76(\mathrm{~d}, J=9.0 \mathrm{~Hz}, 2 \mathrm{H}), 3.55-$ $3.51(\mathrm{~m}, 4 \mathrm{H}), 3.26(\mathrm{~s}, 3 \mathrm{H}), 1.32-1.28(\mathrm{~m}, 4 \mathrm{H}), 0.82-0.76(\mathrm{~m}, 1 \mathrm{H}), 0.43-0.37(\mathrm{~m}, 2 \mathrm{H}), 0.23-0.17(\mathrm{~m}, 2 \mathrm{H})$; ${ }^{13} \mathrm{C}$ NMR $\left(75 \mathrm{MHz}, \mathrm{CDCl}_{3}\right) \delta \mathrm{ppm} 160.1(\mathrm{C}), 155.0(\mathrm{C}), 146.0(\mathrm{C}), 130.6(\mathrm{C}), 128.4(2 \mathrm{CH})$ (overlaps with residual solvent peak), $113.6(2 \mathrm{CH}), 54.6\left(\mathrm{CH}_{3}\right), 47.6\left(2 \mathrm{CH}_{2}\right), 25.3\left(2 \mathrm{CH}_{2}\right), 6.8(\mathrm{CH}), 6.0\left(2 \mathrm{CH}_{2}\right)$; IR (film): 3450, 3385, 2963, 2926, 2872, 1653, 1607, 1507, 1250, 1174, 838, $752 \mathrm{~cm}^{-1}$; HRMS (EI): Exact mass calcd for $\mathrm{C}_{16} \mathrm{H}_{21} \mathrm{~N}_{3} \mathrm{O}_{2}[\mathrm{M}]^{+}:$287.1634. Found: 287.1619.<smiles>C=CCC/C(C)=N/NC(=O)N[C@@H](C)C(=O)OCC</smiles>

(S)-Ethyl 2-(2-(hex-5-enylidene)hydrazinecarboxamido)propanoate (4g)

Synthesized according to general procedure 2 using phenyl 2-(hex-5-enylidene)hydrazinecarboxylate $(0.500 \mathrm{mmol}, 0.116 \mathrm{~g})$, L-alanine ethyl ester hydrochloride $(2.50 \mathrm{mmol}, 0.384 \mathrm{~g})$, triethylamine $(2.6 \mathrm{mmol}$, $0.36 \mathrm{~mL})$, and $\mathrm{PhCF}_{3}(2.5 \mathrm{~mL}), 100{ }^{\circ} \mathrm{C}, 30 \mathrm{~min}$. After evaporation of solvent, water was added and extracted with dichloromethane (4 times). The combined organic layers were washed with water, dried over sodium sulfate and filtered. After evaporation of solvent, purification by flash chromatography (50\% ethyl acetate/petroleum ether) afforded the desired product $(0.090 \mathrm{~g}, 71 \%)$ as a clear, colorless oil; $\mathrm{R}_{f} 0.17$ (50\% ethyl acetate/petroleum ether); ${ }^{1} \mathrm{H}$ NMR $\left(\mathrm{CDCl}_{3}, 300 \mathrm{MHz}\right) \delta \mathrm{ppm} 7.99$ (br s, $\left.1 \mathrm{H}\right), 6.63(\mathrm{~d}, J=7.8$ $\mathrm{Hz}, 1 \mathrm{H}), 5.89-5.76(\mathrm{~m}, 1 \mathrm{H}), 5.08-4.96(\mathrm{~m}, 2 \mathrm{H}), 4.58-4.48(\mathrm{~m}, 1 \mathrm{H}), 4.20$ (quin, $J=7.2 \mathrm{~Hz}, 2 \mathrm{H}), 2.35-2.29$ $(\mathrm{m}, 4 \mathrm{H}), 1.80(\mathrm{~s}, 3 \mathrm{H}), 1.44(\mathrm{~d}, J=7.2 \mathrm{~Hz}, 3 \mathrm{H}), 1.25(\mathrm{t}, J=7.2 \mathrm{~Hz}, 3 \mathrm{H}) ;{ }^{13} \mathrm{C} \mathrm{NMR}\left(\mathrm{CDCl}_{3}, 75 \mathrm{MHz}\right) \delta \mathrm{ppm}$ 173.5, 156.0, 149.4, 137.6, 115.0, 61.1, 48.4, 37.8, 30.2, 18.9, 15.4, 14.1; IR (film):3209, 3097, 2985, 1739, 1670, 1523, 1165, $910 \mathrm{~cm}^{-1}$; HRMS (EI): Exact mass calcd for $\mathrm{C}_{12} \mathrm{H}_{21} \mathrm{~N}_{3} \mathrm{O}_{3}$ [M]+: 255.1583. Found: 255.15879 . 


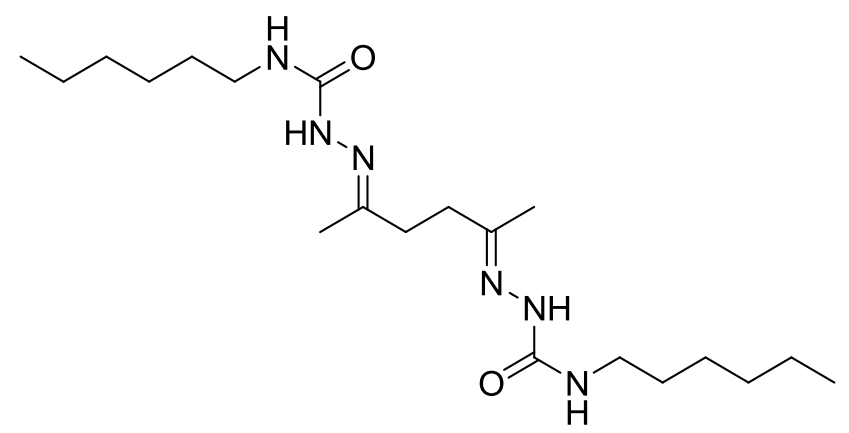

2,2'-(Hexane-2,5-diylidene)bis( $N$-hexylhydrazinecarboxamide) (5f)

Synthesized according to general procedure 2 using diphenyl 2,2'-(hexane-2,5diylidene)bis(hydrazinecarboxylate) $(0.23 \mathrm{mmol}, 0.090 \mathrm{~g})$, hexylamine $(1.2 \mathrm{mmol}, 0.22 \mathrm{~mL})$, dichloromethane $(2 \mathrm{~mL}), 30 \mathrm{~min}$, room temperature. Purification by flash chromatography (50\% ethylacetate/petroleum ether, then $100 \%$ ethyl acetate) afforded the desired product $(0.089 \mathrm{~g}, 96 \%)$ as a yellow oil. $\mathrm{R}_{f} 0.1$ (50\% ethyl acetate/petroleum ether); ${ }^{1} \mathrm{H} \mathrm{NMR}\left(300 \mathrm{MHz}, \mathrm{CDCl}_{3}\right) \delta \mathrm{ppm} 8.11(\mathrm{br} \mathrm{s}, 2 \mathrm{H})$, $6.11(\mathrm{t}, J=5.85,2 \mathrm{H}), 2.68(\mathrm{dd}, J=13.4,6.5,4 \mathrm{H}), 2.48(\mathrm{~s}, 4 \mathrm{H}), 1.84(\mathrm{~s}, 6 \mathrm{H}), 1.58-149(\mathrm{~m}, 4 \mathrm{H}), 1.36-1.25$ $(\mathrm{m}, 12 \mathrm{H}), 0.90-0.86(\mathrm{~m}, 6 \mathrm{H}) ;{ }^{13} \mathrm{C}$ NMR $\left(75 \mathrm{MHz}, \mathrm{CDCl}_{3}\right) \delta \mathrm{ppm} 156.6,148.2,39.7,35.0,31.5,30.2,26.5$, 22.5, 15.4, 14.0; IR (film): 3234, 2927, 1706, 1527, 1247, 1155, $732 \mathrm{~cm}^{-1}$; LRMS m/z (relative intensity): $238.1925(10.9 \%), 168.1013(10.6 \%), 100.1128(1.3 \%)$.<smiles>O=C(NNC(=O)c1ccccc1)Oc1ccccc1</smiles>

\section{Phenyl 2-benzoylhydrazinecarboxylate (6a)}

To a round bottom charged with magnetic stirrer was added phenylcarbazate $(0.609 \mathrm{~g}, 4.00 \mathrm{mmol})$, benzoyl chloride $(0.46 \mathrm{~mL}, 4.0 \mathrm{mmol}), 1,4$-dioxane $(20 \mathrm{~mL})$, and sodium bicarbonate $(0.403 \mathrm{~g}, 4.8 \mathrm{mmol})$. The reaction was stirred at room temperature for $1 \mathrm{~h}$, and quenched with water. The resulting aqueous solution was extracted with diethylether, dried over sodium sulfate, and filtered. The solution was concentrated under reduced pressure to yield the desired product $(0.93 \mathrm{~g}, 91)$ as a white solid. $\mathrm{R}_{f} 0.62$ (50\% ethyl acetate/petroleum ether). ${ }^{1} \mathrm{H}$ NMR $\left(300 \mathrm{MHz}, \mathrm{CDCl}_{3}\right) \delta \mathrm{ppm} 8.19$ (brs, 1H), 8.11-8.08 (m, $\left.2 \mathrm{H}\right), 7.83-7.81$ $(\mathrm{m}, 2 \mathrm{H}), 7.62-7.58(\mathrm{~m}, 1 \mathrm{H}), 7.56-7.52(\mathrm{~m}, 1 \mathrm{H}), 7.48-7.42(\mathrm{~m}, 2 \mathrm{H}), 7.37-7.33(\mathrm{~m}, 1 \mathrm{H}), 7.24-7.20(\mathrm{~m}, 2 \mathrm{H})$; ${ }^{13} \mathrm{C}$ NMR $\left(75 \mathrm{MHz}, \mathrm{CDCl}_{3}\right) \delta \mathrm{ppm} 171.2,167.4,155.3,150.5,133.7,132.6,130.2,129.4,128.7,128.5$, 127.5, 125.9, 121.3; HRMS (EI): Exact mass calcd for $\mathrm{C}_{14} \mathrm{H}_{12} \mathrm{~N}_{2} \mathrm{O}_{3}[\mathrm{M}]+:$ 256.0848. Found: 256.0841.<smiles>O=C(NNC(=O)c1ccccc1)Nc1ccccc1</smiles>

\section{2-Benzoyl- $N$-hexylhydrazinecarboxamide (6b)}

To a round bottom charged with magnetic stirrer was added phenyl 2-benzoylhydrazinecarboxylate (0.064 $\mathrm{g}, 0.25 \mathrm{mmol}), n$-hexylamine $(0.096 \mathrm{~mL}, 0.50 \mathrm{mmol}), \mathrm{PhCF}_{3}(1.25 \mathrm{~mL})$. The reaction irradiated in the microwave to a temperature of $80{ }^{\circ} \mathrm{C}$ for $1 \mathrm{~h}$. Purification by flash chromatography (50\% to $70 \%$ ethyl acetate/petroleum ether) afforded the desired product $(0.63 \mathrm{~g}, 96 \%)$ as a white solid. $\mathrm{R}_{f} 0.22$ (70\% ethyl acetate/petroleum ether). ${ }^{1} \mathrm{H}$ NMR $\left(300 \mathrm{MHz}, \mathrm{CDCl}_{3}\right) \delta \mathrm{ppm} 9.96(\mathrm{~s}, 1 \mathrm{H}), 8.17$ (brs, $\left.1 \mathrm{H}\right), 7.88-7.85$ (m, 2H), 7.47-7.42 (m, 1H), 7.36-7.30 (m, 2H), 6.07 (brs, $1 \mathrm{H}), 3.00$ (brs, $2 \mathrm{H}), 1.35-1.17$ (m, 8H), 0.84-0.79 (m, $3 \mathrm{H}) ;{ }^{13} \mathrm{C} \mathrm{NMR}\left(75 \mathrm{MHz}, \mathrm{CDCl}_{3}\right) \delta \mathrm{ppm} 167.3,158.9,132.1,131.4,130.0,128.5,128.3,127.6,40.3,31.5$, 29.8, 26.5, 22.5, 14.0; HRMS (EI): Exact mass calcd for $\mathrm{C}_{14} \mathrm{H}_{21} \mathrm{~N}_{3} \mathrm{O}_{2}$ [M]+: 263.1634. Found: 263.1647. 
<smiles>CCN(CC)C(=O)NNC(=O)c1ccccc1</smiles>

\section{2-Benzoyl- $N, N$-diethylhydrazinecarboxamide (6c)}

To a round bottom charged with magnetic stirrer was added phenyl 2-benzoylhydrazinecarboxylate (0.064 $\mathrm{g}, 0.25 \mathrm{mmol})$, diethylamine $(0.052 \mathrm{~mL}, 0.50 \mathrm{mmol}), \mathrm{PhCF}_{3}(1.25 \mathrm{~mL})$. The reaction irradiated in the microwave to a temperature of $100{ }^{\circ} \mathrm{C}$ for $1 \mathrm{~h}$. Purification by flash chromatography (50\% ethyl acetate/ dichloromethane) afforded the desired product $(0.051 \mathrm{~g}, 86 \%)$ as a white solid. $\mathrm{R}_{f} 0.28$ (50\% ethyl acetate/dichloromethane). ${ }^{1} \mathrm{H}$ NMR $\left(300 \mathrm{MHz}, \mathrm{CDCl}_{3}\right) \delta \mathrm{ppm} 9.61$ (brs, $\left.1 \mathrm{H}\right), 7.85-7.82(\mathrm{~m}, 2 \mathrm{H}), 7.48-7.45$ $(\mathrm{m}, 1 \mathrm{H}), 7.43-7.40(\mathrm{~m}, 1 \mathrm{H}), 7.36-7.30(\mathrm{~m}, 2 \mathrm{H}), 3.29(\mathrm{q}, J=7.2 \mathrm{~Hz}, 4 \mathrm{H}), 1.16(\mathrm{t}, J=7.0 \mathrm{~Hz}, 6 \mathrm{H}) ;{ }^{13} \mathrm{C} \mathrm{NMR}$ $\left(75 \mathrm{MHz}, \mathrm{CDCl}_{3}\right) \delta \mathrm{ppm}$ 166.0, 157.1, 131.8, 128.4, 127.3, 41.5, 13.6; HRMS (EI): Exact mass calcd for $\mathrm{C}_{12} \mathrm{H}_{17} \mathrm{~N}_{3} \mathrm{O}_{2}[\mathrm{M}]+:$ 235.1321. Found: 235.1317.<smiles>CN(N=C1c2ccccc2-c2ccccc21)C(=O)OC(C)(C)C</smiles>

\section{tert-Butyl 2-(9H-fluoren-9-ylidene)-1-methylhydrazinecarboxylate (7a)}

To a round bottom charged with magnetic stirrer was added tert-butyl 2-(9H-fluoren-9-ylidene) hydrazinecarboxylate $(0.063 \mathrm{~g}, 0.21 \mathrm{mmol})$ and THF $(1 \mathrm{~mL})$. The solution was cooled to $0{ }^{\circ} \mathrm{C}$ and $\mathrm{Et}_{4} \mathrm{NOH}-5 \mathrm{H}_{2} \mathrm{O}(0.054 \mathrm{~g}, 0.30 \mathrm{mmol})$ was added. After stirring for $30 \mathrm{~min}$ at $0{ }^{\circ} \mathrm{C}, \mathrm{Me}-\mathrm{I}(0.043 \mathrm{~g}, 0.30$ mmol) was added. After $30 \mathrm{~min}$ the reaction was warmed to room temperature and stirred for $16 \mathrm{~h}$. The reaction was quenched with $\mathrm{H}_{2} \mathrm{O}$ and extracted with dichloromethane (three times). The combined organic layers were dried over sodium sulfate, filtered and concentrated under reduced pressure to give the desired product $(0.063 \mathrm{~g}, 95 \%)$ as a yellow solid. $\mathrm{R}_{f} 0.4\left(10 \%\right.$ ethyl acetate/ petroleum ether). ${ }^{1} \mathrm{H}$ NMR $\left(300 \mathrm{MHz}, \mathrm{CDCl}_{3}\right) \delta \mathrm{ppm} 7.86(\mathrm{~d}, \mathrm{~J}=6.9 \mathrm{~Hz}, 1 \mathrm{H}), 7.83(\mathrm{~d}, \mathrm{~J}=7.3 \mathrm{~Hz}, 1 \mathrm{H}), 7.42-7.37(\mathrm{~m}, 2 \mathrm{H})$, 7.29-7.21 (m, 2H), $3.37(\mathrm{~s}, 3 \mathrm{H}), 1.37(\mathrm{~s}, 9 \mathrm{H})$. Characterization data matches that reported in the literature. ${ }^{66}$<smiles>CN(N=C1c2ccccc2-c2ccccc21)C(=O)Oc1ccccc1</smiles>

\section{Phenyl 2-(9H-fluoren-9-ylidene)-1-methylhydrazinecarboxylate (7b)}

To a round bottom charged with magnetic stirrer was added phenyl 2-(9H-fluoren-9-ylidene) hydrazinecarboxylate $(0.063 \mathrm{~g}, 0.20 \mathrm{mmol})$ and $\mathrm{THF}(1 \mathrm{~mL})$. The solution was cooled to $0{ }^{\circ} \mathrm{C}$ and $\mathrm{Et}_{4} \mathrm{NOH}-$ $5 \mathrm{H}_{2} \mathrm{O}(0.054 \mathrm{~g}, 0.30 \mathrm{mmol})$ was added. The reaction was stirred for $30 \mathrm{~min}$ at $0{ }^{\circ} \mathrm{C}$, then $\mathrm{MeI}(0.043 \mathrm{~g}$, $0.30 \mathrm{mmol}$ ) was added. After $30 \mathrm{~min}$ the reaction was allowed to warm to room temperature and stir for 6 h. The reaction was quenched with $\mathrm{H}_{2} \mathrm{O}$ and extracted with dichloromethane (three times). The combined organic layers were dried over sodium sulfate, filtered and concentrated under reduced pressure. Purification by flash chromatography (10\% ethyl acetate/ petroleum ether) afforded the desired product $(0.026 \mathrm{~g}, 40 \%)$ as a white solid. $\mathrm{R}_{f} 0.15$ (10\% ethyl acetate/ petroleum ether). ${ }^{1} \mathrm{H} \mathrm{NMR}\left(300 \mathrm{MHz}, \mathrm{CDCl}_{3}\right)$ $\delta$ ppm $7.98(\mathrm{~d}, \mathrm{~J}=8.1 \mathrm{~Hz}, 1 \mathrm{H}), 7.92(\mathrm{~d}, \mathrm{~J}=6.8 \mathrm{~Hz}, 1 \mathrm{H}), 7.58(\mathrm{dd}, \mathrm{J}=7.9,7.6 \mathrm{~Hz}, 2 \mathrm{H}), 7.49-7.40(\mathrm{~m}, 2 \mathrm{H})$, 7.34-7.24 (m, 4H), 7.17-7.12 (m, 1H), 7.02 (d, J = 6.5 Hz, 2H), $3.53(\mathrm{~s} .3 \mathrm{H}) ;{ }^{13} \mathrm{C}$ NMR $\left(75 \mathrm{MHz}, \mathrm{CDCl}_{3}\right)$ $\delta$ ppm 167.6, 153.1, 151.1, 143.1, 141.4, 136.2, 132.8, 132.1, 130.6, 129.2, 128.7, 128.5, 127.6, 125.5, 
123.4, 121.7, 120.4, 119.7, 38.1. IR (film): 2990, 1745, 1481, 1137, $764 \mathrm{~cm}^{-1}$; HRMS (EI): Exact mass calcd for $\mathrm{C}_{21} \mathrm{H}_{16} \mathrm{~N}_{2} \mathrm{O}_{2}[\mathrm{M}]+:$ 328.1212. Found: 328.1219 .<smiles>COC(=O)NN=C1c2ccccc2-c2ccccc21</smiles>

Methyl 2-(9H-fluoren-9-ylidene)hydrazinecarboxylate (7d)

To a round bottom charged with magnetic stirrer was added phenyl 2-(9H-fluoren-9-ylidene) hydrazinecarboxylate $(0.314 \mathrm{~g}, 1.00 \mathrm{mmol})$ and THF $(5 \mathrm{~mL})$. The solution was cooled to $0{ }^{\circ} \mathrm{C}$ and $25 \%$ $\mathrm{Et}_{4} \mathrm{NOH}$ in methanol $(0.585 \mathrm{~g}, 1.50 \mathrm{mmol})$ was added. The reaction was stirred for $30 \mathrm{~min}$ at $0{ }^{\circ} \mathrm{C}$, then 2bromoacetamide $(0.2 .07 \mathrm{~g}, 1.50 \mathrm{mmol})$ was added. After $30 \mathrm{~min}$ the reaction was allowed to warm to room temperature and stir for $16 \mathrm{~h}$. The reaction was quenched with $\mathrm{H}_{2} \mathrm{O}$ and extracted with dichloromethane (three times). The combined organic layers were dried over sodium sulfate, filtered and concentrated under reduced pressure. Purification by flash chromatography ( $20 \%$ ethyl acetate/ petroleum ether) afforded the product $(0.219 \mathrm{~g}, 87 \%)$ as a white solid. $\mathrm{R}_{f} 0.20$ (20\% ethyl acetate/ petroleum ether). ${ }^{1} \mathrm{H}$ NMR (300 $\left.\mathrm{MHz}, \mathrm{CDCl}_{3}\right) \delta$ ppm8.90 (brs, $\left.1 \mathrm{H}\right), 7.87(\mathrm{~d}, \mathrm{~J}=8.0 \mathrm{~Hz}, 1 \mathrm{H}, 7.75(\mathrm{~d}, \mathrm{~J}=6.3 \mathrm{~Hz}, 1 \mathrm{H}), 7.66(\mathrm{~d}, \mathrm{~J}=6.8 \mathrm{~Hz}$, $1 \mathrm{H}), 7.55(\mathrm{~d}, \mathrm{~J}=8.5 \mathrm{~Hz}, 1 \mathrm{H}), 7.44-7.24(\mathrm{~m}, 4 \mathrm{H}), 3.92(\mathrm{~s}, 3 \mathrm{H}) ;{ }^{13} \mathrm{C} \mathrm{NMR}\left(75 \mathrm{MHz}, \mathrm{CDCl}_{3}\right) \delta \mathrm{ppm} \mathrm{154.6,}$ 147.1, 142.4, 139.3 136.7, 131.2, 129.9, 129.7, 128.3, 127.9, 125.3, 122.3, 120.9, 119.6, 53.4; HRMS (EI): Exact mass calcd for $\mathrm{C}_{15} \mathrm{H}_{12} \mathrm{~N}_{2} \mathrm{O}_{2}[\mathrm{M}]+:$ 252.0899. Found: 252.0907 .<smiles>NC(=O)CN(N=C1c2ccccc2-c2ccccc21)C(=O)c1ccccc1</smiles>

Phenyl 1-(2-amino-2-oxoethyl)-2-(9H-fluoren-9-ylidene)hydrazinecarboxylate (7c)

To a round bottom flask charged with magnetic stirrer was added phenyl 2-(9H-fluoren-9-ylidene) hydrazinecarboxylate $(0.059 \mathrm{~g}, 0.20 \mathrm{mmol})$ and THF $(1 \mathrm{~mL})$. The solution was cooled to $0{ }^{\circ} \mathrm{C}$ and $25 \%$ $\mathrm{Et}_{4} \mathrm{NOH}$ in $\mathrm{H}_{2} \mathrm{O}(0.18 \mathrm{~g}, 0.30 \mathrm{mmol})$ was added. After stirring for $30 \mathrm{~min}$ at $0{ }^{\circ} \mathrm{C}$, bromoacetamide $(0.041$ $\mathrm{g}, 0.30 \mathrm{mmol}$ ) was added. After $30 \mathrm{~min}$ the reaction was warmed to room temperature and stirred for $16 \mathrm{~h}$. Purification by flash chromatography ( $20 \%$ then $50 \%$ ethyl acetate/ petroleum ether) afforded the desired product $(0.034 \mathrm{~g}, 62 \%)$ as a white solid. $\mathrm{R}_{f} 0.2\left(50 \%\right.$ ethyl acetate/ petroleum ether). ${ }^{1} \mathrm{H} \mathrm{NMR}(300 \mathrm{MHz}$, $\left.\mathrm{CDCl}_{3}\right) \delta \mathrm{ppm} 7.82-7.77(\mathrm{~m}, 2 \mathrm{H}), 7.57(\mathrm{q}, \mathrm{J}=6.8 \mathrm{~Hz}, 2 \mathrm{H}), 7.45-7.38(\mathrm{~m}, 2 \mathrm{H}), 7.29-7.22(\mathrm{~m}, 2 \mathrm{H}), 6.56$ (brs, $1 \mathrm{H}), 5.73$ (brs, 1H), 4.41 (s, 2H), $1.39(\mathrm{~s}, 9 \mathrm{H}) ;{ }^{13} \mathrm{C} \mathrm{NMR}\left(75 \mathrm{MHz}, \mathrm{CDCl}_{3}\right) \delta \mathrm{ppm} \mathrm{168.2,} \mathrm{166.1,} \mathrm{152.8,}$ 143.1, 141.2, 136.2, 134.7, 132.6, 131.9, 128.5, 128.4, 127.7, 123.3, 120.4, 119.9, 83.0, 55.2, 28.1. HRMS (EI): Exact mass calcd for $\mathrm{C}_{20} \mathrm{H}_{21} \mathrm{~N}_{3} \mathrm{O}_{3}[\mathrm{M}]+:$ 351.1583. Found: 351.1576 . 


\section{Appendix 1: NMR Spectra}
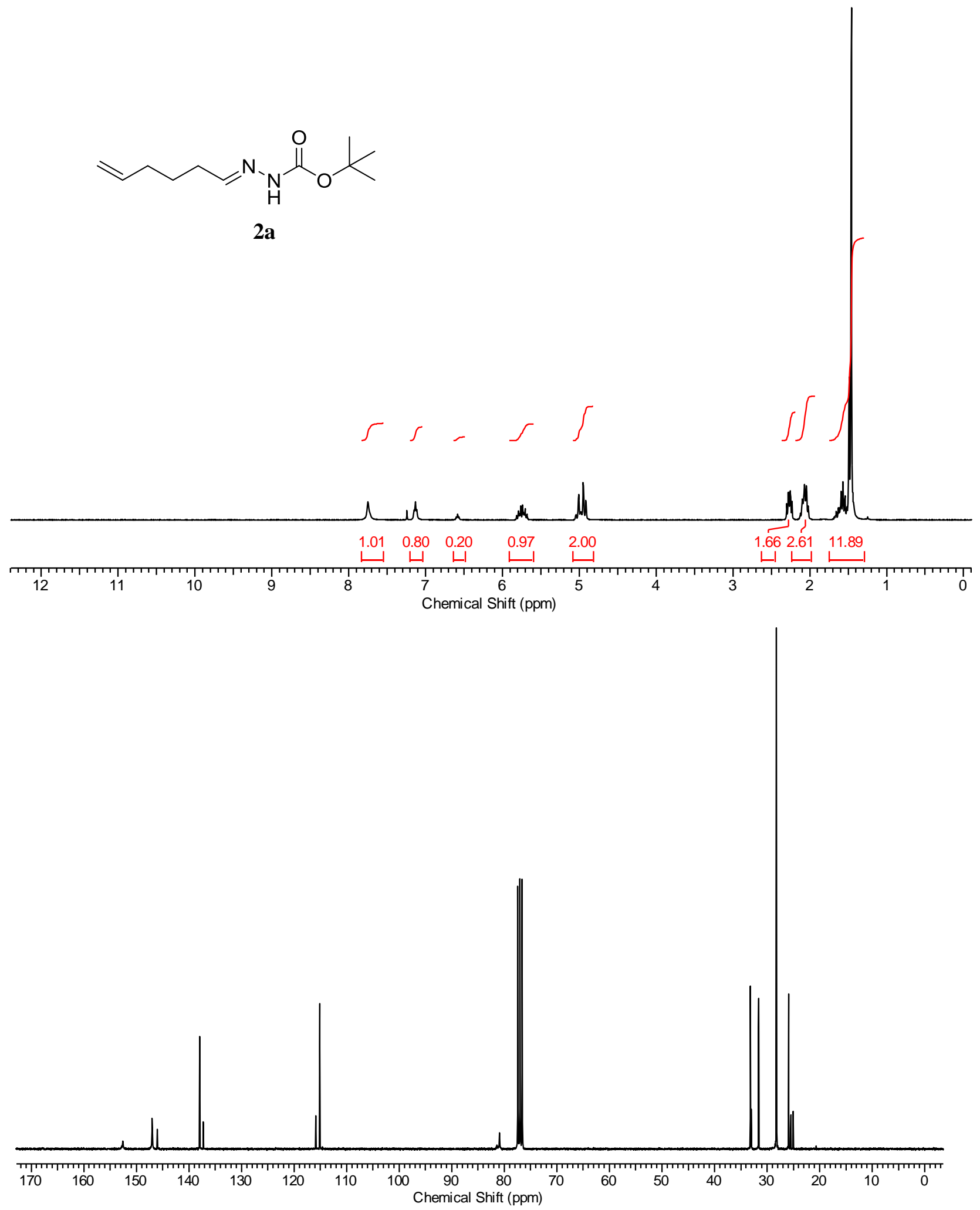


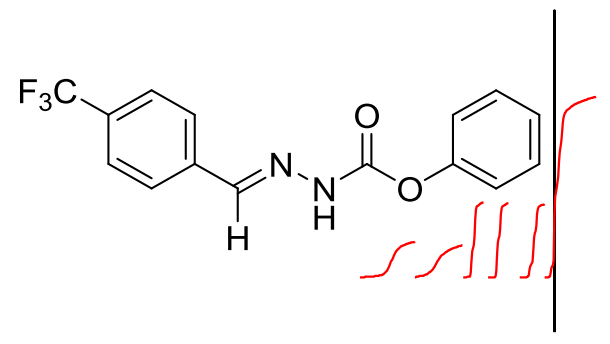

$4 a$
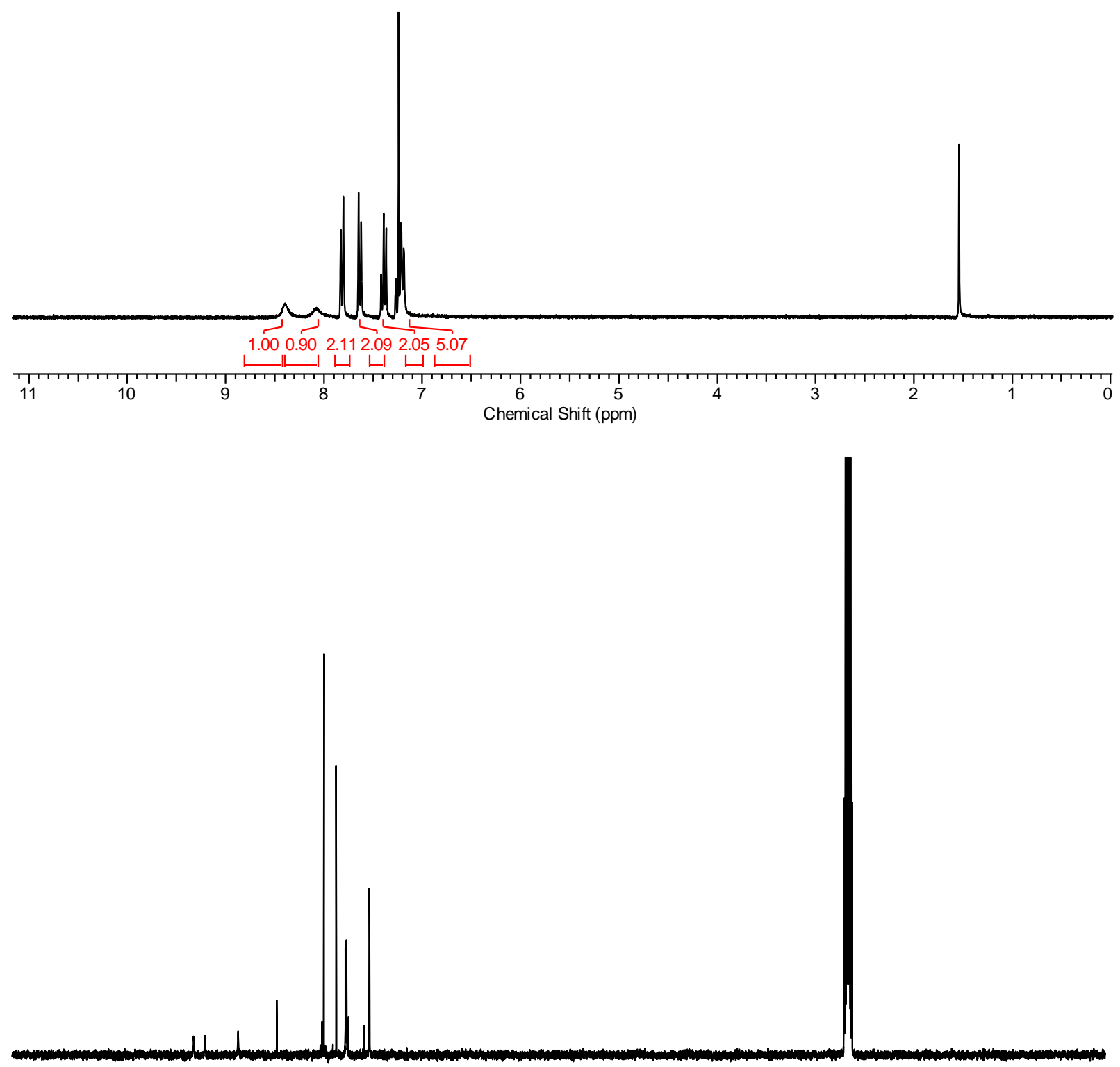

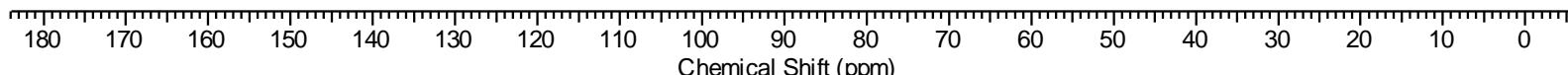




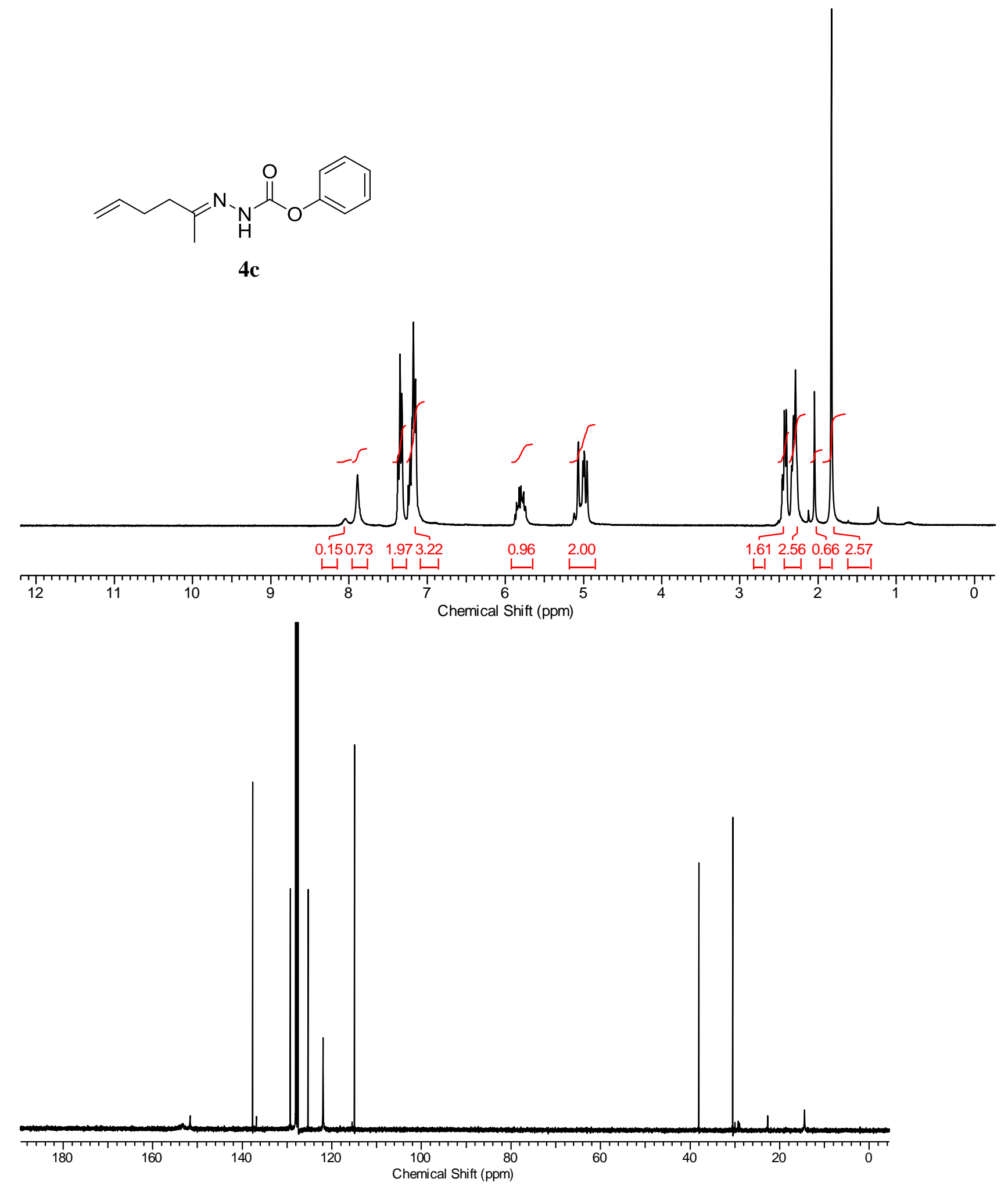



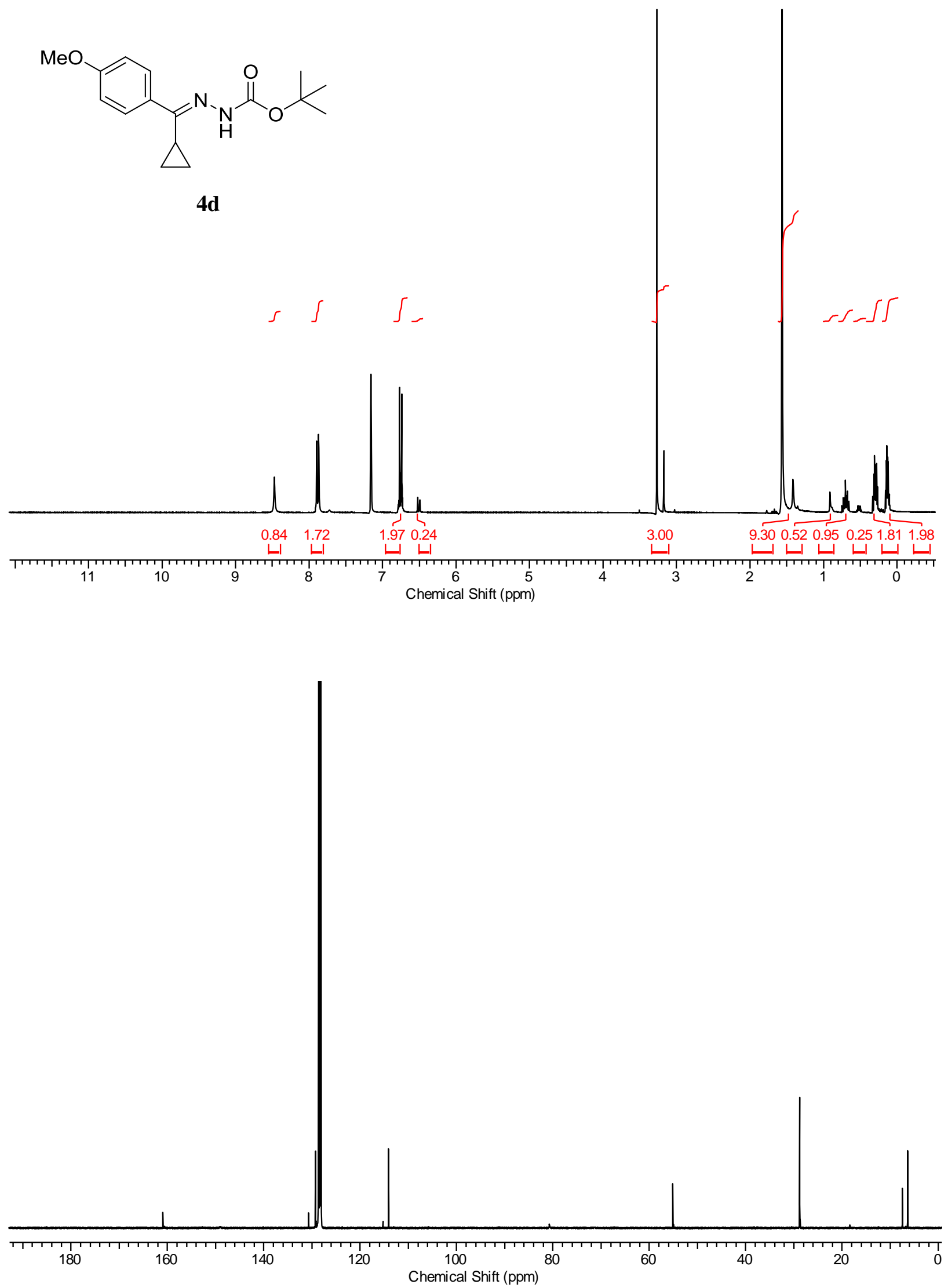

S81 

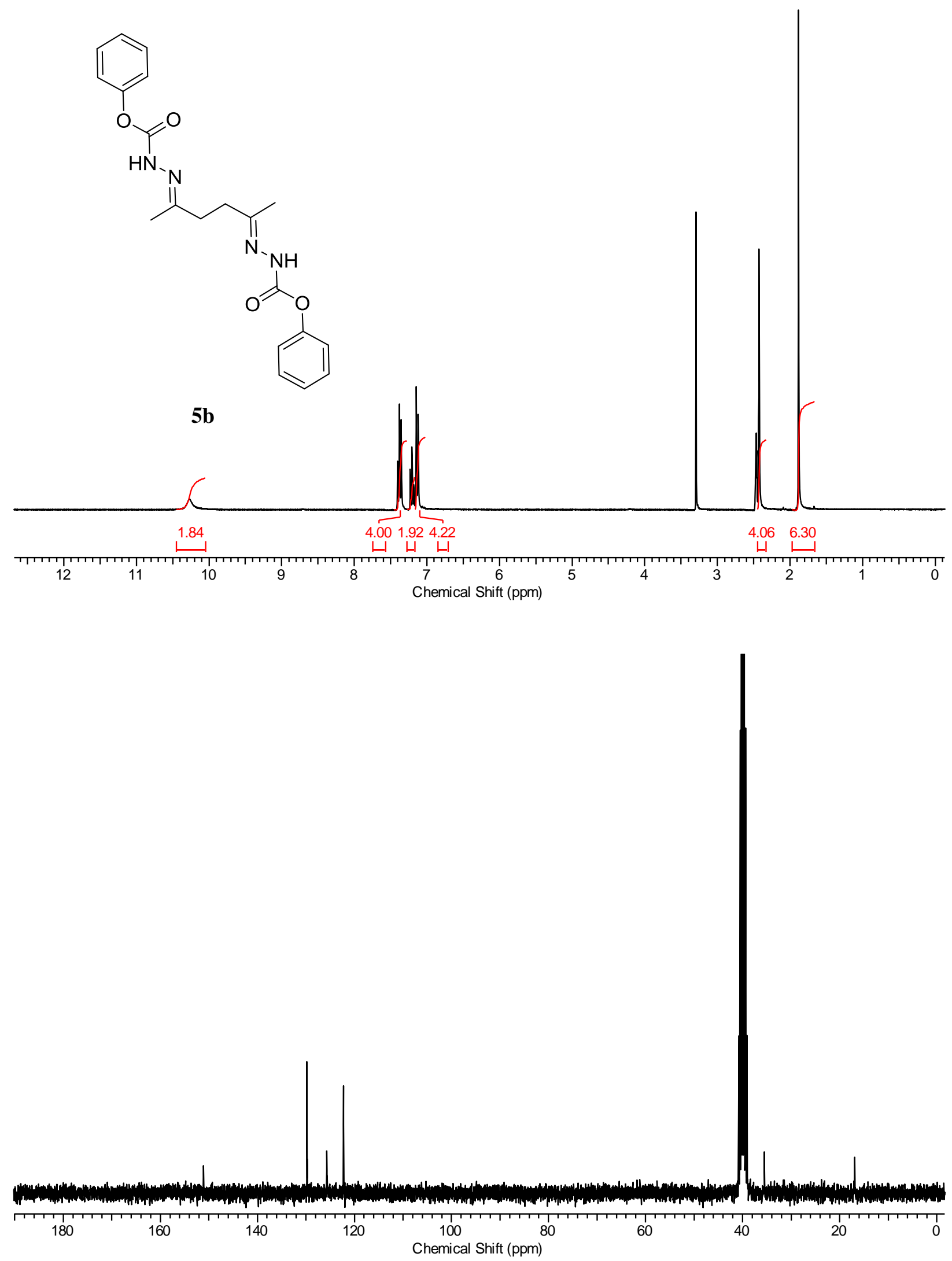


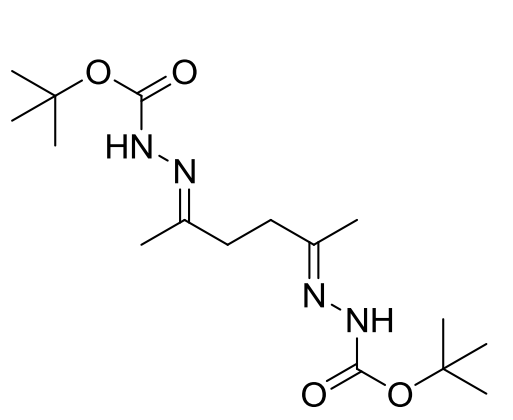

$5 a$
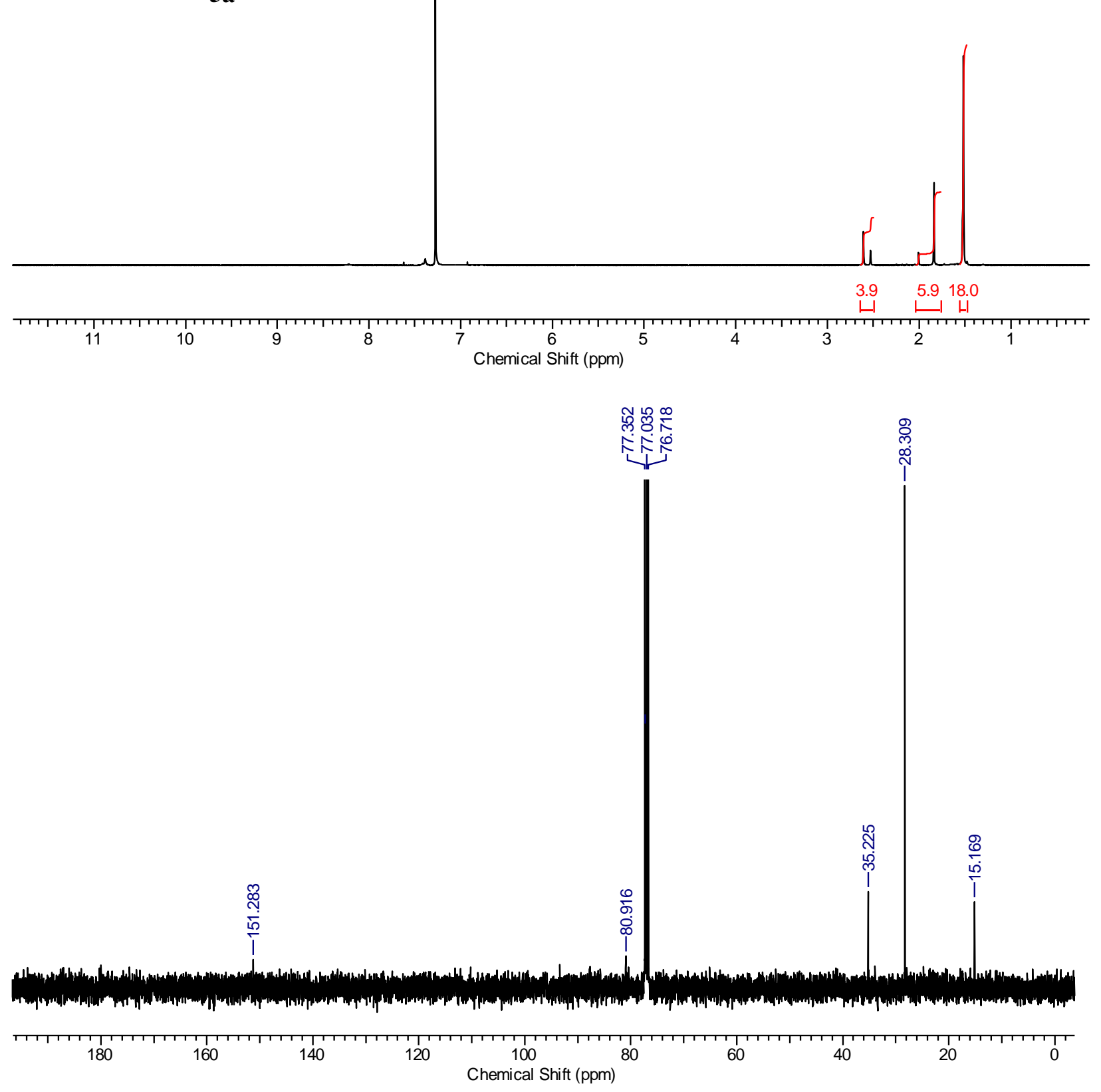
<smiles>CCCCCCNC(=O)NN=C(C(C)C)C(C)C</smiles>

1j

Table 2, 7, 11
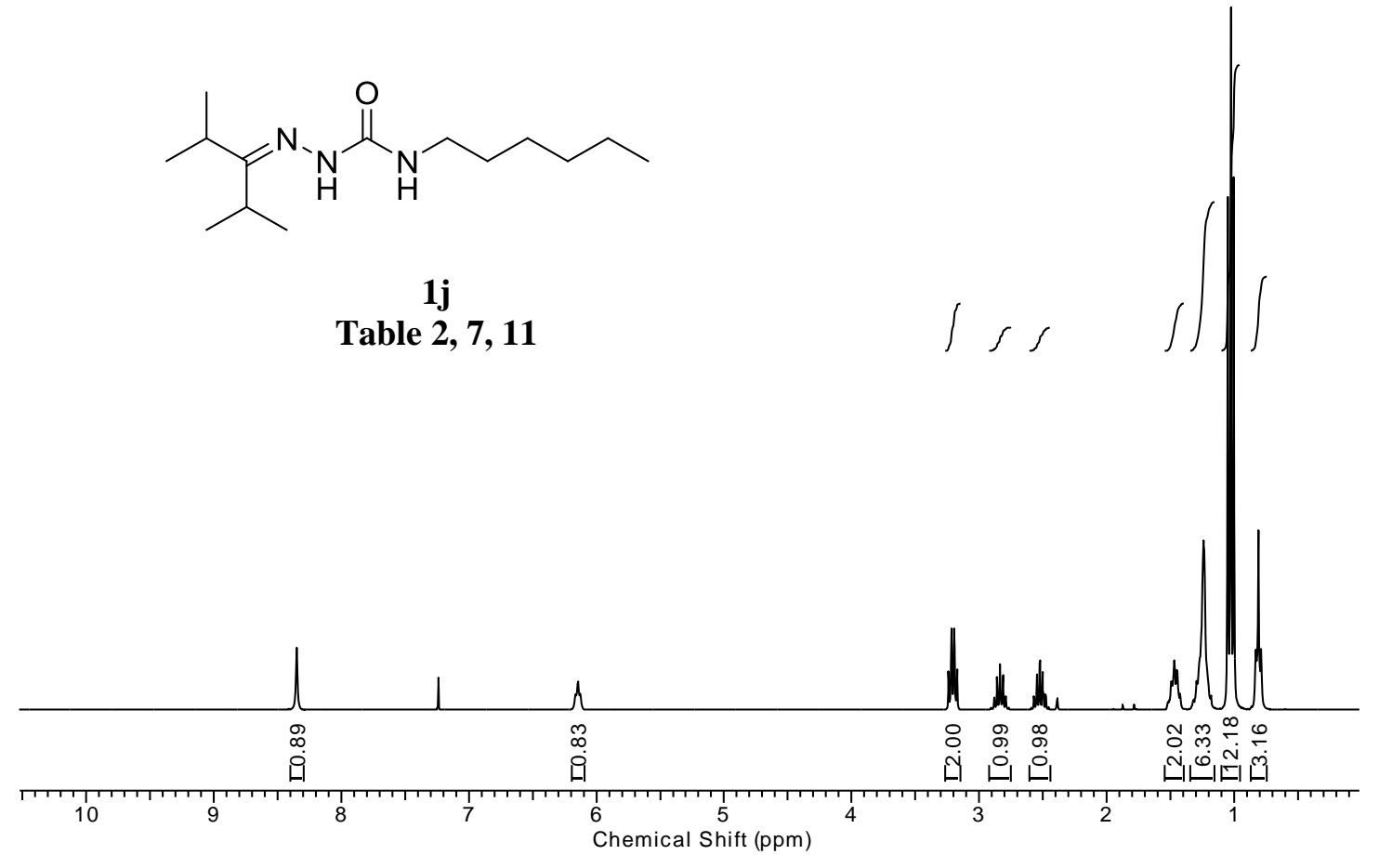

กิ่

ชิำ

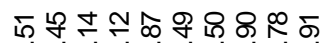

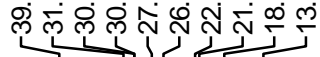

11

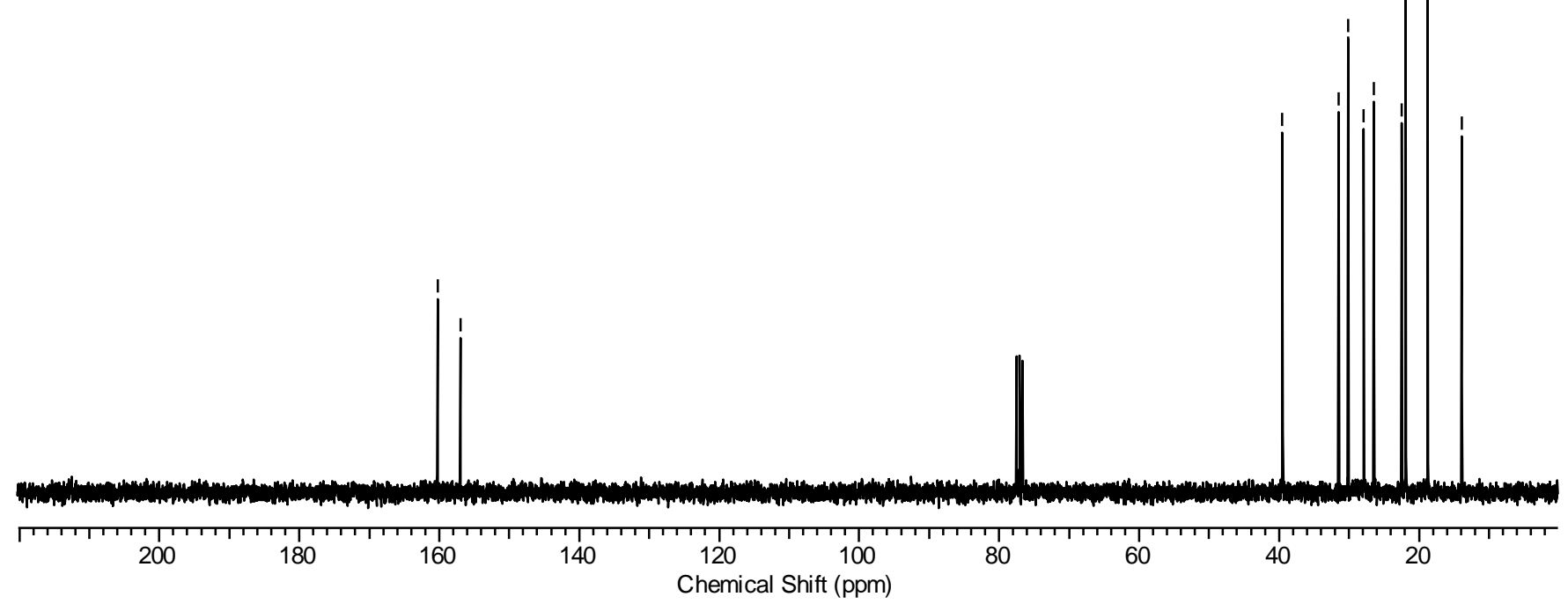


<smiles>CC(C)C(=NNC(=O)Nc1ccccc1)C(C)C</smiles>

1d

Table 2, 7, 10

$\iint J \int$

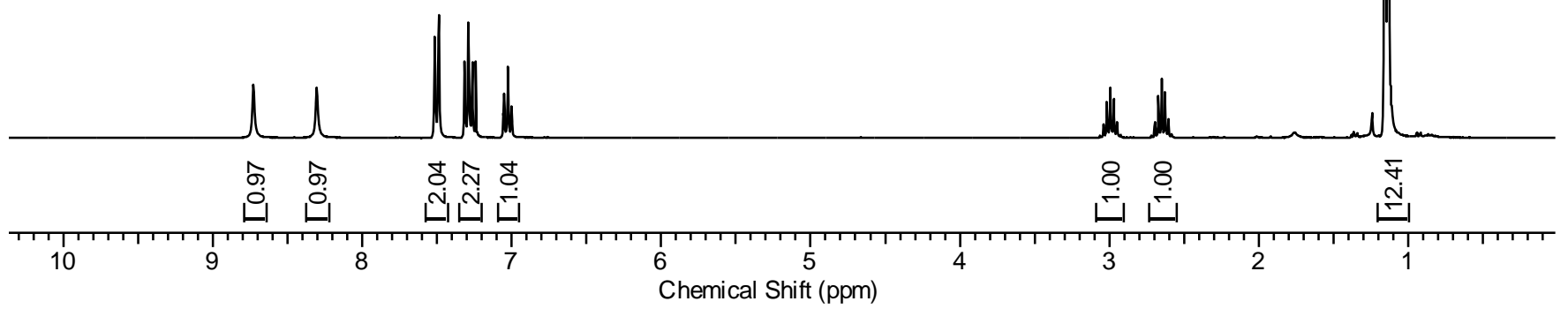

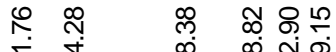

$$
\begin{aligned}
& \text { ए एँ }
\end{aligned}
$$

ำ กิ

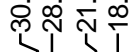

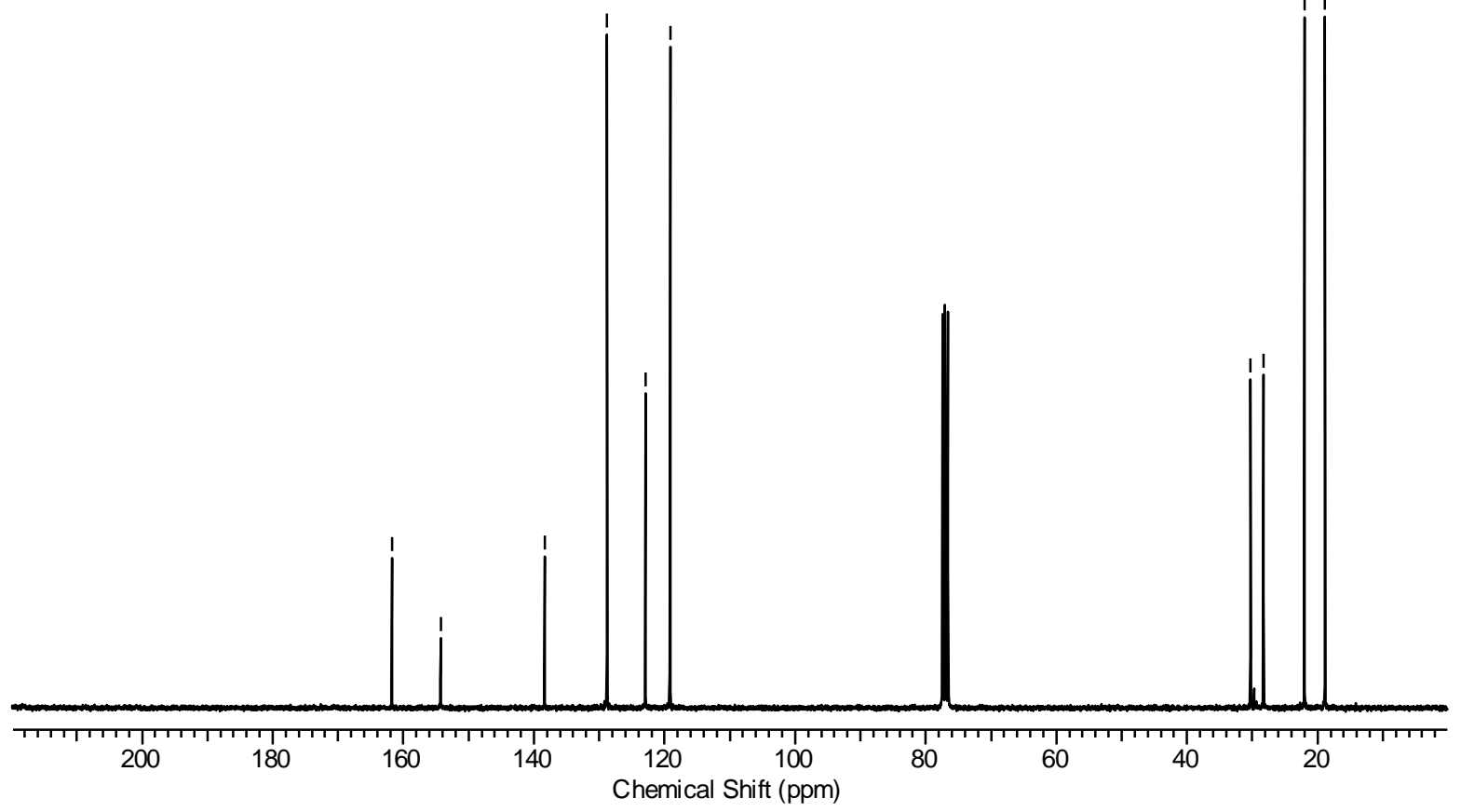


<smiles>CC(C)C(=NNC(=O)N1CCOCC1)C(C)C</smiles>

1e

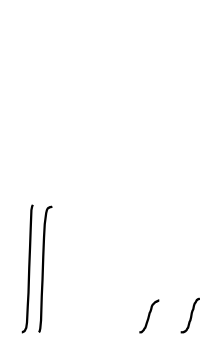

Table 2, 7, 10

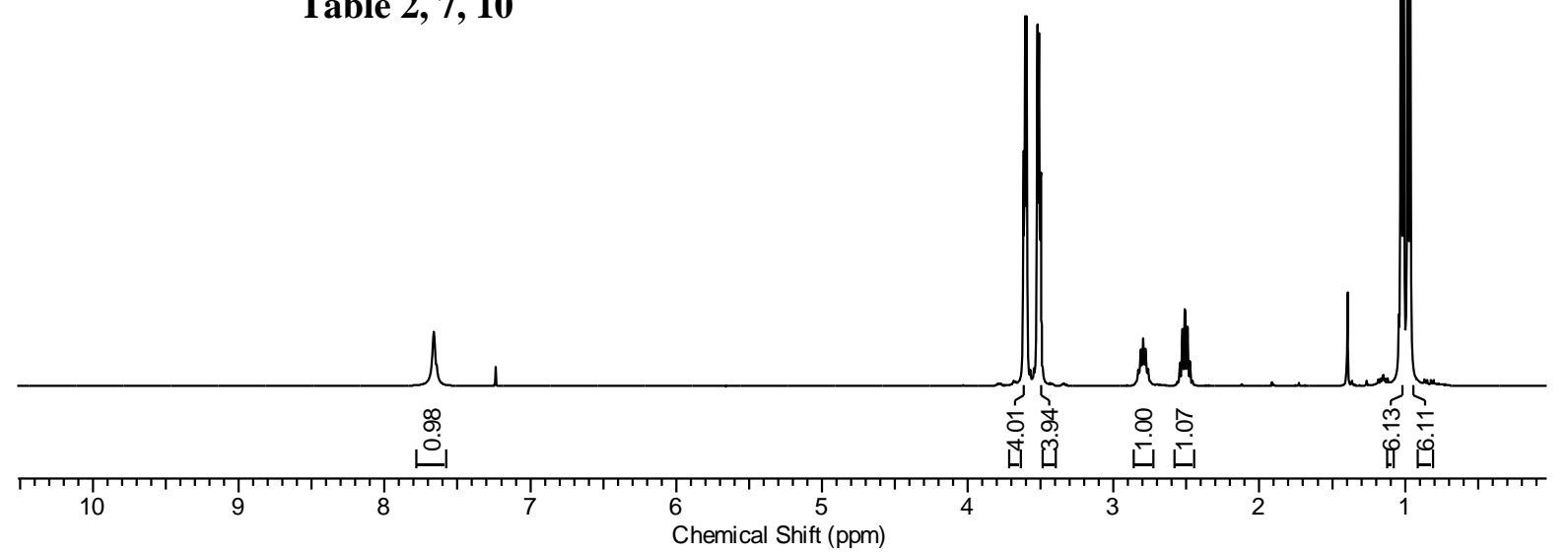

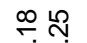

ชิ่

广

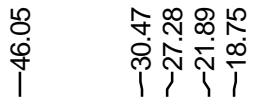

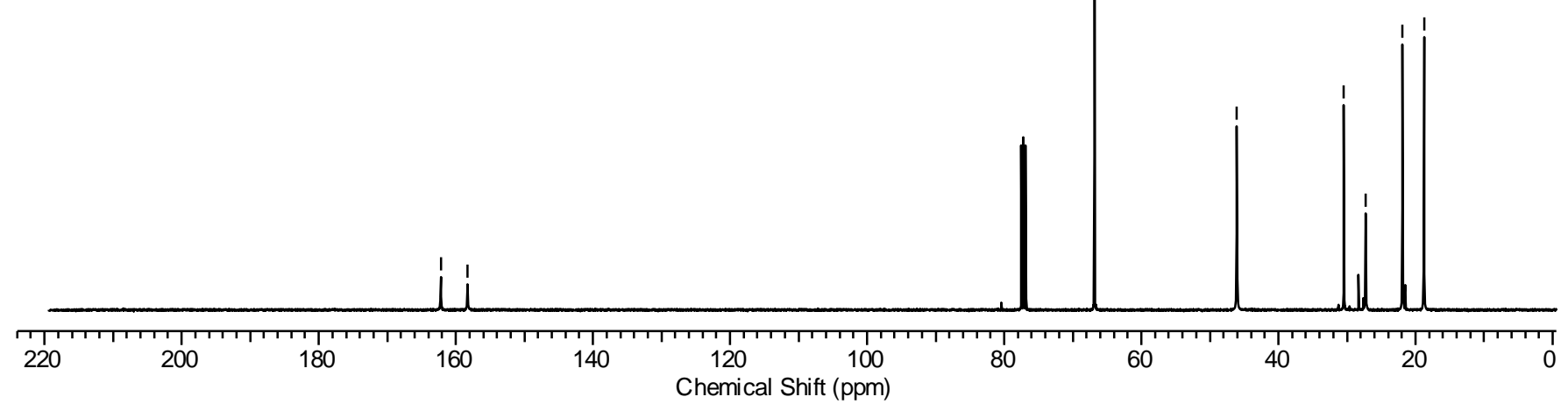


<smiles>CC(C)C(=NNC(=O)NC(C)(C)C)C(C)C</smiles>

$1 c$

Table 2, 7, 10

$\int \quad 5$

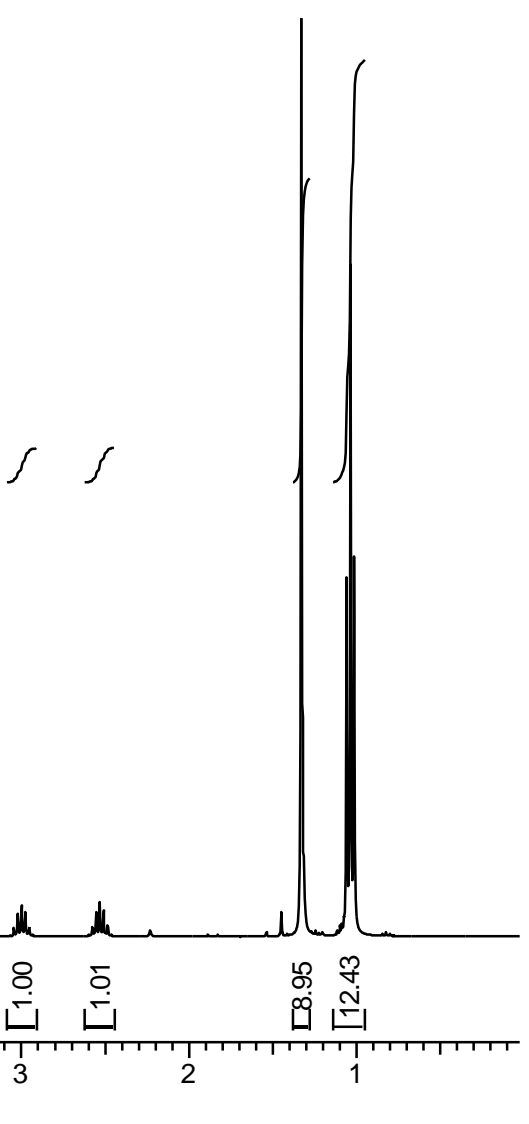

ஐ

잉

广

Chemical Shift (ppm)

कू.
Chemical Shift (ppm)

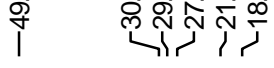

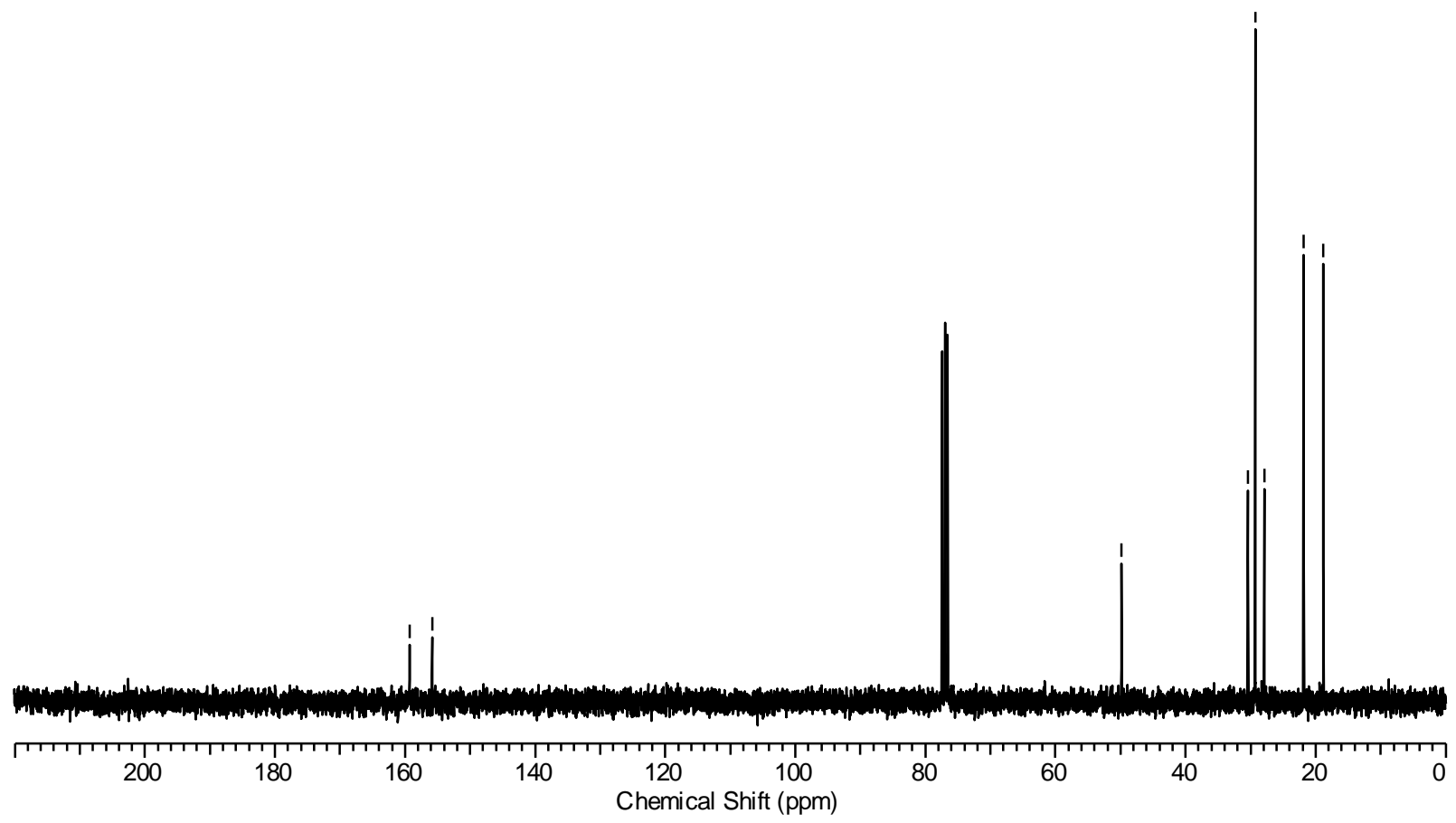




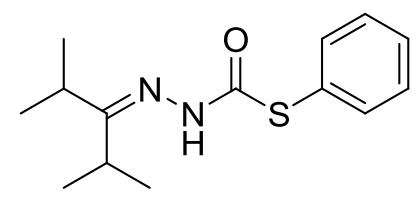

1b

Table 3, 4, 7, 10

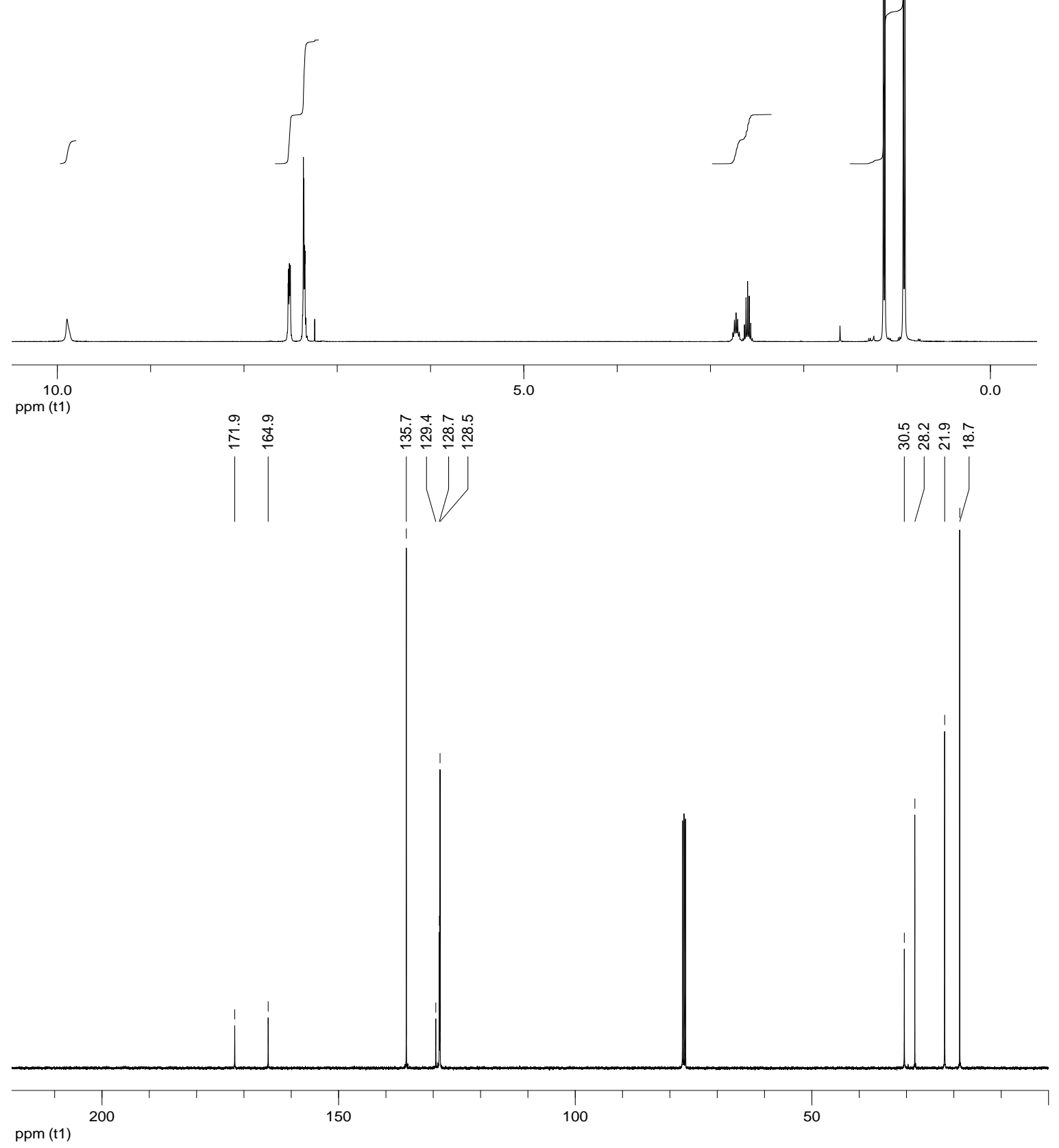




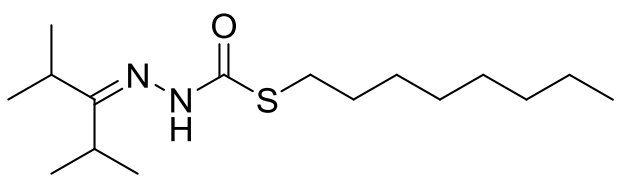

1h

Table 7, 10
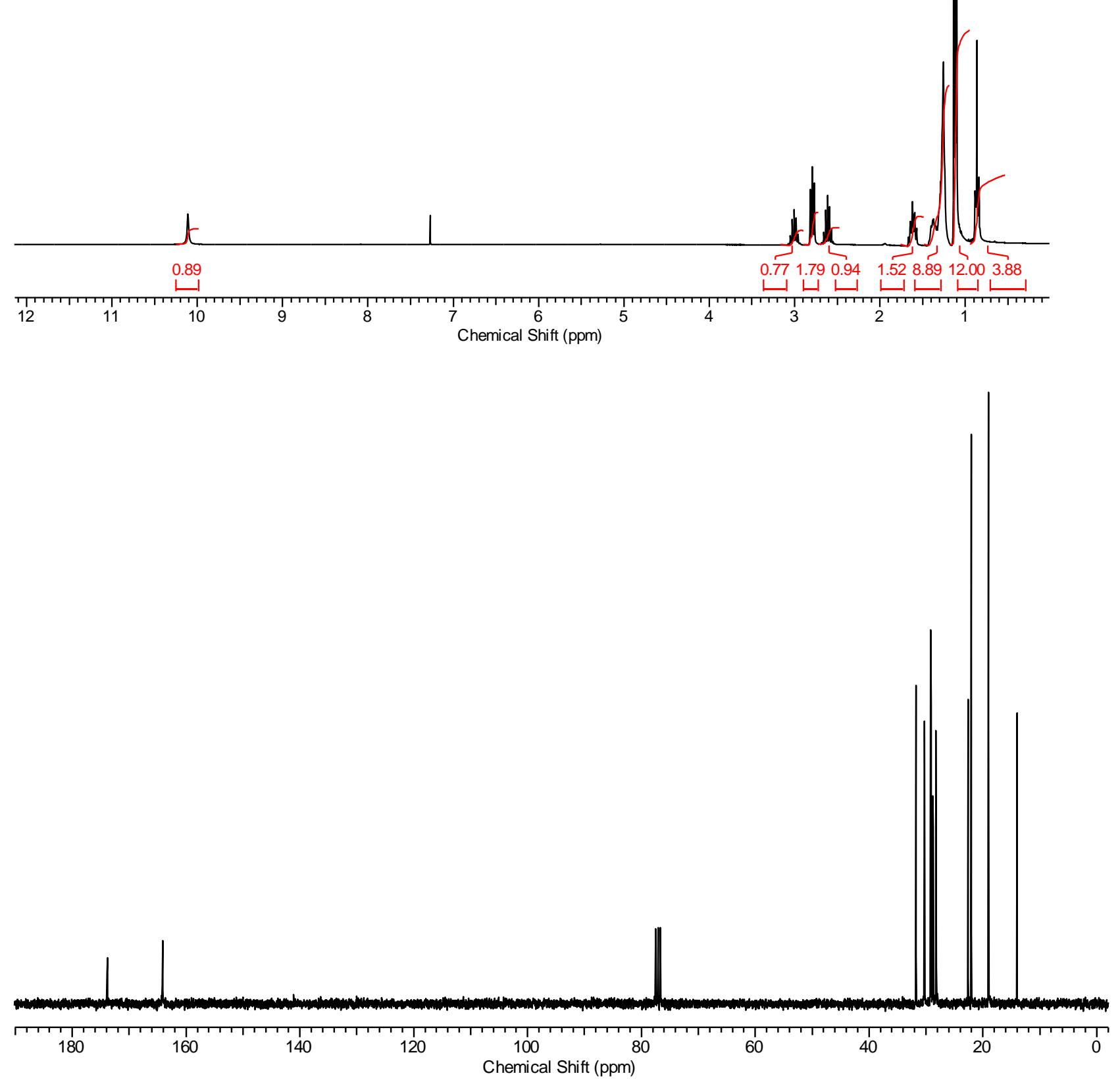
<smiles>CC(C)NC(=O)NN=C(C(C)C)C(C)C</smiles>

1i

Table 7
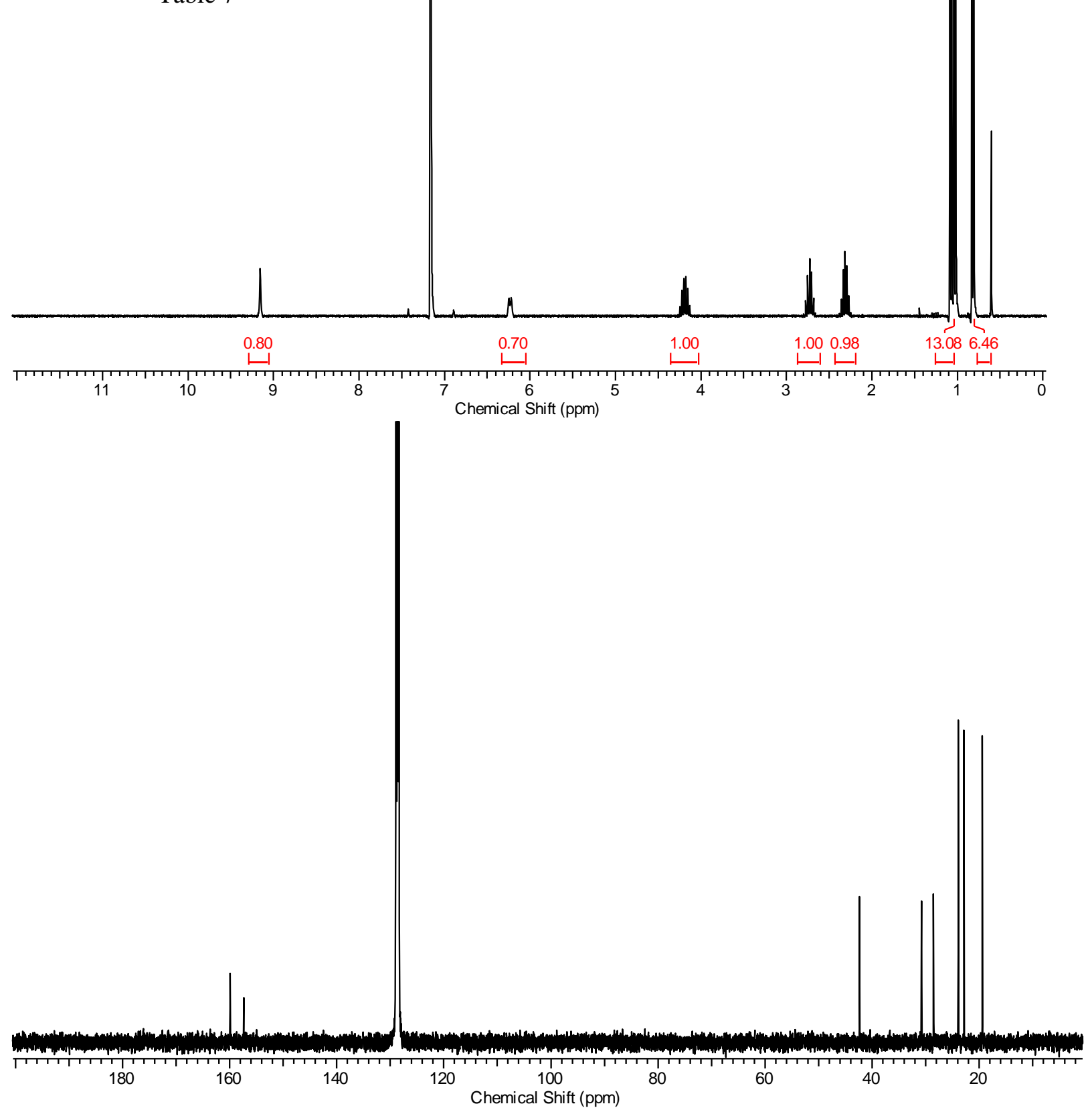


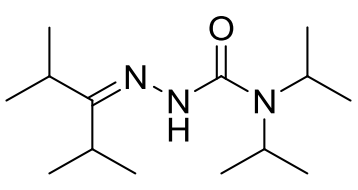

1f

Table 7, 10

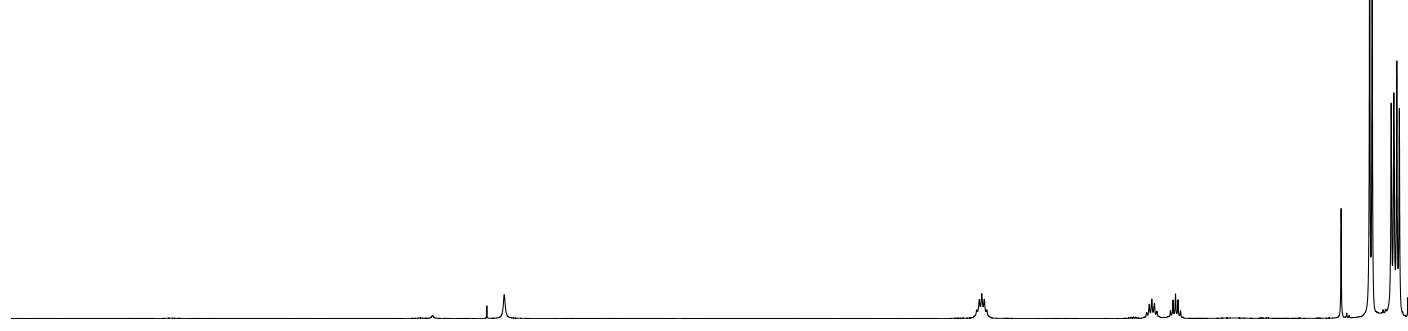

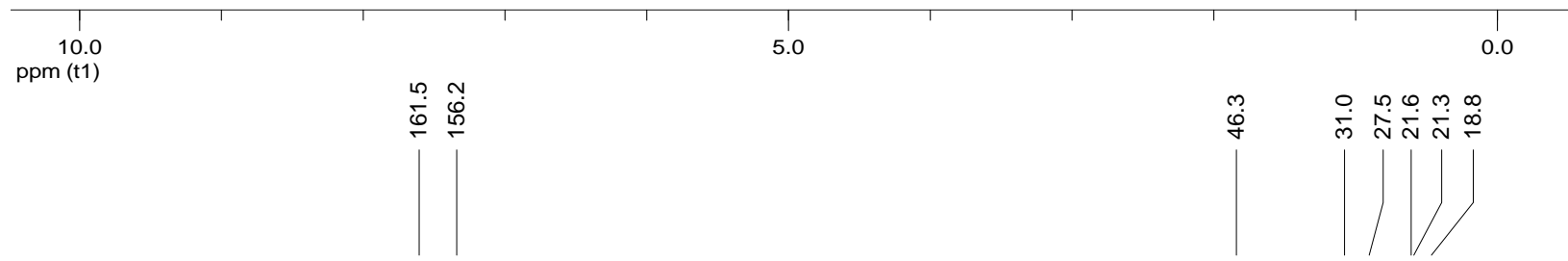

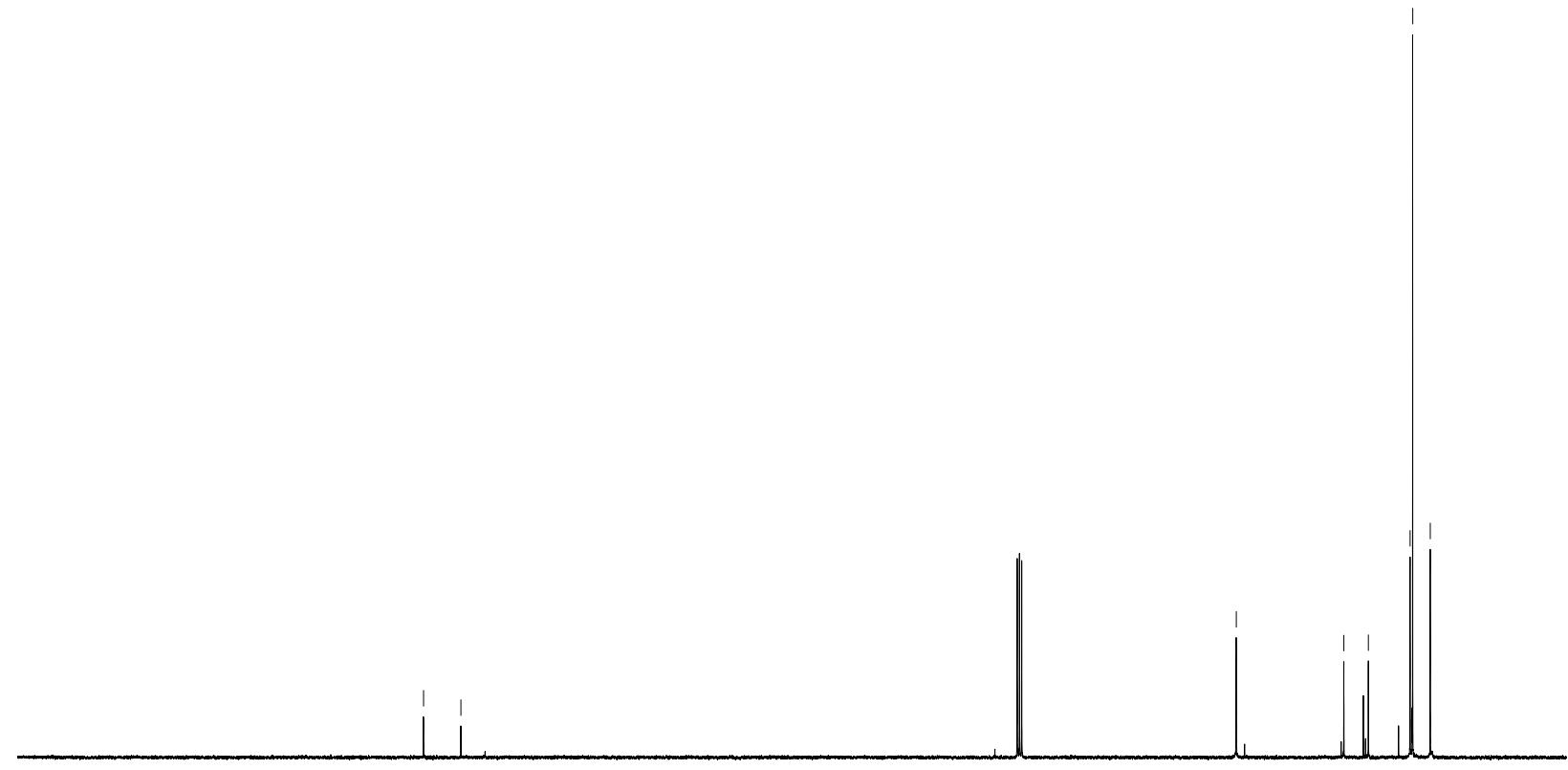

200

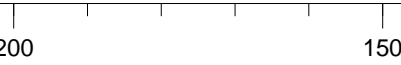

150

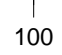

50

ppm (t1) 


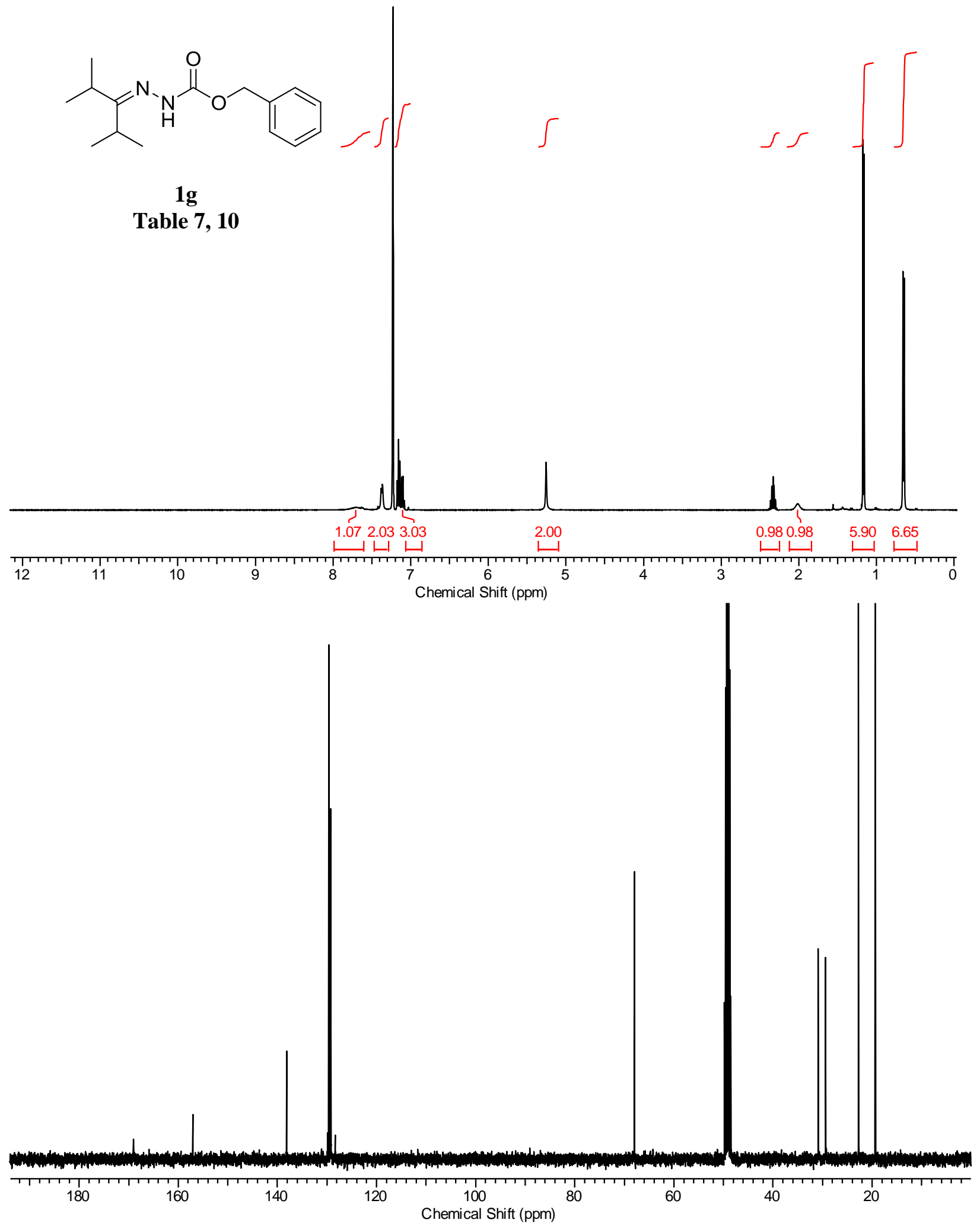

S92 
<smiles>CC(C)C(=NNC(=O)Oc1ccccc1)C(C)C</smiles>

1i

Table 1 substrate, Table 7

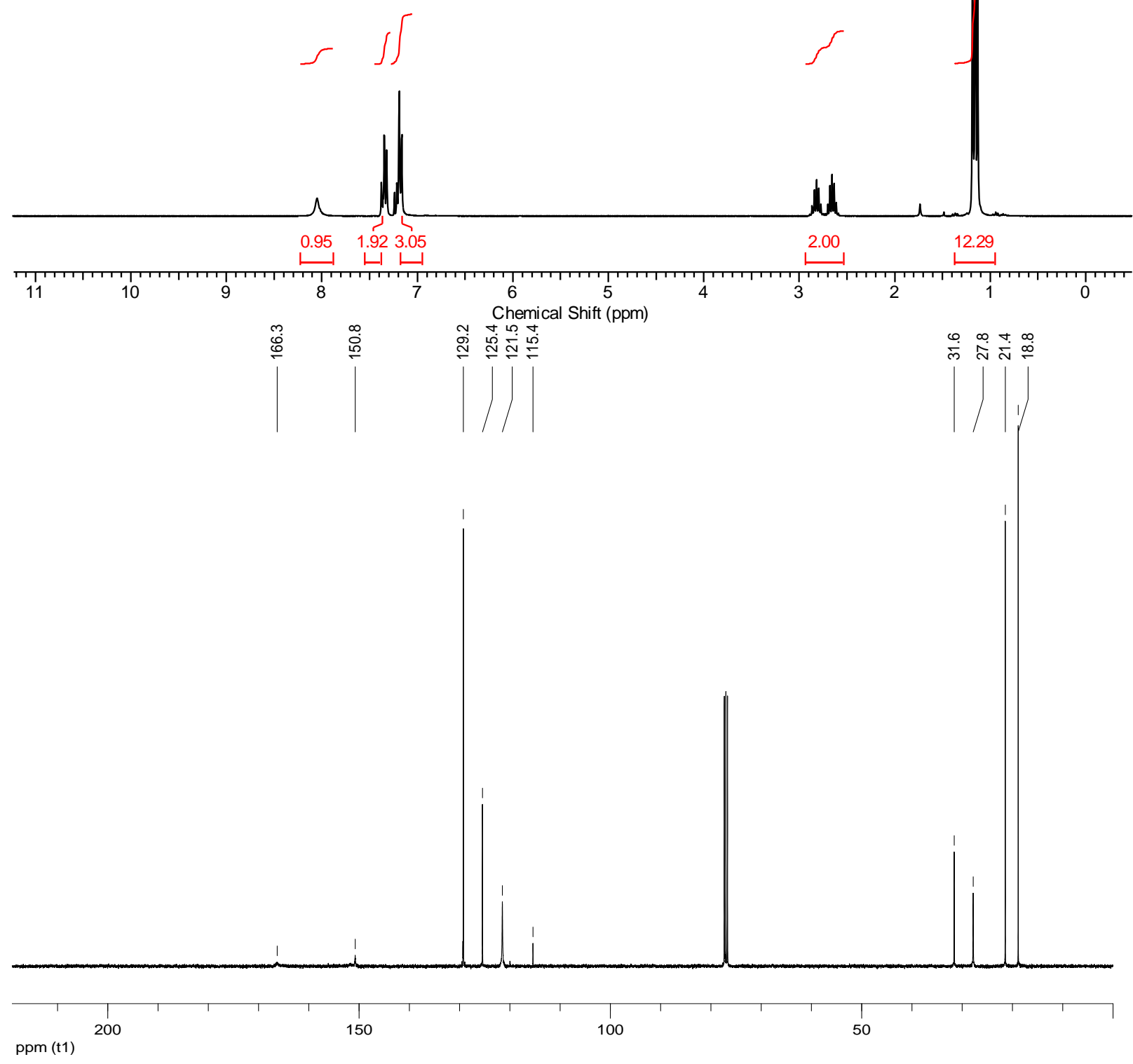




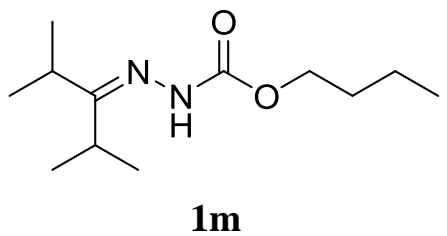

Table 9
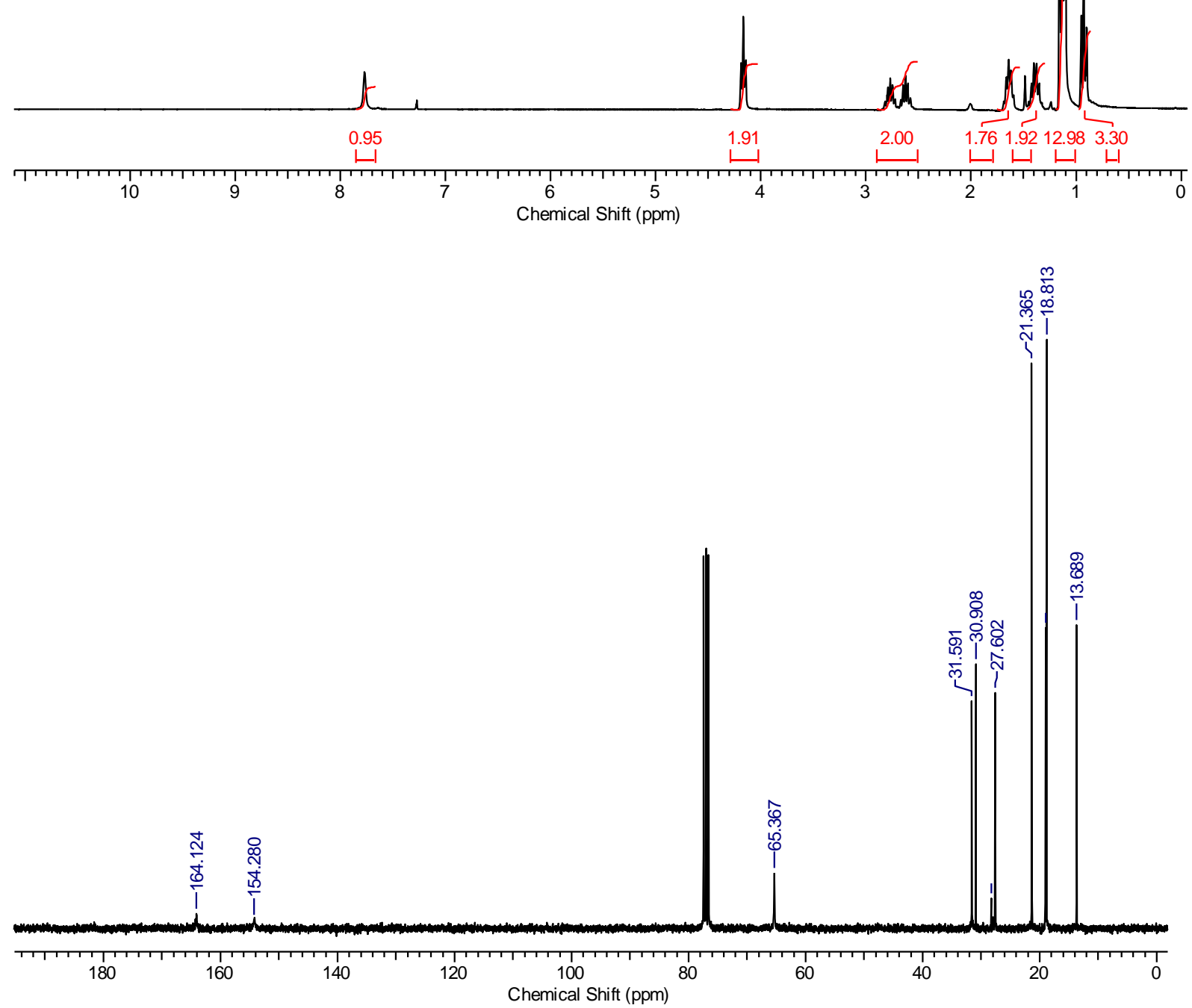

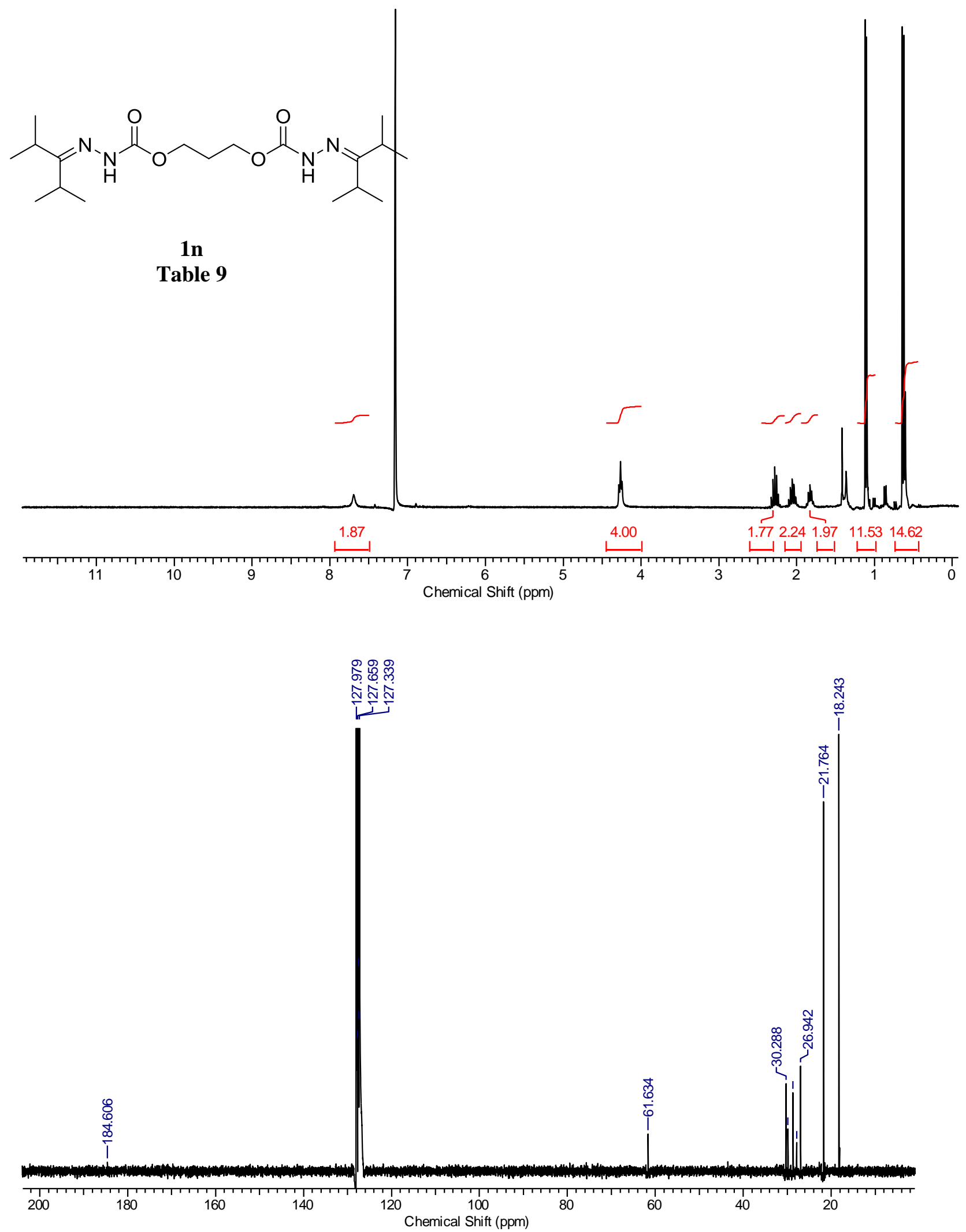
<smiles>C=CCCC/C=N/NC(=O)NC(C)C</smiles>

2b

Table 11
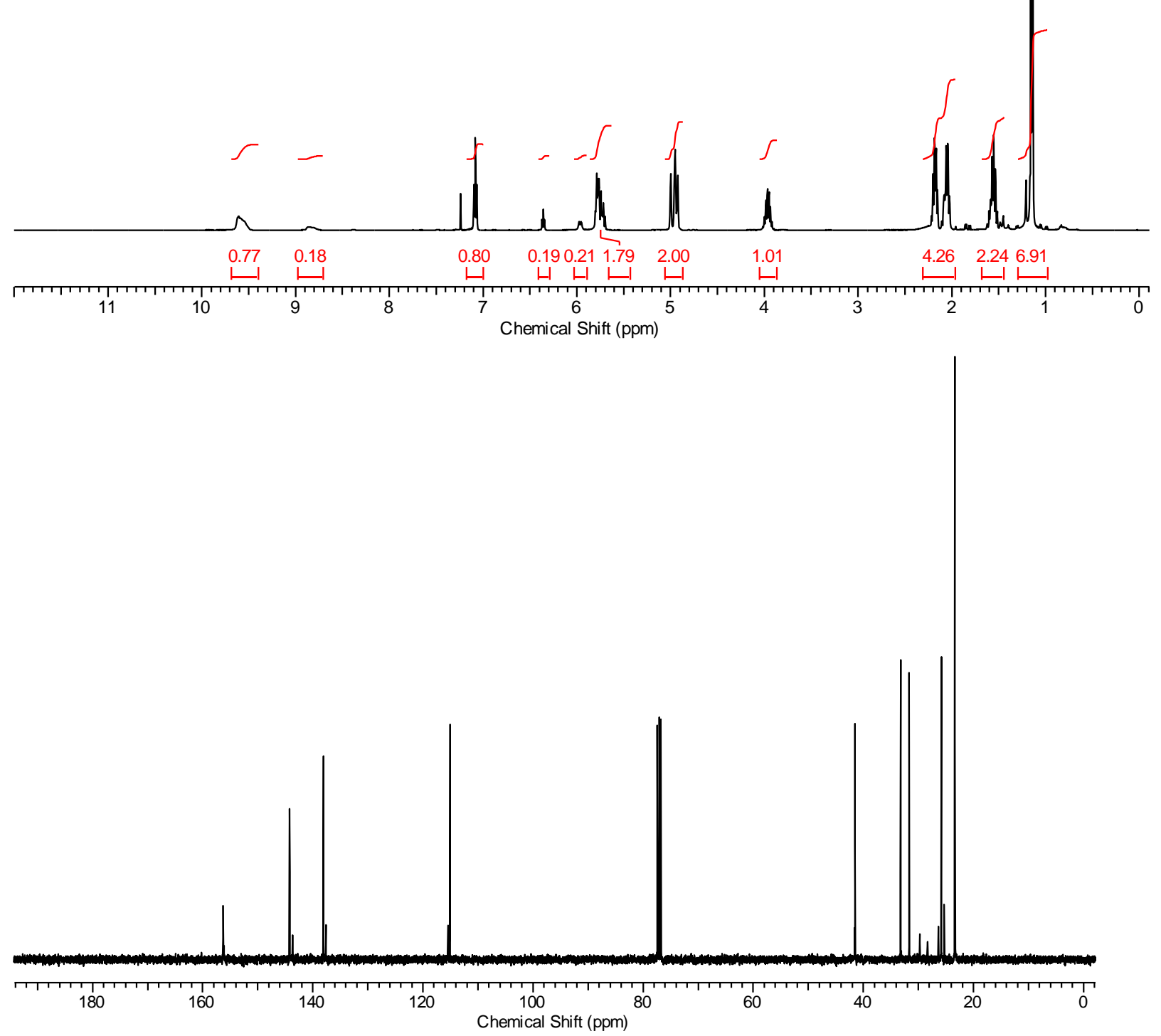


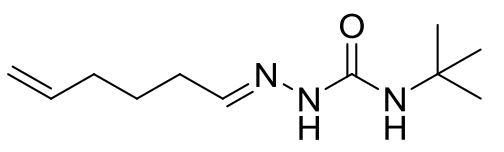

2c

Table 11
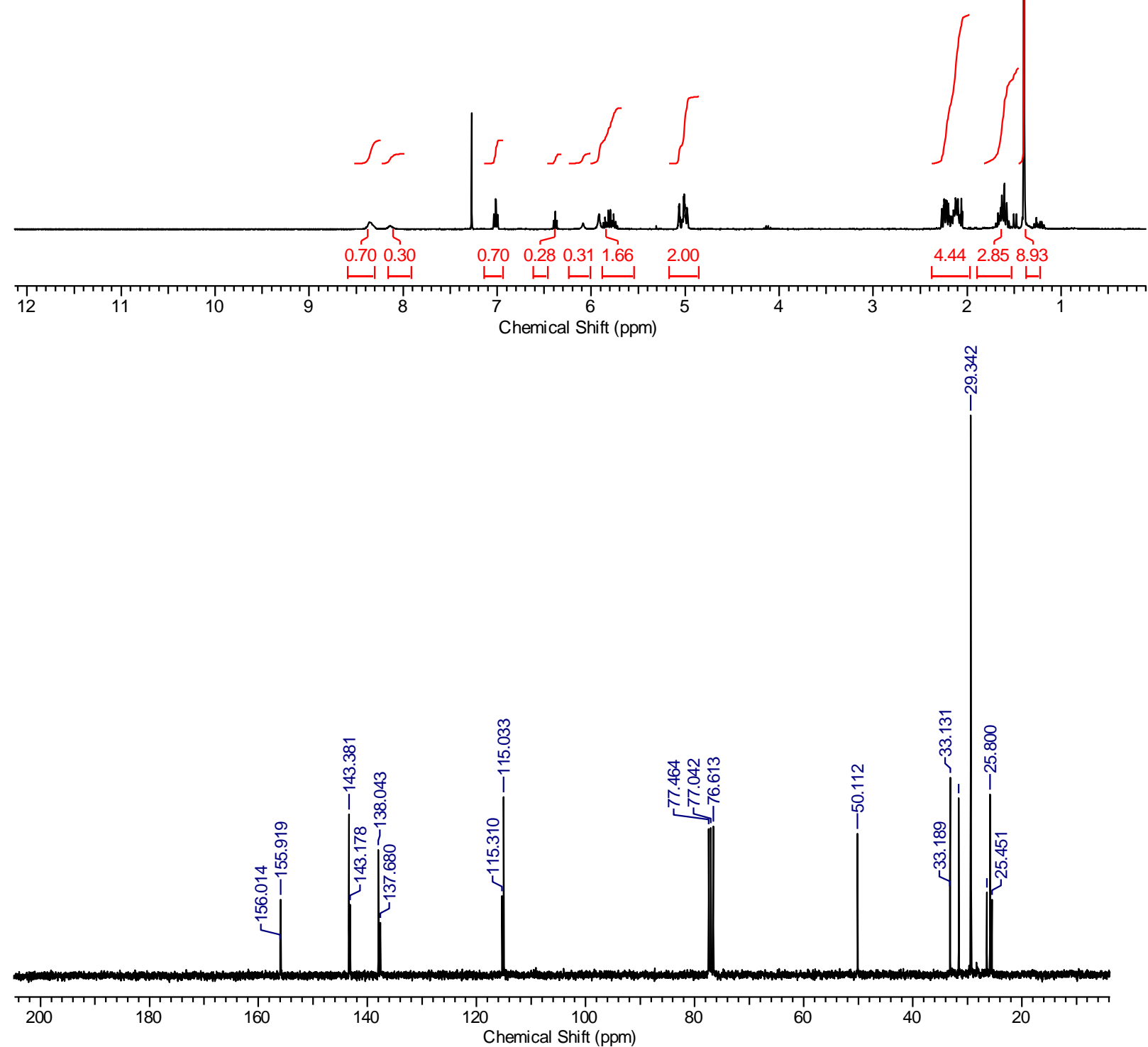
<smiles>C=CCCC/C=N/NC(=O)Nc1ccccc1</smiles>

2d

Table 11
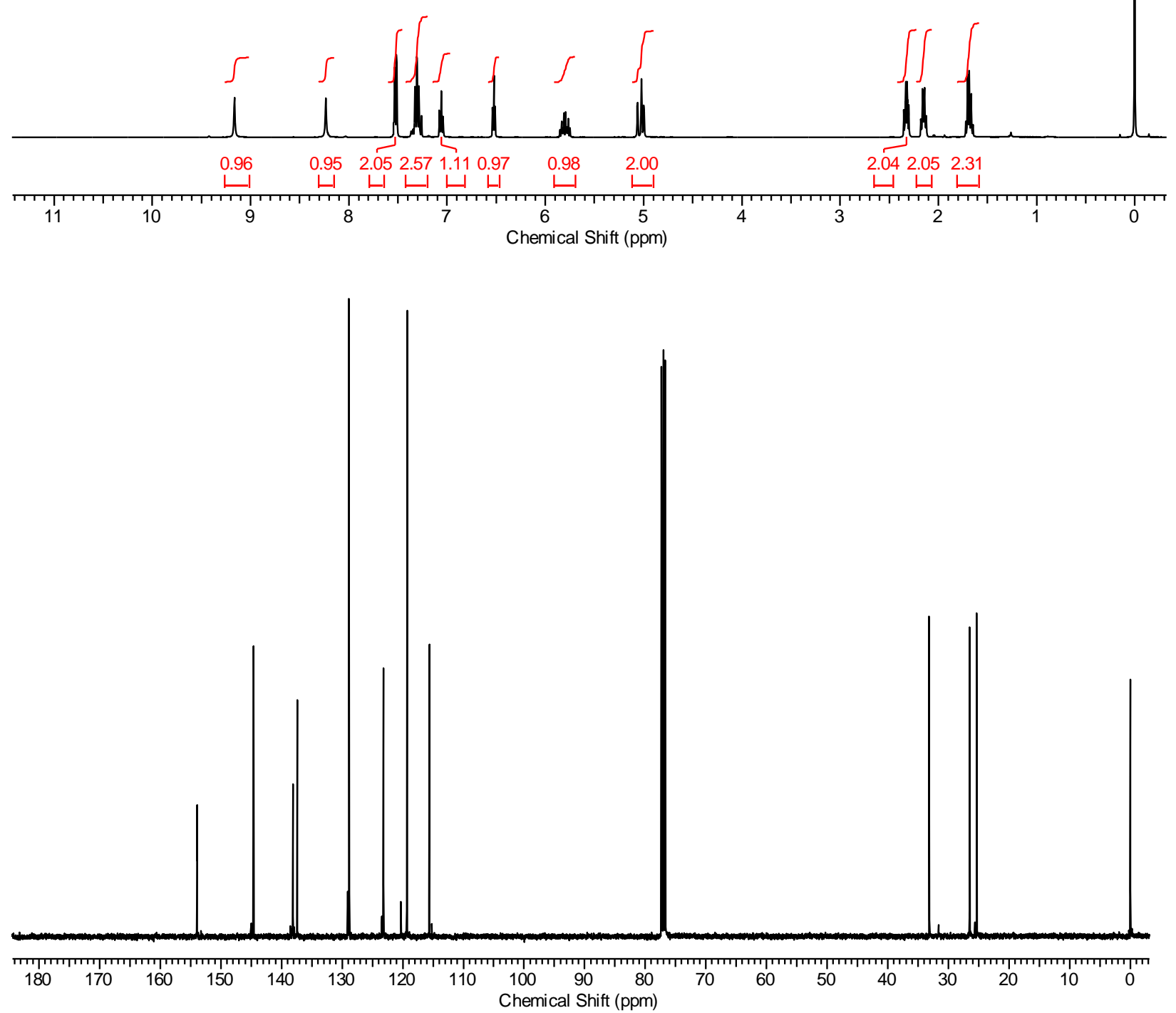
<smiles>C=CCCC/C=N/NC(=O)Sc1ccccc1</smiles>

$2 \mathrm{e}$

Table 11
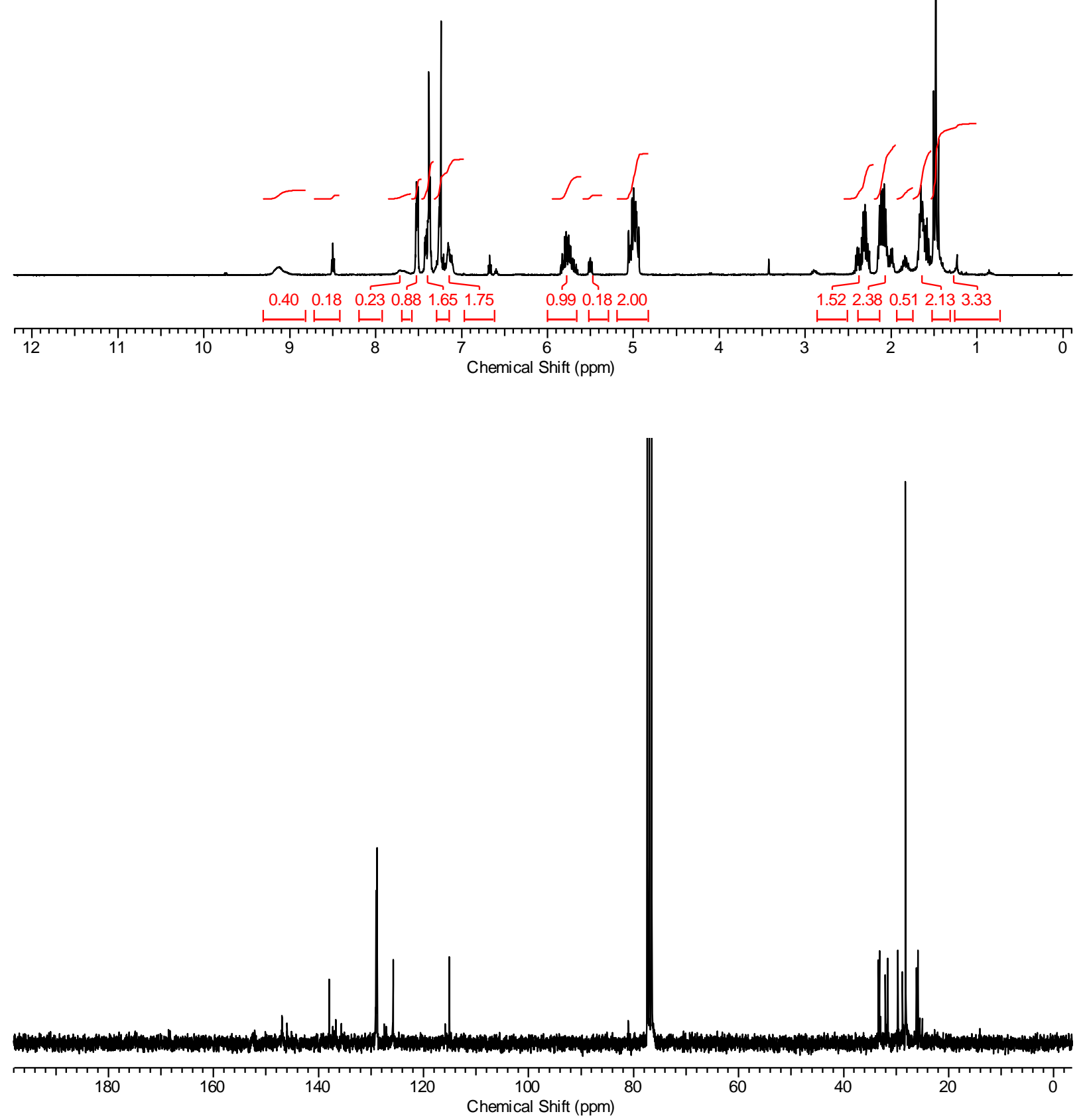

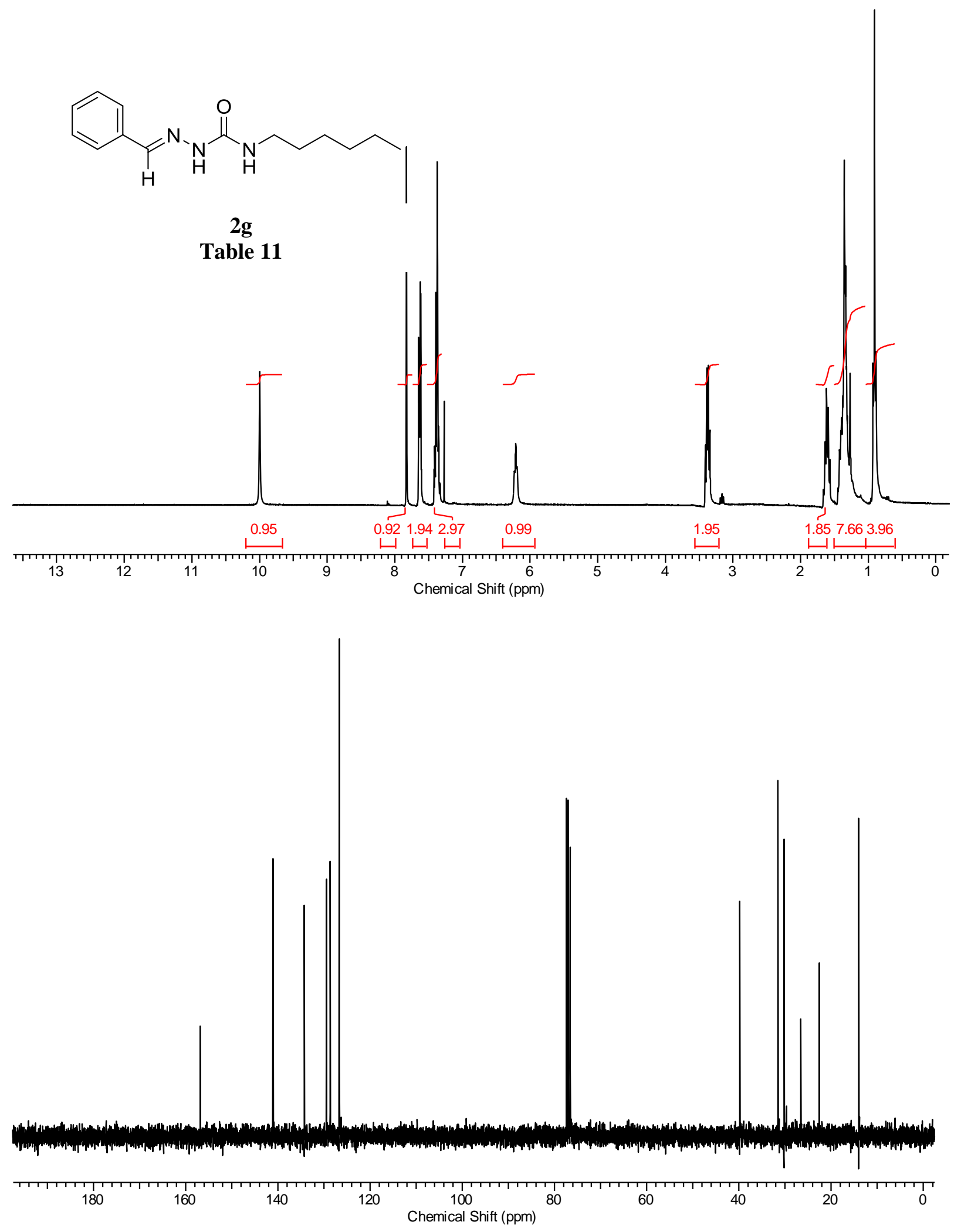

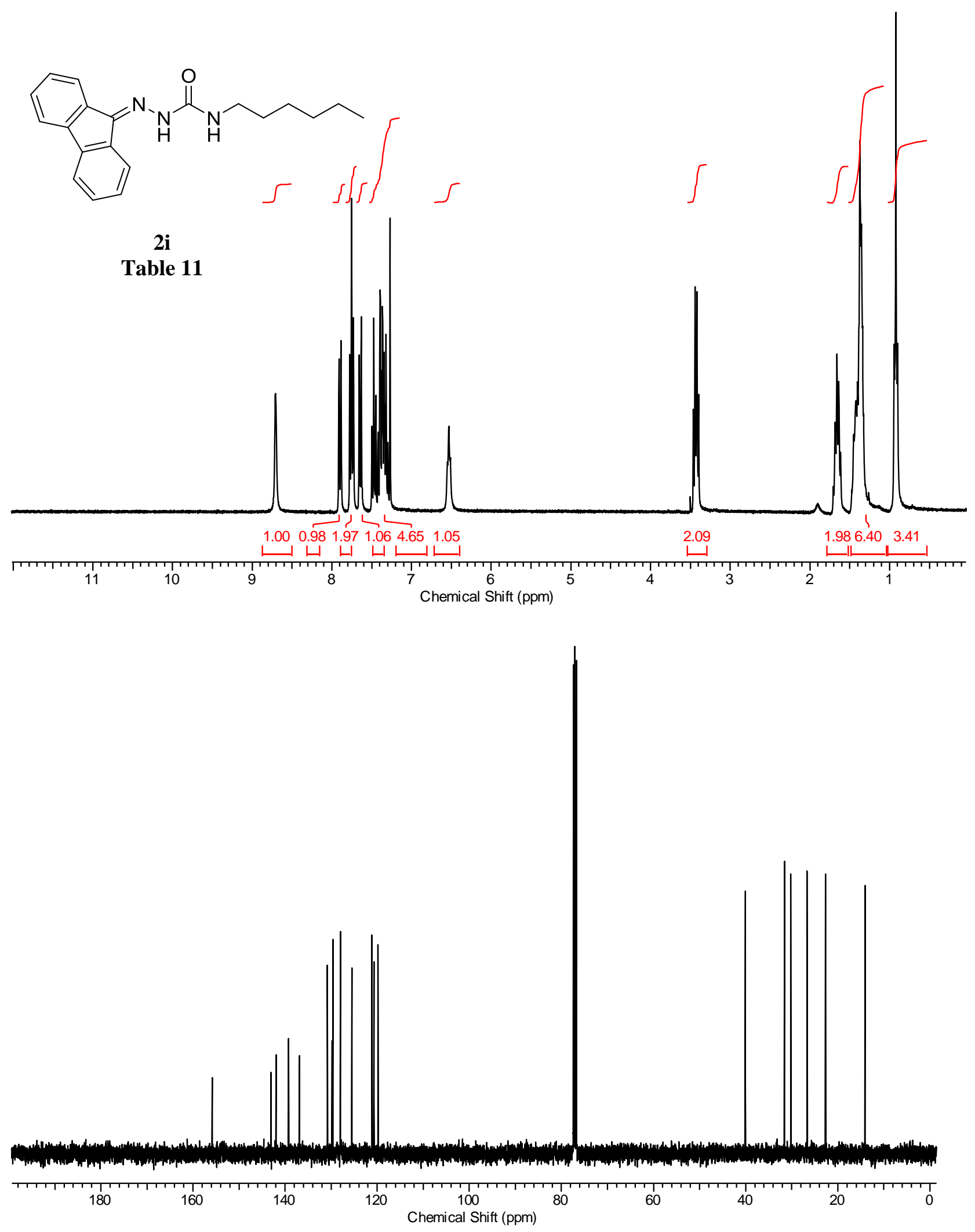

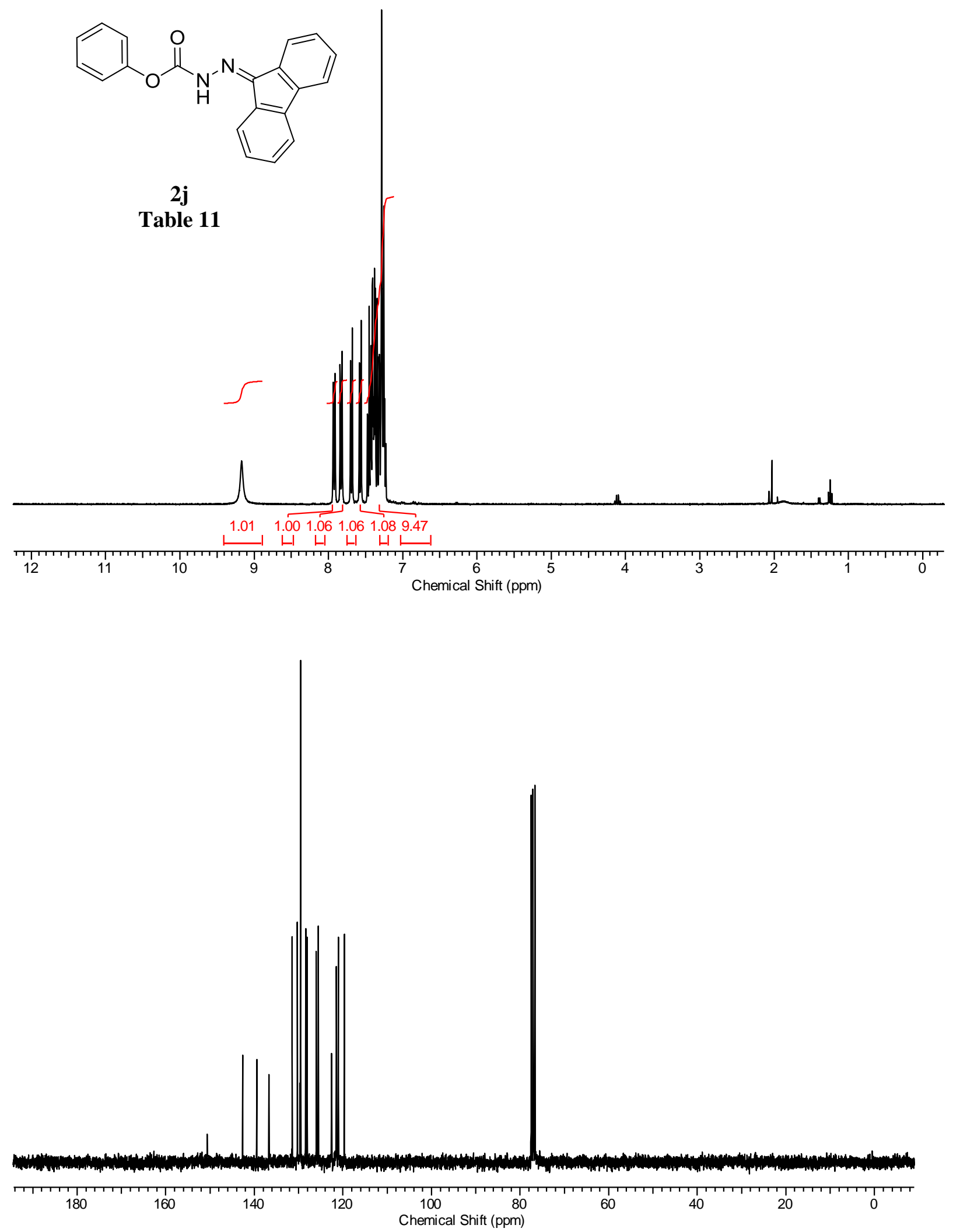
<smiles>C=CCC/C(C)=N/NC(=O)NCCCCCC</smiles>

$4 a$

Figure 23
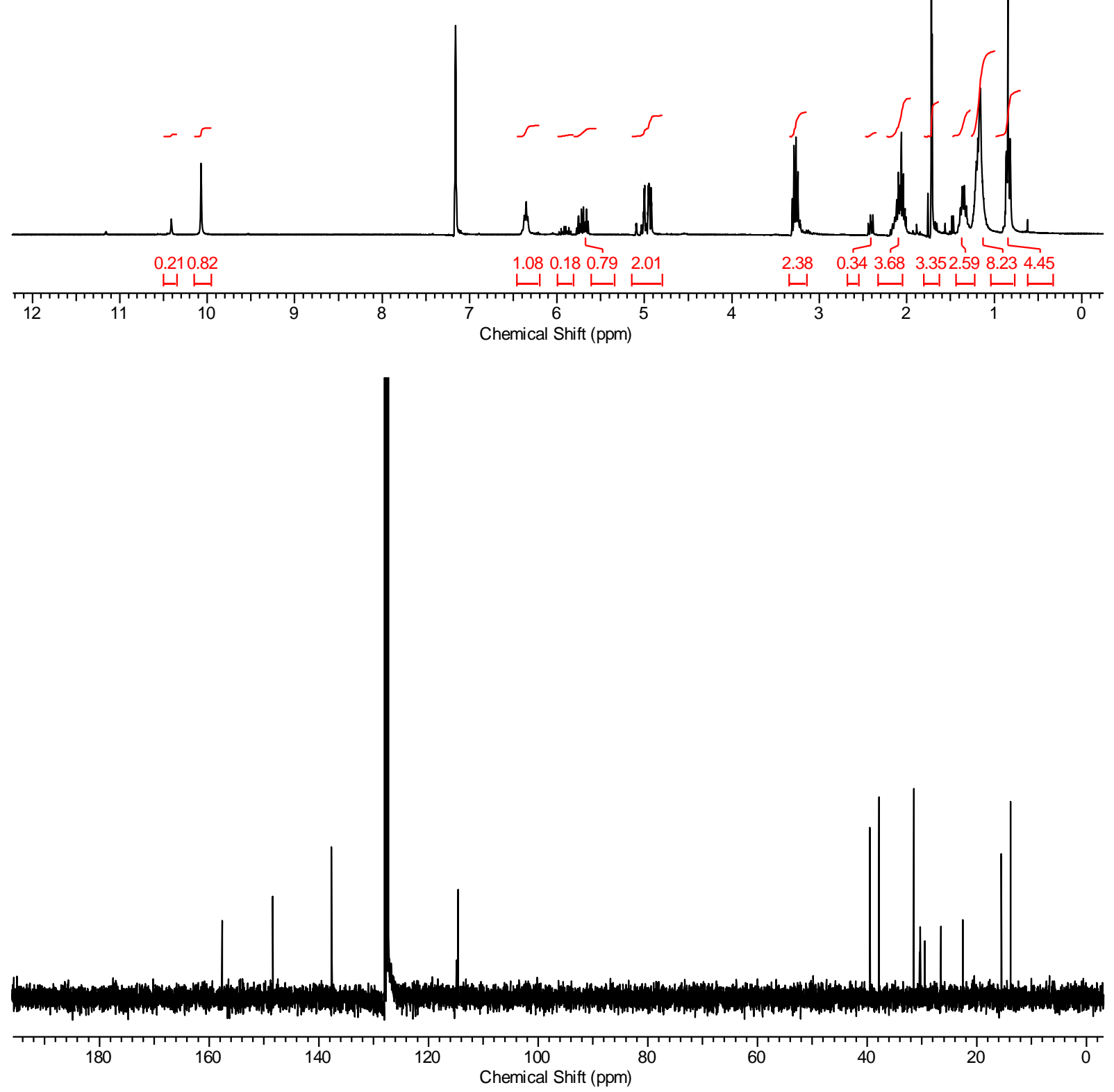

S103 
<smiles>CCN(CC)C(=O)NN=C(C(C)C)C(C)C</smiles>

4b
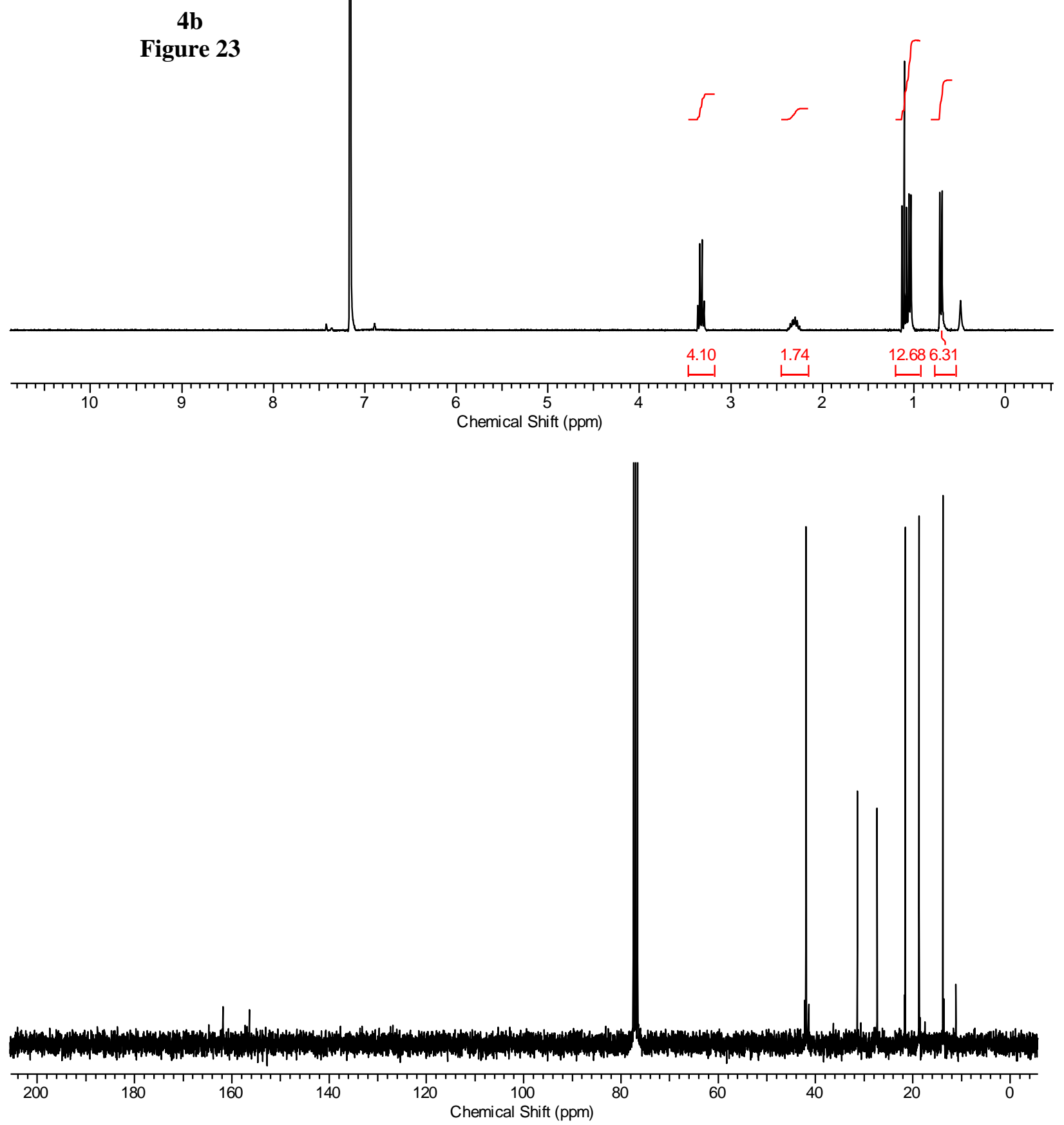

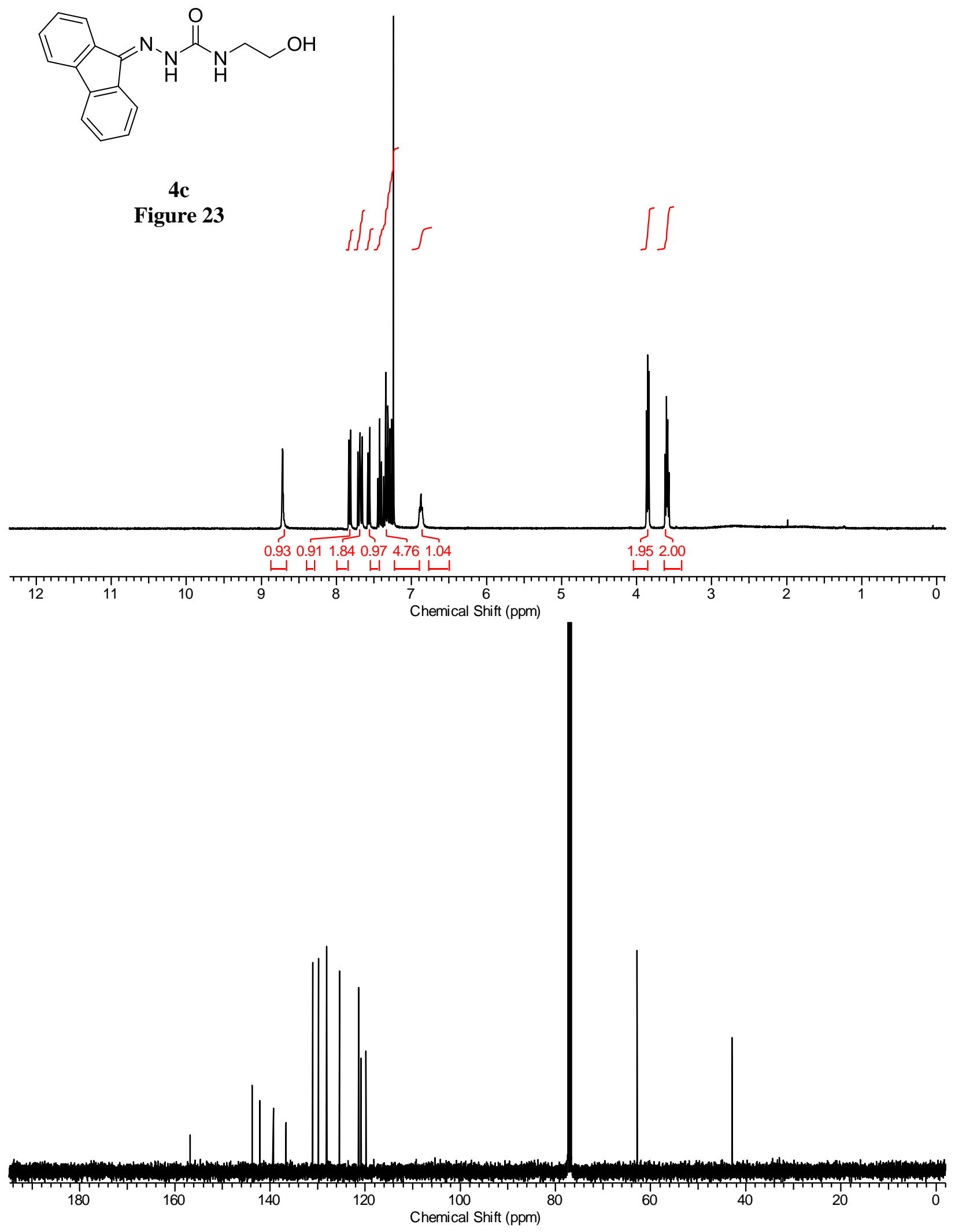

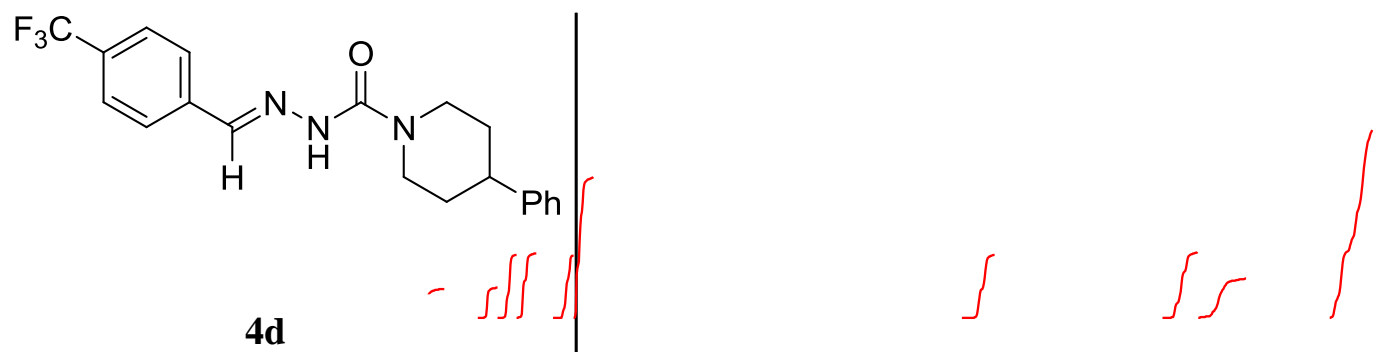

Figure 23
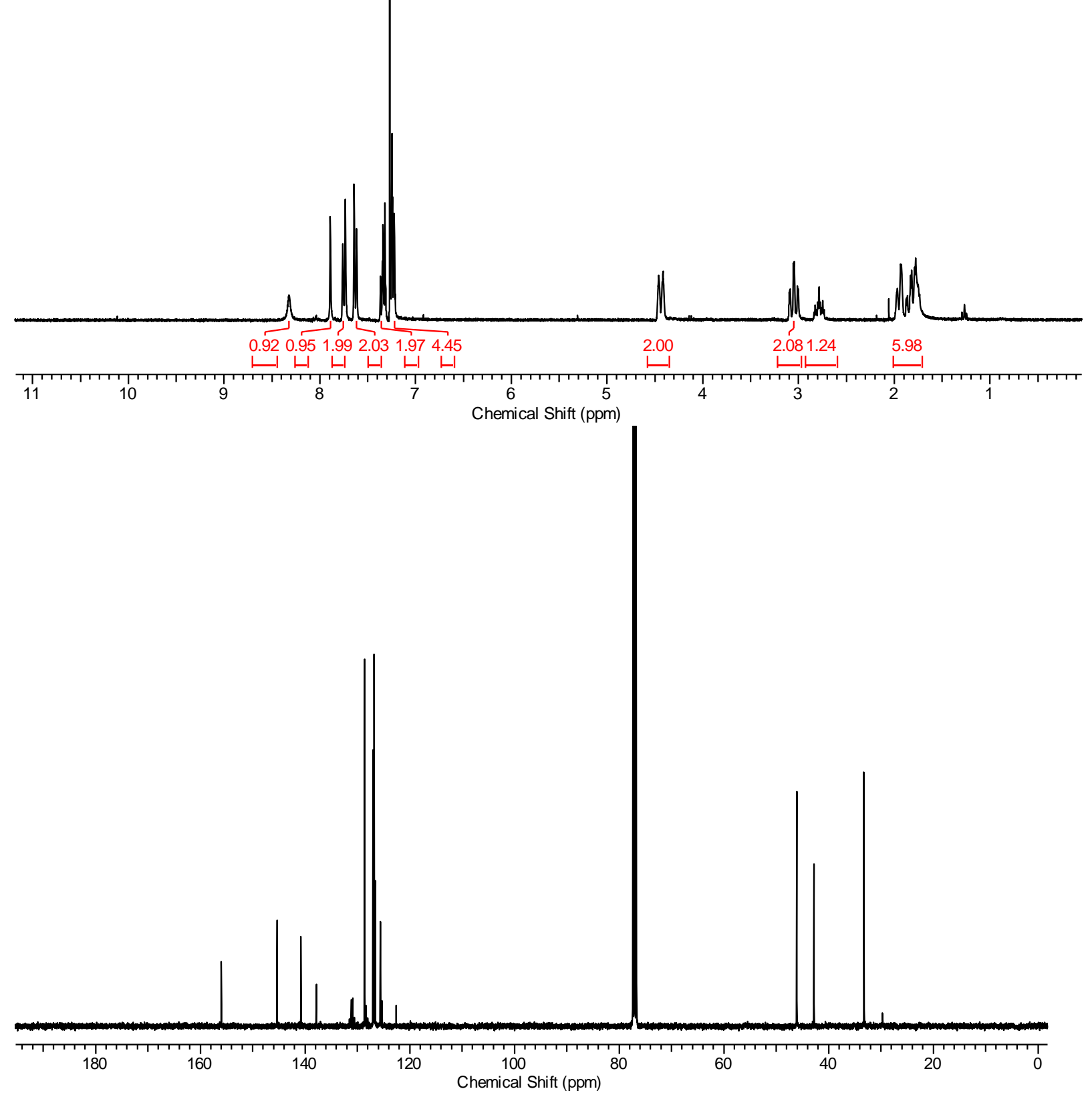

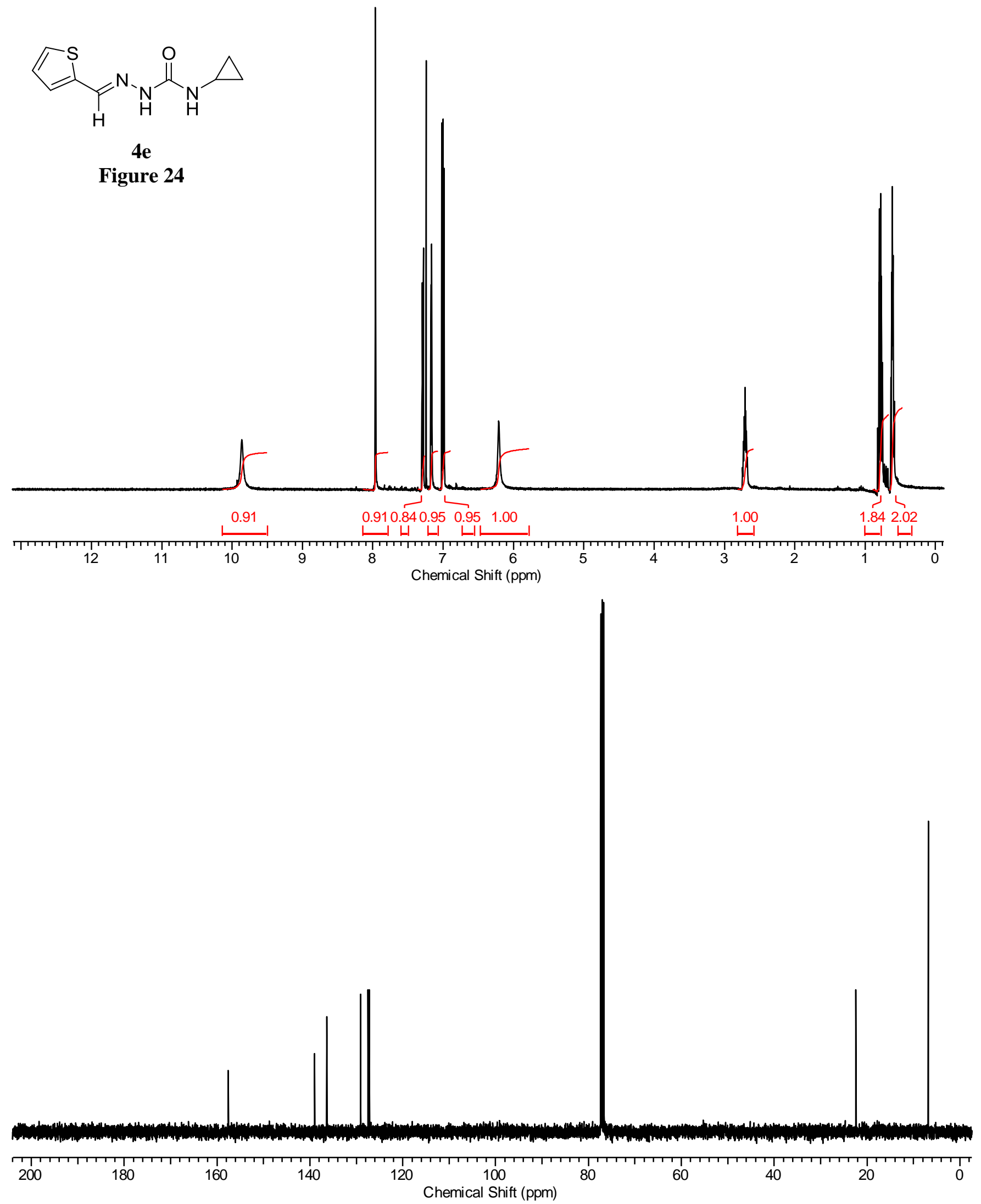


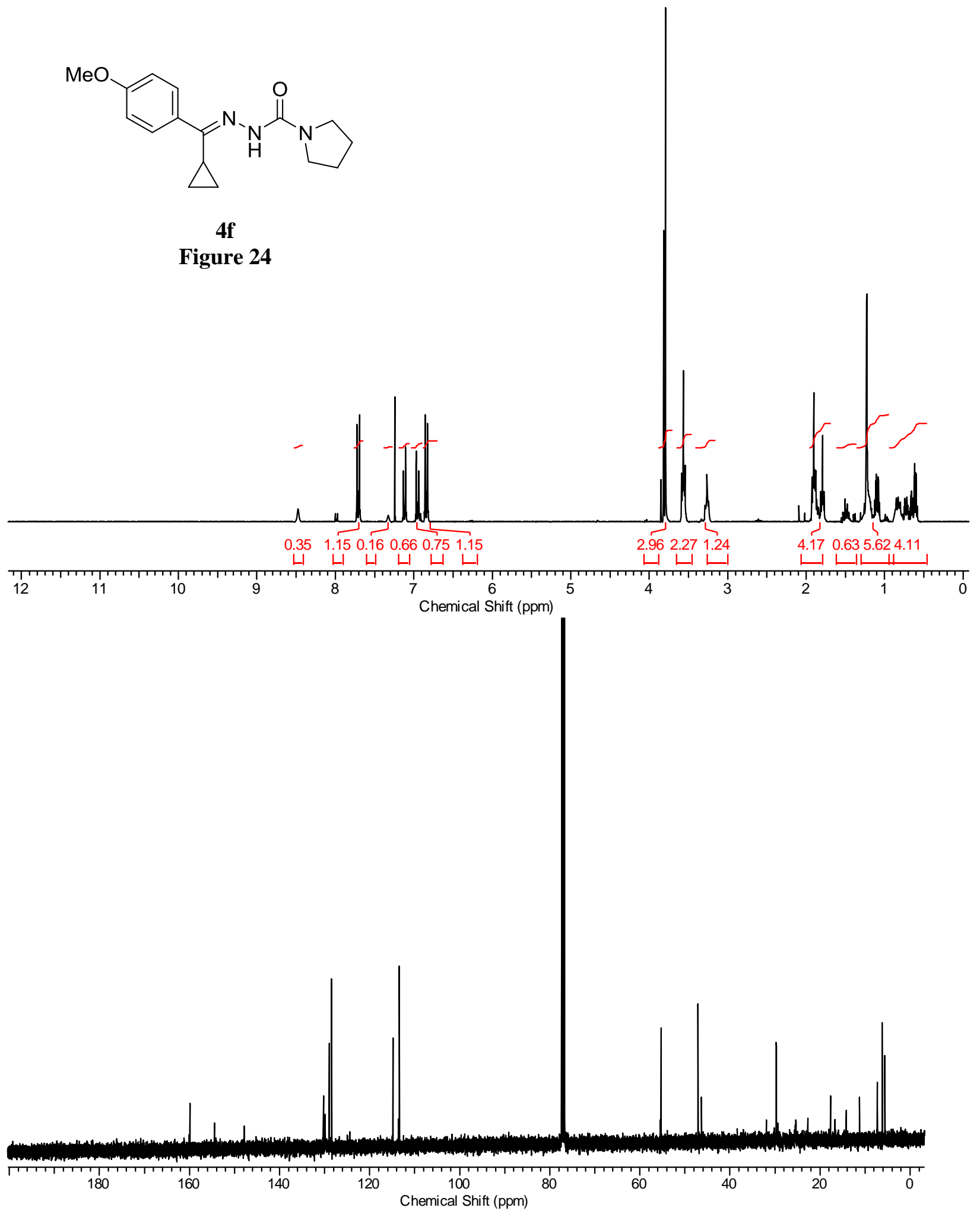

S108 


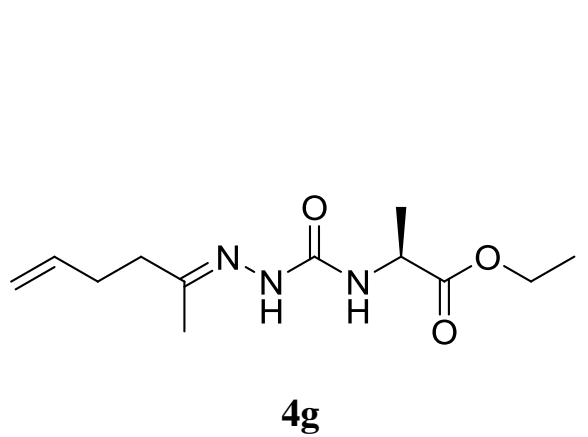

Figure 24
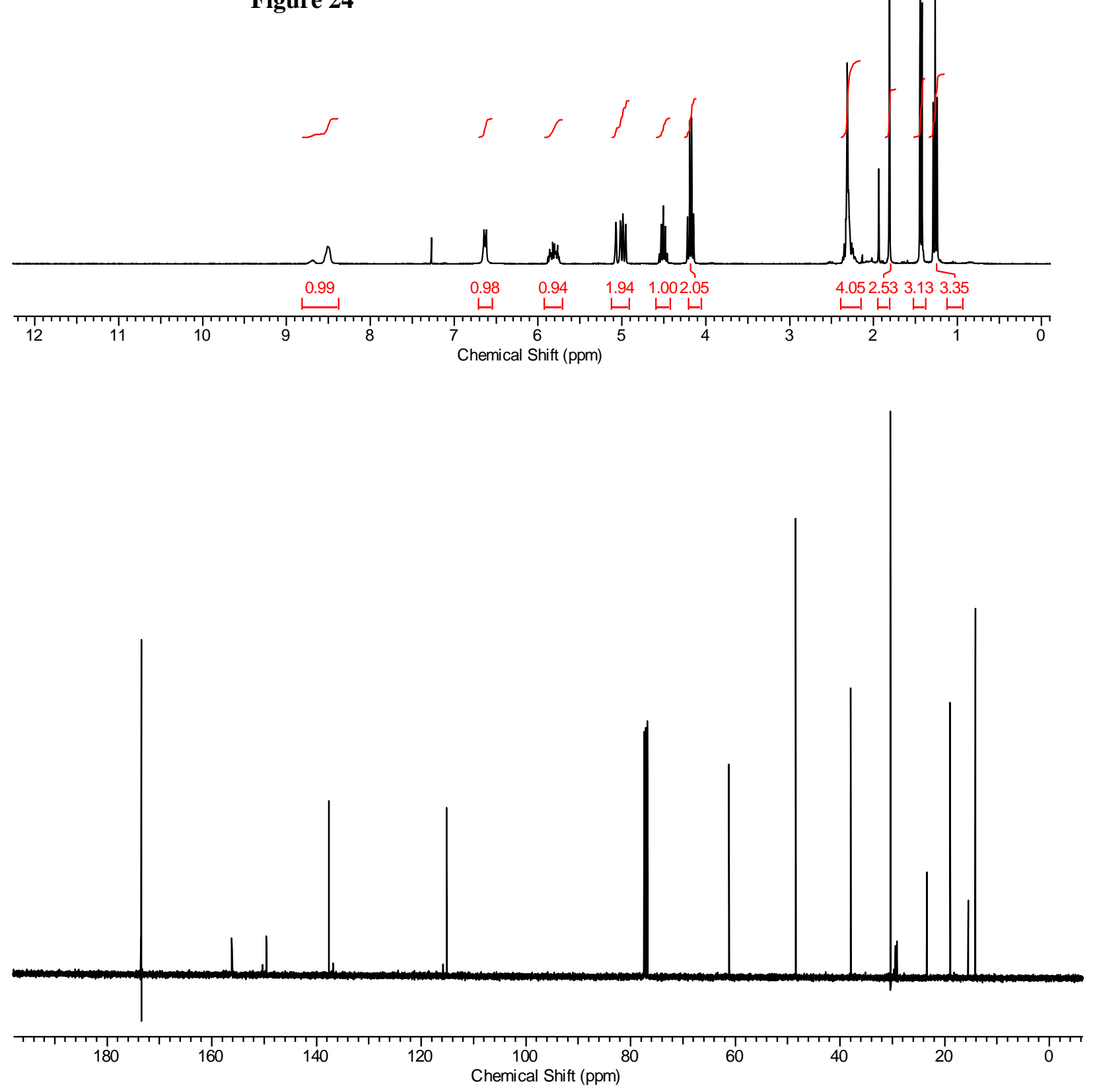


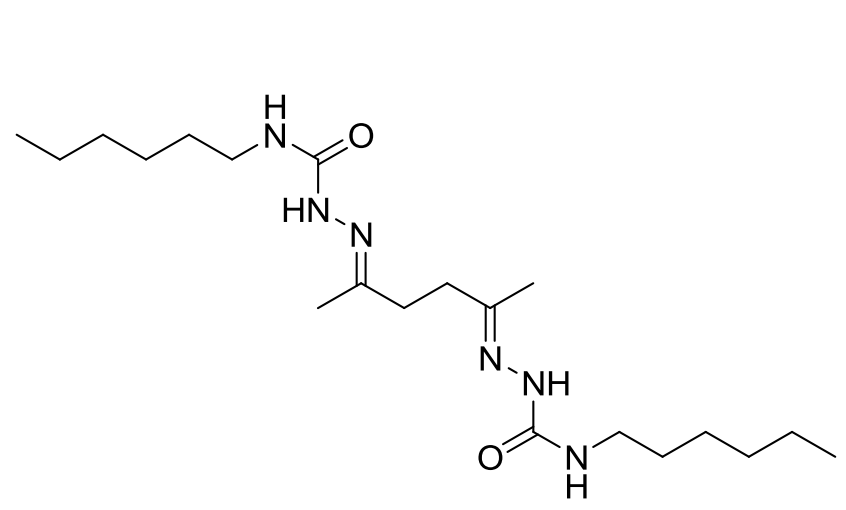

$5 c$

Eq 16
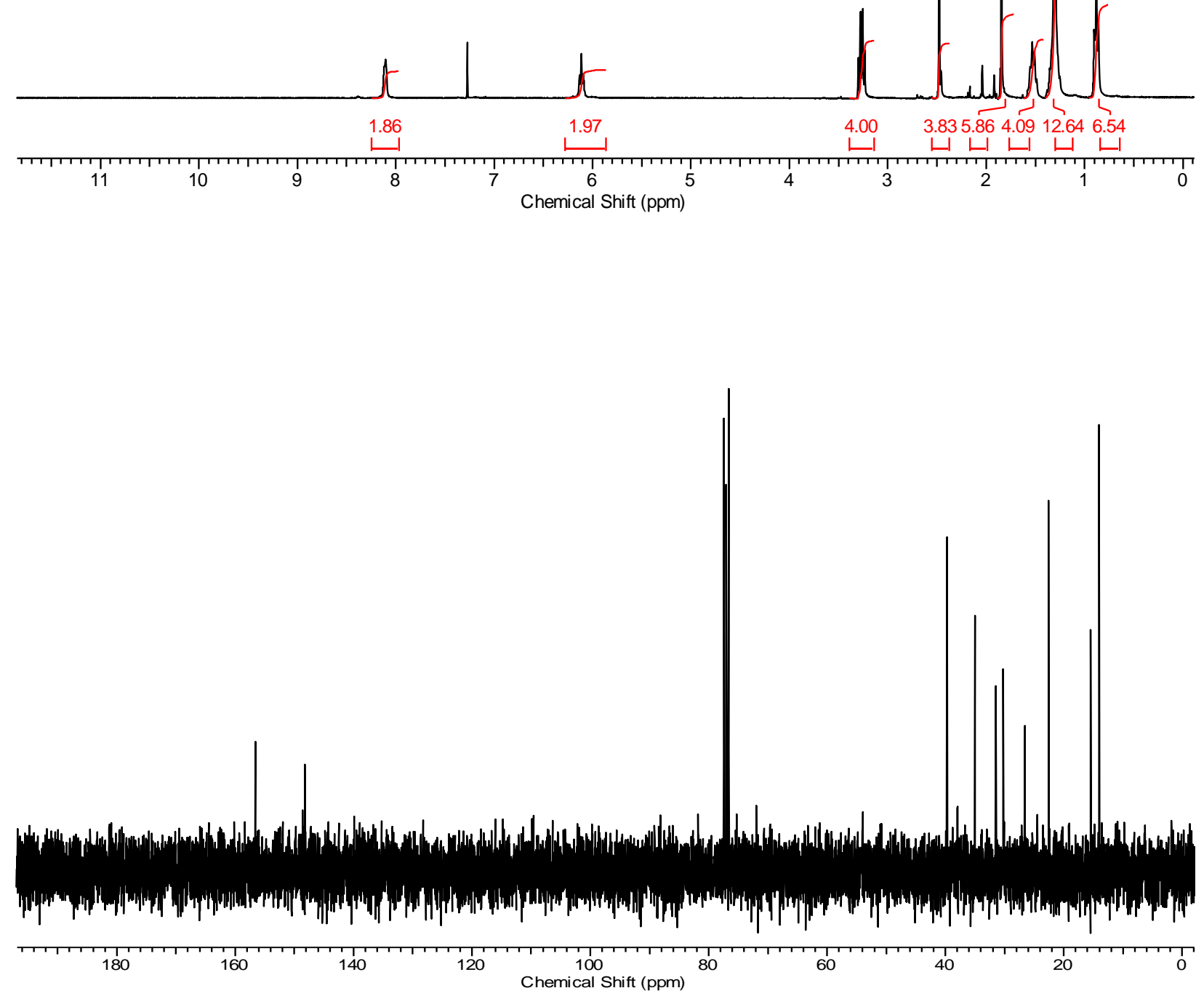


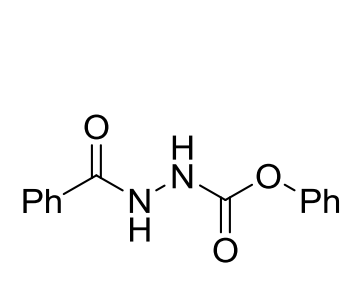

$6 a$

Table 12
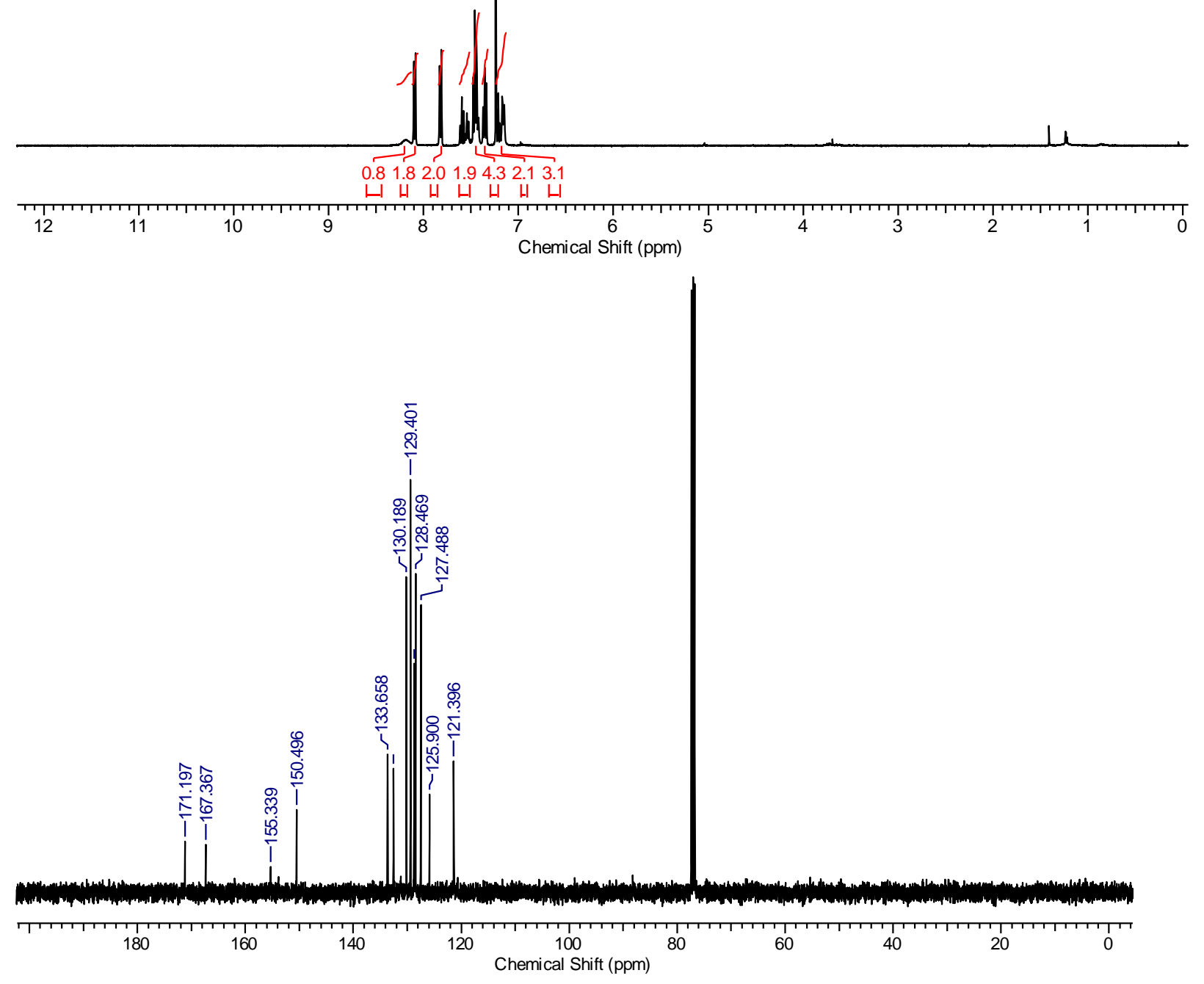


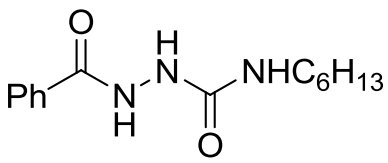

6b

Table 12
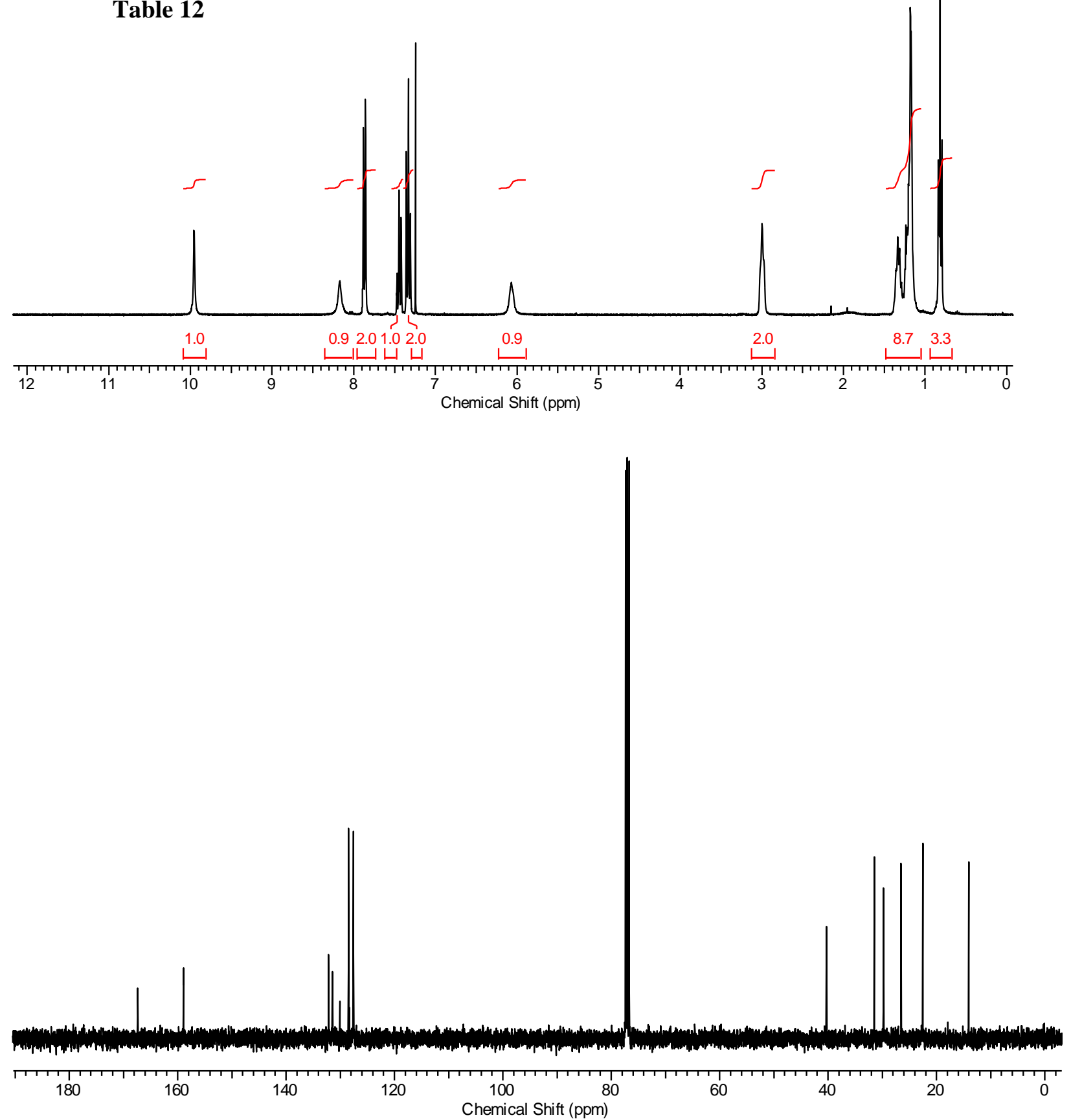
<smiles>CCN(CC)C(=O)NNC(=O)c1ccccc1</smiles>

6c

Eq 17
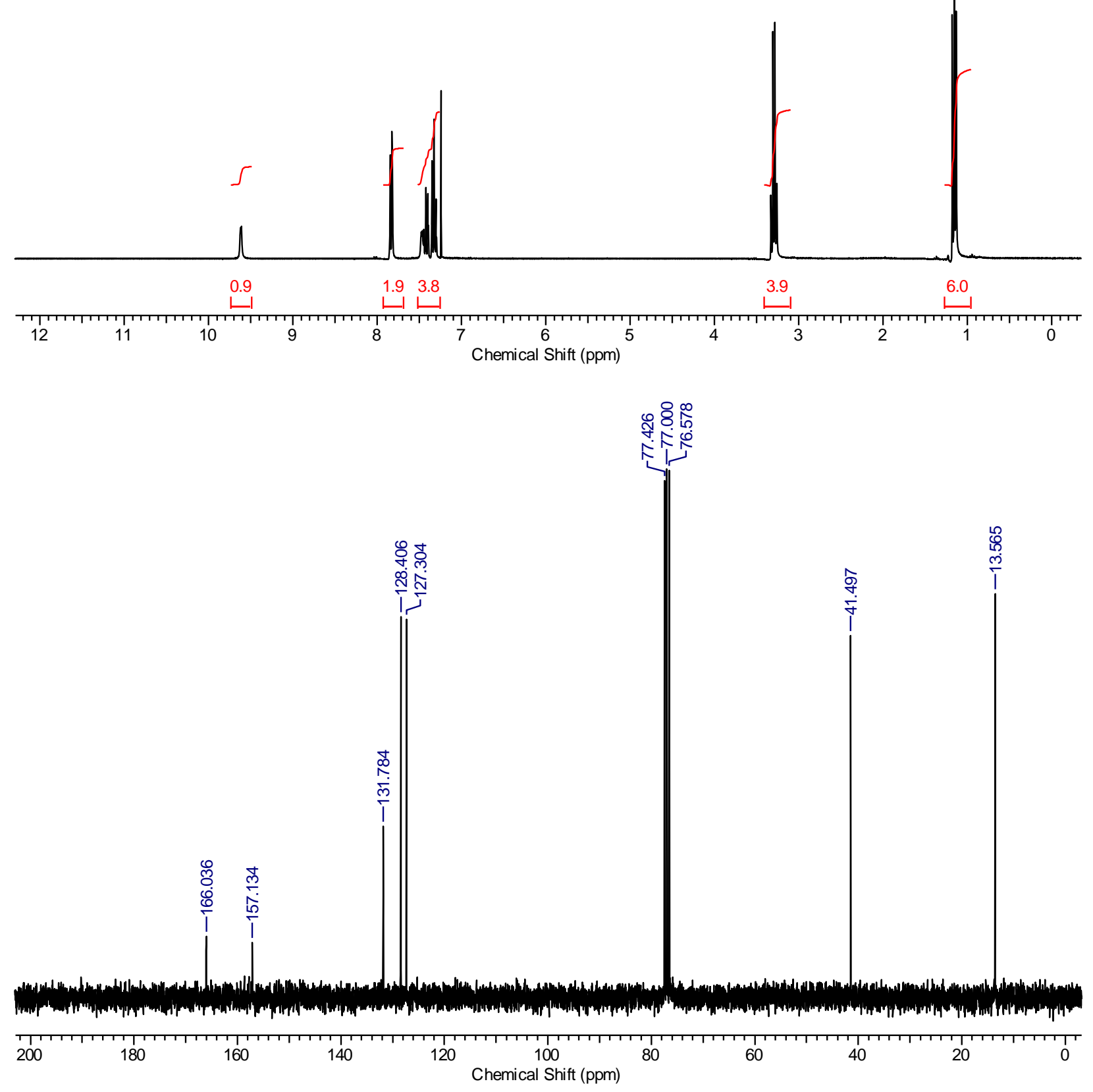


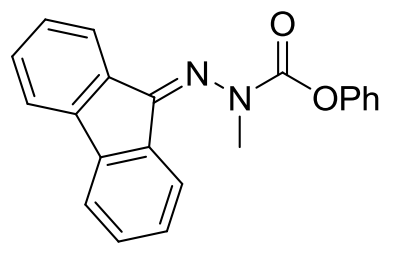

$7 a$

Eq 19
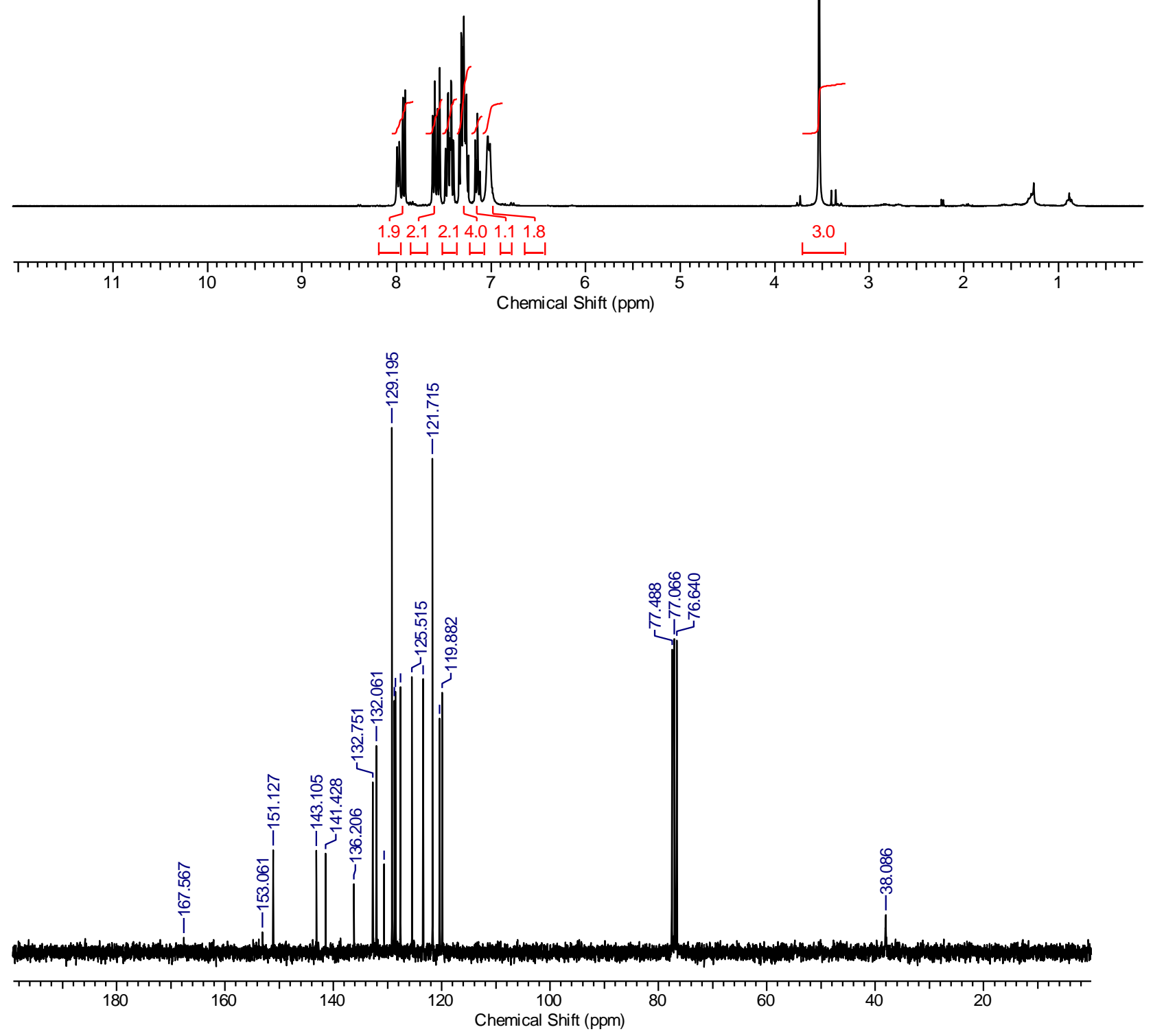

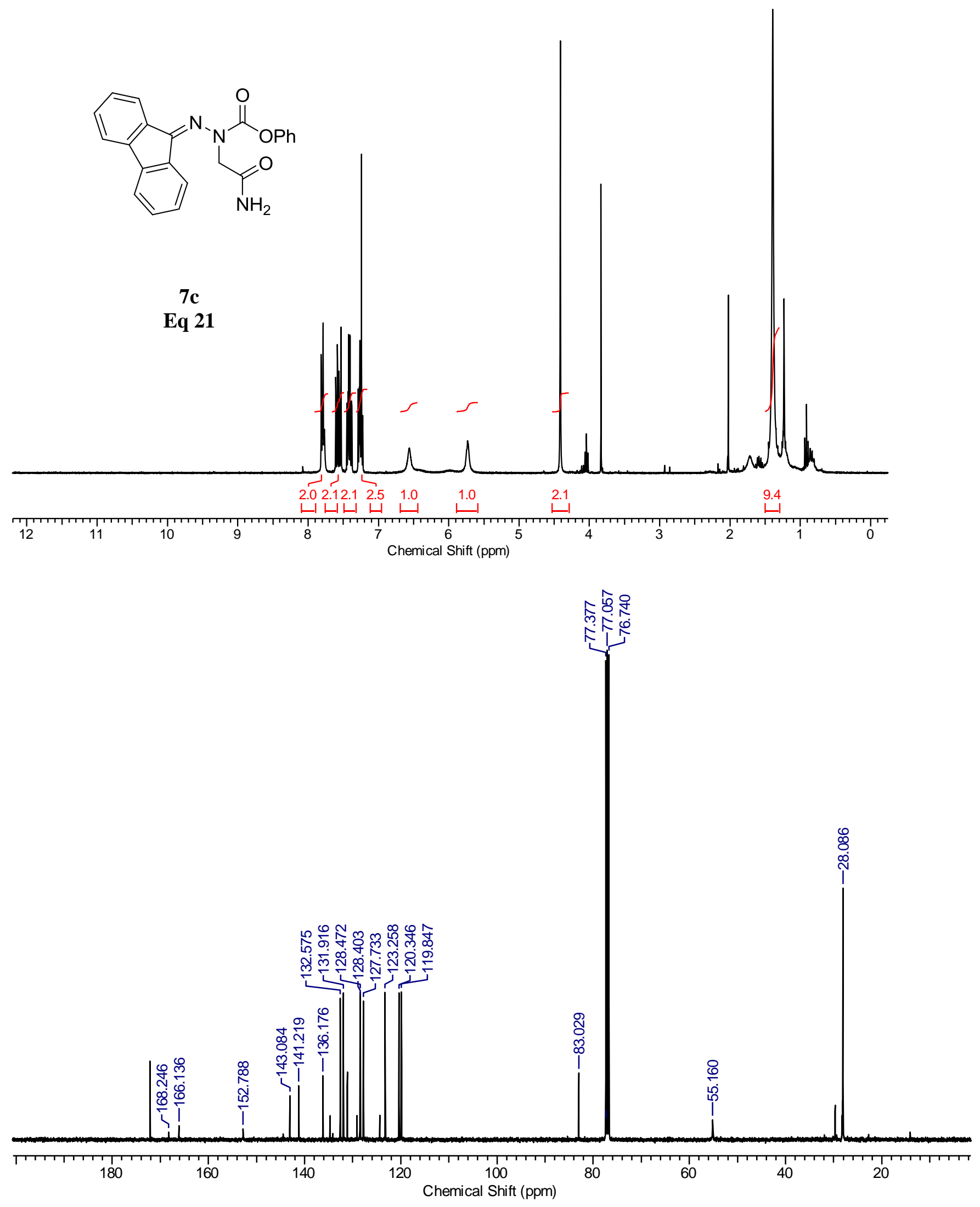


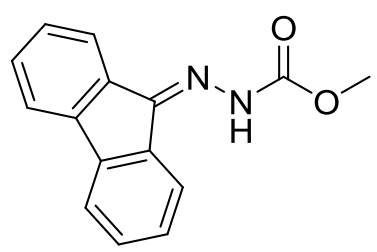

$1 \mathrm{k}$

Eq 20
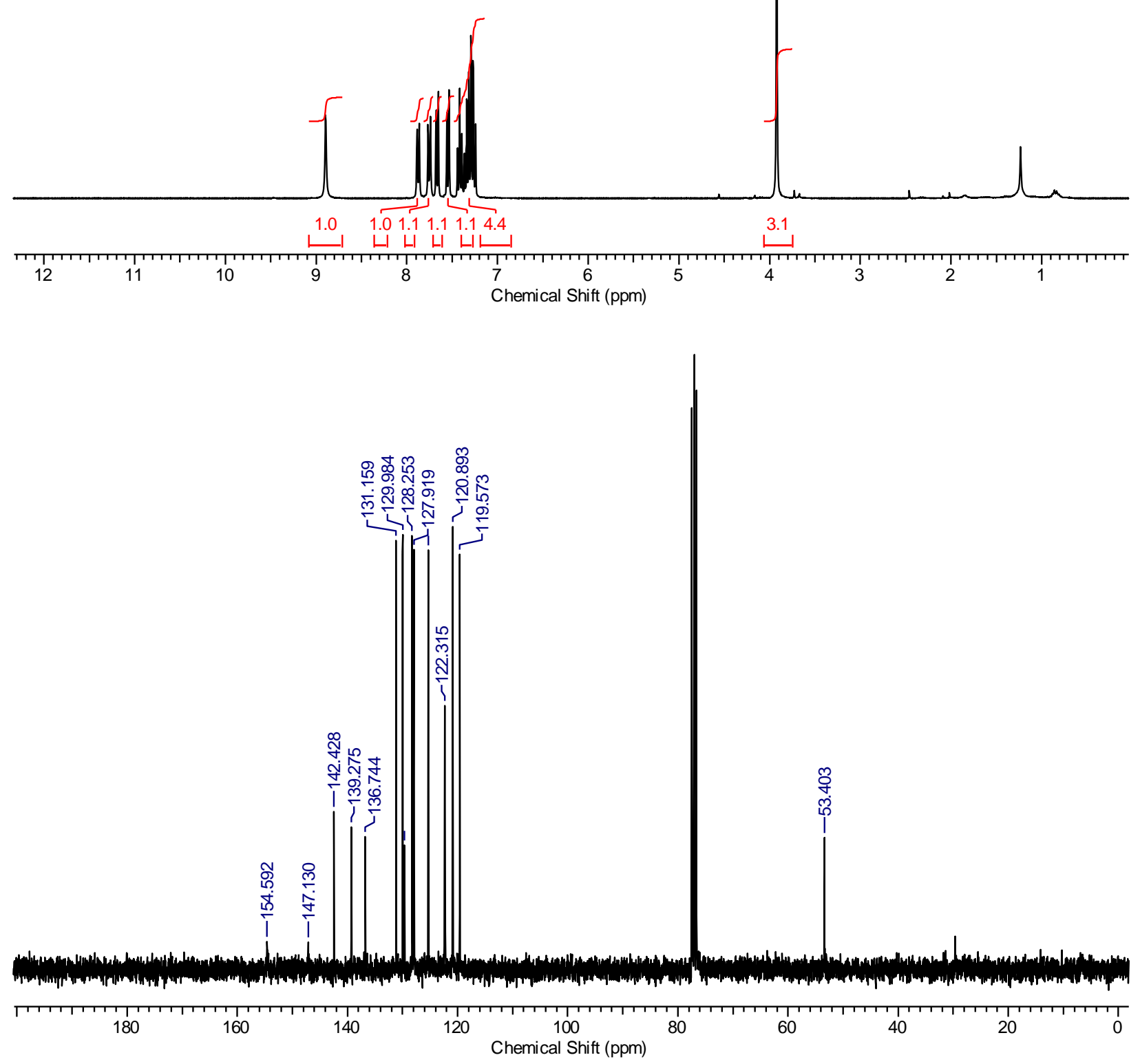